\title{
Uma visão estrutural sobre componentes do processo de adaptação metabólica de tumores.
}

\begin{abstract}
Tese apresentada ao Departamento de Física e Ciência Interdisciplinar do Instituto de Física de São Carlos, Universidade de São Paulo, de acordo com as normas do concurso público de títulos e provas para obtenção do título de Livre-Docente (EDITAL ATAc/IFSC-19/2017).
\end{abstract}

\section{Andre Luis Berteli Ambrosio}

Agosto de 2017 
Em branco. 


\section{Agradecimentos}

O ponto em comum ao longo de toda a minha trajetória, já há 16 anos, é a Sandra. Sem ela - sem sombra de dúvidas - eu não chegaria nem perto de onde estou hoje. Sua seriedade, determinação, perseverança, e principalmente, sua contagiante paixão pela descoberta científica, ainda hoje formam a bases de minhas decisões. Mesmo que pudesse realizar o controle negativo na minha vida, duvido que estaria melhor, e mais feliz, do que se eu não a tivesse encontrado.

Agradeço a todos com quem interagi e que, de uma maneira ou de outra, contribuíram para minha formação e trajetória. Agradecimento especial aos meus orientadores, coorientadores e supervisores, colaboradores, colegas e amigos de formação. Me espelho no que cada um tem de melhor.

Agradeço o LNBio e o CNPEM, na pessoa do Dr. Kleber Franchini, pela oportunidade e apoio incondicional, em todos os níveis; pelo suporte institucional, pelas inúmeras oportunidades de colaborações com meus colegas pesquisadores e pela liberdade e confiança nas decisões que dizem respeito ao andamento de nossa linha de pesquisa. Com certeza o LNBio é um lugar único no país para o desenvolvimento da ciência. Faço um agradecimento especial aos excelentes membros permanentes, principalmente à Alessandra Girasole. Muito obrigado aos alunos e aos pós-doutorandos que fazem ou fizeram parte do PMT desde 2009; todos sempre abraçaram nossas ideias como causa própria e são a força motriz da nossa linha de pesquisa.

Agradeço a FAPESP por todo o financiamento provido ao longo desses anos, na forma de Auxílios de Pesquisa e Bolsas.

Expresso minha enorme felicidade e gratidão à minha mãe, Sueli, ao meu pai, José Renato, e à minha irmã, Cíntia. Graças aos seus valores, sacrifícios e apoio, pude estudar e seguir o meu caminho.

Não menos importante, dedico este documento ao meu filho Bruno, o resultado mais importante da minha colaboração com Sandra. Bruno foi concebido em laboratório (literalmente), graças ao pioneirismo de Patrick Steptoe e Robert Edwards e da habilidade da equipe da Dra. Paula Navarro (FMRP, USP). Que Bruno cresça com o pensamento livre e seja justo e feliz.

"To a man with only a hammer, everything looks like a nail." - Mark Twain 
Em branco. 


\section{SUMÁRIO}

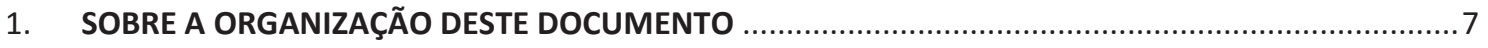

2. CONTEXTUALIZAÇÃO DO PROBLEMA BIOLÓGICO: O METABOLISMO TUMORAL ...........................8

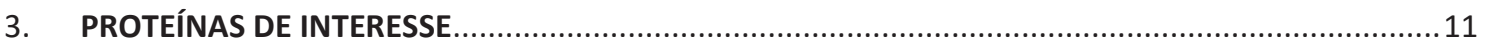

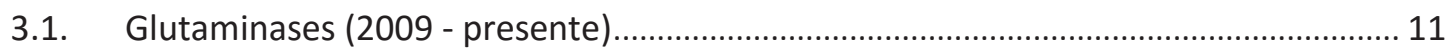

3.1.1. Contribuições do candidato na área. ................................................................ 17

3.2. Fatores de transcrição induzíveis por hipóxia, HIF (2011 - presente) .............................. 21

3.2.1. Contribuições do candidato na área. ...................................................................... 28

3.3. Carreador mitocondrial de piruvato, MPC (2013 - presente) .................................... 30

3.3.1. Contribuições do candidato na área. ...................................................................... 33

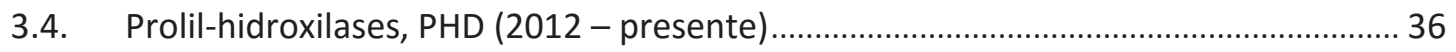

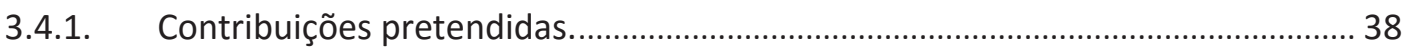

3.5. Canal ânion-seletivo dependente de voltagem 2, VDAC-2 (2016 - presente)............ 40

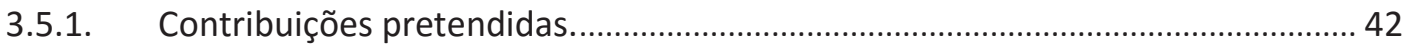

3.6. Fator de transcrição MondoA (2013 - presente) ........................................................... 43

3.6.1. Contribuições pretendidas........................................................................... 44

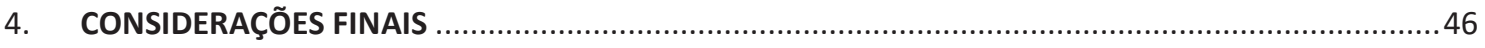

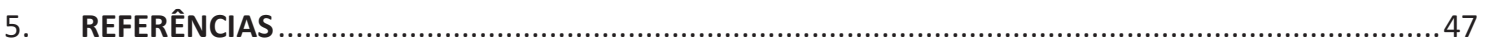


Em branco. 


\section{SOBRE A ORGANIZAÇÃO DESTE DOCUMENTO}

Quando da confecção desta tese, são praticamente 8 anos trabalhando como pesquisador independente no LNBio. Durante todo esse tempo, dividi, e ainda divido, a coordenação do laboratório de pesquisas multidisciplinares no assunto do processo de adaptação metabólica de tumores, com a Dra. Sandra Dias. O objetivo do nosso laboratório é contribuir para o entendimento das bases moleculares que permitem aos tumores suprir suas elevadas demandas por energia e blocos biossintéticos; estas demandas estão diretamente associadas às altas taxas de proliferação celular. Neste sentido, combinamos nossa experiência nas áreas de biologia estrutural, molecular e celular, visando sempre uma validação complementar das hipóteses levantadas. Obviamente, o objetivo máximo é o de contribuir com o desenvolvimento de novas e mais eficientes oportunidades terapêuticas, todavia, passando antes pela ciência básica.

Como já descrito em meu memorial circunstanciado, o tema da pesquisa e a aproximação multidisciplinar ao problema foram concebidos e herdados do trabalho desenvolvido durante meu pós-doutoramento nos Estados Unidos. Naquela ocasião, Sandra e eu presenciamos o renascimento do interesse da comunidade científica no metabolismo de tumores e participamos ativamente da descoberta da importância das enzimas glutaminase como potenciais alvos para o tratamento neste contexto.

Ao longo dos últimos anos, como pesquisador independente no LNBio, dentre vários outros trabalhos, contribui para a demonstração inédita de que a isoenzima GAC é a mais relevante glutaminase em câncer e também o principal alvo para a descoberta de novos fármacos. Também, nosso grupo foi o pioneiro em determinar as estruturas cristalográficas de todas as isoenzimas das glutaminase de mamíferos (GAC de camundongo e KGA e GLS2 humanas). Descrevemos um mecanismo molecular inédito de ativação e inibição alostérica destas dessas proteínas, que envolve a formação de filamentos. Para tanto, fizemos uso combinado de microscopia eletrônica de transmissão para a proposição de uma estrutura molecular.

Através da cristalografia, fomos os primeiros em identificar um ligante intracelular nãocovalente para a família dos fatores de transcrição HIF. HIF, que regula a expressão de mais de 5 \% do genoma humano, permite que tumores sobrevivam em condições de baixa disponibilidade de oxigênio e nutrientes. Por último, realizamos a inédita purificação do carreador mitocondrial de piruvato humano, juntamente com a confirmação de sua atividade autônoma em vesículas artificiais. Até o momento, este é o único trabalho que descreve produção recombinante e funcional desta classe de proteínas de membrana e abriu as portas para estudos estruturais.

Em vista do acima exposto, espero, através deste documento, demonstrar minha capacidade de produzir uma linha de pesquisa própria, coerente e continuada. Intrinsecamente associado a isso, está a captação de recursos perante a FAPESP e o exercício da docência, principalmente na área de pós-graduação, orientando dissertações e teses ( 6 concluídas e 2 em andamento), e supervisionando pós-doutores (1 concluída e 3 em andamento).

Compilo, portanto, cinco artigos dos quais sou autor de correspondências, já publicados em revistas internacionais indexadas, além de um outro manuscrito, em fase de revisão (Anexos I, II e III). Também, descrevo outros trabalhos em andamento, tão relevantes quanto, obviamente ainda dentro do tema do metabolismo tumoral. Estes são desenvolvidos juntamente com pesquisadores do Brasil, Estados Unidos e Reino Unido. A intenção é garantir a internacionalização de nossa pesquisa e também estar alinhado com as fronteiras tecnológicas voltadas para a biologia estrutural. Tenho plena conviç̧ão que estes trabalhos colaborativos renderão excelentes frutos em um futuro próximo. 


\section{CONTEXTUALIZAÇÃO DO PROBLEMA BIOLÓGICO: O METABOLISMO TUMORAL}

Tumor é um termo genérico, associado a um grupo de mais de 200 doenças que podem se desenvolver em praticamente qualquer parte do corpo humano. $O$ ponto em comum dessas doenças é que as células que as constituem, independentemente de sua origem, e em função de mudanças genéticas acumuladas, crescem e multiplicam de maneira anormal e descontrolada. À essa massa atípica de tecido é dado o nome de neoplasia.

Neoplasias (ou tumores) classificados como "benignos" são normalmente localizados e restritos ao órgão de origem, e respondem bem a tratamentos clínicos. Em casos mais graves, porém, células neoplásicas se desprendem da massa primária e podem ser levadas pela corrente sanguínea ou pelo sistema linfático a locais distantes de sua origem, onde formam novas colônias; este processo é chamado de metástase. Os tumores metastáticos são considerados "malignos" e comumente referidos como câncer.

Apesar das definições um tanto quanto simples, a variedade e a complexidade inerentes a essas doenças, do ponto de vista molecular, tornam extremamente desafiadores tanto o seu entendimento e caracterização, quanto a associação de uma terapia adequada. Neste sentido, em paralelo ao desenvolvimento de novas alternativas de diagnóstico e tratamento, grande parte dos esforços da comunidade científica estão voltados à determinação e organização dos mecanismos moleculares básicos de origem e propagação do câncer.

O câncer se desenvolve ao longo do tempo, à medida que alterações genéticas, epigenéticas e outras aberrações cromossomais se acumulam nas células. Além do mais, estas alterações devem ser positivamente selecionadas, do ponto de vista evolutivo e clonal. Tais características, que lenta e coletivamente transformam uma célula normal em pré-cancerosa e, em última instância, em câncer, são chamadas de "pilares da transformação celular" (1). São oito no total e encontram-se resumidos a seguir. Embora cada uma dessas marca de seleção contribua para o desenvolvimento da doença, não é até que uma célula exiba o conjunto completo (ou quase) de características, pode-se dizer que o câncer desenvolveu completamente.

i. Divisão celular autossuficiente. Células são organizadas em tecidos e os tecidos, por sua vez, em órgãos com funções específicas, como os pulmões, fígado, coração, cérebro e pele. As células de cada órgão devem se comunicar e funcionar coletivamente para o correto desenvolvimento e funcionamento do respectivo órgão. Quando o crescimento é necessário, as células coletivamente enviam sinais para outras células para serem divididas. Células de câncer, por outro lado, não se comportam como membros dessa "equipe". Eles controlam sua própria proliferação, produzindo os próprios sinais de crescimento, superativando receptores de sinal ou ativando oncogenes;

ii. Insensibilidade aos sinais de interrupção da divisão celular. Assim como existem sinais que estimulam a proliferação celular, existem sinais que a interrompem. As células cancerosas são capazes de interromper ou ignorar essas mensagens inibitórias. Normalmente, isso é resultado de mutações ou alterações em genes supressores de tumores, que normalmente controlam a resposta de uma célula a estímulos internos e externos de saída do ciclo de divisão celular;

iii. Resistência à morte celular programada. Quando as células ficam velhas ou são danificadas, estas são programadas para se autodestruir através de um processo controlado, chamado de apoptose. Esta é a forma do corpo de limitar o crescimento e descartar células com material genético comprometido, a fim de evitar a propagação de erros. Células cancerosas evitam o ciclo normal da morte celular e continuam a se acumular no corpo. Os sinais de apoptose podem ser interrompidos quando genes supressores de tumores sofrem mutações ou deixam de ser expressos; 
iv. Potencial replicativo ilimitado. $\mathrm{O}$ acúmulo de bilhões de células necessárias para a formação de um tumor requer divisão celular descontrolada, evitando apoptose e senescência replicativa. Na divisão celular normal, uma pequena porção do final de cada cromossomo, em uma região chamada telômero, é removida sempre que o DNA é copiado. Eventualmente, a perda de telômeros atinge um ponto crítico e a célula não pode mais dividir e replicar. Desta forma, células saudáveis autolimitam sua replicação, mas a ativação de uma enzima chamada telomerase pode manter telômeros e permitir que a célula continue a replicar indefinidamente. Mais de 90 $\%$ das células de câncer "imortalizadas" ativaram a telomerase, enquanto a maioria das células normais não o fazem (2).

v. Criação do próprio suprimento de sangue. $O$ crescimento tumoral requer um maior suprimento de sangue para fornecer oxigênio e nutrientes à massa celular acumulada. Um tumor é capaz de estimular a formação de novos vasos sanguíneos (angiogênese) e glóbulos vermelhos (eritropoiese), a partir da regulação de expressão gênica;

vi. Capacidade de invadir outros órgãos. Como mencionado acima, células cancerosas, ao contrário das células normais, podem romper as barreiras do tecido de origem e se espalhar de um órgão para o outro (metástase). Muitas vezes, as células fazem isso penetrando nos vasos sanguíneos recém-formados pelo próprio tumor;

vii. Evasão do sistema imunológico. Ao funcionar adequadamente, o sistema imunológico do corpo detecta e destrói células estranhas e anormais. Embora o processo não seja totalmente compreendido, há evidências de que as células cancerosas são capazes de evadir a destruição das defesas imunitárias do corpo até certo ponto, o que lhes permite proliferar e invadir outros tecidos.

viii. Reprogramação do metabolismo energético e biossintético. Mesmo com um aumento do suprimento de sangue, as células no interior de um tumor podem ser privadas de oxigênio e nutrientes. Isso seria prejudicial às células normais, que usam oxigênio para converter a glicose em energia através do processo de metabolismo aeróbio. As células cancerosas têm a capacidade de mudar o metabolismo de glicose aeróbico para anaeróbico (livre de oxigênio) (glicólise) para permitir que as células privadas de oxigênio continuem a produzir energia e a sobreviver. Todo um rearranjo das vias tradicionais de anabolismo e catabolismo se seguem.

Dentre todas as características brevemente descritas acima, o processo de adaptação metabólica de tumores constitui o tema principal de minha linha de pesquisa e, portanto, será abordado em mais detalhes a seguir.

Para realizar a divisão, uma célula qualquer deve duplicar seu genoma, proteínas e lipídios, ou seja, toda a sua biomassa, e montar esses elementos em células filhas. $O$ aumento das taxas de divisão celular no câncer exige que as vias metabólicas sejam quase que completamente redesenhadas e/ou adapatadas, quando comparadas com células normais proliferativas (3). As primeiras observações sobre as alterações metabólicas características de tumores, principalmente a elevada captação de glicose, foram feitas há quase um século pelo fisiologista alemão Otto Warburg (4), e Ihe renderam o Prêmio Nobel em Fisiologia de 1931. Porém, o campo do metabolismo do câncer tornou-se um tema de renovação interesse somente na última década.

Hoje em dia, é evidente que as alterações metabólicas associadas à tumorigênese abrangem todos os níveis conhecidos de interação entre a célula e os metabólitos (5). Primeiro, a célula transformada apresente uma capacidade aumentada de captar os nutrientes necessários. Em segundo lugar, células remodelam a forma como tais nutrientes, uma vez internalizados, são preferencialmente atribuídos a vias metabólicas. Por último, o metabolismo diferencial desses 
nutrientes exerce efeitos de longo alcance sobre o destino celular, entre os quais estão as alterações na diferenciação das próprias células cancerosas, bem como dos componentes do microambiente tumoral.

Dois nutrientes principais, absolutamente necessários pelas células em crescimento, são o carboidrato glicose e o aminoácido glutamina. Ambos fornecem um conjunto de intermediários de carbono para síntese de macromoléculas e garantem balanço dos níveis de agentes redutores utilizados na geração de ATP ou manutenção do equilíbrio redox (5).

A descoberta de que as células cancerosas utilizam excessivamente a glicose, mesmo na presença de oxigênio, é chamado de "efeito Warburg" (4). Á este efeito, também conhecido como "glicólise aeróbica", está associado uma presença elevada de proteínas de transporte de glicose (GLUT). Este é talvez um dos efeitos mais encontrados em câncer de maneira geral (6), e frequentemente associado à maus prognósticos (7-9). Múltiplos mecanismos e vias de sinalização promovem a absorção de aumentada glicose nas células cancerosas. $O$ fator de transcrição induzível por hipóxia, HIF, aumenta a expressão de GLUT e hexokinase, e a sinalização aberrante de PI3K/Akt aumenta a expressão especificamente de GLUT1 e a translocação dessa proteína para a membrana celular, assim como os oncogenes KRAS e BRAF $(5,6,10)$.

A alta demanda de células tumorais proliferativas por glutamina foi descrita pela primeira vez na década de 1950 pelo fisiologista americano Harry Eagle. Eagle demonstrou que o crescimento ótimo de células HeLa cultivadas requer um excesso molar de glutamina em meio de cultura de 10 a 100 vezes em relação a outros aminoácidos (11). No contexto metabólico, glutamina é talvez o nutriente mais versátil, podendo doar carbonos e nitrogênio para vias anabólicas e produção de energia (12). Possui também a capacidade de reabastecer os intermediários do ciclo TCA (anaplerose) e promover a síntese de nucleotídeos, proteínas e lipídio; além disso, está envolvida na sinalização celular e no controle de expressão gênica [146].

Basicamente, o envolvimento da célula tumoral no processo de adaptação metabólica é multifatorial. Vai desde a otimização da captação de nutrientes através das membranas, passando por rearranjos em seus metabolismos, em diferentes compartimentos, e terminando, muitas vezes, no núcleo, com efeitos diretos ou indiretos na expressão de genes, que outrora seriam fortemente regulados em células normais. Nesse contexto, os assuntos de interesse de meu grupo navegam por esses diferentes aspectos, associados a diferentes tipos de proteínas. Não necessariamente em ordem de incorporação do projeto, ou mesmo relevância, mas conduzimos pesquisa em: i) enzimas (glutaminases e prolil hidroxilases), ii) fatores de transcrição (HIF e MondoA) e iii) proteínas de membrana (Carreador mitocondrial de piruvato e porina VDAC2).

A seguir, apresento as bases contextuais e as nossas contribuições para o entendimento das estruturas e funções das proteínas acima. Os temas foram sendo incorporados de maneira lógica e coerente, e de acordo com oportunidades; todavia, sempre associados com uma percepção de originalidade e potencial de novidade das descobertas. Em paralelo, sempre vislumbrei também maneiras de aprender e incorporar em nosso grupo um conhecimento técnicoexperimental que seja compatível com a fronteira em biologia estrutural. 


\section{PROTEÍNAS DE INTERESSE}

\subsection{Glutaminases (2009 - presente)}

Glutaminases são enzimas que catalisam a hidrólise do aminoácido glutamina (Gln), produzindo glutamato (Glu), concomitante com a geração de um íon amônio. De maneira geral, a existência de múltiplas isoenzimas em mamíferos foi primeiramente demonstrada por Hans Krebs, com base na detecção de parâmetros cinéticos tecido-específicos e suscetibilidade a inibição pelo produto de catálise, enquanto testava a conversão de glutamina em glutamato em extratos teciduais de ratos (13). Até o momento, quatro isoformas de glutaminases já foram descritas em humanos, as quais são codificadas por dois genes distintos (Figura 1). As isoformas conhecidas coletivamente como GLS1, a Kidney-type glutaminase (KGA) e a Glutaminase C (GAC), são geradas por splicing alternativo do gene GLS (2q32.2). Em contraste, as isoformas GLS2, Liver-type glutaminase (LGA) e Glutaminase B (GAB), originam do gene GLS2 (12q13.3) através do uso alternativo de pontos de iniciação de transcrição e promotores (14).

Em células normais, a expressão de KGA é ubíqua, sendo encontrada em todos os tecidos com atividade de glutaminase com exceção do fígado $(15,16)$, apesar de ter sido reportada também em células endoteliais hepáticas (17). A variante GAC é predominantemente expressa em músculo cardíaco humano e pâncreas, ocorrendo também na placenta, rim e pulmão, porém, ausente no cérebro e fígado (18). Por sua vez, os transcritos derivados do gene GLS2 foram identificados também em tecidos extra hepáticos, como cérebro, pâncreas e células de câncer de mama (19), contrariando as descobertas anteriores de que sua expressão estaria restrita ao fígado adulto $(15,20)$.

Os dois genes parálogos que codificam para as glutaminases humanas supostamente se originaram a partir de um gene ancestral comum por duplicação seguida de evolução divergente $(21,22)$. O gene GLS humano tem $82 \mathrm{~kb}$ (quilobases) e se divide em 19 éxons (21) (Figura 1). 0 transcrito de KGA é composto por 18 éxons e formado pela junção dos éxons 1-14 e 16-19; o transcrito de GAC compreende apenas os 15 primeiros éxons $(18,21)$. O gene GLS2 humano tem comprimento de aproximadamente $18 \mathrm{~kb}$ e se divide em 18 éxons (22) (Figura 1). O transcrito canônico de GAB é formado pela junção de todos os 18 éxons do gene, enquanto que o éxon 1 está ausente no transcrito de $\operatorname{LGA}(14,20)$.

Embora localizados em cromossomos diferentes, os genes GLS e GLS2 humanos apresentam grau considerável de similaridade sequencial. Desconsiderando o éxon adicional presente em $G L S$, as principais diferenças entre as sequências codantes de ambos os genes se encontram nos éxons localizados nas extremidades dos genes. Por exemplo, os éxons 1 compartilham $62,5 \%$ de similaridade entre si, porém codificam para 129 aminoácidos em KGA e apenas 61 aminoácidos em GAB. Estas sequências codificadas pelo éxon inicial contém os sinais envolvidos no direcionamento mitocondrial e processos de translocação (Shapiro et al. 1991; Gómez-Fabre et al. 2000). Do mesmo modo, o éxon 19 de GLS e o éxon 18 de GLS2, que codificam para a região C-terminal de ambas, apresenta a menor similaridade sequencial $(29,4 \%)$. Foi demonstrado que esta região da proteína GAB está envolvida no reconhecimento de módulos de interação PDZ (Olalla et al. 2001), enquanto que em KGA, a porção equivalente sinaliza para ubiquitinição, via reconhecimento do motivo KEN (25). Nota-se que as diferenças mais significativas entre as regiões codantes de GLS e GLS2 compreendem motivos ou domínios envolvidos em direcionamento a organelas e interações proteína-proteína, o que pode explicar, pelo menos em parte, as diferenças de função e regulação. Por sua vez, os éxons 3-17 dos transcritos de 
mRNA de GLS e GLS2 tem o mesmo comprimento e apresentam alta similaridade sequencial $(78 \%)$.

Figura 1. Transcritos de mRNA dos genes humanos de glutaminases. (A) Gene GLS humano e transcritos alternativos KGA e GAC. (B) Gene GLS2 humano e transcritos alternativos GAB e LGA. Cada gene é representado com seus íntrons em linhas sólidas e éxons em caixas enumeradas. As regiões promotoras também são indicadas na extremidade $5^{\prime}$ de cada gene, incluindo o promotor alternativo do gene $G L S 2$ no íntron 1. Linhas rosas tracejadas indicam os éxons que formam os transcritos de KGA e GAB, e as linhas verdes escuras pontilhadas compreendem os éxons envolvidos na geração dos transcritos GAC e LGA. O sítio de início da transcrição é marcado por uma seta e enumerado como +1. Imagem adaptada de (26).

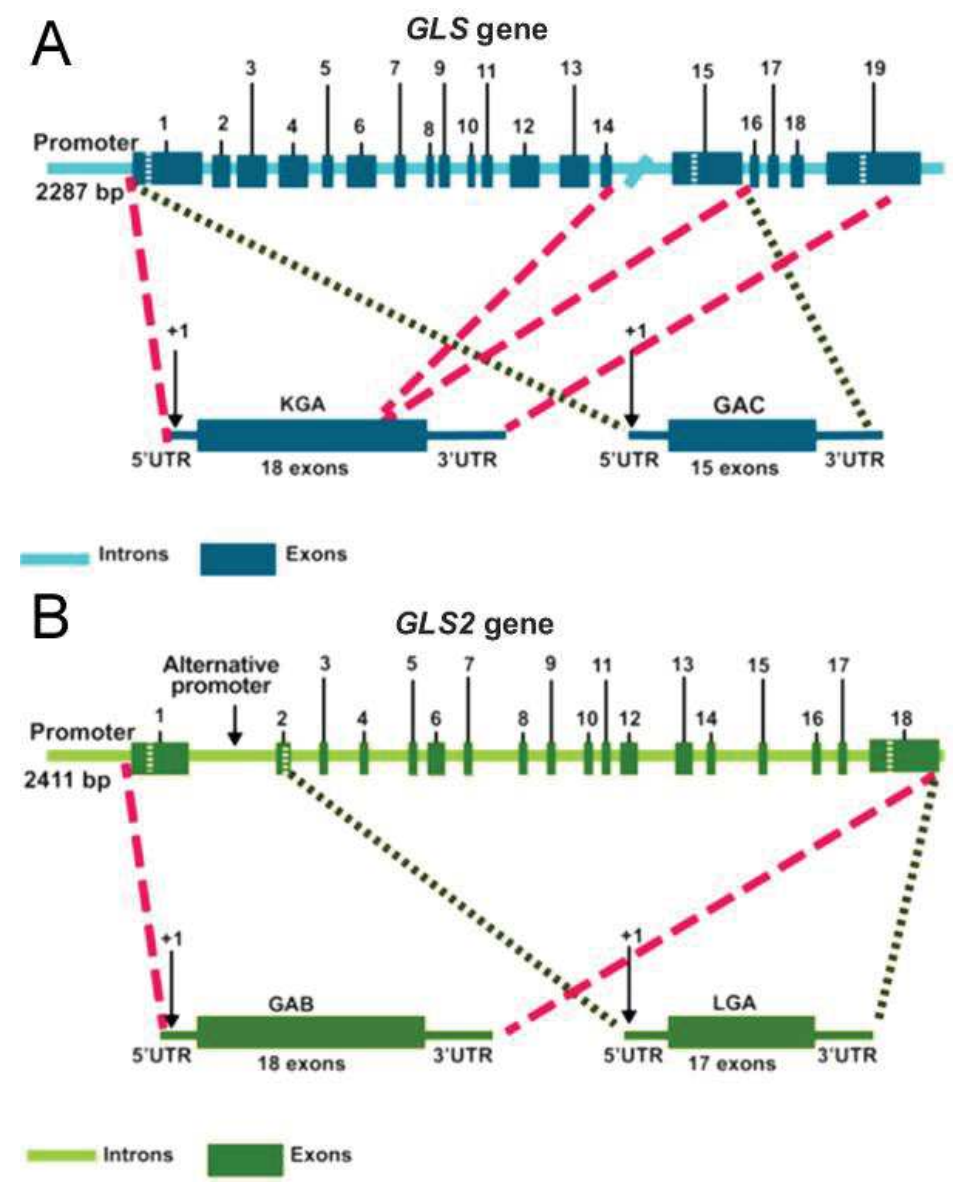

De maneira geral, desde bactérias até eucariotos, o domínio glutaminase canônico e autônomo consiste de uma estrutura globular compacta, tipicamente compreendida por aproximadamente 300 aminoácidos e dividida em dois subdomínios (27). Um dos subdomínios é inteiramente formado por $\alpha$-hélices, enquanto que o outro é misto, contendo tanto $\alpha$-hélices quanto folhas- $\beta$. Na junção entre os dois subdomínios é formado o bolsão catalítico, que abriga o resíduo de serina característico do sítio ativo (Figura 2). 


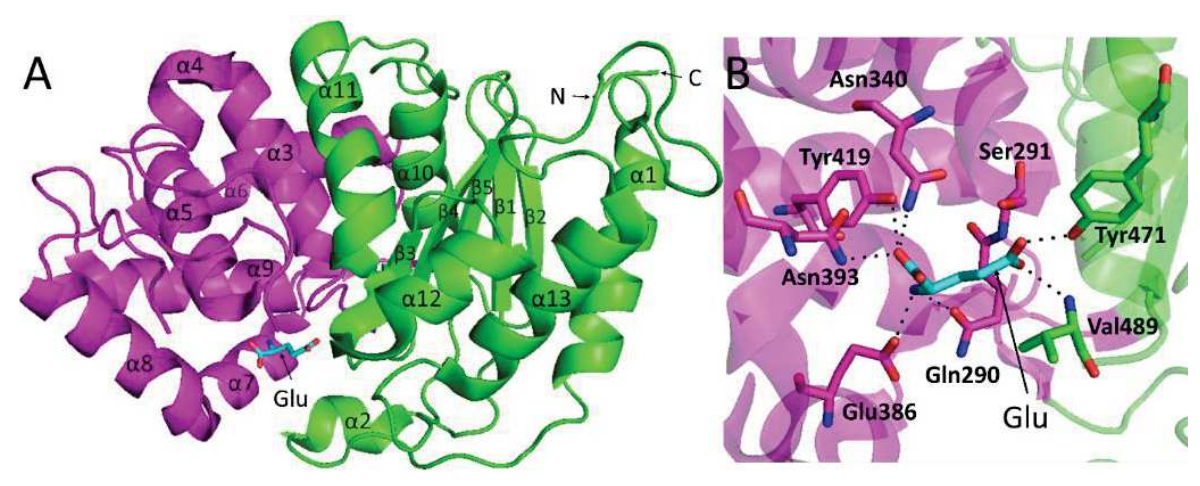

Figura 2. A estrutura do domínio glutaminase apresenta dois subdomínios e o sítio ativo está localizado na interface de ambos. (A) A estrutura cristalográfica de GAC de camundongo em complexo com glutamato (Glu) obtida por nosso grupo (PDB 3SS5) está representada em cartoon. O domínio I (Ile226-Pro286 e Cys429-Leu538, em verde) é composto por uma folha- $\beta$ de cinco cadeias antiparalelas $(\beta 2 \downarrow \beta 1 \uparrow \beta 5 \downarrow \beta 4 \uparrow \beta 3 \downarrow)$ cercada por seis $\alpha$-hélices e diversos loops. O domínio II (Phe287-Thr428, em magenta) consiste basicamente de sete $\alpha$-hélices. (B) L-Glutamato faz ligações de hidrogênio com os resíduos do sítio ativo; o grupamento amino da cadeia principal se liga a Glu386, Asn340, Tyr419 e Asn393; no ramo de cadeia lateral, a porção carboxila faz interações polares com Ser291, Tyr471 e o nitrogênio da cadeia principal de Val489.

Todavia, sabe-se atualmente que as glutaminases humanas são enzimas mais complexas em termos de arquitetura, possuindo estruturas com domínios adicionais flanqueando o domínio glutaminase, conforme representado na Figura 3.

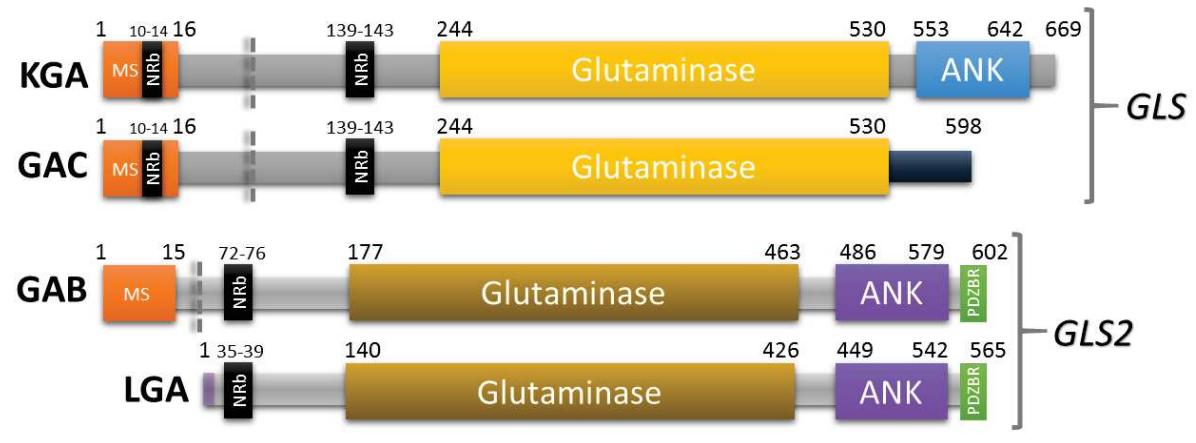

Figura 3. Representação dos multidomínios das glutaminases KGA, GAC, GAB e LGA, codificadas pelos genes GLS (2q32.2) e GLS2 (12q13.3). Os números indicam as posições na sequência primária de aminoácidos de cada proteína. A linha tracejada indica a região de processamento das glutaminases imediatamente após sua entrada na mitocôndria. MS: mitochondrial signaling sequence. $\mathrm{NRb}$ : nuclear receptor box (motivo $\mathrm{LXXLL}, \mathrm{L}=$ leucina e $\mathrm{X}=$ aminoácido qualquer). ANK: domínio formado por repetições de anquirina. PDZ-br: PDZ (PSD95\DIg\ZO1) binding region.

O comportamento cinético distinto das isoenzimas GLS e GLS2 é comumente utilizado para distinguir entre as isoformas de glutaminases humanas. As eficiências catalíticas das isoformas GLS são consideravelmente aumentadas na presença de fosfato inorgânico $\left(\mathrm{P}_{\mathrm{i}}\right)$, enquanto que o acúmulo do produto da catálise, Glu, causa inibição (Curthoys et al. 1976; Curthoys \& Watford 1995; Elgadi et al. 1999). Em constrate, ambas as isoformas GLS2 são insensíveis ao $P_{i}(29)$ e não apresentam inibição por Glu $(14,30)$. 
As principais diferenças cinéticas foram observadas em relação à dependência do ativador $\mathrm{P}_{\mathrm{i}}$, que é baixa para GLS2 e alta para GLS1; à relativa afinidade pelo substrato Gln, que é maior em GLS1 do que nas isoformas GLS2; e ao efeito inibitório de Glu, uma característica única reportada apenas para as isoenzimas $\operatorname{GLS1}(15,31)$. O mecanismo através do qual o $\mathrm{P}_{\mathrm{i}}$ ativa as enzimas GLS1 foi demonstrado por nosso grupo a partir de dados estruturais de cristalografia por difração de raios X da proteína GAC (29). O $P_{\mathrm{i}}$ se liga no interior do bolsão catalítico, resultando na estabilização alostérica dos tetrâmeros e facilitando a entrada do substrato por competir com o produto, Glu, garantindo a ciclagem da enzima. Esta competição de $P_{\mathrm{i}}$ versus Glu pela ligação ao sítio ativo explica a diminuição do efeito inibitório de Glu na presença de concentrações crescentes de $\mathrm{P}_{\mathrm{i}}(32)$.

Na presença de $\mathrm{P}_{\mathrm{i}}$, tanto KGA quanto GAC sofrem polimerização extensa e específica (3335). Além disso, o equilíbrio tetrâmero-dímero é dependente de concentração, conforme demonstrado para a isoforma $G A C$, a qual sofre polimerização mesmo na ausência de $P_{i}$, apenas elevando-se a concentração da enzima (35). Há uma correlação direta entre a tendência de oligomerização e os níveis de atividade das isoenzimas GLS1, sendo GAC a enzima mais ativa e com maior capacidade de se polimerizar. Deste modo, o inibidor GLS1-específico, BPTES [bis-2(5-phenylacetamido-1,2,4-thiadiazol-2-yl)ethyl sulfide], atua justamente de modo a prevenir a formação dos superoligômeros induzidos por $P_{i}(29,36)$. O mecanismo de inibição foi elucidado a partir de dados estruturais das isoformas GLS1 cristalizadas. A inibição por BPTES é alcançada através de um mecanismo não competitivo que interfere na ativação alostérica induzida por $P_{\mathrm{i}}$ : o domínio glutaminase de KGA humana forma um tetrâmero altamente simétrico contendo duas moléculas de BPTES que estão posicionadas nas interfaces dímero-dímero; a ligação do BPTES desencadeia uma mudança conformacional dos resíduos do sítio ativo e congela a enzima em um tetrâmero inativo estável $(35,37,38)$.

A estrutura multidomínios das glutaminases de mamíferos (Figura 3) é uma evidência da provável multifuncionalidade destas proteínas (26). Além do domínio catalítico, funcional e estruturalmente bem caracterizado, as glutaminases apresentam regiões $\mathrm{N}$ - e C-terminais contendo motivos e sequências que podem estar envolvidos em funções diversas. Os 15 primeiros aminoácidos localizados no $\mathrm{N}$-terminal das isoformas de glutaminase, com exceção da variante LGA, correspondem à sequência de sinalização mitocondrial. $O$ sítio de iniciação da transcrição e o promotor alternativo de LGA estão contidos no íntron 1 do gene GLS2, portanto, esta isoforma não contém o éxon 1 , onde se localiza o peptídeo sinal. De fato, análises de bioinformática da proteína LGA humana não encontraram uma sequência de sinalização mitocondrial no N-terminal, entretanto, um peptídeo sinal secretório foi predito para os 16 primeiros aminoácidos da proteína LGA transcrita a partir do segundo ATG (14).

Ainda na região $\mathrm{N}$-terminal, todas as quatro isoformas de glutaminase apresentam um motivo de interação com receptores nucleares (NR box, LXXLL): a sequência LEDLL nas isoformas GLS1 (resíduos 139 - 143) e LGDLL para GLS2 (resíduos 72 - 76 de GAB e 35 - 39 de LGA). A existência de resíduos carregados flanqueando motivos NR box parece contribuir para a afinidade da interação de coativadores com receptores nucleares (39), condição que também é atendida pelas glutaminases. Em GLS, existem lisinas localizadas a N-terminal (posições $130 \mathrm{e}$ 132 de GLS humana) e ácidos glutâmicos a C-terminal (posições 149 e 152 de GLS humana) do motivo NR box; em GLS2, há uma arginina a N-terminal (posição 71 de GAB humana) e dois ácidos glutâmicos a C-terminal (posições 82 e 85 de GAB humana) do motivo.

A partir do resíduo 76 de GLS humana, o $\mathrm{N}$-terminal se assemelha estruturalmente ao domínio EF-hand, formado por motivos do tipo hélice-loop-hélice, no qual o loop, usualmente formado por 12 resíduos, apresenta sítios de ligação a íons $\mathrm{Ca}^{2+}$. Domínios EF-hand estão presentes em proteínas como calmodulina (CaM, calcium-modulated protein), envolvida em sinalização celular (40), e troponina- $C$, importante componente da contração muscular esquelética e cardíaca (41). Proteínas contendo este domínio estão sujeitas a mudanças 
conformacionais cálcio-dependentes que expõem sítios de ligação a peptídeos alvos (42). Entretanto, apesar de sua conformação estrutural EF-hand-like, as glutaminases de mamíferos não apresentam os resíduos necessários para a coordenação dos íons $\mathrm{Ca}^{2+}(29)$. Portanto, até o momento, nenhuma função foi descrita para esta região.

Na porção central das glutaminases, encontra-se o domínio catalítico, que é altamente conservado desde bactérias até seres humanos (27), como já mencionado acima. Por sua vez, o C-terminal de glutaminases de mamíferos, com exceção de GAC, apresenta motivos conhecidos de interação proteína-proteína denominados repetições ANK (revisado no tópico 1.2 adiante). O C-terminal único de GAC, por sua vez, é formado por 47 resíduos e corresponde a uma região conformacionalmente heterogênea, que não pôde ser modelada nas análises estruturais de raios X (29). Até o momento, nenhuma função foi atribuída para a região C-terminal de GAC.

A região C-terminal de glutaminases mamíferas com exceção de GAC também apresenta motivos denominados KEN box, cujas letras representam a sequência de aminoácidos (lisina ácido glutâmico - asparagina) que o compõe. Os substratos do ciclossomo/complexo promotor de anáfase E3 ubiquitina ligase ligado à sua proteína ativadora Cdh1 (APC/C-Cdh1) são direcionados para degradação através de motivos de reconhecimento específicos, entre os quais, o KEN box (43). Foi demonstrado que GLS1 é substrato de APC/C-Cdh1 em linfócitos T proliferativos (25).

Conforme mencionado anteriormente, os últimos 4 aminoácidos da extremidade C-terminal de GAB humana, ESMV, correspondem a uma sequência consenso necessária para a interação com proteínas contendo domínio PDZ, um dos módulos mais comuns envolvidos em interações scaffolding, uma vez que se ligam às proteínas alvo e desencadeiam a formação de complexos funcionais específicos na membrana (44). Até o momento, foram identificadas duas proteínas contendo domínio PDZ e que são parceiras de interação de GAB: $\alpha$-1-sintrofina (SNT) e glutaminase-interacting protein (GIP) (24). Segundo Márquez et al. (2009), a hipótese de GLS2 cerebral sendo regulada por proteínas PDZ é atraente porque pode fornecer um mecanismo de controle tanto da síntese de glutamato quanto do direcionamento de glutaminase cerebral a compartimentos celulares extra-mitocondriais, como o núcleo, onde GLS2 já foi localizada (24).

Glutamina é o aminoácido mais abundante no plasma humano, perfazendo mais de $20 \%$ do pool de aminoácidos livres no sangue e $40 \%$ no músculo (46). A manutenção de altos níveis de Gln no sangue fornece uma fonte pronta de carbono e hidrogênio para biossíntese, energética e homeostase celulares que pode ser explorada por células tumorais para impulsionar 0 crescimento tumoral $(47,48)$. Após entrar nas células, Gln deve seguir entre dois caminhos: $(a)$ contribuir para a biossíntese de nucleotídeos e de uridina difosfato $\mathrm{N}$-acetilglicosamina (UDP-GIcNAc); (b) ser convertida a Glu pelas glutaminases (GLS ou GLS2) (Figura 4). Glu, por sua vez, pode contribuir para a síntese de glutationa e tem papel fundamental como precursor ou substrato para a síntese de vários aminoácidos, ácidos nucleicos, nucleotídeos e metabólitos (recentemente revisado em (49) (Figura 6). Portanto, o metabolismo de Gln é importante para o reabastecimento do reservatório de intermediários do ciclo do TCA (anaplerose), os quais são removidos da mitocôndria para participar das reações de biossíntese (cataplerose) (50). 


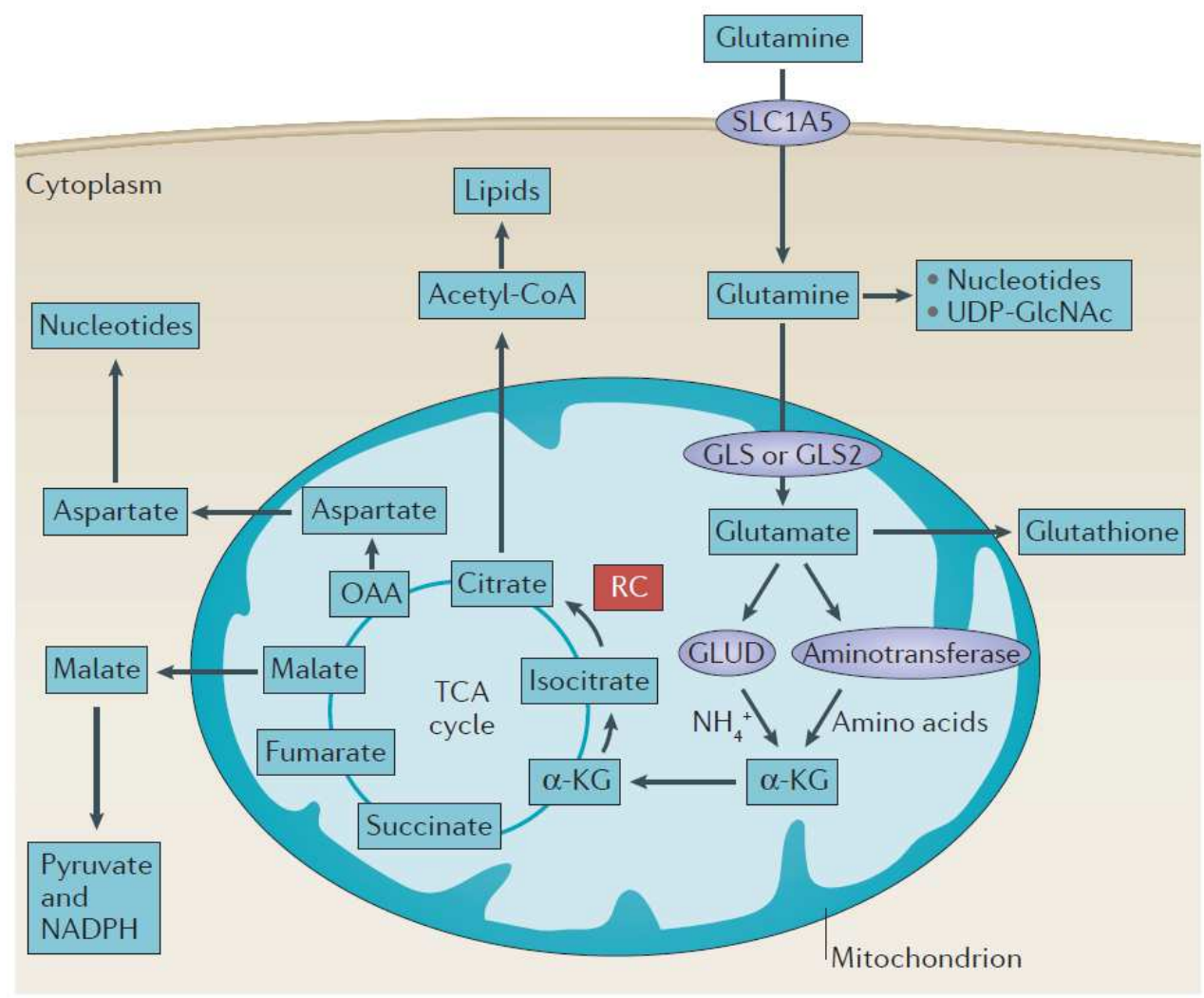

Figura 4. Principais destinos metabólicos e biossintéticos de Gln. Ao entrar na célula através de transportadores como SLC1A5, GIn pode ser utilizada na síntese de nucleotídeos e uridina difosfato N-acetilglicosamina (UDP-GIcNAc) ou ser convertida em Glu pelas glutaminases. Por sua vez, Glu contribui para a síntese de glutationa ou é convertido em $\alpha$-cetoglutarato ( $\alpha-K G$ ) através de duas enzimas diferentes: glutamato desi-drogenase (GLUD) ou aminotransferases, cujos subprodutos de catálise são, respectivamente, $\mathrm{NH}^{4+}$ e aminoácidos. $\alpha-\mathrm{KG}$ entra no ciclo do ácido tricarboxílico (TCA), o qual fornece elétrons para a cadeia transportadora da mitocôndria na geração de ATP através da geração de NADH e FADH 2 . Oxaloacetato (OAA) pode ser convertido em aspartato para a síntese de nucleotídeos. Alternativamente, $\alpha-K G$ pode ser usado na produção de acetil-CoA e lipídeos através do processo chamado de carboxilação redutiva (RC). Imagem retirada de (51).

A importância da glutaminólise para a manutenção do fenótipo maligno coloca as glutaminases na posição de alvos terapêuticos potenciais para o tratamento do câncer. A expressão de GAC, a isoforma GLS1 mais ativa, é aumentada em diversos tipos de câncer, sugerindo que o splicing alternativo do gene GLS contribua para um fluxo glutaminolítico mais elevado em câncer $(29,52-55)$. Por sua vez, GLS2 parece ter uma função mais complexa em câncer. GLS2 é induzida pelo supressor tumoral p53 e tem características supressoas de tumor contra gliomas, glioblastomas, câncer de pulmão e hepatocarcinomas, reduzindo proliferação, migração e formação de colônia in vitro $(29,52-59)$. GLS2 também exibe habilidades supressoras de tumor através da regulação negativa da sinalização por PI3K/AKT, sendo que a expressão de GLS2 foi associada com maior taxa de sobrevivência de pacientes HCC (hepatocarcinoma celular) (60). Um estudo recente mostrou que GLS2 sequestra a small GTPase Rac1 de modo a suprimir metástase (61). Além disso, foi demonstrado que GLS2 tem a função de inibir migração e invasão em células HCC via Dicer-miR-34a-Snail, a partir de sua interação direta com a proteína Dicer (62). A consequente estabilização de Dicer facilita a maturação de miR-34a que, por sua vez, reprime a expressão da proteína Snail, fator de transcrição envolvido em processos de transição epitélio-mesênquima $(\operatorname{EMT})(62,63)$. Entretanto, GLS2 parece apoiar crescimento e promover resistência a radiação ionizante em alguns tipos de câncer (64). 
Adicionalmente, GLS2 foi apontada como alvo crucial da oncoproteína N-Myc em neuroblastoma $(65,66)$.

Muitos oncogenes e supressores tumorais, tais como Myc (67), Ras (68), Rho GTPases (69), TGF $\beta$ (70), PTEN (71) e p53 (56), foram descritos como envolvidos no metabolismo de Gln glutaminase-dependente. Notavelmente, o fator de transcrição oncogênico Myc estimula a captação e degradação de GIn por GLS1 para sustentar a viabilidade celular e a anaplerose do ciclo de Krebs (67). Conhecido por regular miRNAs (72) e estimular proliferação celular (Eilers \& Eisenman 2008), Myc reprime a transcrição de miR-23a e miR-23b, resultando em expressão aumentada de seu alvo, GLS, e consequentemente, na regulação positiva do catabolismo de Gln (74). miRNAs desempenham papel central na regulação pós transcricional da expressão gênica ao anelar nas regiões $3^{\prime}$ não traduzidas dos mRNAs alvos para promover a degradação do transcrito ou a repressão de sua tradução (75). Similarmente, em células leucêmicas humanas cultivadas em Gln, o fator nuclear kappa B (NF-KB) p65 intensificou o metabolismo de Gln ao diminuir a expressão de miR-23a através de sua ligação direta ao promotor gênico (76).

Transformação dirigida pelo oncogene K-ras também mostrou induzir dependência a Gln para promover crescimento e sobrevivência $(68,77)$. Inibição do metabolismo de Gln pelo knockdown de GLS foi suficiente para comprometer crescimento de câncer dirigido por K-ras, indicando uma vulnerabilidade metabólica (78). Por sua vez, o fator de transcrição oncogênico c-Jun foi identificado como regulador primário da expressão de GLS em células de câncer de mama, sendo capaz de se ligar diretamente à região promotora do gene GLS e elevar a sua expressão (79).

\subsubsection{Contribuições do candidato na área.}

Meu primeiro contato com as glutaminases foi durante o pós-doutoramento no laboratório do Dr. Richard Cerione (Rick), na Cornell University. Naquela ocasião, em paralelo à descoberta realizada em seu grupo, a de que essa proteína era um inédito e potencial alvo em câncer, me foi dada a responsabilidade de produzir e purificar glutaminase em grandes quantidades - a partir de fonte recombinante - visando posteriores ensaios de ativação e inibição in vitro. Estes ensaios enzimáticos foram planejados para complementar a publicação original da descoberta (69).

Já se sabia da existência das múltiplas isoenzimas humanas, que seriam produzidas a partir de dois genes distintos, porém o número de publicações eram baixo. Todavia, começando então a estudar o assunto, percebi que havia uma grande e errônea simplificação das proteínas, a começar pela sua nomenclatura em artigos. KGA, ou Kiney-type Glutaminase, foi inicialmente isolada no início da década de 1970, em grande parte, pelos laboratórios dos doutores Norman Curthoys e Elling Kvamme. A outra proteína produzida pelo gene GLS, chamada de Glutaminase C, ou GAC, foi descrita pela primeira vez em 1999. Porém, ambas ainda eram coletiva e frequentemente ou chamadas de GLS1 em publicações, mesmo quando somente uma das duas proteínas era estudada. Inclusive, em um dos manuscritos seminais em metabolismo tumoral, publicado em 2008 pelo laboratório do Dr. Chi van Dang, a simplificação errônea foi mantida.

O trabalho desenvolvido no laboratório do Rick havia isolado GAC como alvo do inibidor 968. Todavia, eles possuíam somente o clone da KGA de rato para expressão recombinante em bactérias. Esse clone tinha sido gentilmente fornecido Curthoys. Realizei então a subclonagem de GAC de camundongo em vetor de expressão bacteriano, a partir de biblioteca de cDNA disponível no nosso laboratório.

Com sucesso, purifiquei tanto KGA, como GAC; os ensaios de atividade e inibição que se seguiram foram incorporados ao manuscrito (69). Como ainda não estava claro para nenhum de 
nós como fazer a correta distinção entre KGA e GAC, ao longo desse manuscrito ambas foram indiscriminadamente referidas como "isoformas de KGA".

Independentemente, após a conclusão do trabalho, todos estávamos automaticamente interessados em conhecer a estrutura cristalográfica do complexo GAC:968. Em 2008-2009, somente estava disponível no banco de dados PDB a estrutura do domínio glutaminase de GLS1, comum a KGA e GAC (PDB ID 3czd); lembrando que, como detalhado acima, estas são complexas proteínas multidomínios. Por meses, trabalhei incessantemente na cristalização de GAC e KGA completas e do domínio glutaminase comum à duas, visando obter a estrutura do complexo proteína:inibidor. Inicialmente, obtive inúmeros cristais do domínio glutaminase na presença de 968. Conjuntos de dados foram coletados nos CHESS (Cornell High-Energy Synchrotron Source). Todavia, nunca observamos a presença de 968 ligado à proteína, por meio da detecção de distribuição de densidade eletrônica característica.

Naquela época, consegui também cristalizar GAC na presença de 968 e coletar bons dados de difração no APS (Advanced Photon Source). Também, nunca observei a presença do inibidor ligado à proteína completa. Ainda, obtive cristais para KGA, porém, não foi possível coletar dados de difração além de 10 Å de resolução máxima.

Há décadas, se sabia que as glutaminases GLS1 (KGA e GAC) eram dependentes da presença de íons fosfato para completa ativação de suas atividades catalíticas sobre glutamina. Uma observação que fizemos quando dos ensaios de atividades para o manuscrito original, foi a de que GAC era muito mais ativa e eficiente que KGA sobre o substrato, mesmo com ambas dividindo sítios ativos idênticos e em condições análogas de fosfato. Porém, naquela ocasião, optamos por não incluir estas observações, por não estarem completamente caracterizadas. Foi nesse momento que encerrei meu pós-doutorado, para assumir a vaga de pesquisador independente no LNBio.

Já no Brasil, dedicando esforços para estabelecer as bases de meu laboratório, junto com a Sandra, foi natural a continuidade deste trabalho sobre as atividades catalíticas das glutaminase. Mais importante, estava claro para nós que GAC e KGA eram proteínas bem distintas, do ponto de vista enzimático, e mereciam ser caracterizadas como tais. Assim, nosso primeiro trabalho na área, como pesquisadores independentes, foi publicado na PNAS, no início de 2012. Neste trabalho, reportamos a clara e inédita distinção cinética entre GAC e KGA, também comparadas a LGA (uma das glutaminase expressas pelo gene GLS2), insensível a fosfato. Adicionalmente, demonstramos que GAC, especificamente, era a glutaminase mais adequada para suprir as elevadas demandas metabólicas em modelos agressivos de câncer de mama, e descrevemos a primeira estrutura cristalográfica de uma glutaminase contendo múltiplos domínios (29).

Ainda em 2011-2012, o mecanismo aceito para a ativação das glutaminases dependentes de fosfato, previamente estabelecido pelo Dr. Curthoys, envolvia uma transição de dímeros inativos para tetrâmeros ativos, quando na presença desse íon. Esse modelo de ativação foi tido como verdadeiro em nosso manuscrito original. Porém, ao estudarmos a fundo a transição oligomérica destas proteínas quando ativadas, percebemos que espécies bem maiores que tetrâmeros e heterogêneas em população, em termos de parâmetros hidrodinâmicos, estavam sendo formadas.

Foi então que conduzimos uma série de experimentos de microscopia eletrônica de transmissão (TEM) para avaliar visualmente a distribuição destas espécies oligoméricas. Estes estudos foram feitos em colaboração com o Dr. Rodrigo Portugal, do Laboratório Nacional de Nanotecnologia (LNNano), também no campus do CNPEM. Publicamos, em agosto de 2013, um inédito mecanismo de ativação para as glutaminases, baseado na formação de filamentos supratetraméricos (35). Mais ainda, demonstramos que a extensão do filamento estava diretamente relacionada aos níveis de atividade das diferentes isoenzimas. GAC, a glutaminase mais ativa, 
formava os filamentos mais longos. KGA e LGA, ambas possuindo domínios ANK C-terminal, formavam filamentos curtos, com pouca atividade (KGA), ou não formavam filamentos, também não respondendo a fosfato (LGA).

Em um momento anterior, havíamos nos encontrado com o Dr. Chi van Dang em um congresso internacional da área. Na ocasião, ele nos ofereceu amostras de um outro novo inibidor de glutaminase, chamado de BPTES, também desenvolvido pelo Dr. Curthoys. Chi nos propôs que fizéssemos a determinação do mecanismo de inibição, em nível molecular. Ainda neste manuscrito de 2013, na JBC, descrevemos que BPTES era um inibidor alostérico, que causava o rompimento dos filamentos, outrora ativos.

Em meados de 2012, como consequência da nossa publicação na PNAS, fomos procurados pelo médico geneticista George Calin, do MD Anderson Cancer Center, em Houston, TX. Dr. Calin vinha se dedicando a investigar mecanismos moleculares envolvidos no desenvolvimento de câncer colorretal e havia descoberto que nesse tipo de tumor era comum a superexpressão de um longo RNA não codificador (IncRNA) conhecido como CCAT2. Seu grupo havia observado, mais especificamente, que uma variante alélica de CCAT2, com uma base guanina (G) no lugar de timina (T), estava relacionada com risco aumentado de câncer colorretal. Ele notou ainda que a troca desse nucleotídeo gerava alterações metabólicas na célula e levantou a hipótese de que IncRNA seria um regulador de glutaminase.

Nosso encontro resultou em uma colaboração que envolveu pesquisadores de sete países: Brasil, Estados Unidos, Espanha, Holanda, Croácia, Itália e Romênia. Demonstramos, por meio de diversas técnicas, que a variante alélica $G$ de CCAT2 interage mais fortemente com um complexo proteico conhecido como CFIm, induzindo um aumento na expressão de GAC em detrimento da isoforma KGA; essa preferência por GAC favoreceria um maior consumo de glutamina pelas células tumorais, levando ao aumento da proliferação e metástase (55). De minha parte, contribui, junto com membros de meu grupo, para a produção das CFIm recombinante e estudos bioquímicos e biofísico de sua interação com CCTA2. Nossa colaboração com o Dr. Calin ainda continua ativa, agora com a submissão de novas propostas de pesquisa, todavia ainda dentro do assunto de IncRNA e câncer.

Um aspecto das glutaminase humanas que sempre nos intrigou, é o fato de que, como mencionado na sessão anterior, estas existem na forma de várias isoenzimas em humanos e todas são proteínas multidomínios. Uma linha de pesquisa derivada em nosso laboratório investiga a estrutura e função destes, e um manuscrito foi recentemente publicado em JBC (80). Basicamente, a filogenia dessas enzimas medicamente relevantes permanece desconhecida, levando-nos a investigar sua origem e evolução. Usando sequências de glutaminas procarióticas e eucarióticas, construímos uma árvore filogenética cuja topologia sugeriu que a arquitetura multidomínios foi herdada de antepassados bacterianos, provavelmente simultaneamente com a hospedagem do endossimbionte da proto-mitocôndria. Propusemos um modelo evolutivo em que o aparecimento da isoforma enzimaticamente mais ativa, GAC, que é expressa em diversos tipos de câncer, foi um evento de retrotransposição tardia que ocorreu em peixes da classe Chondrichthyes. As repetições de ankyrina (ANK) nas glutaminases foram adquiridas no início da sua evolução. Para obter informações sobre o enovelamento ANK, resolvemos duas estruturas cristalográficas de alta resolução das repetições de ANK de ambas as isoformas, de glutaminase GLS1 (KGA) e GLS2 (GAB e LGA). Descobrimos que ANK de glutaminase formam contatos intramoleculares únicos através de dois motivos altamente conservados; Curiosamente, esse arranjo oclui uma região geralmente envolvida em interações proteínaproteína mediadas por ANK. Também resolvemos a estrutura cristalográfica de KGA completa. Coletivamente, as estruturas explicam a capacidade comprometida dessas proteínas de se montar em filamentos supra-tetraméricos cataliticamente ativos, como mostrado anteriormente para GAC. 
Entre os meses de agosto de 2012 e janeiro de 2013, um aluno de mestrado sob minha orientação, trabalhando na caracterização cinética e determinação estrutural das isoenzimas GLS2, teve a oportunidade de realizar um estágio BEPE FAPESP no Structural Genomics Consortium (SGC), em Oxford, UK. Na ocasião, sob a orientação do Dr. Wyatt Yue, o aluno determinou a estrutura cristalográfica inédita do domínio glutaminase de GLS2, que está sendo descrita agora em um manuscrito em fase final de preparação em nosso grupo e que, de maneira inédita, estabelece esta proteína como um novo fator pró-tumoral em câncer de mama. Adicionalmente, esta interação de sucesso com o SGC abriu portas para novas colaborações e publicações com o laboratório do Dr. Yue, como será descrito em sessões posteriores.

De minha parte, essas pesquisas foram financiadas por três Auxílios Regulares FAPESP, sob minha responsabilidade: 2010/05003-0, 2012/14298-9 e 2014/20673-2. Uma dissertação de mestrado e duas teses de doutorado, sob minha orientação, foram concluídas. A lista das publicações que resultaram desta linha de pesquisa, até o momento, encontram-se a seguir. As versões completas dos manuscritos estão disponíveis nos Anexos I.1 a I.4.

Anexo I.1: Cassago, A., Ferreira, A. P. S., Ferreira, I. M., Fornezari, C., Gomes, E. R. M., Greene, K. S., Pereira, H. M., Garratt, R. C., Dias, S. M. G., and Ambrosio, A. L. B. (2012) Mitochondrial localization and structure-based phosphate activation mechanism of Glutaminase C with implications for cancer metabolism. Proc. Natl. Acad. Sci. 109, 10921097; Co-autor de correspondência.

Anexo I.2: Ferreira, A. P. S., Cassago, A., Goncalves, K. d. A., Dias, M. M., Adamoski, D., Ascencao, C. F. R., Honorato, R. V., de Oliveira, J. F., Ferreira, I. M., Fornezari, C., Bettini, J., Oliveira, P. S. L., Paes Leme, A. F., Portugal, R. V., Ambrosio, A. L. B., and Dias, S. M. G. (2013) Active Glutaminase C Self-assembles into a Supratetrameric Oligomer That Can Be Disrupted by an Allosteric Inhibitor. J. Biol. Chem. 288, 2800928020; Co-autor de correspondência.

Anexo I.3: Redis, R. S., Vela, L. E., Lu, W., Ferreira de Oliveira, J., Ivan, C., Rodriguez-Aguayo, C., Adamoski, D., Pasculli, B., Taguchi, A., Chen, Y., Fernandez, A. F., Valledor, L., Van Roosbroeck, K., Chang, S., Shah, M., Kinnebrew, G., Han, L., Atlasi, Y., Cheung, L. H., Huang, G. Y., Monroig, P., Ramirez, M. S., Catela Ivkovic, T., Van, L., Ling, H., Gafà, R., Kapitanovic, S., Lanza, G., Bankson, J. A., Huang, P., Lai, S. Y., Bast, R. C., Rosenblum, M. G., Radovich, M., Ivan, M., Bartholomeusz, G., Liang, H., Fraga, M. F., Widger, W. R., Hanash, S., Berindan-Neagoe, I., Lopez-Berestein, G., Ambrosio, A. L. B., Gomes Dias, S. M., and Calin, G. A. (2016) Allele-Specific Reprogramming of Cancer Metabolism by the Long Non-coding RNA CCAT2. Mol. Cell. 61, 520-534;

Anexo I.4: Pasquali, C. C., Islam, Z., Adamoski, D., Ferreira, I. M., Righeto, R. D., Bettini, J., Portugal, R. V., Yue, W. W., Gonzalez, A., Dias, S. M. G., and Ambrosio, A. L. B. (2017) The origin and evolution of human glutaminases and their atypical C-terminal ankyrin repeats. J. Biol. Chem. 292, 11572-11585; Co-autor de correspondência. 


\subsection{Fatores de transcrição induzíveis por hipóxia, HIF (2011 - presente)}

Células normais quiescentes captam glicose para produção de energia, precursores biossintéticos e poder redutor através de vias oxidativas, como a fosforilação oxidativa, o ciclo do ácido cítrico (também conhecido como ciclo de Krebs), e a via das pentoses fosfato, além da reciclagem de doadores de elétrons como NADH e NADPH. Em neoplasmas, no entanto, a proliferação acelerada tem sido associada a um fenômeno descrito como glicólise aeróbica. Neste caso, a maioria do carbono derivado do consumo da glicose é secretada na forma de lactato mesmo em situações de alta disponibilidade de oxigênio no microambiente celular. Este fenômeno foi observado pela primeira vez em meados da década de 20 pelo fisiologista alemão Otto Warburg, que atribuiu essa alta produção de lactato a um defeito incomum das mitocôndrias $(4,81,82)$. Posteriormente suas observações foram chamadas de $O$ "efeito Warburg", e já foi demonstrado em diversos tipos de câncer com taxas de glicólise 200 vezes maior do que em células normais, devido ao aumento concomitante na captação e metabolismo de glicose. Essa característica é explorada em exame clínico, que utiliza glicose marcada e permite a deteç̧ão de alguns tumores, a técnica é conhecida como do FDG-PET (83). O desenvolvimento do câncer está intrinsecamente associado a reprogramação do metabolismo energético através da regulação de genes responsáveis pelo transporte de glicose, bem como da via glicolítica, de tal maneira que esse fenômeno é hoje aceito como um dos pilares de transformação celular associada ao câncer (HANAHAN E WEINBERG, 2011).

O efeito da glicólise aeróbica é somente $5 \%$ eficiente em produção de ATP quando comparada com a fosforilação oxidativa, no entanto, deve-se considerar que a super-ativação desta via em células cancerosas em alto estado de proliferação e elevada captação de glicose em uma taxa glicolítica alta o suficiente, faz com que a porcentagem final de ATP produzida pela glicólise possa exceder à produzida pela via oxidativa e em contraste com a respiração mitocondrial, a geração de energia pela glicólise é independente da presença de oxigênio no ambiente celular, conferindo assim aos tumores a capacidade de sobrevivência e a possibilidade de migração para áreas hipóxicas.

Em relação a difusão do oxigênio dos vasos sanguíneos as células, isto ocorre em um limite entre 100-200 $\mu \mathrm{m}$ de distância para a adequada oxigenação celular. Em tumores, as células rapidamente se proliferam e alcançam uma alta densidade celular, as quais facilmente esgotam o suprimento de nutrientes e oxigênio a partir da vascularização normal, superando assim o alcance e a capacidade de irrigação sanguínea. Esse cenário é um evento muito comum no processo canceroso, e devido à alta densidade celular, rapidamente levam à condições de moderada à severa hipóxia. Diversos mecanismos adaptativos contra hipóxia foram desenvolvidos pelas células e organismos. Um dos exemplos que podemos citar, é o aumento da transcrição do gene da eritropoietina que regula a produção de glóbulos vermelhos e assim elevar a oxigenação sanguínea $(84,85)$.

A homeostase do oxigênio é um dos processos mais importantes a serem regulados, pois tanto o excesso como sua escassez podem levar à toxicidade através de estresse oxidativo ou da morte celular programada. Em resposta à manutenção da homeostase do oxigênio, ocorre o acúmulo nuclear do fator de transcrição HIF-1 (Hypoxia-induced factor 1), que medeia as respostas adaptativas às mudanças nos níveis de oxigênio em tecidos e exerce um papel chave nesse processo. HIF-1 foi inicialmente identificada a aproximadamente 25 anos, através de sua atividade de ligação à DNA em extratos nucleares que foram sujeitos a hipóxia (86), e sua síntese é regulada pela ativação da fosfatidilinositol 3 quinase (PI3K) e pela via da MAPK (Mitogenactivated protein kinase) (87).

Atualmente são conhecidos mais de 100 genes cuja expressão é controlada pela HIF-1. Isso corresponde a aproximadamente $5 \%$ do genoma e esses genes podem ser agrupados em grandes grupos funcionais, como por exemplo, HIF-1 é responsável pela transcrição dos genes 
relacionados a proliferação celular, sobrevivência celular, motilidade, metabolismo energético, formação de metástases, eritropoiese e angiogênese, remodelamento de matriz extracelular, regulação do $\mathrm{pH}$, apoptose entre outros $(87,88)$. A hipóxia é um forte sinal para angiogênese em tumores e um dos principais alvos diretos da HIF-1 é a transcrição do VEGF (Vascular Endothelial growth factor) que rapidamente pode expandir regiões pouco vascularizadas em tumores sólidos através do recrutamento de células endoteliais e estimular a sobrevivência e proliferação celular.

Uma via metabólica muito importante em processo canceroso é a via do metabolismo energético, da qual HIF regula muitos dos genes envolvidos nessa via coordenando então diversas etapas, das quais podemos citar o aumento dos transportadores de glicose 1 e 3 (GLUT), hexokinases 1 e 2 (HK), fosfofrutokinase (PFK), lactato-desidrogenase (LDH), fosfogliceratokinase 1 (PGK), glicose fosfato isomerase (PGI), piruvato kinase $M$, dentre muitos outros (8991). O aumento da expressão desses genes, leva diretamente ao aumento da captação e metabolismo de glicose, suprindo assim a elevada demanda energética de células em alto estado proliferativo.

Outros processos além da hipóxia podem levar a estabilização de HIF-1, uma delas são mutações em genes supressores de tumor como o von Hippel-Lindau impede que HIF seja degradada em condições de normoxia, o que leva a formação de tumores de células renais (RCC), cerebelo, retina, feocromocitoma, tumores pancreáticos de ilhotas e saco endolinfático (ELSTs). Outras mutações também levam a estabilidade de HIF, como os genes de p53, Rb, Bcl2, Myc, ARF e Ras. HIF pode ainda ser estabilizada e ativada por outros processos celular, por exemplo, através dos hormônios e citocinas inflamatórias, pela da via da PI3K/Akt, pela atividade das quinases dependentes de ciclina (CDKs) levando a aumento da expressão ou degradação lisossomal de HIF e através da regulação de micro-RNAs levando ao aumento ou redução da sua expressão, como miR-20b que suprime a HIF-1 $\alpha$ em células de osteossarcoma e portanto, baixos níveis de miR-20b levam ao estímulo e atividade de $\operatorname{HIF}(84,92)$.

De modo geral, independente se HIF é regulada em condições de hipóxia ou através de outros processos celulares, é irrefutável que o controle da expressão de tantos genes por HIF-1 é considerado o exemplo mais extenso de controle metabólico coordenado em nível transcricional já descrito em qualquer organismo (93). Desta forma, a presença de HIF-1 é sempre associada com mau prognóstico e altos níveis de mortalidade de pacientes com câncer, à resistência a radio e quimioterapias, ao aumento do potencial metastático e recentemente foi tida como um dos cinco marcadores para análise de imuno-histoquímica para câncer de mama $(84,85)$.

HIF-1 é expressa em todos os tipos celulares e funcionalmente é um heterodímero composto das subunidades HIF-1 $\alpha$ (Homo sapiens, 826 aminoácidos) e HIF-1 $\beta$ também conhecida como ARNT (Aryl Hydrocarbon Receptor Nuclear Translocator) (Homo sapiens, 789 aminoácidos), pertencentes à família de fatores de transcrição bHLH-PAS (basic Helix-Loop-Helix $P A S)$ que se ligam à elementos responsivos, $\mathrm{HRE}$, em genes alvo, cuja sequência consenso é $5^{\prime}-$ RCGTG - 3' (onde R pode ser A ou G).

A subunidade HIF-1 $\alpha$ tem uma meia-vida de aproximadamente 5 minutos e é altamente regulada pela tensão intracelular de oxigênio (94). A regulação direta da estabilidade e a ativação de HIF-1 se dá principalmente por modificações pós-traducionais, onde a hidroxilação das prolinas 402 e 564 pelas prolil hidroxilases (PHDs) leva à rápida degradação de HIF através da degradação proteossomal. Além disso a hidroxilação do resíduo de asparagina 803 pelo fator FIH (inhibitor HIF1) resulta na inabilidade de HIF ligar-se a proteínas transativadoras. O resumo do mecanismo de regulação da HIF-1 $\alpha$ em condições de normoxia e sua atividade em condições hipóxicas é ilustrado na figura 5 abaixo. 


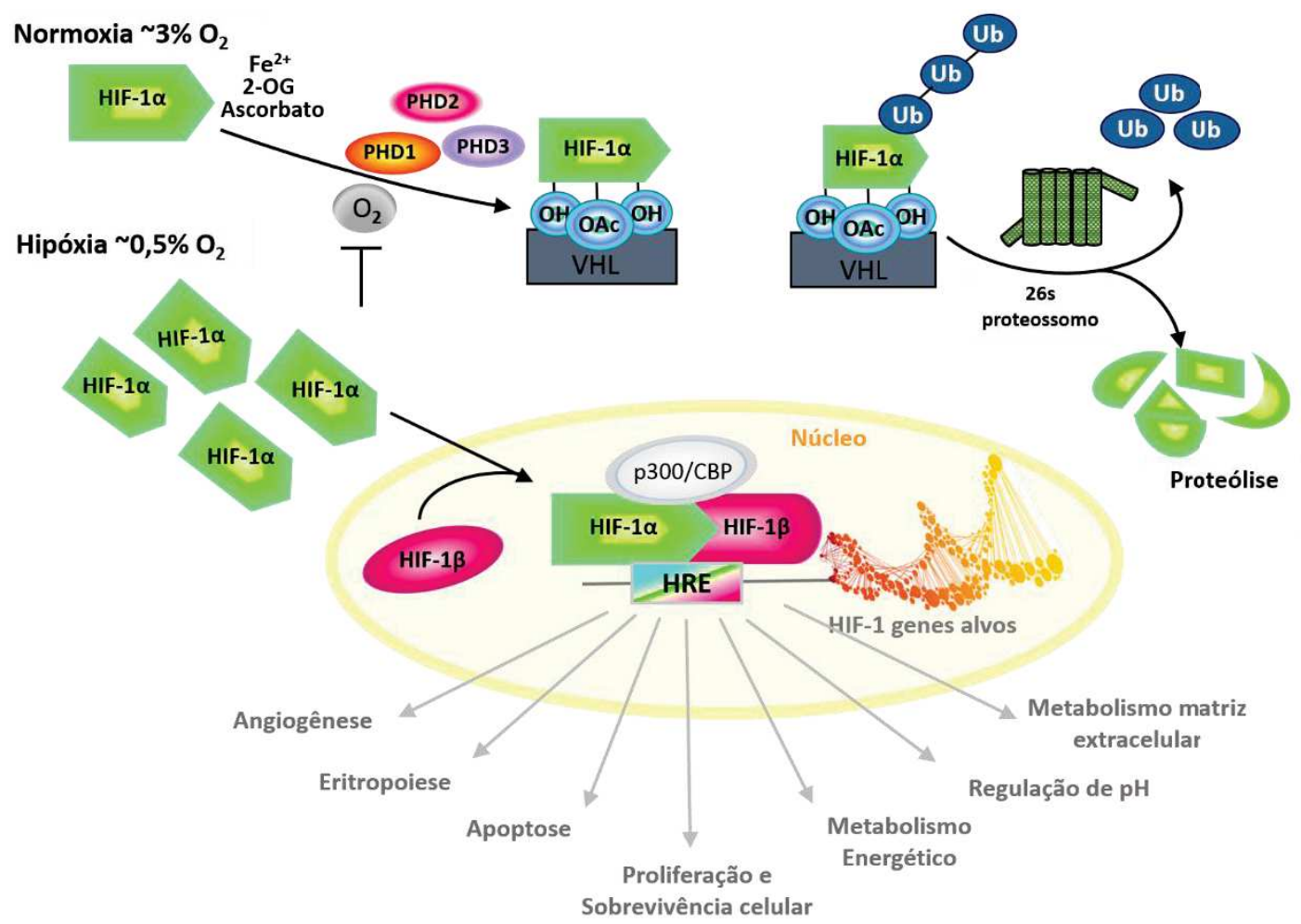

Figura 5. Mecanismo de regulação da HIF-1 $\alpha$ e sua atividade. Em condições de normoxia (parte superior), HIF sofre regulação pós traducional através da hidroxilação de dois resíduos de prolina, seguido de reconhecimento do complexo VHL destinando-a a degradação pelo 26s proteossomo. Na parte inferior da figura observamos o mecanismo de atividade da HIF em condições de hipóxia, onde a prolil-hidroxilação é inibida pela ausência de oxigênio e a subunidade $\alpha$ das HIFs irá se heterodimerizar com HIF-1 $\beta$, o complexo no núcleo reconhece os genes que contêm os elementos responsivos a hipóxia (HRE), o que levará a transcrição de mais de 100 genes no genoma. Imagem adaptada de https://research.medicine.umich.edu/office-research/biomedical-research-corefacilities/dna-sequencing e http://www.expertreviews.org/.

Ao todo, são conhecidos três genes distintos que codificam para subunidades $\alpha$ : HIF-1 $\alpha$, contendo 826 aa, HIF-2 $\alpha$, contendo 870 aa e HIF-3 $\alpha$ com 669 aa, sendo as HIF- $1 \alpha$ e $-2 \alpha$ as mais estudadas. Todas possuem semelhanças na organização estrutural quanto aos seus domínios funcionais, detalhados a seguir, além do domínio de interação com DNA (bHLH). As HIF apresentam dois domínios do tipo PAS (família Per-ARNT-Sim), chamados de PASa (mais próxima da região $\mathrm{N}$-terminal) e PASb; estes domínios são amplamente encontrados em proteínas envolvidas na transmissão de sinal, funcionando como módulo sensorial da tensão de oxigênio, potencial redox ou intensidade de luz, já identificado em mais de 2000 proteínas entre os mais diversos organismos. Demonstrou-se ainda esse domínio como sendo um elemento de interação proteína-proteína (95).

Uma peculiaridade das subunidades $\alpha$ é a presença do domínio de degradação dependente de oxigênio (ODDD), onde estão os resíduos de prolina que em condições de normoxia serão hidroxilados por uma família de proteínas conhecida como Prolil-hidroxilases (PHDs), a prolil-hidroxilação levará então a ubiquitinação de HIF- $\alpha$ pela proteína supressora de tumor pVHL (von Hippel-Lindal) e posteriormente ocorre a interação com o complexo da E3 ubiquitina ligase destinando então as subunidades $\alpha$ para degradação através do complexo proteossomal 26s(96). 
As subunidades 1 e 2 apresentam ainda dois domínios de transativação (estímulo da transcrição), designados NTAD (na porção n-terminal) e CTAD (na porção c-terminal), além de sequências consenso de sinalização nuclear (NLS). Apenas NTAD é encontrado na subunidade 3. Apesar da alta conservação de domínios funcionais, HIF-1 $\alpha$ compartilha apenas $43 \%$ e $36 \%$ de identidade sequencial com HIF- $2 \alpha$ e HIF-3 $\alpha$, respectivamente enquanto HIF- $2 \alpha$ e HIF-3 $\alpha$ são apenas $37 \%$ idênticas. A subunidade HIF-1 3 (789 aa, em média $30 \%$ idêntica à subunidades $\alpha$ ) é compreendida pelos domínios bHLH, PASa, PASb e possui somente um domínio de transativação C-terminal, CTAD. Todas as características estruturais das três subunidades $\alpha$, como descritas acima, estão ilustradas na Figura 6.

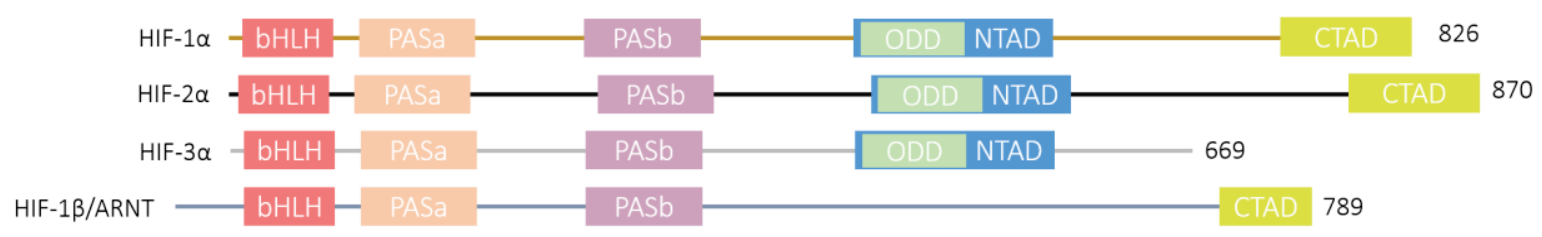

Figura 6. Representação esquemática da estrutura dos domínios que constituem as isoformas $-\alpha$ da HIF em humano. Os domínios de importância funcional estão representados da seguinte forma: bHLH - domínio hélice-loop-hélice básico de ligação à sequências consenso HRE, PAS - domínio de homologia Per-ARNT-Sim com repetições internas a e b, ODD - domínio de degradação dependente de oxigênio, TAD - domínios de transativação N- e C- terminais respectivamente. Sequências de sinalização nuclear, NLS, são encontradas nas subunidades $1 \alpha$ e $2 \alpha$. Adaptado de: Costa,M. e Ke,Q. Molecular Pharmacology, 2006.

O mecanismo de ativação da HIF-1 $\alpha$, além de requerer a heterodimerização com a subunidade $-\beta$, requer a interação com proteínas co-ativadoras diversas, como CBP/p300, SRC1 (Steroid Receptor Coactivator-1), Smad3 (Mothers against decapentaplegic homolog 3), HNF4 (Hepatocyte Nuclear Factor 4), AP-1 (Activator protein-1), Tie-2 (V-ets erythroblastosis virus E26 oncogene homolog 1) (97). Esta interação ocorre através do domínio C-TAD, que em particular, foi demonstrada como essencial para ativar a transcrição de genes específicos regulados por HIF-1 (98).

A subunidade HIF-2 $\alpha$ ativa a transcrição de um grande número de genes, dentre os quais vários são igualmente regulados por HIF-1 $1 \alpha$. No entanto, alguns deles são expressos somente pela HIF-2 $\alpha$, como o gene da EPO (eritropoietina), TGFA (fator de crescimento) e ANGPT2 (relacionado ao remodelamento de vasos sanguíneos) (99). Keith et al., 2012, observaram em modelos animais que, quando silenciado o gene da HIF- $2 \alpha$, ocorreu o crescimento e progressão tumoral. Isso indica que HIF-1 $\alpha$ e HIF-2 $\alpha$, desempenham papeis diferentes no desenvolvimento e progressão do câncer $(99,100)$.

Diferentemente de HIF-1 $\alpha$ e HIF- $2 \alpha$, a subunidade HIF-3 $\alpha$ é um pouco restrita quanto a expressão, comumente presente em cérebro, cerebelo, coração, pulmão, rim e músculo esquelético $(101,102)$. HIF-3 $\alpha$ foi a última subunidade a ser identificada, em 1998, e é capaz de heterodimerização com a HIF- $\beta$ em humanos e o complexo formado também se liga aos HREs. Recentemente em células de hepatoma, HIF-3 $\alpha$ foi caracterizada por retardar o aumento celular, reduzir a vascularização e por romper o complexo formado entre HIF-1 $\alpha$-ARNT-DNA $(101,103)$. Não temos conhecimento de estudos que correlacionam as subunidades $-3 \alpha$ e $-2 \alpha$ em termos de antagonização ou amplificação de função transcricional. 
A subunidade $-\beta$ da HIF-1 é normalmente encontrada em todos os tecidos, tanto em situações de normoxia quanto em hipóxia. Em condições normais de oxigênio (normoxia), ela está envolvida com a regulação do metabolismo de agentes xenobióticos, neste caso formando um complexo com a proteína AhR (Aryl hydrocarbon Receptor) (104-106). Já em condições de hipóxia, se complexa com as subunidades $\alpha$ da HIF e atuam na transcrição dos genes já mencionados acima.

Das três subunidades $\alpha$ da HIF, $3 \alpha$ foi a última delas a ser identificada e é distinta das demais em diversas sentidos. Por exemplo, o gene que codifica para HIF-3 $\alpha$ é regulado por HIF$1 \alpha$ e não por HIF-2 $\alpha$, onde apresenta seu ápice de expressão entre 8 à 16 horas em hipóxia, enquanto HIF-1 $\alpha$ tem seu ápice de expressão entre 4 à 8 horas $(102,107,108)$. Em sua sequência de aminoácidos, HIF-3 $\alpha$ apresenta somente uma prolina (P492) que é hidroxilada pelas PHD's, e posteriormente levam a ligação ao pVHL ao contrário das demais HIFs que são hidroxiladas em dois resíduos de prolina. HIF-3 $\alpha$ é encontrada no citoplasma e no núcleo sobre condições de normoxia, o que índica que somente a hidroxilação de uma prolina não seja suficiente para levar a sua degradação via proteossomo $(108,109)$. HIF-3 $\alpha$ é a menor das subunidades devido à ausência da região do CTAD, o que a impede a atividade de transativação com proteínas como $\mathrm{p} 300$, que é essencial para a atividade transcricional. A organização do gene da HIF3 $\alpha$ consiste de 19 éxons e três posições alternativas para início da transcrição são localizados nos exons 1a, 1b e 1c e, desta forma é exclusivamente suscetível a regulação pós traducional (109). São preditas 10 isoformas de splicing alternativo das quais seis delas foram confirmadas em nível proteico, sendo a IPAS (inhibitory PAS domain protein) a primeira isoforma identificada em camundongo, e seu homologo em humano é chamado de HIF-3a4. Além de IPAS, outras cinco isoformas variantes de splicing foram identificadas para HIF-3 $\alpha$, sendo referidas como HIF-3 $\alpha 1$, HIF-3 $3 \alpha 3$, HIF-3 35 , HIF-3 $\alpha 7$ e HIF-3 $\alpha 9$ e esta última sendo a mais longa de todas com 669 aa diferindo da isoforma $3 \alpha 1$ por alguns aminoácidos presente no $\mathrm{N}$-terminal (108). A única região comum entre todos splicings é o domínio PASb e, de forma geral as isoformas $-3 \alpha$ diferem grandemente no $\mathrm{N}$ - e no C-terminal, onde ocorre a perda parcial ou total no domínio bHLH $(109,110)$. Enquanto outras sofrem perda total ou parcial do C-Terminal incluindo o ODD e NTAD (-3a4). A Figura 7 abaixo ilustra os domínios presentes em cada isoforma, indicando a posição onde ocorrem variações devido aos splicings, em amarelo.

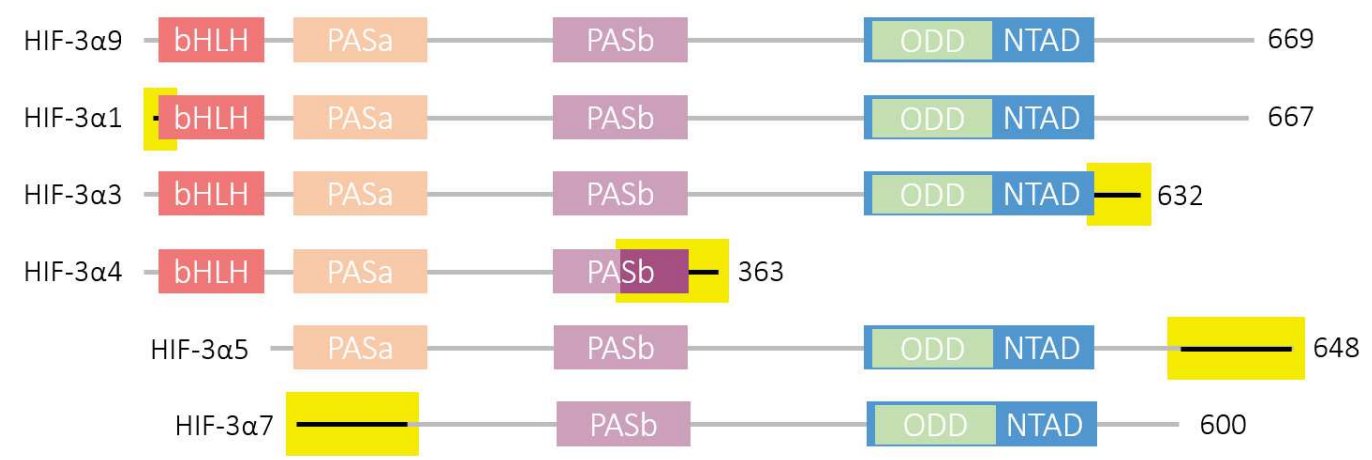

Figura 7. Representação esquemática dos domínios que constituem HIF-3a e suas variantes por splicing ou uso de promotores alternativos (os locais de ambos eventos são marcados em amarelo). Adaptado de (107). Os splicings contêm os domínios bHLH domínio hélice-loop-hélice básico, PAS - domínio de homologia Per-ARNT-Sim com repetições internas 1 e 2, PAC - região associada aos Pas2 (PASb = PAS2 + PAC), ODD domínio de degradação dependente de oxigênio, NTAD - domínios de transativação Nterminal. A isoformas 1 é tida como a isoformas canônica, em termos de numeração e composição. Todas as variações em regiões especificam geradas por splicing alternativo, que determinam as outras isoformas, são circundadas em amarelo. 
Quanto à sua expressão, varia de acordo com célula e tecido específico, em humanos seus transcritos estão presentes em diversos tecidos como coração, cérebro, placenta, fígado, rim, pulmão, pâncreas, músculo esquelético e cartilagem em diferentes padrões (108). Em câncer, sua expressão foi reportada em linhagens celulares de Ad4 e Caki-1 (rim), SKOV-3 (ovário), HeLa (útero), DU45 (próstata), MSTO e MTT (mesotelioma) e A549 (pulmão) (108-110).

A isoforma $3 a 4$ sofre um splicing na metade do domínio PASb acarretando uma mudança de $50 \%$ da sequência de aminoácidos quando comparada com as outras isoformas. Ela é também a melhor caracterizada das isoformas de splicing, e sua atividade é sempre reportada como sendo um regulador negativo das demais subunidades alpha das HIFs. Em camundongos é mais expressa em células purkinje no cerebelo e no epitélio da córnea. Sua expressão na córnea correlata com o fato dela interagir diretamente com HIF-1 $\alpha$ e HIF- $\beta$, em condições de hipóxia, como durante o sono, onde a córnea é recoberta pela pálpebra, formando assim heterodimeros inativos impedindo então o complexo HIF-1 $\alpha$ :HIF- $\beta$ de transcrever genes como o VEGF, mantendo então o fenótipo avascular da córnea $(101,110)$. Já em câncer renal (RCC células), a ligação de HIF-3aa4 interage com HIF-2 $\alpha$ levando também a formação de complexos inativos, reduzindo a expressão de genes envolvidos em hipóxia e progressão do câncer, sendo sugerido assim como uma opção terapêutica para diversos tipos de câncer onde HIF-1 $\alpha$ e $-2 \alpha$ são expressas (111). Estruturalmente a isoforma $3 \alpha 4$ contêm o domínio de ligação ao DNA (bHLH), dois domínios tipo PAS (PASa e PASb), faltando o domínio ODD e N-TAD e, portanto, é insensível a redução dos níveis intracelulares de oxigênio, ao contrário da isoforma -3 $\alpha 9$ que contêm todos domínios funcionais, bHLH, PASa e PASb, ODD e NTAD. De todas as isoformas HIF$3 \alpha$, a IPAS é a mais estudada do ponto de vista celular, e em relação às outras isoformas, em muitos trabalhos é reportada apenas como HIF-3 $\alpha$ sem fazer especificidade sobre qual das isoformas se trata, dificultando assim a comparação de atividade para cada um dos splicing gerados.

Desde sua descoberta, HIF-3 $\alpha$ sempre tem sido reportada como sendo regulador negativo para as demais isoformas e sua atividade transcricional permaneceu desconhecida. Esse fato é em parte devido à ausência do domínio de transativação CTAD o que reduziria sua atividade transcricional e impediria a ligação a proteínas transativadoras. No entanto, esse estereotipo foi recentemente quebrado e a atividade transcricional da isoforma HIF-3 $\alpha 9$ foi confirmada em zebrafish, no qual regulou a expressão de 58 genes exclusivos como o sqrdl, $\mathrm{mclb}, \mathrm{zp} 3 \mathrm{v} 2$, igfbp-1b, redd1, mlp3c, genes envolvidos na via de sinalização Jak-Stat e nas vias de sinalização do receptor NOD-like. Além disso, houve a expressão de outros 97 genes também regulados pela HIF-1 $\alpha(103,108,112,113)$. Além deste genes, foi demonstrada a atividade de transcrição a genes não relacionados diretamente a hipóxia o que levou ao remodelamento do epitélio pulmonar através da ligação ao elemento responsivo bem como a indução da expressão no gene SOX-2, que desempenha um papel importante na manutenção das propriedades de células de câncer pluripotentes $(114,115)$.

Recentemente foi reportada a atividade não-transcricional de HIF-3a1 em células de tumor colorretal onde está superexpressa tanto em camundongo quanto em tecidos de pacientes, e sua localização celular é reportada somente no citosol. Em decorrência disso, autores observaram que houve o crescimento celular em tamanho e aumento na quantidade de colônias formadas através da ativação da via de sinalização JAK-STAT3, que é conhecida por promover proliferação e sobrevivência celular. No entanto o mecanismo pela qual HIF-3 $\alpha 1$ ativa essa via ainda não foi elucidada (116).

A existência de tantas isoformas tornou o estudo da HIF-3 $\alpha$ ainda mais desafiador no sentido caracterizar as suas respectivas expressões e funções celulares, qual forma delas é a mais ativa ou se as condições de hipóxia levam a diferentes papéis cada uma. De acordo com as 
características estruturais das isoformas confirmadas em nível proteico, o domínio PAS é um fator comum entre elas, exceto para a isoforma - $3 \alpha 4$ que possui uma sequência diferente neste domínio. De modo a obter informações estruturais da HIF-3 $\alpha$ que possam auxiliar na compreensão de sua atividade relacionada a transcrição de genes e também nas novas funções que têm sido associadas a ela, nosso interesse maior foi o de desenvolver um estudo estrutural que envolvesse o domínio PASb da HIF-3 $\alpha$ que gerassem resultados que pudessem ser entendidos e aplicados a todas as isoformas.

A atividade biológica e a regulação dos processos celulares ocorrem através da interação entre proteínas ou mesmo de proteínas com íons, pequenas moléculas orgânicas ou inorgânicas e com macromoléculas, como o DNA e o RNA. Um dos mediadores destas interações são os domínios do tipo PAS (Per-ARNT-Sim). Essa nomenclatura foi estabelecida após a verificação de uma região conservada entre a proteína do ciclo circadiano $(\underline{P E R I O D)}$ de drosófila, a proteína de vertebrados Aryl Hydrocarbon Nuclear Translocator (ARNT) e a proteína reguladora do desenvolvimento single-minded de drosófilas $(\underline{S} I M)$ originando a nomenclatura PAS (Henry \& Crosson, 2011; Möglich, Ayers, \& Moffat, 2009).

Estes domínios são encontrados frequentemente nos três reinos da vida (bactérias, archea e eucariotos) com uma cópia no genoma ou em cópias múltiplas (em tandem) dentro de uma única proteína (117). Ao longo da evolução, os domínios PAS foram selecionados pela grande habilidade de se ligar a diferentes cofatores e ligantes, tornando-se sensores capazes de perceber parâmetros ambientais, como a incidência de luz, pressão parcial de um gás e potencial redox. Além disto, existem muitos domínios PAS que não necessitam de íons ou cofatores para exercer sua função celular $(117,118)$.

A identidade sequencial nestas proteínas é muito baixa (em torno de $20 \%$ ) quando comparadas às estruturas primárias, entre as sequencias de humano, bactéria (E. coli), alga do tipo clamidomonas e plantas (Arabidopsis), que apresentam 12, 22 e 18\% de identidade, respectivamente. No entanto as características estruturais são bastante conservadas e, sua estrutura terciária é caracterizada pelo arranjo antiparalelo de cinco folhas $\beta$ enoveladas partindo no $\mathrm{N}$-terminal para o C-Terminal, composta aproximadamente por 100 a 150 aminoácidos (118). Um exemplo típico de sua topologia pode ser visualizado na figura 8 onde observamos o arranjo de topologia e suas estruturas terciárias.

$4 \mathrm{H} 6 \mathrm{~J}$
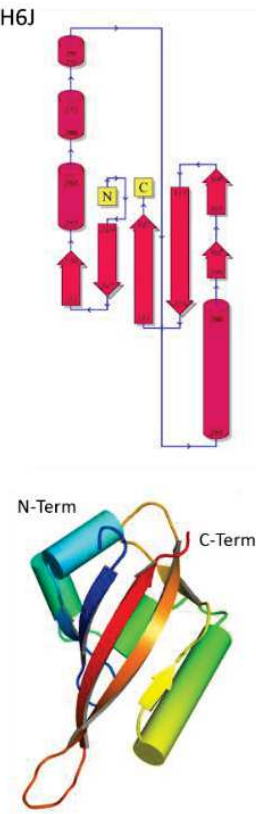

$1 \mathrm{~V} 9 \mathrm{z}$
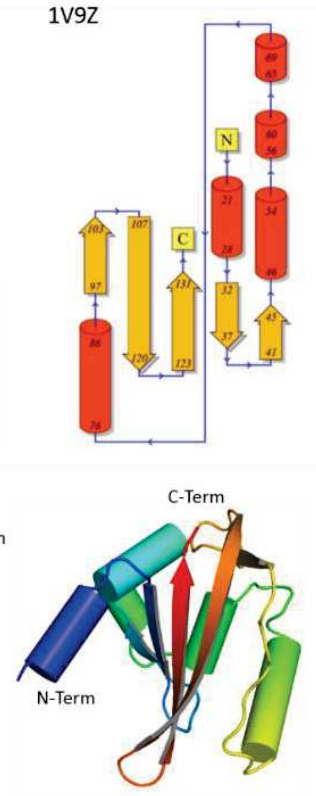

$1 \mathrm{~N} 9 \mathrm{~L}$
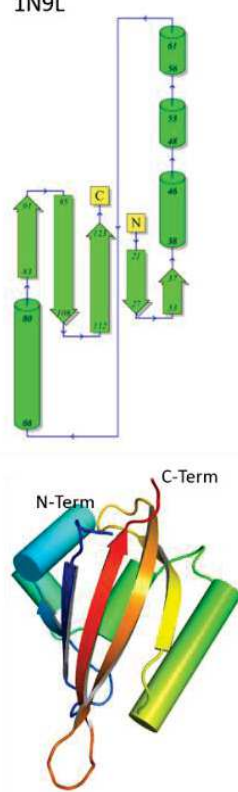

$2 z 6 C$
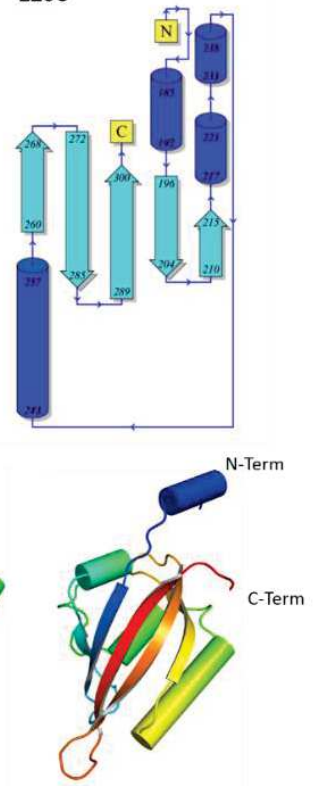

Figura 8. Estrutura de topologia e cristalográfica dos domínios tipo PAS, ilustrando a comparação entre os organismos Humano, E.coli, Chlamydomonas reinhardtii Arabidopsis thaliana. 
As interações proteína:proteína nos domínio tipo PAS ocorrem normalmente através da superfície formada pelas folhas $\beta$, enquanto que os diferentes tipos de ligantes (pequenas moléculas) que interagem com estes domínios ficam abrigados em bolsões hidrofóbicos formados entre as $\alpha$-hélices e as folhas beta $(117,120)$. No caso das HIF's, são encontrados dois domínios PAS em tandem, denominados PASa e PASb, e até o presente momento, não foi identificada a necessidade de cofatores ou ligação com íons para sua atividade funcional, ocorrendo simplesmente a heterodimerização através dos domínios PAS com a HIF-1ß ou ARNT (aryl hydrocarbon receptor nuclear translocator).

\subsubsection{Contribuições do candidato na área.}

Em meados de 2010, com o bom andamento das pesquisas em glutaminases, senti a necessidade de começar a expandir os assuntos do laboratório, com foco em estudos estruturais. Como mencionei em meu memorial, parte do meu projeto de doutorado previa a cristalização do receptor nuclear PPARy humano (um fator de transcrição) em complexo com fragmentos de seu elemento responsivo. Apesar de, durante o doutoramento, não ter conseguido alcançar tal objetivo, ainda estava motivado a tentar cristalizar um complexo proteína:DNA.

Ao estudar as revisões que eram frequentemente publicadas, ficou claro para mim que HIF seria um alvo interessantíssimo, com bastante potencial de descobertas inéditas e coerente com o tema do laboratório. Naquela ocasião, existiam somente estruturas cristalográficas do domínio PASb das subunidades $1 \alpha$ ou $2 \alpha$ em complexo com o domínio equivalente em $1 \beta$. Durante 2011 e 2012, como tema de uma dissertação de mestrado de uma aluna, inúmeros esforços foram dedicados para o objetivo de cristalizar o heterodímero de HIF com seu elemento responsivo. Conseguimos purificar diversas construções das duas proteínas, combinando diferentes domínios. Adquirimos também vários oligonucleotídeos da sequência alvo de HIF. Todavia, o sucesso na cristalização não foi possível.

Com a aproximação do final do projeto de mestrado, no início de 2013, decidimos que uma alternativa mais segura para a conclusão da dissertação seria a cristalização do domínio PASb de HIF-3 $\alpha$ humana, que ainda continuava desconhecida. A construção da proteína, para expressão em sistema bacteriano, e suas respectivas purificação e cristalização foram rapidamente alcançadas com sucesso. Dados de difração a altíssima resolução para esses cristais foram coletados em setembro de 2013, no síncrotron PETRA III, na Alemanha. Para nossa completa surpresa, após a conclusão da construção do modelo atômica, observamos uma cavidade bastante volumosa $\left(\sim 500 \AA^{3}\right)$, dentro da qual se encontrava uma molécula de lipídeo bacteriano.

Os próximo meses, já durante o doutoramento da aluna, foram dedicados para a caracterização do(s) lipídeo(s) que estavam interagindo com a proteína recombinante. Ensaios in vitro mostraram que a proteína é capaz de se ligar a diferentes tipos de lipídeos, os quais foram submetidos à análise por espectrometria de massas através da extração da fase orgânica da amostra; foram identificados dois liso-fosfolípideos. De modo a explorar a cavidade hidrofóbica presente na estrutura e identificar outros lipídeos que possam também se ligar a proteína, realizamos ensaio de delipidação e titulação de ácidos graxos livres com diferentes comprimentos da cadeia carbônica e níveis de insaturação, que pudessem estar presentes no organismo humano. Como resultado observamos uma alta afinidade com ácidos graxos oleico e linoleico, ambos com alta afinidade, na faixa de nanomolar.

O trabalho foi publicado em agosto de 2015 (121). Esta é a primeira, e até hoje, a única, descrição de um ligante intracelular não-covalente de HIF. Pode, possivelmente, ditar a expressão do gene dependente em resposta à metabolismo biossintético e/ou energético, tal como a acumulação ou depleção de lipídeos, em exposição à hipóxia. Mais ainda, estes 
resultados evidenciam, de maneira inédita, que um domínio PAS eucariótico pode servir como um sensor para os níveis intracelulares de lipídeos.

De minha parte, essas pesquisas foram financiadas por dois Auxílios Regulares FAPESP, sob minha responsabilidade: 2010/05003-0 e 2012/14298-9. Uma dissertação de mestrado e uma tese de doutorado, sob minha orientação, foram concluídas. Atualmente está em andamento uma outra dissertação de mestrado, cuja proposta de pesquisa é dedicada ao estabelecimento dos modelos celulares para o estudo de quais lipídeos interagem com a proteína e descoberta dos potenciais efeitos dessa interação na regulação da expressão genica mediada por HIF, como colocado acima. Já estamos começando a realizar experimentos de espectrometria de massas para detectar/identificar potenciais lipídeos na proteína imunoprecipitada. Sandra é coorientadora neste projeto. A publicação que resultou desta linha de pesquisa, até o momento, encontra-se listada a seguir. A versão completa do manuscrito está disponível no Anexos II.1.

- Anexo II.1: Fala, A. M., Oliveira, J. F., Adamoski, D., Aricetti, J. A., Dias, M. M., Dias, M. V. B., Sforça, M. L., Lopes-de-Oliveira, P. S., Rocco, S. A., Caldana, C., Dias, S. M. G., and Ambrosio, A. L. B. (2015) Unsaturated fatty acids as high-affinity ligands of the C-terminal Per-ARNT-Sim domain from the Hypoxia-inducible factor 3 $\alpha$. Scientific Reports 5, 12698.

\section{Co-autor de correspondência.}




\subsection{Carreador mitocondrial de piruvato, MPC (2013 - presente)}

The processing of pyruvate is a critical branch of carbon metabolism within the cells, both from the standpoint of energy and biosynthesis. Therefore, pyruvate gaining access to the mitochondria is an essential step that provides the cell with its energy currency, ATP, besides providing for the carbon skeleton for the synthesis of diverse molecules. Although the existence of a carrier for pyruvate has been anticipated for more than 40 years (122), its molecular identity remained unknown until recently.

For the cytosolic pyruvate to have access to the mitochondrial matrix, three layers must be crossed: the outer mitochondrial membrane (OMM), the intermembrane space and the inner mitochondrial membrane (IMM). The transport through the outer mitochondrial membrane is easily accomplished by major non-selective channels, since this membrane is completely permeable to small molecules and ions. The movement across the inner mitochondrial membrane is, on the other hand, much more restrictive and typically involves the presence of specific transporters, which lead to the question of how pyruvate can go through the inner mitochondrial membrane (figure 9).

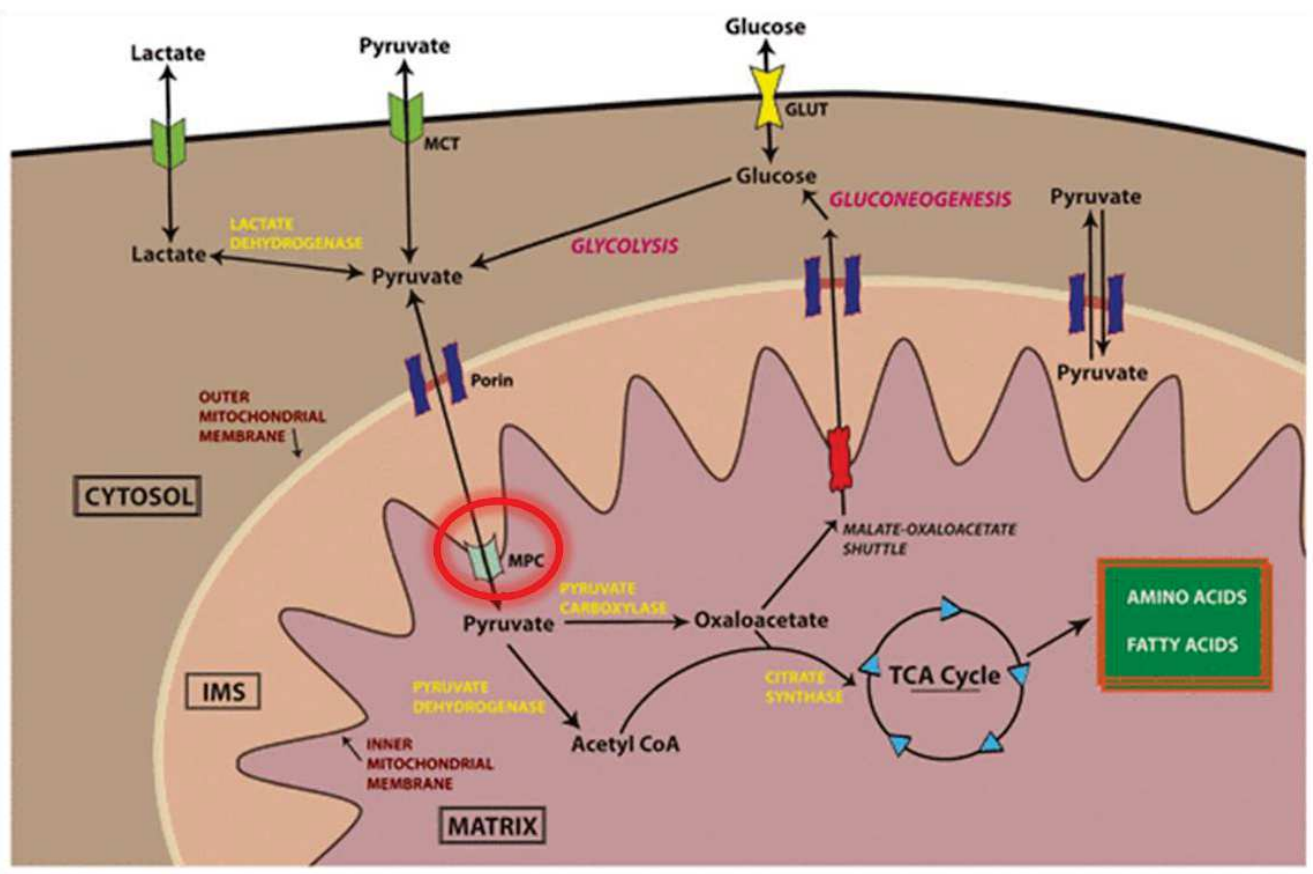

Figure 9: Cellular metabolism of pyruvate. Carrier of the mitochondrial pyruvate (MPC), highlighted in red circle, is located at the IMM and responsible for the import of pyruvate from the intermembrane space to the mitochondrial matrix. Adapted from (123).

In June 2012, two papers published simultaneously in Science by independent research groups, identified two internal mitochondrial membrane (IMM) proteins, MPC1 and MPC2, as essential for the transport of pyruvate in yeast (S. cerevisiae), Drosophila and humans $(124,125)$. In yeast, a third member, MPC3, has also been identified. MPC2 and MPC3 share $79 \%$ sequence identity to each other and there is evidence that they are products of a recent gene duplication event. These proteins have three predicted transmembrane helices (124) (figure 10). Although each of the subunits have about $15 \mathrm{kDa}$ of molecular weight (or about 130 amino acids), the complex is suggested to possess $150 \mathrm{kDa}$, indicating a decamer, but its exact stoichiometry is 
not yet known. MPC1 cannot be a part of this complex without MPC2, whereas MPC2 can form the complex without MPC1 (125). This indicates that MPC2 is the major structural unit of the multimeric complex.

Mutant yeast strains, $m p c 1 \Delta$ and $m p c 2 \Delta$, deleted individually for each subunit, showed growth defects in medium lacking leucine, in glucose medium and in glycerol medium [Bricker DK, et al. 2012]. Also, $m p c 1 \Delta$ and $m p c 2 \Delta m p c 3 \Delta$ cells grew more slowly in amino acid-free medium (124), the growth defect being rescued by leucine or valine or both. $m p c 2 \Delta$ had somewhat reduced growth, while $m p c 3 \Delta$ showed no phenotype in amino acid free medium. $m p c 1 \Delta$ phenotype was rescued by yeast, Drosophila and human MPC1 $(124,125)$. mpc2 $\Delta m p c 3 \Delta$ phenotype was rescued in yeast by either MPC2 or MPC3 (124). Mutant Drosophila strains lacking MPC1 were defective in carbohydrate metabolism, and were rescued with wild-type MPC1 (125). These mutant strains showed elevated levels of pyruvate and amino acids that can interconvert with glycolytic intermediates, and depleted levels of acetyl CoA and amino acids that can interconvert with TCA cycle intermediates. Similarly, $m p c 1 \Delta$ and $m p c 2 \Delta$ yeast strains had elevated levels of pyruvate and CoA and depleted levels of malate and acetyl CoA. This indicates that the mutants are unable to convert cytosolic pyruvate to mitochondrial acetyl CoA to drive the TCA cycle.
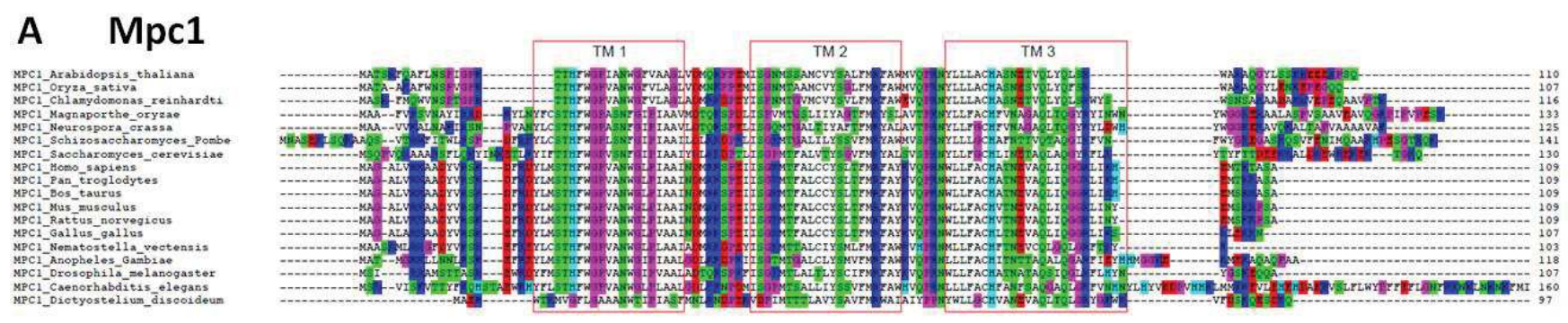

\section{Mpc2}
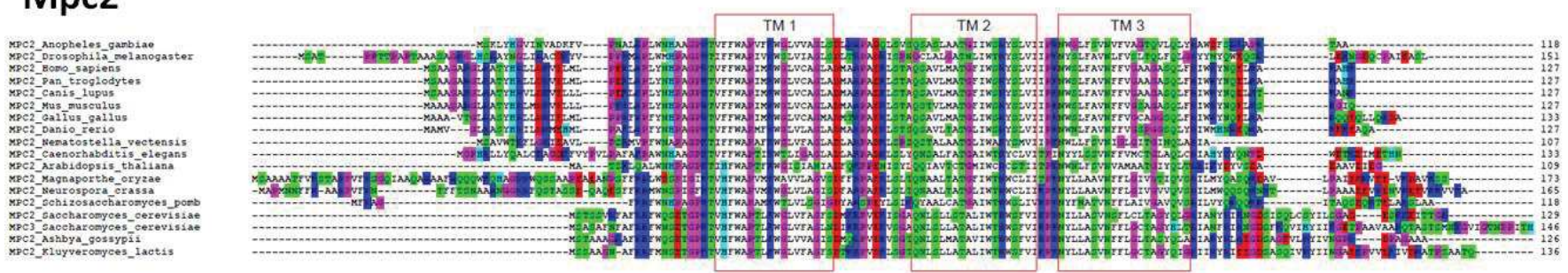

B
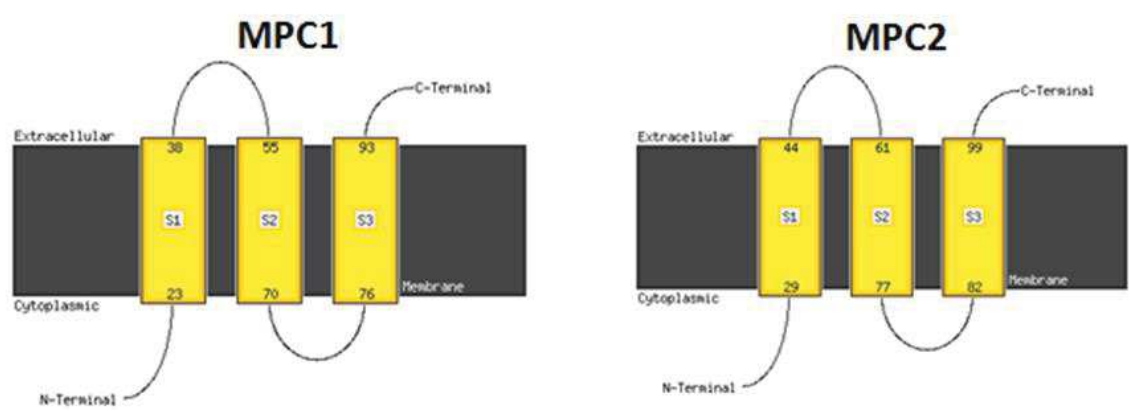

Figure 10: (A) Sequence alignment of MPC1 and MPC2 between several organisms, highlighting conserved transmembrane regions, delimited by the red boxes. (B) Representation of the transmembrane regions (TM1, TM2 and TM3) and predicted orientation in the membrane for MPC1 and MPC2, as predicted by MEMSAT3 [5]. Figures adapted from [Bricker DK, et al. 2012]. 
Herzig et al. have found that less than $2 \%$ of the amount of valine and leucine metabolized by the WT is metabolized in the mutant yeast strains (125). They found this to be the result of impairment on the activity of the lipoyl-dependent complexes such as pyruvate dehydrogenase and $\alpha$-ketoglutarate dehydrogenase in $m p c 1 \Delta, m p c 2 \Delta$ and $m p c 2 \Delta 3 \Delta$ cells grown in amino acid free medium. They determined the defective step in the lipoic acid synthesis pathway in $m p c 1 \Delta$ cells to be upstream to acetyl CoA metabolism. The phenotype was similar to pyruvate dehydrogenase deficient cells. Since pyruvate dehydrogenase activity was normal in $m p c 1 \Delta$ cells in rich medium $(124,125)$, MPC proteins seemed to act upstream of pyruvate dehydrogenase, proving its involvement with the transport of pyruvate from the cytosol to the mitochondria.

Isolated mitochondria from $m p c 1 \Delta, m p c 3 \Delta$ and $m p c 2 \Delta m p c 3 \Delta$ cells grown in lactate medium showed decreased pyruvate uptake compared to WT despite a normal mitochondrial membrane potential (124). Isolated mitochondria from $m p c 1 \Delta$ cells were also shown to be defective in pyruvate uptake by Bricker et al. (125). Pyruvate transport, however, was normal in mpc2 $\Delta$ mitochondria (124). The difference in sensitivity of $m p c 2 \Delta$ and $m p c 3 \Delta$ strains in amino acid-free medium and lactate medium was explained by the discovery that in amino acid free medium yeast expressed mainly MPC2 whereas in lactate medium they mainly expressed MPC3. Thus, it seems likely that MPC2 and MPC3 have different non-redundant functions under different growth conditions.

Hetereologous MPC1 and MPC2 from mouse functionally complement each other in $m p c$ deleted yeast strains. Depletion of either MPC1 or MPC2 in mouse fibroblasts resulted in slight decrease in pyruvate-driven oxygen consumption and a stronger decrease in the presence of carbonyl cyanide- $p$-trifluoromethoxyphenylhydrazone (FCCP), which stimulates maximal respiration (125). This suggests that murine MPC1 and MPC2 function in pyruvate transport similar to yeast and Drosophila. When MPC1 and MPC2 from mouse were coexpressed in the bacterium Lactococcus lactis, four-fold pyruvate uptake was detected compared to the empty vector control or expression with either MPC alone (124). This pyruvate uptake depended on a proton electrochemical gradient, and was sensitive to the mitochondrial pyruvate carrier inhibitor UK5099.

Families with defective mitochondrial pyruvate transport have mutations in their DNA sequences, which result in the Leu79His and Arg97Trp substitutions (125). Leu 79 is conserved amongst the MPC1 orthologs, while Arg 97 is conserved amongst the orthologs of both MPC1 and MPC2. Cells from the affected individuals had impaired pyruvate-driven oxygen consumption. Expression of WT MPC1 in these cells completely or partially rescued the pyruvate oxidation defect. Leu79His and Arg97Trp alleles of MPC1 were much less effective in rescuing yeast $m p c 1 \triangle$ growth defect compared to human WT MPC1, suggesting that MPC1 function is evolutionarily conserved from yeast to man.

Concerning to the molecular aspects of the MPC, as previously mentioned, it has been proposed that the complex has a molecular weight of $150 \mathrm{KDa}$, much bigger than the molecular weight of the MPC1 and MPC2 monomers, based on its migration pattern on non-denaturing electrophoresis (125). However, this conclusion is still controversial, since such a technique is influenced mainly by the shape and net charge of the molecule rather than its molecular size. A proper experimental approach would be required for a reliable determination of the molecular size of the complex, such as analytical ultra-centrifugation and/or size-exclusion couple to multiangle static light scattering, which could only be achieved if either endogenous or recombinant MPC were purified from membrane fractions. Another open question is the relative stoichiometry of the two subunits. 
In this context, we proposed this research in our lab which aims to contribute towards the understanding of the underlying mechanisms of pyruvate shuttling across the mitochondrial membrane; this is a basic and crucial mechanism for cell energy and biosynthetic pathways. The first question we would like to approach is related to the molecule assembly of the MPC, in regards to its size and subunit composition. Our hope is that once we can reconstitute the functional MPC complex in vitro, structural studies can also be performed, such as cryo-electron microscopy and $x$-ray crystallography, with the intent of providing the structural basis for pyruvate shuttling across the complex. Divakaruni and coworkers (126) reported that clinically relevant concentrations of thiazolidinediones (TZDs) are capable of strongly and specifically inhibit the activity of mitochondrial pyruvate carrier in a variety of cell types. The TZDs, also known as glitazones, were introduced in the late 1990s and are a class of medications used in the treatment of diabetes mellitus type 2 , and have long been believed to act specifically on the peroxisome proliferator-activated receptors (PPAR). We also set as a goal for this project to contribute to the understanding of the TZD-dependent inhibition mechanism of the MPC complex. The complex formation between MPC and TZDs may also help stabilize the overall complex and perhaps will facilitate complex purification and extraction. Usually, ligands can increase the overall hydrophilicity of complexes, helping improving its stability. This especially holds good for membrane proteins as they have short loops connecting the transmembrane helices. Second, binding of a ligand may stabilize one specific conformation of membrane protein thereby increasing the structural homogeneity of the protein sample (127-129), thus facilitating crystallization.

\subsubsection{Contribuições do candidato na área.}

Apesar dos temas acima tratarem de enzimas (glutaminases) e fatores de transcrição (HIF), esse, na verdade, é o segundo trabalho de nosso grupo visando estudos estruturais proteínas de membrana; porém, é de fato o primeiro no tema de metabolismo tumoral. Este projeto foi derivado de uma experiencia nossa anterior, bem-sucedida, com uma proteína associada à membrana mitocondrial do fungo causador da doença Vassoura-de-Bruxa, em cacaueiros; mais precisamente, durante o desenvolvimento de nosso projeto colaborativo com o Dr. Gonçalo Amarante Pereira, da Unicamp, dentro da chamada SMOLBnet 2.0, da FAPESP (janeiro de 2011 a dezembro de 2012). Na ocasião, tentamos produzir a Oxidase Alternativa (AOX), uma proteína também associada à membrana mitocondrial, de $M$. perniciosa, e de grande interesse para o desenvolvimento de pequenos inibidores químicos. Obtivemos sucesso no aprendizado e implementação de protocolos de preparação e extração das proteínas de extratos de membranas, seleção por detergentes e purificação.

Mais de quatro décadas atrás, no início de 1970, Andrew Halestrap (Universidade de Bristol) demonstrou pela primeira vez a natureza ativa, isto é, dependente de proteína, do transporte de piruvato do citosol para a mitocôndria. Em fevereiro de 2012, participei de um simpósio da série Keystone, em Banff, no Canadá, cujo tema era Câncer e Metabolismo. Na ocasião, Dr. Jared Rutter (University of Utah), palestrante, apresentou a identidade das proteínas MPC, encarregadas desse processo previsto por Halestrap. Alguns meses mais tarde, seu trabalho seria publicado na Science, em paralelo com o trabalho do laboratório do Dr. Jean-Claude Martinou (Université de Genève).

Os laboratórios dos doutores Rutter e Martinou isolaram e identificaram, de forma independente, MPC1 e MPC2, e propuseram sua associação funcional em uma estrutura oligomérica de $150 \mathrm{kDa}$; este oligômero seria formado pela associação entre as duas subunidades. Essas importantes publicações abriram as portas para estudos subsequentes que caracterizaram ainda mais o papel e a regulação do transporte de piruvato dependente de MPC, 
no entanto, exclusivamente no contexto mitocondrial. Independentemente, criticismos à essas publicações, partindo principalmente do próprio Andrew Halestrap, foram constantemente levantadas; e persistem até a data, sobre a natureza funcionalmente independente do MPC1: MPC2. Rapidamente, se tornou consenso que o isolamento e a purificação até a homogeneidade de MPC1 e MPC2, e subsequente reconstituição em vesículas artificiais seria o experimento obrigatório para medir o transporte de piruvato dependente de MPC.

Quando assisti a palestra do Dr. Rutter, em 2012, estávamos trabalhando com AOX. Tínhamos adquiridos reagentes e equipamentos para o projeto; uma pós-doutoranda de meu grupo, que conduzia as pesquisas com AOX, tinha também participado de um curso sobre purificação de proteínas de membrana. Devido ao fato de MPC ser totalmente inédito, e termos uma certa capacidade técnica, decidi que seria interessante nos aventurarmos no tema de MPC.

Ainda em 2012, tive a oportunidade de conversas com dois dos maiores especialistas mundiais em estudos estruturais de proteínas de membrana sobre nossos planos para MPC. Um desses especialistas é a Dra. Isabel de Moraes, diretora do Membrane Protein Laboratory (MPL), localizado no síncrotron Diamond Light Source, em Didcot, no Reino Unido. Com o plano de pesquisa traçado, durante o ano de 2013, tive uma aluna de graduação estagiando em meu laboratório, que realizou a montagem do sistema de expressão a ser usado, que seria leveduras, e também a adaptação de um vetor e subclonagem de dez pares homólogos de MPC, desde humanos, passando por plantas, mosca, mosquito, até nematódeos.

A pesquisa em nosso laboratório foi então projetada com o objetivo de ajudar a responder à questão relevante, e de longa data, que diz respeito à verdadeira natureza dos transportadores de piruvato glicolítico através da membrana mitocondrial interna. Então, em meados de 2014, recrutei um pós-doutorando, que assumiu o projeto. Logo em seguida, um aluno de doutorado se juntou. Desde então, considero que temos tido enorme sucesso nessa empreitada. Nosso primeiro manuscrito, descrevendo justamente a purificação e reconstituição funcional em vesículas artificiais está em fase de revisão. Na verdade, aliado a nossos esforços, o sucesso desse trabalho se deve enormemente à colaboração continua da Dra. Isabel de Moraes, que, na verdade, nos ajuda até hoje, inclusive hospedando membros de meu grupo no MPL. Também, tivemos a enorme felicidade de conhecer o laboratório do Dr. Pietro Ciancaglini, da USP de Ribeirão Preto, que foi fundamental para o estabelecimento dos ensaios de transporte in vitro. Foi por meio da Dra. Eneida de Paula, da Unicamp, que chegamos até o Dr. Ciancaglini.

Neste manuscrito, que ajuda a resolver a questão da real funcionalidade de MPC, como proposto em 2012, relatamos a primeira produção heteróloga MPC na literatura, já com o homólogo humano. Foram planejadas estratégias de coexpressão e purificação para isolar o complexo funcional esperado de $150 \mathrm{kDa}$, que, no entanto, permitiu apenas a purificação dos componentes individuais e em pesos moleculares aparentes mais baixos. Mais especificamente, MPC1 foi purificado com sucesso, mas co-eluído com uma chaperona do hospedeiro, e apenas com muitos traços de MPC2; não foi observada atividade de transporte in vitro para esta proteína.

Por outro lado, mostramos que MPC2 humano purifica até a homogeneidade na ausência total de MPC1, novamente, apesar de uma co-expressão recombinante e induzível. Fornecemos então a primeira demonstração de que o MPC2 pode funcionar como um transportador autônomo, de forma oligômeros. Mais importante ainda, a coleção de parâmetros funcionais descritos no nosso artigo está de acordo com as publicações anteriores e recentes, incluindo dos doutores Halestrap, Rutter e Martinou, que sugerem que o transporte de piruvato mitocondrial pela MPC é um processo rápido e específico, depende da co-importação de prótons e do equilíbrio redox. Nosso artigo culmina com a confirmação de que MPC2 humano pode funcionar como um transportador autônomo em um modelo celular levedura. 
Além dos pontos acima mencionados, também propomos um simples ensaio de atividade de transporte in vitro que não requer o uso de substratos radioativos, o que muitas vezes é uma limitação séria para muitos laboratórios, incluindo o nosso.

Essas pesquisas foram, e ainda são, financiadas por Auxílios Regulares FAPESP, sob minha responsabilidade: 2012/14298-9, 2014/20673-2 e 2017/117665. Uma tese de doutorado está em andamento, assim como um projeto de pós-doutoramento. Uma cópia do manuscrito em revisão (título e lista de autores abaixo) encontra-se no anexo III.1.

- Anexo III.1: Nagampalli, R. S. K., Quesñay, J. E. N., Adamoski, D. Islam, Z., Birch, J., Sebinelli, H. G., Ascenção, C. F. R., Fala, A. M., Pauletti., B. A., Consonni, S. R., Oliveira, J. F., Silva, A. C. T., Franchini, K. G. Paes Leme, A. F., Ciancaglini, P., Moraes, I., Dias, S. M. G., and Ambrosio, A. L. B. (2017) Human mitochondrial pyruvate carrier 2 as an autonomous and selective transporter. Under review. 


\subsection{Prolil-hidroxilases, PHD (2012 - presente)}

As PHDs pertencem à família das enzimas dioxigenase, que fazem a hidroxilação de resíduos de prolina, requerendo oxigênio, ferro e 2-oxoglutarato (2-OG) para a sua atividade catalítica. A sua baixa afinidade com o oxigênio - de cerca de 2 a 10 vezes superiores às concentrações fisiológicas de oxigênio - permite com que as enzimas atuem como sensores de oxigênio, sendo classificadas como tal (130). Três isoformas das PHDs (PHD1, PHD2 e PHD3) foram identificadas e os seus substratos são conhecidos como sendo bastante diversos e específicos de cada isoforma. Umaa quarta isoformas também é descrita, porém, bem menos estudada.

PHD1 controla o nível de expressão do fator-kappa das células B ativadas (NF-kB) por inativação mediada por hidroxilação do inibidor de NF-kB quinase (131). Além disso, PHD1 está envolvida na proliferação celular através da degradação de um regulador do ciclo celular da ciclina D1 em uma maneira dependente da atividade de hidroxilase (132). A subunidade maior da RNA polimerase II Rbp1 tem sido mostrado como o outro substrato para PHD1, e a prolil hidroxilação é necessária para a sua degradação dependente de VHL.

PHD2 é considerada crítica na regulação da via de HIF, embora a atividade de hidroxilase seja necessária para a regulação de outras vias de sinalização incluindo fosforilação cofilina e a degradação da proteína NDRG3 $(133,134)$. Especificamente, a angiogênese aumentada e o aumento dos níveis do fator de crescimento endotelial vascular (VEGFA) e eritropoietina (EPO) foram observados em nocaute condicional de $\operatorname{PHD} 2(135,136)$. Tais observações, juntamente com que já havia sido descrito para HIF, reforçam a presença EPO circulante e concomitante aumento da eritropoiese (87), o que implica que a ativação de HIF por moduladores das PHDs poderia ser benéfico para pacientes com doenças relacionadas a anemia e com a isquemia. Assim, abordagens farmacológicas como inibidores da atividade hidroxilase das PHDs afim de manipular a via de HIF têm sido estudadas para o tratamento de doenças sistêmicas e locais relacionadas com a hipóxia.

Por outro lado, PHD3 desempenha papéis importantes no desenvolvimento neural, na função do sistema imunológico, na migração celular e na apoptose (137). O fator de ativação de transcrição 4 e o homólogo humano da proteína de C. elegans clock protein CLK-2 foram identificadas como substratos não-HIF para $\operatorname{PHD} 3(138,139)$. Actina não-muscular também é hidroxilada em resíduos de prolina por PHD3 e a inibição da atividade PHD3 leva ao aumento de filamentos de F-actina (140). Distintamente da sua atividade de hidroxilase, PHD3 pode atuar como uma proteína que está presente na regulação de diversas vias de sinalização $(141,142)$.

Uma quarta prolil hidroxilase foi descoberta, esse gene está presente em mamíferos e também foi identificado em zebrafish. Ela difere das demais PHDs devido a sua localização celular, pois sua sequência contêm um domínio transmembrana e ela está associada ao retículo endoplasmático com seu domínio catalítico voltado para o lúmen do reticulo. PHD4 em ensaios in vitro foi capaz de hidroxilar o peptídeo referente as prolinas de HIF no domínio de degradação dependente de oxigênio, no entanto especula-se que essa proteína tenha outros substratos devido ao alto grau de redundância por outros substratos (143).

Em termos de sequência primária, os genes humanos das PHDs são bem conservados, especialmente no domínio do sítio ativo. PHD1 e PHD2 contém um sinal de localização nuclear no N-terminal e PHD2 contém ainda uma sequência de exportação nuclear e motivo ZF-Mynd, o que pode permitir a interação com outras proteínas. Ambas as enzimas são relatadas como citoplasmáticas, no entanto, ambas foram recentemente encontradas no núcleo, consistente com os peptídeos de sinalização acima, sugerindo que a sua atividade sobre HIF também ocorre no núcleo. A Figura 11 mostra a arquitetura dos domínios das PHDs. 


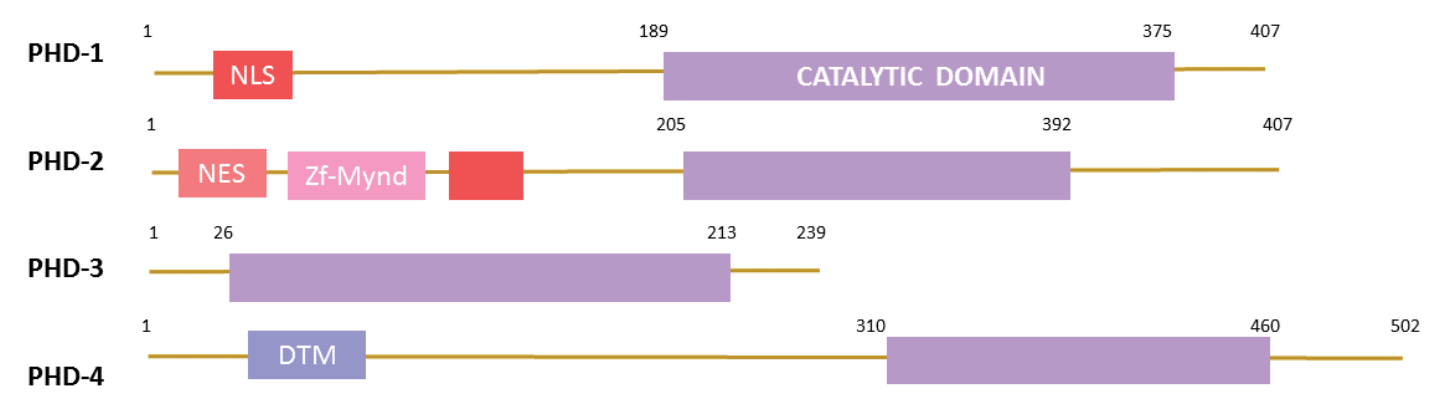

Figura 11. Representação esquemática da arquitetura das PHDs 1-4. As quatro isoformas possuem domínio catalítico, requerido para função enzimática. Adicionalmente PHD1 possui um motivo de localização nuclear (NLS), PHD2 apresenta os motivos de exportação para o núcleo (NES), de interação com outras moléculas (zf-Mynd) e o sinal de localização nuclear (NLS), PHD4 possui um domínio transmembrana (DTM) além do domínio catalítico.

PHDs catalisam a hidroxilação dependente de Fe (II) e oxigênio de dois resíduos específicos de prolina. Sob condições de normóxia a hidroxilação de ODD (Pro-402 e Pro-564) nas HIF-1 $\alpha$ e $-2 \alpha$, favorece a ligação do supressor de tumor VHL levando-as a poli-ubiquitinação e sinalizando para degradação proteossômica (144). Em condições de hipóxia, a prolil-4-hidroxilação é reduzida, e HIF-1 $\alpha$ e HIF-2 $\alpha$ tornam-se estabilizadas e translocam-se para o núcleo onde heterodimerizam-se com a subunidade constitutivamente expressa HIF-1 $\beta$ e regulam a expressão dos diversos genes-alvo.

Apesar das PHDs possuírem domínios catalíticos parecidos, elas exibem tendência quanto a isoforma a ser hidroxilada, HIF-1 $\alpha$ ou $2 \alpha$, e quanto ao sítio de hidroxilação (CODD ou NODD), por exemplo, PHD3 preferencialmente hidroxila a HIF-2 $\alpha$ em diversas linhagens celulares e PHD1 e 2 preferencialmente hidroxilam HIF-1 $\alpha$ (145). Além destas atividade específica das PHDs, a PHD3 é a única isoforma que está sob controle transcricional de HIF-1 $\alpha$, e sua expressão é elevada em tecidos de câncer de pescoço e cabeça e, apesar desta enzima não possuir sinal de localização nuclear, ela está presente tanto no citoplasma quanto no núcleo, indicando assim que possa ter sido carreada através da interação com outras proteínas. Recentemente um ensaio utilizando siRNA contra PHD3 levou a regulação do p27, proteína relacionada ao bloqueio do ciclo celular na fase G1 (146), sugerindo desta forma que as prolil hydroxilases estão envolvidas também em outras vias celulares, direta ou indiretamente, sendo este mais um motivo importante no estudo desta família de proteínas. Até o presente momento somente a estrutura do domínio catalítico da isoforma PHD2 foi elucidado por cristalografia de raios $\mathrm{X}$ ( $p d b$ : $3 H Q R)(147)$.

Apesar do rápido acumulo de informações na literatura no que diz respeito as funções in vitro e celular das PHDs, pouca informação foi reportada quanto à sua estrutura molecular. Somente a PHD2, que é a hidroxilase mais estudada desta classe do ponto de vista estrutural, e até o presente momento, apenas a estrutura do seu domínio catalítico, foi elucidada por cristalografia de raios-X. Tal informação experimental foi um ponto importante para a identificação e teste de inibidores desta prolil hidroxilase (148). Muitos esforços para a determinação estrutural da PHD1 de humanos e mamíferos e outros organismos foram apresentadas ao longo dos anos, porém com pouco sucesso.

Recentemente, outros organismos foram selecionados e utilizados como modelos alternativos para estudar doenças humanas, como cardiopatologias e câncer. Um dos muitos exemplos é o rato-toupeira-pelado (Naked mole rate-NMR, Spalax sp) e a toupeira (Blind mole 
rate-BMR, Heterocephalus glaber). Estes roedores têm um estilo de vida muito peculiar: sua vida subterrânea é formada por grandes colônias e são constantemente submetidos a intensas fontes de estresse, como a escassez de alimentos, condições de baixo oxigênio, escuridão, inundação, exposição a um grande número de patógenos e predação. Além de todas estas atribuições que os tornam vulneráveis, eles possuem uma vida longa em torno de 30 anos, muito acima do esperado para os roedores (149).

Câncer representa $\sim 23 \%$ de mortalidade humana (150). Em roedores, tais como camundongos e ratos a mortalidade por câncer é muito elevada, alcançando $90 \%$ em algumas estirpes (151). Ao longo de um período de 40 anos, milhares de indivíduos de NMR e de BMR foram alojados e estudados em diferentes regiões do mundo, lugares com características mais quentes como deserto e mais frias como os polos, e apesar destes pequenos roedores ( $\sim 100$ 200 gr.) apresentarem uma vida extremamente longa (> 20 anos), nenhum deles jamais desenvolveu tumores espontâneos e nem demonstram nenhuma alteração fenotípicas relacionadas com o envelhecimento.

Eles têm desenvolvido um complexo adaptativo exclusivo para viver no subsolo, incluindo uma capacidade única para lidar com extrema hipóxia e hipercapnia (152). Além disso podem realizar trabalho aeróbico intensivo sob pressões baixas de $\mathrm{O}_{2}$, devido ao aumento da massa muscular, alta densidade de vasos sanguíneos e mitocôndrias, resultando em redução da distância de difusão de oxigênio e fornecimento de oxigênio eficiente mesmo em baixa capilar $\mathrm{PO}_{2}(152,153)$. A espécie Spalax sp possui adaptações em genes relacionadas com a hipóxia na estrutura e função, como a elevada expressão de VEGF e p53 que abriga duas mutações no sítio de ligação do DNA idênticas às mutações do gene p53 em tumores mais comuns (153-155).

Outro modelo alternativo para o estudo fisiológico, em especial os sistemas digestivo e cardiovascular, são as cobras. Especialmente répteis do gênero Python sp. Pythons não utilizam a tática de caçar suas presas, como as demais cobras. Sua abordagem tática é a de esperar a presa se aproximar e, como resultado disto, eles têm uma resposta fisiológica rápida a alimentação e jejum. Durante o curto período de digestão, menos de 24 horas, seus órgãos praticamente duplicam de tamanho e o seu aumento de atividade é em torno de 10 e 40 vezes, o que leva a um aumento na absorção de nutrientes tais como glicose e transportadores e enzimas desta via. O processo inverso também ocorre rapidamente, o seu coração, fígado, pâncreas e rins reduzem a massa e retornam ao repouso rapidamente e sua atividade volta a ser reduzida.

É bem conhecido que a maioria das respostas fisiológicas acima, em especial para a adaptação às condições de hipóxia, angiogênese, eritropoiese, e a adaptação dos processos metabólicos, são controlados por HIFs. Portanto, o envolvimento direto de PHDs nestes processos é uma hipótese muito plausível. Neste contexto e do ponto de vista molecular, nosso interesse é estudar as PHDs destes organismos incomuns e, sobretudo, aprender como eles se comparam com os homólogos humanos. A compreensão de uma possível regulação e supressão do tumor relacionada com as PHDs nestes organismos podem fornecer pistas sobre os mecanismos e as diferenças em comparação com os seres humanos e, portanto, poderia ajudar a encontrar novos alvos para a terapia anticâncer por ativação das mesmas condições para as células humanas ou revelar mecanismos moleculares importantes que são ignorados até agora.

\subsubsection{Contribuições pretendidas.}

Como descrito acima, PHDs são os principais reguladores da presença de HIF nas células. $O$ projeto relacionado às prolil-hidroxilases foi planejado em colaboração com o Dr. Christopher Schofield, professor no Departamento de Química da Universidade de Oxford. Esta colaboração é fruto do trabalho realizado no projeto BEPE FAPESP desenvolvido pela aluna Angela Maria Fala durante o período de mestrado em que esteve no Structural Genomics Consortium (SGC) na 
Universidade de Oxford. Angela foi a aluna responsável pelas pesquisas em HIF e lipídeos, bem como PHDs, em nosso laboratório. Ambos os trabalhos foram tema de sua tese de doutorado pela Unicamp, a qual defendeu em julho de 2017. Os resultados obtidos pela aluna durante o BEPE foram de suma importância para despertar o interesse do professor Schofield; estendemos a colaboração além do SGC, desde 2013, continuamos com projeto aqui no LNBio. Visamos expressar e cristalizar homólogos não-convencionais de PHD, pois o trabalho de outros laboratórios mais estabelecidos na área, como o do próprio Dr. Schofield, tenta, há anos cristalizar homólogos e de mamíferos, como camundongo. Até o momento, temos identificamos condições de cristalização para PHD1 e PHD3. O laboratório do Dr. Schofield realiza os ensaios de atividade, que não são triviais, para confirmar a funcionalidade das enzimas recombinantes que produzimos. Com a conclusão do doutorado da aluna responsável, o laboratório do Dr. Schofield está levando também adiante a otimização das condições de cristalização. 


\subsection{Canal ânion-seletivo dependente de voltagem 2, VDAC-2 (2016 - presente)}

As primeiras observações por microscopia eletrônica de transmissão da mitocôndria definiram sua morfologia básica: uma matriz envolvida por uma membrana interna, uma membrana externa e um espaço intermembranas (156). Recentemente, as técnicas de criomicroscopia eletrônica de partículas isoladas e crio-tomografia eletrônica têm fornecido dados 2D e 3D descrevendo interações entre complexos do sistema de fosforilação oxidativa da mitocôndria e gerando novas percepções de como estes supercomplexos estão estruturados dentro da mitocôndria (157).

A matriz mitocondrial contém uma mistura concentrada de centenas de enzimas, incluindo o complexo da piruvato desidrogenase e as enzimas do ciclo do ácido cítrico, a via de beta-oxidação de ácidos graxos e as vias de oxidação de aminoácidos. Contém ainda várias cópias do DNA genômico mitocondrial, dos ribossomos especiais, dos tRNAs e de várias enzimas requeridas para a expressão dos genes mitocondriais.

A membrana interna possui numerosas cristas que aumentam bastante sua área de superfície, contendo as proteínas que conduzem as reações de oxidação na cadeia respiratória, a enzima ATP-sintase e transportadores específicos que regulam a entrada e saída de metabólitos da matriz. Um gradiente eletroquímico de $\mathrm{H}^{+}$que direciona a ATP-sintase é estabelecido de forma que ela deve ser impermeável a íons e à maioria de pequenas moléculas.

Já no espaço intermembranas existem várias enzimas que utilizam o ATP proveniente da matriz para fosforilar outros nucleotídeos. Neste espaço também ficam alojadas proteínas como citocromo c e Smac/DIABLO e que, dependendo do estímulo pró-apoptótico e de alterações na membrana externa, podem ser liberadas para o citoplasma, desencadeando a via apoptótica mitocondrial (158).

A membrana externa, por sua vez, possui um tipo de proteína formadora de canais, a VDAC (voltage-dependent anion-selective channel), que também é a mais abundante nessa membrana (159). Devido a essa proteína, a membrana externa é permeável a todas as moléculas de até $5 \mathrm{kDa}$. Há ainda outras proteínas envolvidas na síntese de lipídeos mitocondriais e enzimas que convertem substratos lipídicos que serão metabolizadas na matriz, importadores de proteínas mitocondriais, como o complexo TOM (translocase of the outer mitochondrial membrane), e a maquinaria enzimática para a divisão e fusão da organela $(160,161)$.

VDACs, também conhecidas como porinas mitocondriais, são as mais abundantes proteínas integrais de membrana encontradas na membrana externa da mitocôndria (MOM mitochondrial outer membrane) e consideradas um novo alvo para a ação de drogas anti-câncer. Em mamíferos, três genes homólogos codificam três isoformas de VDAC, nomeadas VDAC1, VDAC2 e VDAC3. As três proteínas possuem massa molecular similar (30-35 kDa), compartilham $70 \%$ de identidade e todas as três podem ser encontradas na maioria dos tecidos, sendo a VDAC1 a mais abundante, seguida da VDAC2 e, em menor quantidade, a VDAC3 $(162,163)$.

O específico papel de cada isoforma de VDAC ainda não é claro, embora evidências indiquem diferentes funções fisiológicas (164). Por exemplo, a ausência de VDAC1 causa múltiplos defeitos na atividade do complexo respiratório em músculo cardíaco e esquelético murino, enquanto que em camundongos deficientes em VDAC3, o defeito fica restrito ao coração (165). Embora diferentes estudos apontem outros problemas em camundongos deficientes para VDAC1 e VDAC3, como a inibição de crescimento e esterilidade em machos, os camundongos ainda são viáveis (166). No entanto, embriões de camundongos com deficiência homozigótica para VDAC2 morrem durante o desenvolvimento (167), indicando que VDAC2 pode estar diretamente envolvida em funções vitais.

Enquanto a necrose é um processo acidental e passivo, a apoptose ou morte celular programada é um processo ativo que requer energia para a ativação de uma maquinaria 
intracelular e pode ser dividido em duas vias principais: a via intrínseca ou mitocondrial e a via extrínseca ou citoplasmática $(168,169)$.

A via intrínseca ou mitocondrial da apoptose é finamente controlada pela família de proteínas $\mathrm{Bcl}-2$. Bak (BCl-2 homologous antagonist/killer) pertence a essa família que pode ser dividida em membros anti-apoptóticos (p.ex., Bcl-2, Bcl-XL) e pró-apoptóticos (p.ex., Bak, Bax, Bid, Bad, Bim) (170). Em células saudáveis, Bax (BCl-2-associated $X$ protein) é inativo e predominantemente citosólico. Em contraste, Bak está constitutivamente integrado na membrana externa da mitocôndria como um monômero inativo ou reprimido pela interação com outras proteínas, como a VDAC2 (167). Em células saudáveis, VDAC2 e Bak estão unidas em um complexo onde Bak se apresenta inativada. Quando ativada, Bak está dissociada de VDAC2, formando homo- ou hetero-oligômeros na MOM. Este mecanismo de formação e dissociação do complexo VDAC2-Bak está intimamente relacionado à via mitocondrial da apoptose (171). As proteínas anti-apoptóticas agem bloqueando a liberação de citocromo c e as pró-apoptóticas agem promovendo a liberação de citocromo c. Seguindo o estímulo apoptótico, Bax e Bak (que está inativo ou associado a VDAC2) sofrem mudanças conformacionais, oligomerizam-se e permitem a liberação de citocromo c e Smac/DIABLO por meio da permeabilização da membrana externa da mitocôndria. No citoplasma, o citocromo c se une a Apaf-1, ATP e caspase 9 formando um complexo chamado de Apoptossomo (172).

Já a via extrínseca é mediada pelos chamados "receptores de morte" os quais encontram-se nas superfícies celulares, transmitindo um sinal de morte para o interior da célula. Receptores de morte incluem o gene da superfamília de receptores para o fator de necrose tumoral (RTNF), incluindo RTNF-1, Fas (CD95), DR-4 e DR-5 (receptores TRAIL). Quando um ligante entra em contato com um Fas inativo, induz a formação de um complexo e recruta proteínas adaptadoras FADD intracelulares, que por sua vez recrutam as pró-caspases 8 e 10, formando um complexo indutor da sinalização de morte (DISC). Isso tem efeito auto-proteolítico nas caspases, tornando-as ativas. Uma vez ativada, a caspase 8 cliva as caspases 3,6 e 7, que são caspases efetoras. A caspase 8 interage com a via intrínseca ou mitocondrial através da clivagem de Bid, o que resultará na liberação de citocromo c (173).

Em 2010, Lazarou e colaboradores mostraram resultados de estudos sobre mecanismos que regulam a permeabilização da membrana externa da mitocôndria, processo conhecido como MOMP (mitochondrial outer membrane permeabilization). Neste trabalho mostraram que, em células saudáveis, Bak está presente na membrana externa da mitocôndria em um complexo de aproximadamente $400 \mathrm{kDa}$ e que a liberação de Bak desse complexo coincide com: a ativação de Bak, a permeabilização da membrana externa da mitocôndria, a liberação de citocromo c e que o complexo com Bak é dependente da presença de VDAC2 (174-177).

Em 2013 e 2014, Ma e colaboradores mostraram que, como Bak, uma pequena população de Bax, que constitutivamente reside na mitocôndria, pode também estar presente no complexo de alto peso molecular envolvendo $\operatorname{VDAC2}(171,178)$. Respaldando esses dados, outros estudos recentes contestaram a antiga premissa de que Bax é ativamente deslocado para a MOM sob ativação. Em vez disso, Bax se associa constitutivamente com a mitocôndria, mas é constantemente transportado para o citosol. Sob sinalização apoptótica, esse "retrotransporte" é prejudicado levando ao acúmulo de Bax na mitocôndria (179-181).

Embora os últimos estudos tenham contribuído substancialmente no entendimento do mecanismo de regulação de Bak e observado sua presença em um complexo com VDAC2, pouco se sabe sobre as funções exercidas pelo complexo VDAC2-Bak. Plötz e colaboradores (182), por exemplo, observaram que $\mathrm{Bcl}-\mathrm{x}(\mathrm{S})$ foi capaz de interferir no complexo, deslocando Bak de VDAC2 e induzindo a apoptose em células de melanoma, um tipo de câncer altamente resistente às quimioterapias tradicionais. 


\subsubsection{Contribuições pretendidas.}

Em linhas gerais, essa proposta objetiva a caracterização estrutural, através de criomicroscopia de partículas isoladas (Crio-TEM), da interação entre a porina mitocondrial VDAC2 e a proteína pró-apoptótica Bak, com implicações para o desenvolvimento de novas abordagens terapêuticas em câncer. Foi estabelecido a partir de uma sugestão do Dr. Rodrigo Portugal, pesquisador do Laboratório Nacional de Nanotecnologia (LNNano). Seus esforços estão dedicados no estabelecimento de uma infra-estrutura de equipamentos que permita a formação de uma comunidade interessada em estudos estruturais de proteínas usando Crio-TEM.

Para tanto, pretendemos produzir o complexo estável a partir do ambiente nativo, usando culturas de células humanas estabilizadas, e também recombinante, em modelos de levedura, que se mostraram adequados para os estudos com MPC, acima. A Dra. Sandra Dias coordena as pesquisas nos modelos de células humanas. Uma vez isolado o complexo, como consequência da identificação de detergentes adequados para posterior purificação, este será submetido a estudos de microscopia eletrônica de transmissão, em condições criogênicas, visando a determinação da estrutura tridimensional.

Novamente, esta proposta faz parte de um esforço colaborativo entre pesquisadores do LNBio e LNNano, no sentido de se estabelecer e combinar duas áreas de pesquisa atualmente bastante relevantes e que, provavelmente, representam o futuro da biologia estrutural: proteínas de membrana e criomicroscopia eletrônica de partículas isoladas. Apesar de vários esforços individuais de pesquisadores na região, ambas as áreas ainda estão subdesenvolvidas na América Latina, como um todo. É principalmente neste sentido que pretendemos colaborar.

Como mencionado nas sessões anteriores, ao longo dos últimos dois anos, com financiamento FAPESP, meu laboratório tem adquirido experiência na produção e purificação de proteínas transmembranares, contando principalmente com a colaboração constante da equipe de especialista do Membrane Protein Laboratory (MPL). Acredito que a experiência adquirida até então nos permitirá extrair e purificar o complexo VDAC2:Bak em quantidade e condições adequadas para os estudos estruturais.

Atualmente, temos um pós-doutorando desenvolvendo este projeto. Já conseguimos expressar e purificar parcialmente VDAC2 sozinha e também co-expressar, e confirmar a localização mitocondrial de seu complexo com Bak. Mais ainda, recentemente adquirimos a capacidade técnica para a produção de nano-discos, visando posterior reconstituição das proteínas purificadas nestes. Nano-discos constituem uma técnica de fronteira e são cruciais para a remoção completa de detergentes para os experimentos de Crio-TEM. Meu Auxílio regular FAPESP vigente (2017/11766-5) financia estas pesquisas. 


\subsection{Fator de transcrição MondoA (2013 - presente)}

O fator de transcrição MondoA foi inicialmente descrito há pouco mais de 10 anos pelo laboratório do Dr. Donald Ayer, da Universidade de Utah (183), nosso colaborador desse projeto. Seu laboratório está interessado em estudar a habilidade das células em sentir e responder à mudança dos níveis de nutrientes no microambiente celular, em especial com relação ao açúcar glicose.

Sabe-se hoje que dois fatores transcrição, MondoA e seu parálogo ChREBP, agem como os principais biossensores transcricionais de glicose $(184,185)$. Estas proteínas são originalmente localizadas no citoplasma das células em condições de baixa glicose, mas acumulam-se no núcleo realizando a transativação de genes alvo em condições de aumento de concentração de glicose (186-188). ChREBP é expresso predominantemente em células hepáticas e regula a expressão de genes envolvidos na conversão de glicose para lipídeos, com fins de armazenamento de energia e crescimento celular (189-191) enquanto MondoA é expressa predominantemente em células musculares esqueléticas e regula a transcrição de genes da via glicolítica (188).

A translocação nuclear de MondoA e ChREBP, e a suas ligações aos elementos responsivos, estão associadas à dimerização obrigatória com o parceiro Mlx, um fator de transcrição da família Max, expresso constitutivamente em todos os tecidos. MondoA, ChREBP e Mlx contém o motivo basic helix-loop-helix leucine zipper (bHLH) de ligação a DNA, além do domínio de localização citoplasmática (DCD) que deve ser mascarado anteriormente à translocação nuclear $(192,193)$. Essas regiões são esquematizadas na figura 12.

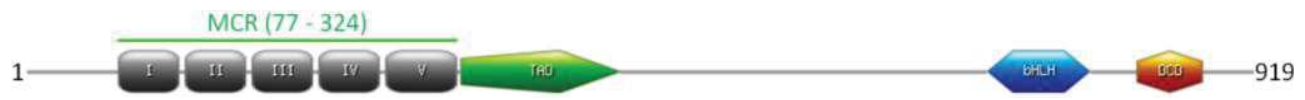

Figura 12: As atividade glicose-dependentes de MondoA requerem os domínios MCR e bHLHZip. Adaptado de (193).

Dada a importância de MondoA e ChREBP para o metabolismo de glicose da célula e uma possível relação direta com o fator de transcrição e oncongene Myc, especula-se que MondoA possa cooperar com este último diretamente no processo de adaptação metabólica de tumores dirigidos por Myc (194-197).

Uma vez que MondoA e ChREBP são principalmente proteínas citoplasmáticas, foi surpreendente descobrir que simplesmente prendê-las dentro do núcleo em condições de baixa concentração de glicose não é suficiente para aumentar a expressão de seus genes alvos (184, 185). Em contraste, construções que não possuem a região $\mathrm{N}$-terminal são capazes de constitutivamente transativar genes em meios tanto com baixa quanto alta concentração de glicose $(190,192,198,199)$. Estes resultados indicaram que sequências do domínio N-terminal destas proteínas contribuem para a transativação em resposta à glicose $(192,198)$. Sabe-se hoje que existem cinco regiões conservadas na porção N-terminal da MondoA, chamadas de Mondo Conserved Regions (MCRI-V), mais especificamente entre os resíduos 77 e 324 (que possui um total de 919 aminoácidos). 0 tamanho, a sequência de aminoácidos e as distâncias entre MCRII, MCRIII e MCRIV em MondoA e ChREBP são bem conservados, o que sugere que estes possam agir como um módulo funcional, enquanto que as regiões MCRI e MCRV variam bastante entre essas duas proteínas (200). MCRII contém um sinal de exportação nuclear (NLS - Nuclear Export Signal), quase idêntico ao motivo canônico NLS LxxLFxxLSV, onde x é qualquer aminoácido. Em contraste, MCRIV em ChREBP contém um sinal de localização nuclear (NLS - Nuclear Location Signal - bipartido) que medeia sua entrada no núcleo $(188,201)$. O MCRIII por sua vez contém um motivo de ligação canônico à proteína 14-3-3 a qual está envolvida na retenção 
citoplasmática, transativação e ao exporte nuclear de MondoA e ChREBP $(190,192,202)$. As funções de MCRI e MCRV não são tão claras, embora MCRI pareça ser necessário para transativação gênica dependente de glicose no ChREBP (203).

Adicionalmente, deleções e mutações demonstram que cada MCR parece ter funções múltiplas e geramente opostas. MCRI é necessário para a resposta à glicose, uma vez que alterações nesta região (MondoA: $\Delta 1-100$, His78Ala/His81Ala/His88Ala ou em ChREBP: $\Delta 1-58$ ou $\triangle 1-71)$ são capazes de bloquear transativação na presença de altos níveis de glicose (184, 190, 192, 203). Da mesma forma, a alteração da sequência NES em MCRII (MondoA: Phe130Ala, Met133Ala, 4 125-137 ou em ChREBP: Leu89Ala, Phe90Ala) aumenta levemente os níveis de transativação, enquanto outras mutações no MCRII (ChREBP: Leu86Aala/Leu93Aala, Tyr85Aala, Leu95Aala, $472-99 ;$ MondoA: Leu129Aala) a bloqueia completamente $(193,204,205)$. Em MCRIII, interferências no sítio de ligação à 14-3-3 (MondoA: Ile166Ala/Trp167Ala/Arg168Ala; ChREBP: Arg128Ala, Trp130Ala) inibem a transativaçã. Curiosamente, as mudanças dentro MCRIV têm efeitos ainda mais diversificados. Deleções que eliminam o NLS (ChREBP: $\triangle 141-197$, $\Delta 158-181)$ previnem a transativação $(188,200)$. Em adição, a deleção $\Delta 144-196$ em ChREBP reduz a função de transativação além de eliminar a inibição dependente de glicose (206), enquanto o triplo-mutante Tyr210Asp/Trp211Asp/Lys212A em MondoA aumenta o acúmulo nuclear e transativação (193). Enquanto que a MCRV parece não mostrar efeitos repressivos, a deleção de MCRI-IV (MondoA: $\Delta 282-324$; ChREBP: Tyr275Ala/Val276Ala/Gly277Ala, Leu289Ala/GIn290Ala/Pro291Ala) levam à um aumento em seu acúmulo nuclear de MondoA e consequente aumento dos níveis de transativação $(193,199)$. Embora as condições celulares, mutações sítio-dirigidas e ensaios com gene repórter variem bastante entre estes estudos, em resumo fica claro que as regiões $M C R$ cooperativamente reprimem e ativam a função de transativação de MondoA e ChREBP em resposta à glicose.

Evidências mais recentes mostram que a ativação da MondoA e ChREBP é dependente da fosforilação de glicose por hexoquinase, a qual metaboliza esse açúcar para formar glicose-6fosfato-(G6P) $(193,201,206)$. Tratamento celular com 2-deoxiglicose (2-DG), que é um análogo da glicose que pode ser fosforilado, porém não mais catabolizado, promove acúmulo nuclear de MondoA, aumenta a ocupação do promotor e recruta histona $\mathrm{H} 3$ acetiltransferase, ativando assim a transcrição de genes alvos de MondoA (193). Da mesma forma, experimentos de doseresposta de 2-DG aumentaram a capacidade de transativação de GAL4-ChREBP, enquanto que tanto o tratamento com o inibidor de hexoquinase d-Manoeptulose quanto a superexpressão das enzimas glicolíticas PFK1 e PFK2, as quais metabolizam o G6P gerado pela hexokinase, diminuem os níveis de atividade de ChREBP (206). Isto sugere que a ativação de MondoA e ChREBP é invocada diretamente pela fosforilação de glicose, podendo ocorrer a partir de mecanismo alostérico acionado pela ligação direta do G6P a estas proteínas, ou a partir de alguma cascata de sinalização mediada por G6P, ou ambos. De qualquer maneira, essa seria a primeira comprovação de regulação direta de transcrição gênica através de produtos metabólicos.

\subsubsection{Contribuições pretendidas.}

No final de final de 2012, por intermédio do Dr. Chi van Dang, nosso colaborador há longo tempo no projeto das glutaminase, fomos apresentados ao Dr. Don Ayer. O Dr. Ayer, descobridor de MondoA e especialista em biologia celular, estava procurando um colaborador em bioquímica para produzir e purificar essa proteína a partir de fonte natural ou recombinante. Seu objetivo era o de confirmar in vitro a ligação direta entre MondoA e G6P, o que representaria o primeiro exemplo na literatura de regulação da expressão gênica por um metabólito.

Por comunicação pessoal do Dr. Ayer, de acordo com evidências em célula, sabíamos que a região $\mathrm{N}$-terminal de MondoA (chamada de MCR) seria capaz de se ligar diretamente a G6P, 
porém a sequência mínima necessária para tal ainda não estava completamente determinada. O objetivo de nossa colaboração e o que propusemos para um projeto de mestrado FAPESP sob minha orientação, foi o planejamento de uma série de construções abrangendo as regiões MCR I a V, com foco na produção heteróloga, cristalização e posterior resolução estrutural dessa região em complexo com G6P.

Mesmo após um trabalho exaustivo da aluna de mestrado responsável pelo projeto, poir quase um ano e meio (entre 2013 e 2014), testando dezenas de construções alternativas, em vários vetores de expressão recombinante em bactéria e levedura, não obtivemos sucesso. TODAS as construções foram sempre insolúveis. Em função desse insucesso, o projeto da aluna foi substituído perante a FAPESP, e se tornou um doutorado direto em glutaminases.

Todavia, não desistimos de MondoA. Em uma das visitas do Dr. Wyatt Yue (SGC, Oxford), ao Brasil, em 2015, acordamos em uma estratégia alternativa. O laboratório do Dr. Yue é especialista em expressão recombinante de proteínas, em larga escala, em sistema de células de insetos e também mamíferos. Entre 2015 e 2016, foram geradas novas construções de MCR de MondoA, que se mostraram adequadamente solúveis e puderam ser purificadas, pelo menos parcialmente.

Com esperanças renovadas, em janeiro de 2017, as novas construções, especialmente aquelas que funcionaram para expressão recombinante em células humanas HEK293, foram encaminhadas ao laboratório do Dr. Ayer, nos EUA, que está conduzindo os ensaios bioquímicos. De acordo com comunicação recente do Dr. Ayer, resultados inéditos devem ser gerados e submetidos para publicação até o final de 2017. Esperamos, de fato, confirmar a interação entre MondoA e G6P. A natureza de tal interação, entre um fator de transcrição e um metabólito, continua inédita, mesmo depois desses anos. Da minha parte, tenho interesse adicional em continuar tais estudos em meu laboratório, através do recrutamento de um novo aluno; principalmente, prevejo o benefício em estabelecer sistemas de expressão recombinante em Sf9 (inseto) e HEK293. Nosso laboratório ainda não domina estas tecnologias. 


\section{CONSIDERAÇÕES FINAIS}

De acordo com o exposto acima, espero ter sistematizado adequadamente a coerência e as motivações da minha linha de pesquisa. Escolhi particularmente estes trabalhos, pois foram (e são) realizados sob minha coordenação direta, em colaboração ativa com colegas pesquisadores (nacionais e internacionais) e estudantes. Todavia, entendo que tão importante quanto as pesquisas propriamente ditas, são as circunstâncias sob as quais estas foram idealizadas e implementadas. Por isso, apresentei um breve histórico destas circunstâncias.

Como descrito anteriormente, meu objetivo como pesquisador é o de procurar estar sempre alinhado com as fronteiras do tema de minha pesquisa e do desenvolvimento tecnológico da área. A instituição na qual atualmente me insiro, o CNPEM, é um centro de pesquisas qualificado pelo Ministério da Ciência, Tecnologia, Inovações e Comunicações. Tem a missão de promover os desenvolvimentos científico e tecnológico, bem como a inovação no país. É de acordo com esta missão que procurei, ao longo desses 8 anos como pesquisador independente, sustentar uma linha de pesquisa atual e relevante. Por isso, devido à minha formação em biologia estrutural, recentemente estabeleci os projetos colaborativos em proteínas de membrana, combinando cristalografia por difração de raios $\mathrm{X}$ e crio-microscopia eletrônica. Particularmente, entendo que deva haver um compromisso alinhado da comunidade científica em quere usar ao máximo a infraestrutura que o país oferece, principalmente quando o laboratório síncrotron de quarta geração, Sirius, estiver em pleno funcionamento.

Intrinsecamente associado a esses elementos da pesquisa científica, está a capacidade de captação independente de recursos perante agências de fomento. Até o momento, são quatros Auxílio Regulares FAPESP dentro do tema, além de um Auxílio Universal (faixa A) do CNPq.

Todavia, desde o início, procurei também exercer ativamente atividades de docência, através de credenciamentos como orientador externo junto à programas de pós-graduação da Unicamp. Principalmente, junto ao Instituto de Biologia desta universidade, coordenei e ministrei diversas disciplinas de acordo os calendários e participei de diversas comissões. Principalmente, atuei, e ainda atuo, ativamente na orientação de alunos de pós-graduação. Até o momento, são 18 bolsas da FAPESP, concluídas ou em andamento, sob minha orientação/supervisão. Até o momento, concluí a orientação de duas dissertações de metrado e três teses de doutorado.

A área de metabolismo tumoral continua cada vez mais relevante. A absorção e o metabolismo "desregulados" de nutrientes se estendem muito além da glicose e da glutamina, embora essas tenham sido as vias mais caracterizadas hoje. A aquisição de lipídios ou ácidos graxos, outros aminoácidos e o acetato extracelular, e sua contribuição e necessidade para a tumorigênese são assuntos de pesquisas recentes (5). As perspectivas são excelentes e, eventualmente, estes podem se tornar novos alvos em nossos estudos. 


\section{REFERÊNCIAS}

1. Hanahan, D., and Weinberg, R. A. (2011) Hallmarks of Cancer: The Next Generation. Cell. 144, 646-674

2. Jafri, M. A., Ansari, S. A., Alqahtani, M. H., and Shay, J. W. (2016) Roles of telomeres and telomerase in cancer, and advances in telomerase-targeted therapies. Genome Med. 8, 69

3. DeBerardinis, R. J., Lum, J. J., Hatzivassiliou, G., and Thompson, C. B. (2008) The Biology of Cancer: Metabolic Reprogramming Fuels Cell Growth and Proliferation. Cell Metab. 7, 11-20

4. Warburg, O., Wind, F., and Negelein, E. (1927) The Metabolism of Tumors in the Body. J. Gen. Physiol. 8, 519-30

5. Pavlova, N. N., and Thompson, C. B. (2016) The Emerging Hallmarks of Cancer Metabolism. Cell Metab. 23, 27-47

6. Szablewski, L. (2013) Expression of glucose transporters in cancers. Biochim. Biophys. Acta-Rev. Cancer. 1835, 164-169

7. Kunkel, M., Reichert, T. E., Benz, P., Lehr, H.-A., Jeong, J.-H., Wieand, S., Bartenstein, P., Wagner, W., and Whiteside, T. L. (2003) Overexpression of Glut-1 and increased glucose metabolism in tumors are associated with a poor prognosis in patients with oral squamous cell carcinoma. Cancer. 97, 1015-1024

8. Cho, H., Lee, Y. S., Kim, J., Chung, J.-Y., and Kim, J.-H. (2013) Overexpression of Glucose Transporter-1 (GLUT-1) Predicts Poor Prognosis in Epithelial Ovarian Cancer. Cancer Invest. 31, 607-615

9. Younes, M., Juarez, D., Lechago, L. V, and Lerner, S. P. (2001) Glut 1 expression in transitional cell carcinoma of the urinary bladder is associated with poor patient survival. Anticancer Res. 21, 575-578

10. Hay, N. (2016) Reprogramming glucose metabolism in cancer: can it be exploited for cancer therapy? Nat. Rev. Cancer. 16, 635-649

11. Eagle, H. (1955) The minimum vitamin requirements of the $L$ and HeLa cells in tissue culture, the production of specific vitamin deficiencies, and their cure. J. Exp. Med. 102, 595-600

12. DeBerardinis, R. J., and Cheng, T. (2010) Q's next: the diverse functions of glutamine in metabolism, cell biology and cancer. Oncogene. 29, 313-324

13. Krebs, H. A. (1935) Metabolism of amino-acids: The synthesis of glutamine from glutamic acid and ammonia, and the enzymic hydrolysis of glutamine in animal tissues. Biochem. J. 29, 195169

14. Martín-Rufián, M., Tosina, M., Campos-Sandoval, J. A., Manzanares, E., Lobo, C., Segura, J. A., Alonso, F. J., Matés, J. M., and Márquez, J. (2012) Mammalian glutaminase Gls2 gene encodes two functional alternative transcripts by a surrogate promoter usage mechanism. PLoS One. 7, e38380

15. Curthoys, N. P., and Watford, M. (1995) Regulation of glutaminase activity and glutamine metabolism. Annu. Rev. Nutr. 15, 133-159

16. Aledo, J. C., Gómez-Fabre, P. M., Olalla, L., and Márquez, J. (2000) Identification of two human glutaminase loci and tissue-specific expression of the two related genes. Mamm. Genome. 11, 1107-1110

17. Lohmann, R., Souba, W. W., and Bode, B. P. (1999) Rat liver endothelial cell glutamine transporter and glutaminase expression contrast with parenchymal cells. Am. J. Physiol. 276, G743-G750

18. Elgadi, K. M., Meguid, R. A., Qian, M., Souba, W. W., and Abcouwer, S. F. (1999) Cloning and analysis of unique human glutaminase isoforms generated by tissue-specific alternative splicing. Physiol. Genomics. 1, 51-62 
19. Gómez-Fabre, P. M., ALEDO, J. C., Del Castillo-Olivares, A., Alonso, F. J., Núñez De Castro, I., Campos, J. A., and Márquez, J. (2000) Molecular cloning, sequencing and expression studies of the human breast cancer cell glutaminase. Biochem. J. 345, 365-375

20. Smith, M., and Watford, M. (1990) Molecular cloning of a cDNA for rat hepatic glutaminase. Sequence similarity to kidney-type glutaminase. J. Biol. Chem. 265, 10631-10636

21. Porter, L. D., Ibrahim, H., Taylor, L., and Curthoys, N. P. (2002) Complexity and species variation of the kidney-type glutaminase gene. Physiol. Genomics. 9, 157-166

22. Pérez-Gómez, C., Matés, J. M., Gómez-Fabre, P. M., del Castillo-Olivares, A., Alonso, F. J., and Márquez, J. (2003) Genomic organization and transcriptional analysis of the human Iglutaminase gene. Biochem. J. 370, 771-784

23. Shapiro, R. A., Farrell, L., Srinivasan, M., and Curthoyss, N. P. (1991) Isolation, Characterization, and in Vitro Expression of a cDNA That Encodes the Kidney Isoenzyme of the Mitochondrial Glutaminas. J. Biol. Chem. 266, 18792-18796

24. Olalla, L., Aledo, J. C., Bannenberg, G., and Márquez, J. (2001) The C-terminus of human glutaminase L mediates association with PDZ domain-containing proteins. FEBS Lett. 488, 116122

25. Colombo, S. L., Palacios-Callender, M., Frakich, N., De Leon, J., Schmitt, C. A., Boorn, L., Davis, N., and Moncada, S. (2010) Anaphase-promoting complex/cyclosome-Cdh1 coordinates glycolysis and glutaminolysis with transition to $\mathrm{S}$ phase in human T lymphocytes. Proc. Natl. Acad. Sci. U. S. A. 107, 18868-73

26. Márquez, J., López de la Oliva, A. R., Matés, J. M., Segura, J. A., and Alonso, F. J. (2006) Glutaminase: A multifaceted protein not only involved in generating glutamate. Neurochem. Int. 48, 465-471

27. Brown, G., Singer, A., Proudfoot, M., Skarina, T., Kim, Y., Chang, C., Dementieva, I., Kuznetsova, E., Gonzalez, C. F., Joachimiak, A., Savchenko, A., and Yakunin, A. F. (2008) Functional and Structural Characterization of Four Glutaminases from Escherichia coli and Bacillus subtilis + . Biochemistry. 47, 5724-5735

28. Curthoys, P., Kuhlenschmidt, T., Weiss, R. F., and Godfrey, S. S. (1976) Phosphate-Dependent Activity Glutaminase from Rat Kidney and Identity with Glutaminase in Response to Acidosis from Other Tissues'. Arch. Biochem. Biophys. 167, 162-167

29. Cassago, A., Ferreira, A. P. S., Ferreira, I. M., Fornezari, C., Gomes, E. R. M., Greene, K. S., Pereira, H. M., Garratt, R. C., Dias, S. M. G., and Ambrosio, A. L. B. (2012) Mitochondrial localization and structure-based phosphate activation mechanism of Glutaminase $\mathrm{C}$ with implications for cancer metabolism. Proc. Natl. Acad. Sci. 109, 1092-1097

30. Campos-Sandoval, J. a. J. A. J. a., Lopez de la Oliva, A. R., Lobo, C., Segura, J. a., Mates, J. M., Alonso, F. J., Marquez, J., López de la Oliva, A. R., Lobo, C., Segura, J. a., Matés, J. M., Alonso, F. J., and Márquez, J. (2007) Expression of functional human glutaminase in baculovirus system: Affinity purification, kinetic and molecular characterization. Int. J. Biochem. Cell Biol. 39, 765773

31. Kovacevic, Z., and McGivan, J. D. (1983) Mitochondrial metabolism of glutamine and glutamate and its physiological significance. Physiol. Rev. 63, 547-605

32. Shapiro, R. a, Morehouse, R. F., and Curthoys, N. P. (1982) Inhibition by glutamate of phosphatedependent glutaminase of rat kidney. Biochem. J. 207, 561-6

33. Olsen, B. R., Svenneby, G., Kvamme, E., Tveit, B., and Eskeland, T. (1970) Formation and ultrastructure of enzymically active polymers of pig renal glutaminase. J. Mol. Biol. 52, 239-245

34. Godfrey, S., Kuhlenschmidt, T., and Curthoys, P. (1977) Correlation between activation and dimer formation of rat renal phosphate-dependent glutaminase. J. Biol. Chem. 252, 1927-1931

35. Ferreira, A. P. S., Cassago, A., Gonçalves, K. de A., Dias, M. M., Adamoski, D., Ascenção, C. F. R., Honorato, R. V., de Oliveira, J. F., Ferreira, I. M., Fornezari, C., Bettini, J., Oliveira, P. S. L., Paes 
Leme, A. F., Portugal, R. V., Ambrosio, A. L. B., and Dias, S. M. G. (2013) Active Glutaminase C Self-assembles into a Supratetrameric Oligomer That Can Be Disrupted by an Allosteric Inhibitor. J. Biol. Chem. 288, 28009-28020

36. Robinson, M. M., McBryant, S. J., Tsukamoto, T., Rojas, C., Ferraris, D. V, Hamilton, S. K., Hansen, J. C., and Curthoys, N. P. (2007) Novel mechanism of inhibition of rat kidney-type glutaminase by bis-2-(5-phenylacetamido-1,2,4-thiadiazol-2-yl)ethyl sulfide (BPTES). Biochem. J. 406, 407-14

37. Thangavelu, K., Pan, C. Q., Karlberg, T., Balaji, G., Uttamchandani, M., Suresh, V., Schüler, H., Low, B. C., and Sivaraman, J. (2012) Structural basis for the allosteric inhibitory mechanism of human kidney-type glutaminase (KGA) and its regulation by Raf-Mek-Erk signaling in cancer cell metabolism. Proc. Natl. Acad. Sci. U. S. A. 109, 7705-10

38. Delabarre, B., Gross, S., Fang, C., Gao, Y., Jha, A., Jiang, F., Song J., J., Wei, W., Hurov, J. B., Song J, J., Wei, W., and Hurov, J. B. (2011) Full-length human glutaminase in complex with an allosteric inhibitor. Biochemistry. 50, 10764-10770

39. Bramlett, K. S., Wu, Y., and Burris, T. P. (2001) Ligands specify coactivator nuclear receptor (NR) box affinity for estrogen receptor subtypes. Mol Endocrinol. 15, 909-22.

40. Stevens, F. C. (1983) Calmodulin: an introduction. Can. J. Biochem. cell Biol. 61, 906-10

41. Gomes, A. V, Potter, J. D., and Szczesna-Cordary, D. (2002) The role of troponins in muscle contraction. IUBMB Life. 54, 323-333

42. Lewit-Bentley, A., and Réty, S. (2000) EF-hand calcium-binding proteins. Curr. Opin. Struct. Biol. 10, 637-643

43. Pfleger, C. M., and Kirschner, M. W. (2000) The KEN box: an APC recognition signal distinct from the D box targeted by Cdh1. Genes Dev. 14, 655-65

44. Kornau, H.-C., Schenker, L. T., Kennedy, M. B., and Seeburg, P. H. (1995) Domain Interaction between NMDA Receptor Subunits and the Postsynaptic Density Protein PSD-95. Source Sci. New Ser. 269, 1737-1740

45. Márquez, J., Tosina, M., de la Rosa, V., Segura, J. A., Alonso, F. J., Matés, J. M., and CamposSandoval, J. A. (2009) New insights into brain glutaminases: Beyond their role on glutamatergic transmission. Neurochem. Int. 55, 64-70

46. Bergström, J., Fürst, P., Norée, L. O., and Vinnars, E. (1974) Intracellular free amino acid concentration in human muscle tissue. J. Appl. Physiol. 36, 693-7

47. DeBerardinis, R. J., and Cheng, T. (2010) Q's next: the diverse functions of glutamine in metabolism, cell biology and cancer. Oncogene. 29, 313-324

48. Levine, A. J., and Puzio-Kuter, A. M. (2010) The Control of the Metabolic Switch in Cancers by Oncogenes and Tumor Suppressor Genes. Science (80-. ). 330, 1340-1344

49. Yelamanchi, S. D., Jayaram, S., Thomas, J. K., Gundimeda, S., Khan, A. A., Singhal, A., Keshava Prasad, T. S., Pandey, A., Somani, B. L., and Gowda, H. (2016) A pathway map of glutamate metabolism. J. Cell Commun. Signal. 10, 69-75

50. Owen, O. E., Kalhan, S. C., and Hanson, R. W. (2002) The key role of anaplerosis and cataplerosis for citric acid cycle function. J. Biol. Chem. 277, 30409-30412

51. Altman, B. J., Stine, Z. E., and Dang, C. V (2016) From Krebs to clinic: glutamine metabolism to cancer therapy. Nat. Rev. Cancer. 16, 619-634

52. Van Den Heuvel, A. P. J., Jing, J., Wooster, R. F., and Bachman, K. E. (2012) Analysis of glutamine dependency in non-small cell lung cancer: GLS1 splice variant GAC is essential for cancer cell growth. Cancer Biol. Ther. 13, 1185-1194

53. Timmerman, L. A., Holton, T., Yuneva, M., Louie, R. J., Padró, M., Daemen, A., Hu, M., Chan, D. A., Ethier, S. P., van'tVeer, L. J., Polyak, K., McCormick, F., Gray, J. W., Padr??, M., Daemen, A., Hu, M., Chan, D. A., Ethier, S. P., van'tVeer, L. J., Polyak, K., McCormick, F., and Gray, J. W. (2013) Glutamine Sensitivity Analysis Identifies the xCT Antiporter as a Common Triple-Negative Breast 
54. Xia, Z., Donehower, L. A., Cooper, T. A., Neilson, J. R., Wheeler, D. A., Wagner, E. J., and Li, W. (2014) Dynamic analyses of alternative polyadenylation from RNA-seq reveal a 3'-UTR landscape across seven tumour types. Nat. Commun. 5, 5274

55. Redis, R. S., Vela, L. E., Lu, W., Ferreira de Oliveira, J., Ivan, C., Rodriguez-Aguayo, C., Adamoski, D., Pasculli, B., Taguchi, A., Chen, Y., Fernandez, A. F., Valledor, L., Van Roosbroeck, K., Chang, S., Shah, M., Kinnebrew, G., Han, L., Atlasi, Y., Cheung, L. H., Huang, G. Y., Monroig, P., Ramirez, M. S., Catela Ivkovic, T., Van, L., Ling, H., Gafà, R., Kapitanovic, S., Lanza, G., Bankson, J. A., Huang, P., Lai, S. Y., Bast, R. C., Rosenblum, M. G., Radovich, M., Ivan, M., Bartholomeusz, G., Liang, H., Fraga, M. F., Widger, W. R., Hanash, S., Berindan-Neagoe, I., Lopez-Berestein, G., Ambrosio, A. L. B. B., Gomes Dias, S. M., and Calin, G. A. (2016) Allele-Specific Reprogramming of Cancer Metabolism by the Long Non-coding RNA CCAT2. Mol. Cell. 61, 520-534

56. Suzuki, S., Tanaka, T., Poyurovsky, M. V., Nagano, H., Mayama, T., Ohkubo, S., Lokshin, M., Hosokawa, H., Nakayama, T., Suzuki, Y., Sugano, S., Sato, E., Nagao, T., Yokote, K., Tatsuno, I., and Prives, C. (2010) Phosphate-activated glutaminase (GLS2), a p53-inducible regulator of glutamine metabolism and reactive oxygen species. Proc. Natl. Acad. Sci. U. S. A. 107, 74617466

57. Hu, W., Zhang, C., Wu, R., Sun, Y., Levine, A., and Feng, Z. (2010) Glutaminase 2, a novel p53 target gene regulating energy metabolism and antioxidant function. Proc. Natl. Acad. Sci. U. S. A. $107,7455-7460$

58. Szeliga, M., Bogacińska-Karaś, M., Rózycka, A., Hilgier, W., Marquez, J., Albrecht, J., Różycka, A., Hilgier, W., Marquez, J., and Albrecht, J. (2014) Silencing of GLS and overexpression of GLS2 genes cooperate in decreasing the proliferation and viability of glioblastoma cells. Tumor Biol. 35, 1855-1862

59. Szeliga, M., and Albrecht, J. (2015) Opposing roles of glutaminase isoforms in determining glioblastoma cell phenotype. Neurochem. Int. 88, 6-9

60. Liu, J., Zhang, C., Lin, M., Zhu, W., Liang, Y., Hong, X., Zhao, Y., Young, K. H., Hu, W., and Feng, Z. (2014) Glutaminase 2 negatively regulates the PI3K / AKT signaling and shows tumor suppression activity in human hepatocellular carcinoma ABSTRACT : Oncotarget. 5, 2635-2647

61. Zhang, C., Liu, J., Zhao, Y., Yue, X., Zhu, Y., Wang, X., Wu, H., Blanco, F., Li, S., Bhanot, G., Haffty, B. G., Hu, W., and Feng, Z. (2016) Glutaminase 2 is a novel negative regulator of small GTPase Rac1 and mediates p53 function in suppressing metastasis. Elife. 5, 1-20

62. Kuo, T. C., Chen, C. K., Hua, K. T., Yu, P., Lee, W. J., Chen, M. W., Jeng, Y. M., Chien, M. H., Kuo, K. T., Hsiao, M., and Kuo, M. L. (2016) Glutaminase 2 stabilizes Dicer to repress Snail and metastasis in hepatocellular carcinoma cells. Cancer Lett. 383, 1-13

63. Wang, Y., and Shang, Y. (2013) Epigenetic control of epithelial-to-mesenchymal transition and cancer metastasis. Exp. Cell Res. 319, 160-169

64. Xiang, L., Xie, G., Liu, C., Zhou, J., Chen, J., Yu, S., Li, J., Pang, X., Shi, H., and Liang, H. (2013) Knock-down of glutaminase 2 expression decreases glutathione, NADH, and sensitizes cervical cancer to ionizing radiation. Biochim. Biophys. Acta - Mol. Cell Res. 1833, 2996-3005

65. Qing, G., Li, B., Vu, A., Skuli, N., Walton, Z. E., Liu, X., Mayes, P. A., Wise, D. R., Thompson, C. B., Maris, J. M., Hogarty, M. D., and Simon, M. C. (2012) ATF4 Regulates MYC-Mediated Neuroblastoma Cell Death upon Glutamine Deprivation. Cancer Cell. 22, 631-644

66. Xiao, D., Ren, P., Su, H., Yue, M., Xiu, R., Hu, Y., Liu, H., and Qing, G. (2015) Myc promotes glutaminolysis in human neuroblastoma through direct activation of glutaminase 2 . Oncotarget. 6, 40655-66

67. Wise, D. R., DeBerardinis, R. J., Mancuso, A., Sayed, N., Zhang, X.-Y., Pfeiffer, H. K., Nissim, I., Daikhin, E., Yudkoff, M., McMahon, S. B., and Thompson, C. B. (2008) Myc regulates a transcriptional program that stimulates mitochondrial glutaminolysis and leads to glutamine addiction. Proc. Natl. Acad. Sci. U. S. A. 105, 18782-18787 
68. Gaglio, D., Metallo, C. M., Gameiro, P. A., Hiller, K., Danna, L. S., Balestrieri, C., Alberghina, L., Stephanopoulos, G., and Chiaradonna, F. (2011) Oncogenic K-Ras decouples glucose and glutamine metabolism to support cancer cell growth. Mol. Syst. Biol. 7, 523

69. Wang, J.-B., Erickson, J. W., Fuji, R., Ramachandran, S., Gao, P., Dinavahi, R., Wilson, K. F., Ambrosio, A. L. B., Dias, S. M. G., Dang, C. V., and Cerione, R. A. (2010) Targeting Mitochondrial Glutaminase Activity Inhibits Oncogenic Transformation. Cancer Cell. 18, 207-219

70. Lee, S. Y., Jeon, H. M., Ju, M. K., Jeong, E. K., Kim, C. H., Park, H. G., Han, S. I., and Kang, H. S. (2016) Dlx-2 and glutaminase upregulate epithelial-mesenchymal transition and glycolytic switch. Oncotarget. 7, 7925-39

71. Garcia-Cao, I., Song, M. S., Hobbs, R. M., Laurent, G., Giorgi, C., De Boer, V. C. J., Anastasiou, D., Ito, K., Sasaki, A. T., Rameh, L., Carracedo, A., Vander Heiden, M. G., Cantley, L. C., Pinton, P., Haigis, M. C., and Pandolfi, P. P. (2012) Systemic elevation of PTEN induces a tumor-suppressive metabolic state. Cell. 149, 49-62

72. Chang, T.-C., Yu, D., Lee, Y.-S., Wentzel, E. A., Arking, D. E., West, K. M., Dang, C. V, ThomasTikhonenko, A., and Mendell, J. T. (2008) Widespread microRNA repression by Myc contributes to tumorigenesis. Nat. Genet. 40, 43-50

73. Eilers, M., and Eisenman, R. N. (2008) Myc's broad reach. Genes Dev. 22, 2755-2766

74. Gao, P., Tchernyshyov, I., Chang, T.-C., Lee, Y.-S., Kita, K., Ochi, T., Zeller, K. I., De Marzo, A. M., Van Eyk, J. E., Mendell, J. T., and Dang, C. V (2009) c-Myc suppression of miR-23a/b enhances mitochondrial glutaminase expression and glutamine metabolism. Nature. 458, 762-5

75. Chhabra, R., Dubey, R., and Saini, N. (2010) Cooperative and individualistic functions of the microRNAs in the miR-23a 27a 24-2 cluster and its implication in human diseases. Mol. Cancer. 9, 232

76. Rathore, M. G., Saumet, A., Rossi, J.-F., de Bettignies, C., Tempé, D., Lecellier, C.-H., and Villalba, M. (2012) The NF-kB member p65 controls glutamine metabolism through miR-23a. Int. J. Biochem. Cell Biol. 44, 1448-1456

77. Weinberg, F., Hamanaka, R., Wheaton, W. W., Weinberg, S., Joseph, J., Lopez, M., Kalyanaraman, B., Mutlu, G. M., Budinger, G. R. S., and Chandel, N. S. (2010) Mitochondrial metabolism and ROS generation are essential for Kras-mediated tumorigenicity. Proc. Natl. Acad. Sci. U. S. A. 107, 8788-93

78. Son, J., Lyssiotis, C. a, Ying, H., Wang, X., Hua, S., Ligorio, M., Perera, R. M., Ferrone, C. R., Mullarky, E., Shyh-Chang, N., Kang, Y., Fleming, J. B., Bardeesy, N., Asara, J. M., Haigis, M. C., DePinho, R. a, Cantley, L. C., and Kimmelman, A. C. (2013) Glutamine supports pancreatic cancer growth through a KRAS-regulated metabolic pathway. Nature. 496, 101-5

79. Lukey, M. J., Greene, K. S., Erickson, J. W., Wilson, K. F., and Cerione, R. A. (2016) The oncogenic transcription factor c-Jun regulates glutaminase expression and sensitizes cells to glutaminasetargeted therapy. Nat. Commun. 7, 11321

80. Pascoal, C. C., Islam, Z., Adamoski, D., Ferreira, I. M., Righetto, R. D., Bettini, J., Portugal, R. V., Yue, W. W., Gonzalez, A., Dias, S. M. G., Ambrosio, A. L. B., Pasquali, C. C., Islam, Z., Adamoski, D., Ferreira, I. M., Righeto, R. D., Bettini, J., Portugal, R. V., Yue, W. W., Gonzalez, A., Dias, S. M. G., and Ambrosio, A. L. B. (2017) The origin and evolution of human glutaminases and their atypical C-terminal ankyrin repeats. J. Biol. Chem. 292, 11572-11585

81. WARBURG, O. (1956) On respiratory impairment in cancer cells. Science. 124, 269-70

82. Warburg, O. (1956) On the Origin of Cancer Cells. Science. 123, 309-314

83. Engelman, J. a, Chen, L., Tan, X., Crosby, K., Guimaraes, A. R., Upadhyay, R., Maira, M., McNamara, K., Perera, S. a, Song, Y., Chirieac, L. R., Kaur, R., Lightbown, A., Simendinger, J., Li, T., Padera, R. F., García-Echeverría, C., Weissleder, R., Mahmood, U., Cantley, L. C., and Wong, K.-K. (2008) Effective use of PI3K and MEK inhibitors to treat mutant Kras G12D and PIK3CA H1047R murine lung cancers. Nat. Med. 14, 1351-6 
84. Jun, J. C., Rathore, A., Younas, H., Gilkes, D., and Polotsky, V. Y. (2017) Hypoxia-Inducible Factors and Cancer. Curr. Sleep Med. Reports. 10.1007/s40675-017-0062-7

85. Eales, K. L., Hollinshead, K. E. R., and Tennant, D. A. (2016) Hypoxia and metabolic adaptation of cancer cells. Oncogenesis. 5, e190

86. Semenza, G. L., and Wang, G. L. (1992) A nuclear factor induced by hypoxia via de novo protein synthesis binds to the human erythropoietin gene enhancer at a site required for transcriptional activation. Mol. Cell. Biol. 12, 5447-54

87. Semenza, G. L. (2003) Targeting HIF-1 for cancer therapy. Nat. Rev. Cancer. 3, 721-32

88. Liu, W., Shen, S., Zhao, X., and Chen, G. (2012) Targeted genes and interacting proteins of hypoxia inducible factor-1. Int J Biochem Mol Biol. 3, 165-178

89. Semenza, G., Jiang, B. B.-H., Leung, S., Passantino, R., Concordet, J., Maire, P., and Giallongo, A. (1996) Hypoxia Response Elements in the Aldolase A, Enolase 1,and Lactate Dehydrogenase A Gene Promoters Contain Essential Binding Sites for Hypoxia-inducible Factor 1. J. Biol. Chem. 271, 32529-32537

90. Semenza, G. L., Roth, P. H., Fang, H., and Wang, G. L. (1994) Transcriptional Regulation of Genes Encoding Glycolytic. J. Biol. Chem.

91. Ebert, B. L., Firth, J.D., Ratcliffe, P.J. (1995) Hypoxia and Mitochondrial Inhibitors Regulate Expression of Glucose Transporter-1 via Distinct Cis-acting Sequences. J. Biol. Chem. 270, 2908329089

92. Maher, E. R., Neumann, H. P. H., and Richard, S. (2011) von Hippel-Lindau disease: A clinical and scientific review. Eur. J. Hum. Genet. 19, 617-623

93. Iyer, N. V., Kotch, L. E., Agani, F., Leung, S. W., Laughner, E., Wenger, R. H., Gassmann, M., Gearhart, J. D., Lawler, a. M., Yu, a. Y., and Semenza, G. L. (1998) Cellular and developmental control of $\mathrm{O} 2$ homeostasis by hypoxia-inducible factor 1alpha. Genes Dev. 12, 149-162

94. Salceda, S. (1997) Hypoxia-inducible Factor 1alpha (HIF-1alpha) Protein Is Rapidly Degraded by the Ubiquitin-Proteasome System under Normoxic Conditions. ITS STABILIZATION BY HYPOXIA DEPENDS ON REDOX-INDUCED CHANGES. J. Biol. Chem. 272, 22642-22647

95. Taylor, B. L., and Zhulin, I. B. (1999) PAS domains: internal sensors of oxygen, redox potential, and light. Microbiol. Mol. Biol. Rev. 63, 479-506

96. Semenza, G. L. (2013) HIF-1 mediates metabolic responses to intratumoral hypoxia and oncogenic mutations. J. Clin. Invest. 10.1172/JCI67230

97. Bracken, C. P., Whitelaw, M. L., and Peet, D. J. (2003) The hypoxia-inducible factors: key transcriptional regulators of hypoxic responses. Cell. Mol. Life Sci. 60, 1376-93

98. Lando, D., Peet, D. J., Whelan, D. a, Gorman, J. J., and Whitelaw, M. L. (2002) Asparagine hydroxylation of the HIF transactivation domain a hypoxic switch. Science. 295, 858-61

99. Keith, B., Johnson, R. S. R., and Simon, M. C. (2012) HIF1 $\alpha$ and HIF2 $\alpha$ : sibling rivalry in hypoxic tumour growth and progression. Nat. Rev. Cancer. 12, 9-22

100. Ke, Q., and Costa, M. (2006) Hypoxia-Inducible Factor-1 (HIF-1). 70, 1469-1480

101. Makino, Y., Cao, R., Svensson, K., Bertilsson, G., Asman, M., Tanaka, H., Cao, Y., Berkenstam, a, and Poellinger, L. (2001) Inhibitory PAS domain protein is a negative regulator of hypoxiainducible gene expression. Nature. 414, 550-554

102. Li, Q. F., Wang, X. R., Yang, Y. W., and Lin, H. (2006) Hypoxia upregulates hypoxia inducible factor (HIF)-3alpha expression in lung epithelial cells: characterization and comparison with HIF-1alpha. Cell Res. 16, 548-58

103. Maynard, M. a, Evans, A. J., Hosomi, T., Hara, S., Jewett, M. a S., and Ohh, M. (2005) Human HIF3alpha4 is a dominant-negative regulator of HIF-1 and is down-regulated in renal cell carcinoma. FASEB J. 19, 1396-406 
104. Lindebro, M. C., Poellinger, L., and Whitelaw, M. L. (1995) Protein-protein interaction via PAS domains: role of the PAS domain in positive and negative regulation of the bHLH/PAS dioxin receptor-Arnt transcription factor complex. EMBO J. 14, 3528-39

105. Whitelaw, M., Pongratz, I., Wilhelmsson, a, Gustafsson, J. a, and Poellinger, L. (1993) Liganddependent recruitment of the Arnt coregulator determines DNA recognition by the dioxin receptor. Mol. Cell. Biol. 13, 2504-14

106. Yamaguchi, Y., and Kuo, M. T. (1995) Functional analysis of aryl hydrocarbon receptor nuclear translocator interactions with aryl hydrocarbon receptor in the yeast two-hybrid system. Biochem. Pharmacol. 50, 1295-302

107. Tanaka, T., Wiesener, M., Bernhardt, W., Eckardt, K.-U., and Warnecke, C. (2009) The human HIF (hypoxia-inducible factor)-3alpha gene is a HIF-1 target gene and may modulate hypoxic gene induction. Biochem. J. 424, 143-51

108. Pasanen, A., Heikkilä, M., Rautavuoma, K., Hirsilä, M., Kivirikko, K. I., and Myllyharju, J. (2010) Hypoxia-inducible factor (HIF)-3?? is subject to extensive alternative splicing in human tissues and cancer cells and is regulated by HIF-1 but not HIF-2. Int. J. Biochem. Cell Biol. 42, 1189-1200

109. Maynard, M. a, Qi, H., Chung, J., Lee, E. H. L., Kondo, Y., Hara, S., Conaway, R. C., Conaway, J. W., and Ohh, M. (2003) Multiple splice variants of the human HIF-3 alpha locus are targets of the von Hippel-Lindau E3 ubiquitin ligase complex. J. Biol. Chem. 278, 11032-40

110. Ravenna, L., Salvatori, L., and Russo, M. A. (2016) HIF3a: The little we know. FEBS J. 283, 9931003

111. Maynard, M. A., Evans, A. J., Shi, W., Kim, W. Y., Liu, F.-F. F., and Ohh, M. (2007) Dominantnegative HIF-3 alpha 4 suppresses VHL-null renal cell carcinoma progression. Cell Cycle. 6, 28106

112. Zhang, P., Yao, Q., Lu, L., Li, Y., Chen, P.-J. J., and Duan, C. (2014) Hypoxia-Inducible Factor 3 Is an Oxygen-Dependent Transcription Activator and Regulates a Distinct Transcriptional Response to Hypoxia. Cell Rep. 6, 1110-1121

113. Hara, S., Hamada, J., Kobayashi, C., Kondo, Y., and Imura, N. (2001) Expression and characterization of hypoxia-inducible factor (HIF)-3alpha in human kidney: suppression of HIFmediated gene expression by HIF-3alpha. Biochem. Biophys. Res. Commun. 287, 808-13

114. Huang, Y., Kapere Ochieng, J., Kempen, M. B., Munck, A. B., Swagemakers, S., van Ijcken, W., Grosveld, F., Tibboel, D., and Rottier, R. J. (2013) Hypoxia inducible factor $3 \alpha$ plays a critical role in alveolarization and distal epithelial cell differentiation during mouse lung development. PLoS One. 8, e57695

115. Chen, S., Xu, Y., Chen, Y., Li, X., Mou, W., Wang, L., Liu, Y., Reisfeld, R. A., Xiang, R., Lv, D., and Li, N. (2012) SOX2 gene regulates the transcriptional network of oncogenes and affects tumorigenesis of human lung cancer cells. PLoS One. 7, 1-12

116. Xue, X., Jungles, K., Onder, G., Samhoun, J., and Győrffy, B. (2016) HIF-3 $\alpha 1$ promotes colorectal tumor cell growth by activation of JAK-STAT3 signaling. Oncotarget. 10.18632/oncotarget.7272

117. Möglich, A., Ayers, R. a, and Moffat, K. (2009) Structure and signaling mechanism of Per-ARNTSim domains. Structure. 17, 1282-94

118. Henry, J. T., and Crosson, S. (2011) Ligand-binding PAS domains in a genomic, cellular, and structural context. Annu. Rev. Microbiol. 65, 261-86

119. Amezcua, C. A., Harper, S. M., Rutter, J., and Gardner, K. H. (2002) Structure and interactions of PAS kinase N-terminal PAS domain: model for intramolecular kinase regulation. Structure. 10, 1349-61

120. Taylor, B. L., and Zhulin, I. B. (1999) PAS domains: internal sensors of oxygen, redox potential, and light. Microbiol. Mol. Biol. Rev. 63, 479-506

121. Fala, A. M., Oliveira, J. F., Adamoski, D., Aricetti, J. A., Dias, M. M., Dias, M. V. B., Sforça, M. L., Lopes-de-Oliveira, P. S., Rocco, S. A., Caldana, C., Dias, S. M. G., and Ambrosio, A. L. B. (2015) 
Unsaturated fatty acids as high-affinity ligands of the C-terminal Per-ARNT-Sim domain from the Hypoxia-inducible factor 3a. Sci. Rep. 5, 12698

122. Halestrap, A. P. (1975) The mitochondrial pyruvate carrier. Kinetics and specificity for substrates and inhibitors. Biochem. J. 148, 85-96

123. Schell, J., and Rutter, J. (2013) The long and winding road to the mitochondrial pyruvate carrier. Cancer Metab. 1, 6

124. Herzig, S. S., Raemy, E., Montessuit, S., Veuthey, J.-L. J.-L. L., Zamboni, N., Westermann, B., Kunji, E. R. S., and Martinou, J.-C. J.-C. J.-C. C. (2012) Identification and functional expression of the mitochondrial pyruvate carrier. Science (80-. ). 337, 93-96

125. Bricker, D. K., Taylor, E. B., Schell, J. C., Orsak, T., Chen, Y., Cox, J. E., Cardon, C. M., Van, J. G., Dephoure, N., Redin, C., Boudina, S., Gygi, S. P., Thummel, C. S., Rutter, J., Boutron, A., Chen, Y., Cox, J. E., Cardon, C. M., Van Vranken, J. G., Dephoure, N., Redin, C., Boudina, S., Gygi, S. P., Brivet, M., Thummel, C. S., and Rutter, J. (2012) A mitochondrial pyruvate carrier required for pyruvate uptake in yeast, Drosophila, and humans. Science. 337, 96-100

126. Divakaruni, A. S., Wiley, S. E., Rogers, G. W., Andreyev, A. Y., Petrosyan, S., Loviscach, M., Wall, E. a, Yadava, N., Heuck, A. P., Ferrick, D. a, Henry, R. R., McDonald, W. G., Colca, J. R., Simon, M. I., Ciaraldi, T. P., and Murphy, A. N. (2013) Thiazolidinediones are acute, specific inhibitors of the mitochondrial pyruvate carrier. Proc. Natl. Acad. Sci. U. S. A. 110, 5422-7

127. Hunte, C., Koepke, J., Lange, C., Roßmanith, T., and Michel, H. (2000) Structure at $2.3 \AA$ resolution of the cytochrome bc1 complex from the yeast Saccharomyces cerevisiae cocrystallized with an antibody Fv fragment. Structure. 8, 669-684

128. Harrenga, A., and Michel, H. (1999) The Cytochrome c Oxidase from Paracoccus denitrificans Does Not Change the Metal Center Ligation upon Reduction. J. Biol. Chem. 274, 33296-33299

129. Zhou, Y., Morais-Cabral, J. H., Kaufman, A., and MacKinnon, R. (2001) Chemistry of ion coordination and hydration revealed by a K+ channel-Fab complex at 2.0 A resolution. Nature. 414, 43-8

130. Hirsila, M., Koivunen, P., Gunzler, V., Kivirikko, K. I., and Myllyharju, J. (2003) Characterization of the human prolyl 4-hydroxylases that modify the hypoxia-inducible factor. J. Biol. Chem. 278, 30772-30780

131. Biddlestone, J., Bandarra, D., and Rocha, S. (2015) The role of hypoxia in inflammatory disease (Review). Int. J. Mol. Med. 35, 859-869

132. Zhang, Q., Gu, J., Li, L., Liu, J., Luo, B., Cheung, H. W., Boehm, J. S., Ni, M., Geisen, C., Root, D. E., Polyak, K., Brown, M., Richardson, A. L., Hahn, W. C., Kaelin, W. G., and Bommi-Reddy, A. (2009) Control of Cyclin D1 and Breast Tumorigenesis by the EgIN2 Prolyl Hydroxylase. Cancer Cell. 16, 413-424

133. Vogel, S., Wottawa, M., Farhat, K., Zieseniss, A., Schnelle, M., Le-Huu, S., Von Ahlen, M., Malz, C., Camenisch, G., and Katschinski, D. M. (2010) Prolyl Hydroxylase Domain (PHD) 2 affects cell migration and F-actin formation via RhoA/Rho-associated kinase-dependent cofilin phosphorylation. J. Biol. Chem. 285, 33756-33763

134. Lee, D. C., Sohn, H. A., Park, Z. Y., Oh, S., Kang, Y. K., Lee, K. M., Kang, M., Jang, Y. J., Yang, S. J., Hong, Y. K., Noh, H., Kim, J. A., Kim, D. J., Bae, K. H., Kim, D. M., Chung, S. J., Yoo, H. S., Yu, D. Y., Park, K. C., and Yeom, Y. II (2015) A lactate-induced response to hypoxia. Cell. 161, 595-609

135. Katschinski, D. M. (2009) In vivo functions of the prolyl-4-hydroxylase domain oxygen sensors: direct route to the treatment of anaemia and the protection of ischaemic tissues. Acta Physiol. $195,407-414$

136. Takeda, K., Ho, V. C., Takeda, H., Duan, L.-J., Nagy, A., and Fong, G.-H. (2006) Placental but Not Heart Defects Are Associated with Elevated Hypoxia-Inducible Factor Levels in Mice Lacking Prolyl Hydroxylase Domain Protein 2. Mol. Cell. Biol. 26, 8336-8346

137. Place, T. L., and Domann, F. E. (2013) Prolyl-hydroxylase 3: evolving roles for an ancient signaling 
protein. Hypoxia. 2013, 13

138. Vezina, C. M., Lin, T.-M., and Peterson, R. E. (2009) AHR signaling in prostate growth, morphogenesis, and disease. Biochem. Pharmacol. 77, 566-76

139. Köditz, J., Nesper, J., Wottawa, M., Stiehl, D. P., Camenisch, G., Franke, C., Myllyharju, J., Wenger, R. H., and Katschinski, D. M. (2007) Oxygen-dependent ATF-4 stability is mediated by the PHD3 oxygen sensor. Blood. 110, 3610-3617

140. Luo, W., Lin, B., Wang, Y., Zhong, J., O’Meally, R., Cole, R. N., Pandey, A., Levchenko, A., and Semenza, G. L. (2014) PHD3-mediated prolyl hydroxylation of nonmuscle actin impairs polymerization and cell motility. Mol. Biol. Cell. 25, 2788-96

141. Luo, W., Hu, H., Chang, R., Zhong, J., Knabel, M., O’Meally, R., Cole, R. N., Pandey, A., and Semenza, G. L. (2011) Pyruvate kinase M2 is a PHD3-stimulated coactivator for hypoxia-inducible factor 1. Cell. 145, 732-744

142. Garvalov, B. K., Foss, F., Henze, A.-T., Bethani, I., Gräf-Höchst, S., Singh, D., Filatova, A., Dopeso, H., Seidel, S., Damm, M., Acker-Palmer, A., and Acker, T. (2014) PHD3 regulates EGFR internalization and signalling in tumours. Nat. Commun. 5, 5577

143. Koivunen, P., Tiainen, P., Hyvärinen, J., Williams, K. E., Sormunen, R., Klaus, S. J., Kivirikko, K. I., and Myllyharju, J. (2007) An endoplasmic reticulum transmembrane prolyl 4-hydroxylase is induced by hypoxia and acts on hypoxia-inducible factor alpha. J. Biol. Chem. 282, 30544-52

144. Bos, R., van der Groep, P., Greijer, A. E., Shvarts, A., Meijer, S., Pinedo, H. M., Semenza, G. L., van Diest, P. J., and van der Wall, E. (2003) Levels of hypoxia-inducible factor-1alpha independently predict prognosis in patients with lymph node negative breast carcinoma. Cancer. 97, 1573-81

145. Appelhoff, R. J., Tian, Y.-M., Raval, R. R., Turley, H., Harris, A. L., Pugh, C. W., Ratcliffe, P. J., and Gleadle, J. M. (2004) Differential Function of the Prolyl Hydroxylases PHD1, PHD2, and PHD3 in the Regulation of Hypoxia-inducible Factor. J. Biol. Chem. 279, 38458-38465

146. Högel, H., Rantanen, K., Jokilehto, T., Grenman, R., and Jaakkola, P. M. (2011) Prolyl hydroxylase PHD3 enhances the hypoxic survival and G1 to S transition of carcinoma cells. PLoS One. 6, e27112

147. Chowdhury, R., McDonough, M. a, Mecinović, J., Loenarz, C., Flashman, E., Hewitson, K. S., Domene, C., and Schofield, C. J. (2009) Structural basis for binding of hypoxia-inducible factor to the oxygen-sensing prolyl hydroxylases. Structure. 17, 981-9

148. Chowdhury, R., McDonough, M. A., Mecinović, J., Loenarz, C., Flashman, E., Hewitson, K. S., Domene, C., and Schofield, C. J. (2009) Structural Basis for Binding of Hypoxia-Inducible Factor to the Oxygen-Sensing Prolyl Hydroxylases. Structure. 17, 981-989

149. Gorbunova, V., Hine, C., Tian, X., Ablaeva, J., Gudkov, A. V, Nevo, E., and Seluanov, A. (2012) Cancer resistance in the blind mole rat is mediated by concerted necrotic cell death mechanism. Proc. Natl. Acad. Sci. 109, 19392-19396

150. Heron, M. (2012) Deaths: leading causes for 2008. Natl. vital Stat. reports. 60, 1-94

151. Lipman, R., Galecki, A., Burke, D. T., and Miller, R. A. (2004) Genetic loci that influence cause of death in a heterogeneous mouse stock. J. Gerontol. A. Biol. Sci. Med. Sci. 59, 977-83

152. Nevo, E; Ivanitskaya, E. B. A. (2001) Adaptive Radiation of Blind Subterranean Mole Rats. Heredity (Edinb). 89, 325-326

153. Shams, I., Avivi, A., and Nevo, E. (2005) Oxygen and carbon dioxide fluctuations in burrows of subterranean blind mole rats indicate tolerance to hypoxic-hypercapnic stresses. Comp. Biochem. Physiol. - A Mol. Integr. Physiol. 142, 376-382

154. Avivi, A., Gerlach, F., Joel, A., Reuss, S., Burmester, T., Nevo, E., and Hankeln, T. (2010) Neuroglobin, cytoglobin, and myoglobin contribute to hypoxia adaptation of the subterranean mole rat Spalax. Proc. Natl. Acad. Sci. U. S. A. 107, 21570-21575

155. Avivi, a, Ashur-Fabian, O., Joel, a, Trakhtenbrot, L., Adamsky, K., Goldstein, I., Amariglio, N., 
Rechavi, G., and Nevo, E. (2007) P53 in blind subterranean mole rats--loss-of-function versus gain-of-function activities on newly cloned Spalax target genes. Oncogene. 26, 2507-12

156. Scheffler, I. E. (2001) A century of mitochondrial research: Achievements and perspectives. Mitochondrion. 1, 3-31

157. Dudkina, N. V., Kouřil, R., Peters, K., Braun, H. P., and Boekema, E. J. (2010) Structure and function of mitochondrial supercomplexes. Biochim. Biophys. Acta - Bioenerg. 1797, 664-670

158. Kuwana, T., Mackey, M. R., Perkins, G., Ellisman, M. H., Latterich, M., Schneiter, R., Green, D. R., and Newmeyer, D. D. (2002) Bid, Bax, and lipids cooperate to form supramolecular openings in the outer mitochondrial membrane. Cell. 111, 331-342

159. De Pinto, V., Reina, S., Guarino, F., and Messina, A. (2008) Structure of the voltage dependent anion channel: State of the art. J. Bioenerg. Biomembr. 40, 139-147

160. Nelson, D. L., Lehninger, A. L., and Cox, M. M. (2008) Lehninger Principles of Biochemistry (Freeman, W. H. ed)

161. Alberts, B., Johnson, A., Lewis, J., Raff, M., Roberts, K., and Walter, P. (2010) Biologia Molecular da Célula, $5^{a}$ edição, Artmed, Porto Alegre

162. Shoshan-Barmatz, V., and Mizrachi, D. (2012) VDAC1: from structure to cancer therapy. Front. Oncol. 2, 164

163. Yagoda, N., von Rechenberg, M., Zaganjor, E., Bauer, A. J., Yang, W. S., Fridman, D. J., Wolpaw, A. J., Smukste, I., Peltier, J. M., Boniface, J. J., Smith, R., Lessnick, S. L., Sahasrabudhe, S., and Stockwell, B. R. (2007) RAS-RAF-MEK-dependent oxidative cell death involving voltagedependent anion channels. Nature. 447, 865-869

164. Wu, S., Sampson, M. J., Decker, W. K., and Craigen, W. J. (1999) Each mammalian mitochondrial outer membrane porin protein is dispensable: Effects on cellular respiration. Biochim. Biophys. Acta - Mol. Cell Res. 1452, 68-78

165. Anflous-Pharayra, K., Lee, N., Armstrong, D. L., and Craigen, W. J. (2011) VDAC3 has differing mitochondrial functions in two types of striated muscles. Biochim. Biophys. Acta-Bioenerg. $1807,150-156$

166. Sampson, M. J., Decker, W. K., Beaudet, A. L., Ruitenbeek, W., Armstrong, D., Hicks, M. J., and Craigen, W. J. (2001) Immotile Sperm and Infertility in Mice Lacking Mitochondrial Voltagedependent Anion Channel Type 3. J. Biol. Chem. 276, 39206-39212

167. Cheng, E. H. Y., Sheiko, T. V, Fisher, J. K., Craigen, W. J., and Korsmeyer, S. J. (2003) VDAC2 inhibits BAK activation and mitochondrial apoptosis. Science. 301, 513-517

168. Gross, A., Yin, X. M., Wang, K., Wei, M. C., Jockel, J., Milliman, C., Erdjument-Bromage, H., Tempst, P., and Korsmeyer, S. J. (1999) Caspase cleaved BID targets mitochondria and is required for cytochrome $\mathrm{c}$ release, while $\mathrm{BCL}-\mathrm{X}(\mathrm{L})$ prevents this release but not tumor necrosis factor-R1/Fas death. J. Biol. Chem. 274, 1156-1163

169. Horvitz, H. R. (2003) Worms, life, and death (Nobel lecture). in ChemBioChem, pp. 697-711, 4, $697-711$

170. Suzuki, M., Youle, R. J., and Tjandra, N. (2000) Structure of Bax. Cell. 103, 645-654

171. Ma, S., Hockings, C., Anwari, K., Kratina, T., Fennell, S., Lazarou, M., Ryan, M. T., Kluck, R. M., and Dewson, G. (2013) Assembly of the bak apoptotic pore: A critical role for the bak protein $\alpha 6$ helix in the multimerization of homodimers during apoptosis. J. Biol. Chem. 288, 26027-26038

172. Green, D. R., and Evan, G. I. (2002) A matter of life and death. Cancer Cell. 1, 19-30

173. Ghobrial, I. M., Witzig, T. E., and Adjei, A. A. (2005) in BASIC SCIENCE Targeting Apoptosis Pathways in Cancer Therapy. A Cancer J. Clin. 55, 178-194

174. Lazarou, M., Stojanovski, D., Frazier, A. E., Kotevski, A., Dewson, G., Craigen, W. J., Kluck, R. M., Vaux, D. L., and Ryan, M. T. (2010) Inhibition of Bak activation by VDAC2 is dependent on the Bak transmembrane anchor. J. Biol. Chem. 285, 36876-36883 
175. Ross, K., Rudel, T., and Kozjak-Pavlovic, V. (2009) TOM-independent complex formation of Bax and Bak in mammalian mitochondria during TNFalpha-induced apoptosis. Cell Death Differ. 16, 697-707

176. Kozjak-Pavlovic, V., Ross, K., Götz, M., Goosmann, C., and Rudel, T. (2010) A Tag at the Carboxy Terminus Prevents Membrane Integration of VDAC1 in Mammalian Mitochondria. J. Mol. Biol. 397, 219-232

177. Krimmer, T., Rapaport, D., Ryan, M. T., Meisinger, C., Kassenbrock, C. K., Blachly-Dyson, E., Forte, M., Douglas, M. G., Neupert, W., Nargang, F. E., and Pfanner, N. (2001) Biogenesis of porin of the outer mitochondrial membrane involves an import pathway via receptors and the general import pore of the TOM complex. J. Cell Biol. 152, 289-300

178. Ma, S. B., Nguyen, T. N., Tan, I., Ninnis, R., Iyer, S., Stroud, D. a, Menard, M., Kluck, R. M., Ryan, M. T., and Dewson, G. (2014) Bax targets mitochondria by distinct mechanisms before or during apoptotic cell death: a requirement for VDAC2 or Bak for efficient Bax apoptotic function. Cell Death Differ. 21, 1925-1935

179. Schellenberg, B., Wang, P., Keeble, J. A., Rodriguez-Enriquez, R., Walker, S., Owens, T. W., Foster, F., Tanianis-Hughes, J., Brennan, K., Streuli, C. H., and Gilmore, A. P. (2013) Bax Exists in a Dynamic Equilibrium between the Cytosol and Mitochondria to Control Apoptotic Priming. Mol. Cell. 49, 959-971

180. Edlich, F., Banerjee, S., Suzuki, M., Cleland, M. M., Arnoult, D., Wang, C., Neutzner, A., Tjandra, N., and Youle, R. J. (2011) Bcl-xL retrotranslocates Bax from the mitochondria into the cytosol. Cell. 145, 104-116

181. Dewson, G. (2015) Two roads to death - Bax targets mitochondria by distinct routes before or during apoptotic cell death. Mol. Cell. Oncol. 2, e974460

182. Plötz, M., Gillissen, B., Hossini, a M., Daniel, P. T., and Eberle, J. (2012) Disruption of the VDAC2Bak interaction by $\mathrm{Bcl}-\mathrm{xS}$ mediates efficient induction of apoptosis in melanoma cells. Cell Death Differ. 19, 1928-1938

183. Billin, a N., Eilers, a L., Coulter, K. L., Logan, J. S., and Ayer, D. E. (2000) MondoA, a Novel Basic Helix-Loop-Helix-Leucine Zipper Transcriptional Activator That Constitutes a Positive Branch of a Max-Like Network. Mol. Cell. Biol. 20, 8845-8854

184. Davies, M. N., O’Callaghan, B. L., and Towle, H. C. (2008) Glucose Activates ChREBP by Increasing Its Rate of Nuclear Entry and Relieving Repression of Its Transcriptional Activity. J. Biol. Chem. 283, 24029-24038

185. Stoltzman, C. a, Peterson, C. W., Breen, K. T., Muoio, D. M., Billin, A. N., and Ayer, D. E. (2008) Glucose sensing by MondoA:Mlx complexes: a role for hexokinases and direct regulation of thioredoxin-interacting protein expression. Proc. Natl. Acad. Sci. U. S. A. 105, 6912-7

186. Sans, C. L., Satterwhite, D. J., Stoltzman, C. A., Breen, K. T., and Ayer, D. E. (2006) MondoA-Mlx Heterodimers Are Candidate Sensors of Cellular Energy Status: Mitochondrial Localization and Direct Regulation of Glycolysis. Mol. Cell. Biol. 26, 4863-4871

187. Ma, L., Tsatsos, N. G., and Towle, H. C. (2005) Direct role of ChREBP.Mlx in regulating hepatic glucose-responsive genes. J. Biol. Chem. 280, 12019-12027

188. Yamashita, H., Takenoshita, M., Sakurai, M., Bruick, R. K., Henzel, W. J., Shillinglaw, W., Arnot, D., and Uyeda, K. (2001) A glucose-responsive transcription factor that regulates carbohydrate metabolism in the liver. Proc. Natl. Acad. Sci. 98, 9116-9121

189. Burgess, S. C., lizuka, K., Jeoung, N. H., Harris, R. A., Kashiwaya, Y., Veech, R. L., Kitazume, T., and Uyeda, K. (2008) Carbohydrate-response Element-binding Protein Deletion Alters Substrate Utilization Producing an Energy-deficient Liver. J. Biol. Chem. 283, 1670-1678

190. Li, M. V, Chen, W., Poungvarin, N., Imamura, M., and Chan, L. (2008) Glucose-Mediated Transactivation of Carbohydrate Response Element-Binding Protein Requires Cooperative Actions from Mondo Conserved Regions and Essential Trans -Acting Factor 14-3-3. Mol. 
Endocrinol. 22, 1658-1672

191. Tsatsos, N. G., and Towle, H. C. (2006) Glucose activation of ChREBP in hepatocytes occurs via a two-step mechanism. Biochem. Biophys. Res. Commun. 340, 449-456

192. Eilers, A. L., Sundwall, E., Lin, M., Sullivan, A. A., and Ayer, D. E. (2002) A novel heterodimerization domain, CRM1, and 14-3-3 control subcellular localization of the MondoAMlx heterocomplex. Mol Cell Biol. 22, 8514-8526

193. Peterson, C. W., Stoltzman, C. A., Sighinolfi, M. P., Han, K. S., and Ayer, D. E. (2010) Glucose Controls Nuclear Accumulation, Promoter Binding, and Transcriptional Activity of the MondoAMlx Heterodimer. Mol. Cell. Biol. 30, 2887-2895

194. Collier, J. J., Doan, T.-T. T., Daniels, M. C., Schurr, J. R., Kolls, J. K., and Scott, D. K. (2003) c-Myc Is Required for the Glucose-mediated Induction of Metabolic Enzyme Genes. J. Biol. Chem. 278, 6588-6595

195. Havula, E., and Hietakangas, V. (2012) Glucose sensing by ChREBP/MondoA-Mlx transcription factors. Semin. Cell Dev. Biol. 23, 640-647

196. Sloan, E. J., and Ayer, D. E. (2010) Myc, Mondo, and Metabolism. Genes Cancer. 1, 587-596

197. Zhang, P., Metukuri, M. R., Bindom, S. M., Prochownik, E. V, O’Doherty, R. M., and Scott, D. K. (2010) c-Myc Is Required for the ChREBP-Dependent Activation of Glucose-Responsive Genes. Mol. Endocrinol. 24, 1274-1286

198. Li, M. V., Chang, B., Imamura, M., Poungvarin, N., and Chan, L. (2006) Glucose-Dependent Transcriptional Regulation by an Evolutionarily Conserved Glucose-Sensing Module. Diabetes. 55, 1179-1189

199. Davies, M. N., O'Callaghan, B. L., and Towle, H. C. (2010) Activation and repression of glucosestimulated ChREBP requires the concerted action of multiple domains within the MondoA conserved region. Am. J. Physiol. Endocrinol. Metab. 299, E665-E674

200. Billin, A. N., and Ayer, D. E. (2006) The Mlx Network: Evidence for a Parallel Max-Like Transcriptional Network That Regulates Energy Metabolism. in The Myc/Max/Mad Transcription Factor Network, pp. 255-278, Springer-Verlag, Berlin/Heidelberg, 302, 255-278

201. Kawaguchi, T., Takenoshita, M., Kabashima, T., and Uyeda, K. (2001) Glucose and cAMP regulate the L-type pyruvate kinase gene by phosphorylation/dephosphorylation of the carbohydrate response element binding protein. Proc. Natl. Acad. Sci. 98, 13710-13715

202. Merla, G., Howald, C., Antonarakis, S. E., and Reymond, A. (2004) The subcellular localization of the ChoRE-binding protein, encoded by the Williams-Beuren syndrome critical region gene 14, is regulated by 14-3-3. Hum. Mol. Genet. 13, 1505-1514

203. Tsatsos, N. G., Davies, M. N., O'callaghan, B. L., and Towle, H. C. (2008) Identification and function of phosphorylation in the glucose-regulated transcription factor ChREBP. Biochem. J. 411, 261-270

204. Fukasawa, M., Ge, Q., Wynn, R. M., Ishii, S., and Uyeda, K. (2010) Coordinate regulation/localization of the carbohydrate responsive binding protein (ChREBP) by two nuclear export signal sites: Discovery of a new leucine-rich nuclear export signal site. Biochem. Biophys. Res. Commun. 391, 1166-1169

205. Sakiyama, H., Wynn, R. M., Lee, W.-R., Fukasawa, M., Mizuguchi, H., Gardner, K. H., Repa, J. J., and Uyeda, K. (2008) Regulation of Nuclear Import/Export of Carbohydrate Response Elementbinding Protein (ChREBP). J. Biol. Chem. 283, 24899-24908

206. Li, M. V., Chen, W., Harmancey, R. N., Nuotio-Antar, A. M., Imamura, M., Saha, P., Taegtmeyer, H., and Chan, L. (2010) Glucose-6-phosphate mediates activation of the carbohydrate responsive binding protein (ChREBP). Biochem. Biophys. Res. Commun. 395, 395-400 


\title{
Mitochondrial localization and structure-based phosphate activation mechanism of Glutaminase C with implications for cancer metabolism
}

\author{
Alexandre Cassago ${ }^{a}$, Amanda P. S. Ferreira ${ }^{a}$, Igor M. Ferreiraa, Camila Fornezaria, Emerson R. M. Gomes ${ }^{a}$, \\ Kai Su Greene ${ }^{b}$, Humberto M. Pereirac, Richard C. Garrattc, Sandra M. G. Dias ${ }^{\mathrm{a}, 1,2}$, and Andre L. B. Ambrosio ${ }^{\mathrm{a}, 1,2}$ \\ aLaboratório Nacional de Biociências, Centro Nacional de Pesquisa em Energia e Materiais, Campinas-SP 13083-970, Campinas, Brazil; ${ }^{b}$ Department of
Molecular Medicine, College of Veterinary Medicine, Cornell University, Ithaca, NY 14853-6401; and 'Centro de Biotecnologia Molecular Estrutural, \\ Instituto de Física de São Carlos, Universidade de São Paulo, São Carlos-SP 13560-970, São Carlos, Brazil
}

Edited by Gregory A. Petsko, Brandeis University, Waltham, MA, and approved November 18, 2011 (received for review August 2, 2011 )

\begin{abstract}
Glutamine is an essential nutrient for cancer cell proliferation, especially in the context of citric acid cycle anaplerosis. In this manuscript we present results that collectively demonstrate that, of the three major mammalian glutaminases identified to date, the lesser studied splice variant of the gene $g / s$, known as Glutaminase C (GAC), is important for tumor metabolism. We show that, although levels of both the kidney-type isoforms are elevated in tumor vs. normal tissues, GAC is distinctly mitochondrial. GAC is also most responsive to the activator inorganic phosphate, the content of which is supposedly higher in mitochondria subject to hypoxia. Analysis of X-ray crystal structures of GAC in different bound states suggests a mechanism that introduces the tetramerization-induced lifting of a "gating loop" as essential for the phosphate-dependent activation process. Surprisingly, phosphate binds inside the catalytic pocket rather than at the oligomerization interface. Phosphate also mediates substrate entry by competing with glutamate. A greater tendency to oligomerize differentiates GAC from its alternatively spliced isoform and the cycling of phosphate in and out of the active site distinguishes it from the liver-type isozyme, which is known to be less dependent on this ion.
\end{abstract}

glutamine metabolism | Warburg effect

$\mathbf{T}$ he highly proliferative phenotype places special demands upon the metabolism of transformed cells. An upscaled glycolytic pathway, even in the presence of oxygen, is used by tumors to supply a great deal of its energetic and biosynthetic demand for cell division. Aerobic glycolysis, or the Warburg effect, as this phenomenon is commonly known, is accepted today as a metabolic hallmark of cancer cells and has been exploited for diagnosis $(1,2)$. In addition to glucose, tumors are also required to take up great amounts of other extracellular nutrients, such as the amino acid glutamine, and quickly and efficiently metabolize them for shunting into the appropriate pathways $(3,4)$.

Glutamate production by mitochondrial glutaminase (GA), the first enzyme in glutaminolysis, is a key process for body homeostasis, and a crucial carbon donor for amino acid and lipid synthesis in tumor cells, as reviewed by DeBerardinis, et al. (4). To date, three mammalian GAs have been identified: the Liver-type [LGA or GLS2 (5)], the Kidney-type [KGA (6)] and Glutaminase $\mathrm{C}$ [GAC, (7)] a splice variant of KGA (both usually referred to as GLS1). Overall, LGA and KGA present distinct tissue distributions and phosphate dependence for catalysis $(8,9)$. Recent studies have also stressed the importance of glutaminolysis in maintaining the malignant phenotype, providing indications that glutaminases may be potential therapeutic targets in some cancer cells $(4,10-13)$. Elevated GAC mRNA levels have been detected in glyomas $(14,15)$, colorectal carcinomas and adenomas (16), and breast tumor cell lines (7), when compared to normal cells. Gao and coworkers showed that c-Myc induces elevated GAC expression in both prostate cancer and B lymphoma cell lines as well as in prostate cancer tissues vs. normal (17). Importantly,
Wang and colleagues have shown that modulation of the aberrant GA activity via a small molecule, for which GAC was the identified target, inhibits oncogenic transformation (18). This collection of literature raises the suggestion that GAC is the key glutaminase isozyme in tumors. Thus, understanding the molecular basis of GAC's activity and, most importantly, distinguishing it from the KGA and LGA isozymes, will contribute to our understanding of tumor metabolism.

Here we demonstrate that both GAC and KGA protein levels are increased in breast tumors compared to normal healthy tissues. Furthermore a similar pattern is repeated in cases of higher compared to lower grades of invasive ductal breast carcinoma. Cell fractionation of breast, prostate, and lung tumor cell lines, followed by immunoblotting using isoform-specific antibodies indicated that, under the experimental conditions used, GAC but not KGA was found in the mitochondria. Subsequently we show that GAC is the most efficient of the three isozymes in hydrolyzing glutamine in the presence of inorganic phosphate (Pi). Crystal structures of GAC in different states (ligand-free and either bound to phosphate or L-glutamate) established a "gating loop" as the tetramer-driven mechanism of protein activation and show how phosphate enhances catalysis. Our data collectively suggest that GAC is key to the mitochondrial glutaminase metabolism of cancer cells because of its exclusive localization and kinetic properties.

\section{Results}

Protein Levels and Localization of the Kidney-Type Isoforms. KGAand GAC-specific antibodies (Fig. S1 $A-C$ ) were employed in immunohystochemical analyses of two human breast cancer tissue arrays. The results show that the expression levels of both isoforms are increased in tumors compared to normal tissues and positively correlate to the tumor grade (Fig. 1A, Fig. S1D). Moreover, the data show that in breast (SKBR3 and MDA-MB231), prostate (PC3 and DU145) and lung (A549) tumor cell lines, KGA is localized in the cytosol but not in the mitochondria

Author contributions: S.M.G.D. and A.L.B.A. designed research; A.C., A.P.S.F., I.M.F., C.F., E.R.M.G. K.S.G. S.M.G.D and A.L.B.A performed research; A.C. H.M.P., R.C.G., S.M.G.D., and A.L.B.A. analyzed data; and S.M.G.D. and A.L.B.A. wrote the paper.

The authors declare no conflict of interest.

This article is a PNAS Direct Submission.

Data deposition: The atomic coordinates and structure factors have been deposited in the Protein Data Bank www.pdb.org [PDB ID codes 3ss3 (ligand-free GAC), 3ss4 (phosphatebound GAC), and 3ss5 (L-glutamate-bound GAC)].

${ }^{1}$ S.M.G.D. and A.L.B.A. contributed equally to this work.

${ }^{2}$ To whom correspondence may be addressed at: Laboratório Nacional de BiociênciasLNBio, Centro Nacional de Pesquisa em Energia e Materiais-CNPEM, Rua Giuseppe Máximo Scolfaro, 10.000, Pólo II de Alta Tecnologia, Campinas, SP, 13083-100, Brazil. E-mail: andre.ambrosio@Inbio.org.br or sandra.dias@Inbio.org.br.

This article contains supporting information online at www.pnas.org/lookup/suppl/ doi:10.1073/pnas.1112495109/-/DCSupplemental. 
A
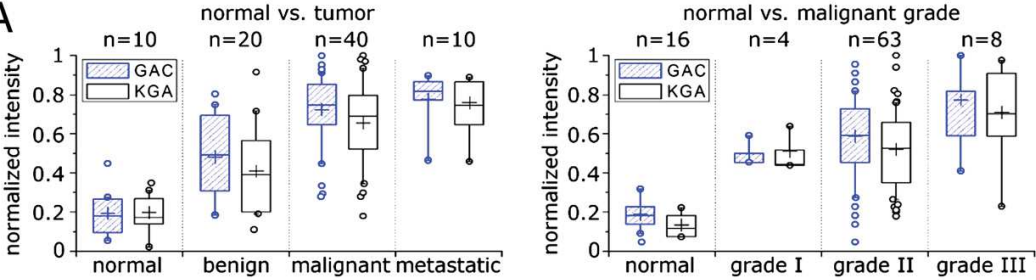

B

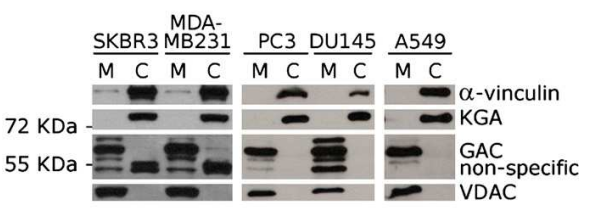

C

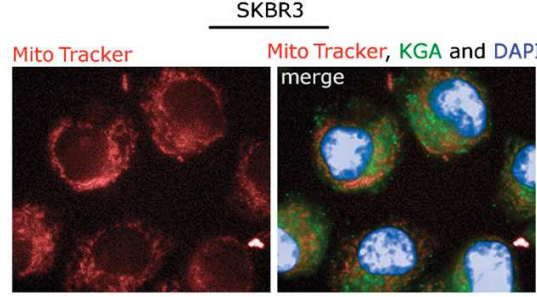

Fig. 1. KGA and $G A C$ are enhanced in cancer, but only GAC is found in mitochondria. $(A)$ Box-and-whisker representation of the immunohystochemical analysis of human breast cancer tissue arrays. Isozymespecific antibodies show that protein levels of both GAC and KGA increase in tumor tissues when compared to their normal healthy counterparts, and correlate both with the degree of malignancy (left box) and the grade of the tumor (right box). Intensities were normalized to the highest count measured. Lower and upper quartiles represent $25 \%$ and $75 \%$ of the data points and the middle band is the median. Whisker's lengths define data between $10 \%$ and $90 \%$. Outliers are shown as circles. Crosses indicate mean value of each set of data. (B) Fractioning of the breast SKBR3 and MDA-MB231, prostate PC3 and DU145 and lung A549 tumor cell lines followed by immunoblotting shows that KGA is found in the cytosol but not in the mitochondria, as opposed to GAC. (C) KGA cytoplasmic location was confirmed by immunofluorescence of SKBR3 cells stained with both MitoTracker and DAPI.
(Fig. $1 B$ ), as confirmed by immunofluorescence of SKBR3 cells (Fig. 1C). In contrast, GAC is the only isoform present in the mitochondria (Fig. 1B). LGA mRNA levels were very low in the breast tumor cell lines in comparison with HMEC (Fig. S1E), as has been reported for the prostate cancer cell line PC3 and the lymphoma cell line B P493 (17). This observation might be related to p53 inactivation $(19,20)$.

Enzyme Characterization. Intrigued by the above mentioned findings, we decided to study the catalytic properties of GAC in comparison to the other two isozymes. Equal concentrations of protein $(5 \mathrm{nM})$ were tested for their ability to catalyze the hydrolysis of $\mathrm{L}$-glutamine in the presence of phosphate $(\mathrm{Pi}, 0$ to $50 \mathrm{mM}$ final concentration). We verified that the addition of phosphate leads to an increase in the turnover rate of all glutaminases, but at distinct levels. KGA $k_{\text {cat-app }}$ increases from $7.2 \mathrm{~s}^{-1}$ in the absence of Pi to $29.7 \mathrm{~s}^{-1}$ at $50 \mathrm{mM}$ Pi. Within the same range of phosphate, the $k_{\text {cat-app }}$ of GAC and LGA present a similar marked increase, going from $7.8 \mathrm{~s}^{-1}$ and $6.9 \mathrm{~s}^{-1}$ to $37.0 \mathrm{~s}^{-1}$ and $43.1 \mathrm{~s}^{-1}$, respectively. Simultaneously, the $K_{m \text {-app }}$ for KGA and GAC decreased as $\mathrm{Pi}$ concentration increased, going from $15.6 \mathrm{mM}$ and $18.4 \mathrm{mM}$ (in the absence of $\mathrm{Pi}$ ) to 8.5 and $2.1 \mathrm{mM}$ (at $50 \mathrm{mM} \mathrm{Pi}$ ), respectively. In sharp contrast the $K_{m \text {-app }}$ of LGA increased four times over the same interval of Pi concentration starting at $15.2 \mathrm{mM}$ and going up to $60.5 \mathrm{mM}$, at $50 \mathrm{mM}$ $\mathrm{Pi}$. The parameters reported above, as well as those obtained at intermediate $\mathrm{Pi}$ concentrations are shown in Fig. $2 A$ and $B$. Validation of the coupled assay, original activity data with standard deviations, as well as kinetic curves are presented in Tables $\mathrm{S} 1$ and S2, Fig. S2 $A-D$.

The overall individual behaviors become more evident when we plot the catalytic efficiency $\left(k_{\text {cat-app }} / K_{m \text {-app }}\right)$ as a function of the concentration of Pi (Fig. 2C). For LGA, the increase in $k_{\text {cat-app }}$ coupled to that of $K_{m \text {-app }}$, resulted in little to no change in its efficiency over the range of Pi concentration studied $\left(0.5 \mathrm{mM}^{-1} \cdot \mathrm{s}^{-1}\right.$ in the absence of $\mathrm{Pi}$ and $0.7 \mathrm{mM}^{-1} \cdot \mathrm{s}^{-1}$ at $50 \mathrm{mM} \mathrm{Pi}$ ), in agreement with previous knowledge of its low affinity for glutamine and low phosphate dependence (8). In the absence or at low phosphate levels, KGA is as effective as LGA, but presents an eightfold gain in efficiency at $50 \mathrm{mM}$ Pi. Strikingly, GAC becomes by far the most effective isozyme in converting glutamine to glutamate as the concentration of $\mathrm{Pi}$ is increased (Fig. 2C), since an improvement of over 40 times in its catalytic efficiency is observed within the range from $0 \mathrm{mM}$ to $50 \mathrm{mM} \mathrm{Pi}\left(k_{\text {cat-app }} / K_{m \text {-app }}\right.$ of $0.4 \mathrm{mM}^{-1} \cdot \mathrm{s}^{-1}$ and $17.6 \mathrm{mM}^{-1} \cdot \mathrm{s}^{-1}$, respectively).

Structure of Ligand-Free GAC. To provide further insight into its functional details, we solved the GAC structure in three different states. A ligand-free form was solved by molecular replacement using the active site portion of the human glutaminase (PDB entry 3czd) as search model, and refined to $2.42 \AA$ resolution ( $R_{\text {factor }}$ of $19.5 \%$ and $R_{\text {free }}$ of $25.0 \%$ ) (Table S3). The assymetric unit is composed by four GAC molecules, with the monomers spanning the residues Lys144 to Arg550 (NCBI reference sequence NP_001106854.1). The crystallized construct consisted of residues Met128 to Ser603, thus missing 15 residues at the $\mathrm{N}$ terminus and 53 at the $\mathrm{C}$ terminus (Fig. $3 A$ ). Loop regions between residues Ala153 and Gly155, Asp253 and Gln257, Leu191 and Val198, Gly320 and Ile326 were consistently poorly ordered across the monomers and therefore not modeled into the electron density. Structural details are presented using chain A as reference.

No function has been described so far for the N-terminal region of mammalian glutaminases, which in mouse GAC comprises residues Pro76 to Val225. In our crystal structure, we have found that residues Leu144 to Asn221 fold into a unicornate four-helix bundle. Among the helices, the amphipathic LXXLL motif (commonly termed the NR box, short for Nuclear Receptor box, where $\mathrm{X}$ is any amino acid) can be recognized spanning residues Leu144 to Leu148. NR boxes participate in protein-protein interactions associated with different aspects of transcriptional regulation of nuclear receptor coregulators (21). The hypothesis that glutaminases may participate in transcription regulation has been raised previously (22), however there is still a lack of experimental evidence. A more detailed analysis of this region can be found in Fig. S3 $A-D$.
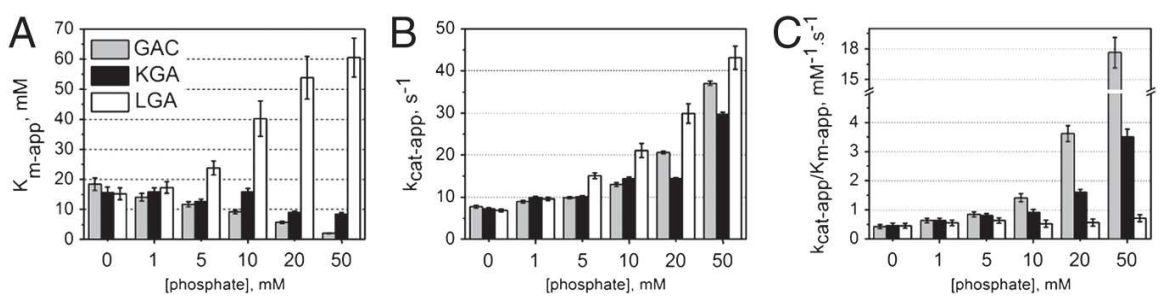

Fig. 2. GAC has the highest activity in the presence of phosphate. (A) Kinetic analysis of the three isozymes shows that the apparent affinity for glutamine of KGA and GAC increases with higher concentrations of $\mathrm{Pi}$, as opposed to what is observed for LGA, as suggested by their $K_{m \text {-app }}$ values. (B) Catalytic rates are increased, though at lower levels for $\mathrm{KGA}$, as more phosphate is added to the reaction. (C) GAC becomes the most efficient isozyme already at concentrations of $\mathrm{Pi}$ around $10 \mathrm{mM}$. 
A

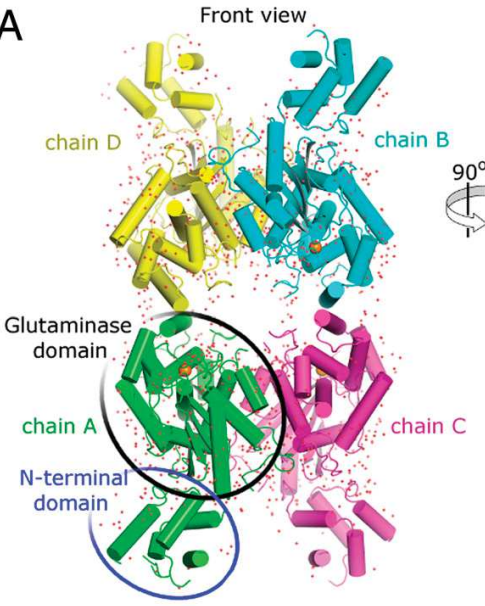

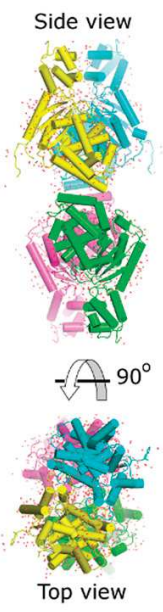

B
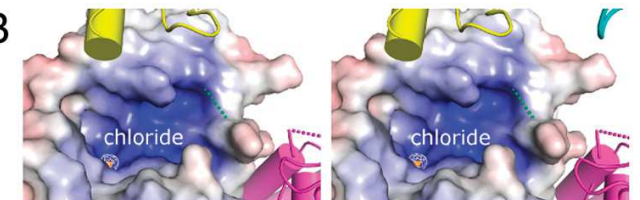

C

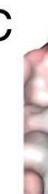

D

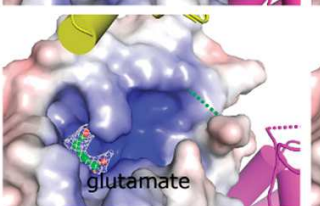

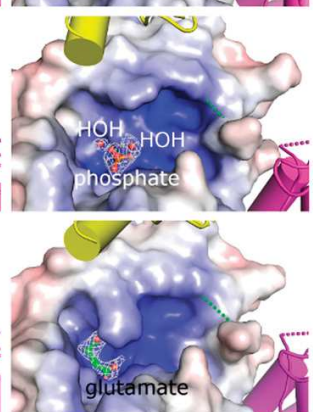

Fig. 3. The crystal structure of GAC. (A) Orthogonal views of the tetramer in cartoon representation. Circles indicate, in chain A, the two distinct domains comprising the full structure: amino-terminal and glutaminase. Though present in the crystallized construct, the $\mathrm{C}$ terminus is heterogeneous in conformation and could not be successfully modeled. Stereographic views of the cationic active site of GAC, represented by electrostatic surface mapping $\left( \pm 8 k_{b} T e_{c}{ }^{-11}\right)$ for the three crystal forms, show the presence of chloride $(B)$, phosphate $(C)$ and Lglutamate $(D) .2 F_{o}-F_{c}$ Fourier electron density maps of the ligands are contoured at $1 \sigma$.
The glutaminase domain in GAC is comprised of residues Lys 249 to Tyr535, and belongs to the beta-lactamase/transpeptidaselike superfamily, as previously described $(*, 23)$. The active site is located between two tightly associated subdomains: an $\alpha / \beta / \alpha$ sandwich subdomain, including a $\beta$-sheet composed of $5 \beta$-strands and a purely $\alpha$-helical subdomain, arranged into a bifurcated fold. According to the $3 \mathrm{~V}$ (Voss Volume Voxelator) server (24), the catalytic pocket has a volume of $580 \AA^{3}$. Electrostatic potential surface mapping shows a very positively charged active site (Fig. $3 B$ ), receiving contributions from Lys294 and Lys486 as well as the N-terminal dipole moment of helices spanning residues Ser291 to Leu305 and Asn340 to Ile350. One chloride ion was found inside the active site of each monomer, interacting with the catalytic residue Ser291, as well as Tyr471 and Val489. This very favorable coordination [gain in free energy of $-10.6 \mathrm{kcal} / \mathrm{mol}$ upon complex formation, according to the PISA (Protein Interfaces, Surfaces and Assemblies) server (25)] explains previous biochemical reports that glutaminase activity is actually impaired under high concentrations of sodium chloride (9), which adds up to $700 \mathrm{mM}$ in the crystallization condition. The majority of the C-terminal portion of GAC is conformationally heterogeneous and therefore could not be modeled. No potential function has been suggested to date for the GAC carboxy-terminal region.

The assembly of the four monomers in the asymmetric unit correlates well in size and shape with the oligomer obtained in solution after size-exclusion purification, either in the absence or presence of $40 \mathrm{mM}$ phosphate, as confirmed by small angle $\mathrm{X}$-ray scattering (SAXS) (Fig. S4A). In our structure, chains A and $\mathrm{C}$ form one of the dimers and chains $\mathrm{B}$ and $\mathrm{D}$ the complementary one. The contacts that define the dimers and the tetramers are all within the glutaminase domain. According to the default criteria of the PISA server, 45 residues from each monomer share the dimer interface, making 20 hydrogen bonds (nine salt bridges), resulting in a gain in solvation energy of $-11.3 \mathrm{kcal} /$ mol and about $1,600 \AA^{2}$ of occluded area. The tetramer is then formed by the pairing of chain A with chain D and chain B with chain $\mathrm{C}$. The dimers are twisted by about $25^{\circ}$ with respect to each other, along the shortest axis of the oligomer (Fig. S4B). The interfaces result from the stacking of equivalent $\alpha$-helices extending from Asp391 to Lys401 and are mediated mostly by hydrophobic interactions between Phe394, Ala395, Tyr398, and Tyr399. Each pairing buries on average $460 \AA^{2}$ of area and also favors the formation of four hydrogen bonds (three salt bridges), with an average gain in solvation energy of $-7.5 \mathrm{kcal} / \mathrm{mol}$. Oppositely charged residues (Asp391 and Lys401) sit on opposing ends of the

*Karlberg T, (2008) Manuscript still to be published. Coordinate file and structure factors available at http://www.thesgc.org/structures/details?pdbid=3CZD also www.rcsb.org, under code 3czd. helix, therefore providing proper orientation of the complementary interfaces.

Structures of Phosphate- and L-Glutamate-Bound GAC. To gain insight into the molecular mechanism that drives the activation of GAC, we have also determined its crystal structure bound to Pi at $2.85 \AA$ resolution ( $R_{\text {factor }}$ and $R_{\text {free }}$ of $22.7 \%$ and $26.9 \%$, respectivelyTable S3). This crystal is isomorphous with the ligand-free form, containing the same tetramer in the asymmetric unit (backbone rmsd of $0.43 \AA$ ). Our current knowledge regarding the activation mechanism of GA is related to the correlation between the presence of phosphate and the protein's quaternary structure, in which dimers associate into tetramers, thus establishing the catalysis-competent state of the enzyme $(26,27)$. This model led us to expect phosphate ions interacting in the surroundings of the tetramerization interface. Surprisingly only one ion was found per monomer, and this was buried inside the highly positive active site where it makes polar contacts with Ser291, Asn340 and Tyr471, and two water molecules (Fig. 3C). On average, the presence of $\mathrm{Pi}$ inside the active site results in a gain in free energy of $-5.4 \mathrm{kcal} / \mathrm{mol}$. Furthermore, as a consequence of the binding of Pi to Ser291 and Tyr471, the chloride ion found in the previous structure is displaced from the active site.

We subsequently grew crystals of GAC previously incubated with $10 \mathrm{mM}$ sodium L-glutamate. The final model was refined to $2.80 \AA$ A resolution $\left(R_{\text {factor }}\right.$ and $R_{\text {free }}$ of $20.6 \%$ and $24.0 \%$, respectively). The overall structure is highly conserved, with a core rmsd of $0.31 \AA$ and $0.40 \AA$, when superposed to the ligand-free and the phosphate-bound models, respectively. One molecule of L-glutamate is found bound to the active site of each monomer (Fig. $3 D$ ). The amino group in the main chain branch of the ligand is hydrogen-bonded to Glu386, Asn340, Tyr419, and Asn393. On its side chain branch, the carboxylic acid moiety makes polar interactions with Ser291, Tyr471 and the main chain nitrogen of Val489.

Structure-Based Biochemistry. To determine key events for GAC activation, we generated a point mutant by replacing Phe394 from the tetramer interface by a serine (Fig. $4 A$ ), termed GAC.F394S. This mutation was enough to break the tetramer into dimers, even in the presence of high phosphate concentrations (Fig. S5A). Differently from the wild-type GAC, the addition of phosphate to GAC.F394S had little effect on its $K_{m \text {-app }}(14.0 \mathrm{mM}$ and $12.3 \mathrm{mM}$ for $0 \mathrm{mM}$ and $50 \mathrm{mM} \mathrm{Pi}$, respectively), and changed little its already low catalytic efficiency $\left(k_{\text {cat-app }} / K_{m \text {-app }}\right.$ of $0.4 \mathrm{mM}^{-1} \cdot \mathrm{s}^{-1}$ and $1.0 \mathrm{mM}^{-1} \cdot \mathrm{s}^{-1}$ ) when in the absence and presence of $50 \mathrm{mM} \mathrm{Pi}$, respectively (Fig. 4B, Fig. S2, Table S1), reinforcing the importance of tetramerization for protein activation.

As already mentioned, GAC eluted as a tetramer after sizeexclusion purification (Fig. S4A). By making serial dilutions of pure protein samples and running them in a gel-filtration column, 
we were able to show that tetramerization is a concentrationdependent event. In Fig. 4C (left box), we observe successive shifts in the population equilibrium, starting at the Stokes radius expected for the tetramer and moving towards smaller species, closer to the radius of the dimer, as the solution is diluted [Stokes radii calculated by Hydropro (28), based on the crystal structure]. Due to experimental sensitivity limitations, the lowest protein concentration measured was $50 \mathrm{nM}$. We then performed the glutaminase assay in the absence of $\mathrm{Pi}$, at GAC concentrations similarly to those used in the serial dilution experiment (ranging from $25 \mathrm{nM}$ to $200 \mathrm{nM}$ ). Interestingly, the results (Fig. 4C, right box, Fig. S2E) readily show a much lower $K_{m}$ at $25 \mathrm{nM}$ GAC $(4.3 \mathrm{mM})$, when compared to $5 \mathrm{nM}$ GAC $\left(K_{m}\right.$ of $18.4 \mathrm{mM}$, Table S1). As GAC concentration was increased further up to $200 \mathrm{nM}$, the $K_{m}$ dropped to $0.9 \mathrm{mM}$ which correlates well with the presence of the heavier species (Fig. $4 C$, left box). Nonetheless, the turnover rates remained low at all protein concentrations tested, resulting in little change in enzyme efficiency $\left(k_{\text {cat }} / K_{m}\right.$ going from $0.5 \mathrm{mM}^{-1} \cdot \mathrm{s}^{-1}$ to $1.1 \mathrm{mM}^{-1} \cdot \mathrm{s}^{-1}$ at $25 \mathrm{nM}$ and $200 \mathrm{nM}$ GAC, respectively), confirming that increases in the turnover rates of GAC depend specifically on Pi and are not solely determined by tetramerization (Fig. 2). This observation can be explained by the crystal structures presented here, which show that phosphate and glutamate compete for the same residues of the cationic active site. Fig. $3 C$ and $D$ show that both anions contact Ser291, the nucleophilic agent of catalysis, and $\mathrm{Pi}$ is therefore likely to promote product release during the catalytic cycle and to reduce product accumulation-induced inhibition of GLS1 $(29,30)$. We then conclude that while protein tetramerization is important for increasing substrate affinity, phosphate guarantees the cycling of the enzyme.

We next focused our attention on the dimer-dimer intermolecular contacts looking for clues for the molecular basis of the oligomerization-driven GAC activation. Particularly noteworthy is the side chain of Phe327, which in all monomers, is part of a hydrophobic cluster located at the tetramer interface, formed by the complementary stacking of Phe327 itself, Ala395, Ile396, Tyr399, in chain A, with its equivalent residues in chain D. Phe327 is the first well structured residue after a consistently disordered six-residue-long loop found across the three structures (Leu321 to Leu326, Fig. 4D). This observation, combined with its close proximity to the active site region, led us to hypothesize about a possible role in regulating accessibility to the active site, explaining why tetramerization decreases the $K_{m}$ of the enzyme. The underlying rationale is that, in the GAC dimer, the open form of this loop (hereon referred to as the gating loop), is transient and a closed form must be present in large excess, leading to a low affinity and a limited hydrolytic rate for glutamine. Accompanying tetramer assembly, conformational changes involving Phe327 are triggered, lifting the gating loop and exposing the active site. If this assumption is correct, then artificially disturbing the loop would result in a more substrate accessible glutaminase. Indeed, the point mutant Phe327Ser (GAC.F327S) showed a $K_{m}$ as low as $8.2 \mathrm{mM}$, even in the absence of phosphate and at only $5 \mathrm{nM}$ protein concentration (Fig. $4 C$ ). The $K_{m}$ then dropped to $0.8 \mathrm{mM}$ when $50 \mathrm{mM}$ of $\mathrm{K}_{2} \mathrm{HPO}_{4}$ was added to the assay, thus showing the importance of the gating loop in regulating active site accessibility.

Finally, serial dilution experiments with wild-type GAC, followed by gel-filtration in the presence of $20 \mathrm{mM} \mathrm{K} \mathrm{HPO}_{4}$, showed a shift in the equilibrium of the species towards tetramers and higher oligomers, when compared to the protein in the absence of Pi (Fig. 4C), as already reported (29, 30). Apart from its effect in enzyme cycling, another direct effect of the addition of $\mathrm{Pi}$ is the stabilization of tetramers, likely by inducing the opening of the gating loop. Indeed, chloride, which competes with Pi for binding to the catalytic Ser291, at high concentration $(500 \mathrm{mM}$ $\mathrm{NaCl}$ ) can dislodge phosphate from its site and shift the protein equilibrium to lower-order oligomers (Fig. S5B).

GAC and KGA: Same Active Site, Different Catalytic Capabilities. The splicing event that originates GAC occurs at the C-terminalencoding region of the $g l s$ gene. Therefore, the N-terminal and glutaminase domains of both KGA and GAC are identical, indicating that the carboxy-terminal region must be crucial for the observed differences in enzymatic behavior (Fig. 2). The great majority of the C-terminal portion of GAC is conformationally heterogeneous in our crystal structures and therefore could not be
A
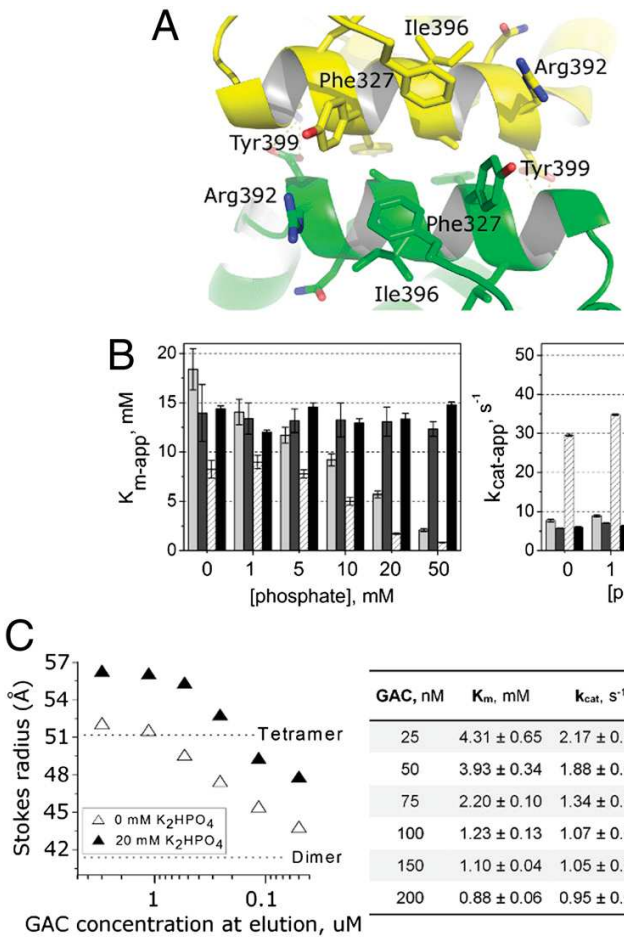
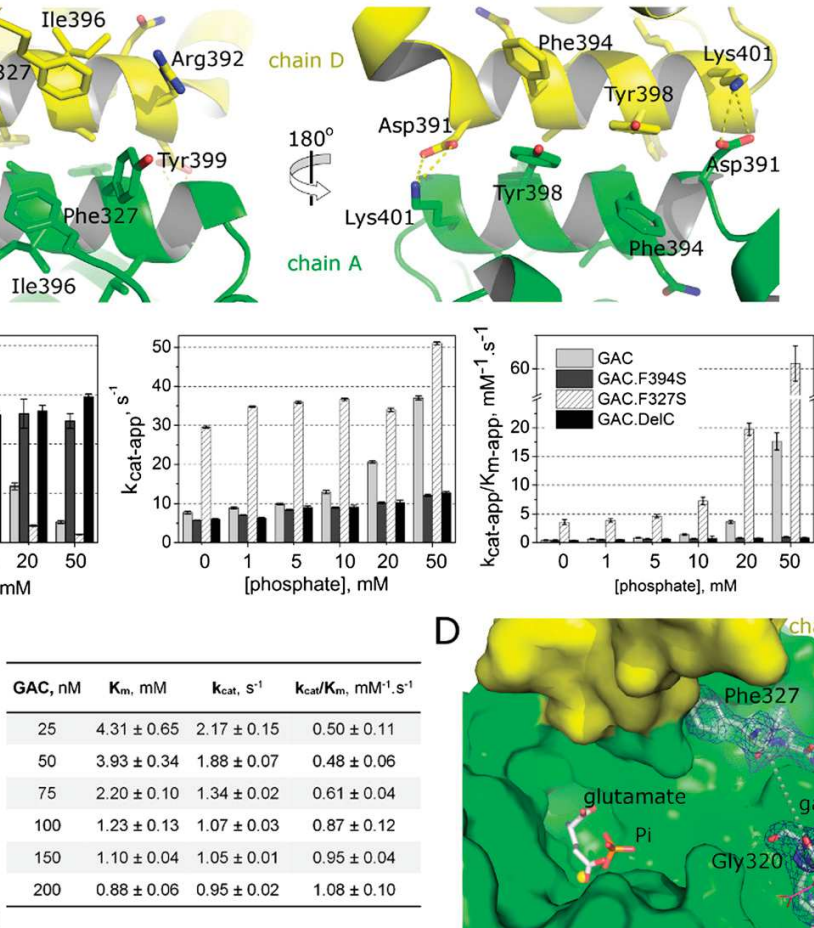

$\mathrm{D}$

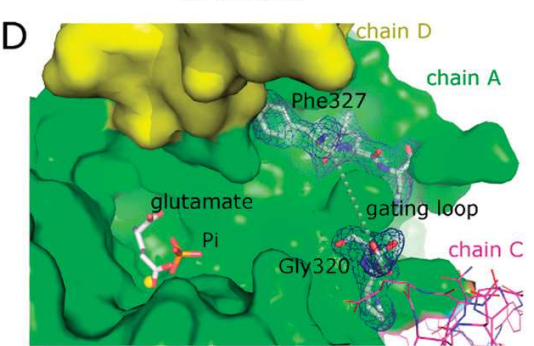

Fig. 4. Activation mechanism based on the gating loop and inorganic phosphate. (A) Perpendicular views of the tetramer interface, defined by the symmetric stacking of the helix between residues Asp391 and Lys401 from each monomer. (B) Enzymatic characterization of point and deletion mutants in comparison to the wild-type enzyme show loss-of-function for GAC.F394S and GAC.DelC and gain-of-function for GAC.F327S. (C) Decrease in the $K_{m}$ for glutamine of GAC (right box) correlates with its protein concentration-dependent oligomerization profile, as determined by size-exclusion chromatography. Introduction of phosphate to the protein solution results in shifts of the equilibrium towards higher molecular weight species. $(D)$ Top view of the active site of GAC and its proximity to the gating loop (dashed line between Gly320 and Phe327). Phe327 is part of the buried interface upon tetramer formation. Fourier $2 F_{o}-F_{c}$ electron density map (contoured at $1 \sigma$ ) shows that residues flanking the loop are well ordered. Relative positions of $\mathrm{Pi}$, L-glutamate and the chloride ion can be seen inside the active site, as a result of structure superposition. 
modeled. Secondary structure prediction using internet tools suggests this region to contain a short $\alpha$-helix (from Tyr563 to Leu572) and an extended strand spanning residues Thr590 to Glu597, interspersed within random coil. KGA on the other hand, is predicted to have three ankyrin repeats within its longer $\mathrm{C}$-terminal region (Fig. S6).

KGA serial dilution, both in the presence and absence of phosphate (Fig. 5), shows a much slower drift in the equilibrium toward larger species when compared to GAC (Fig. 4C), which is reflected in the kinetic parameters obtained by increasing the KGA concentration (original curves in Fig. S2E). In going from $5 \mathrm{nM}$ to $200 \mathrm{nM} \mathrm{KGA}$, its $K_{m}$ is reduced only by about 2.5 times, as opposed to 14 times in the case of GAC`s (Fig. $4 C$ ). Deletion of the stretch between residues Arg539 to Ser 603 of GAC (GAC.DelC), which represents a common denominator between KGA and GAC, especially increased the $K_{m \text {-app }}$ of the protein, even in the presence of phosphate, to levels of the dimer mutant (Fig. $4 B$ ), suggesting that the unique $\mathrm{C}$ terminus of GAC is important for facilitating protein oligomerization, though the specifics are still not clear.

\section{Discussion}

GAC Was Found in the Mitochondria and KGA in the Cytoplasm: Implications for Cancer Metabolism. The central role played by glutamine-based intermediary metabolism in malignant cells has been recently highlighted with the observation that previously known oncogenes and signaling pathways tightly regulate glutaminase expression and activity levels. Gao and coworkers have shown that c-Myc induces elevated GA expression in prostate cancer and B lymphoma cell lines (17). Curiously, the GLS1 isoform induced by Myc in mitochondria of P493-6 B cells was GAC. Wang and coworkers demonstrated that transformed fibroblasts and breast cancer cells exhibit elevated GA activity that is dependent on Rho GTPases and NF- $\kappa$ B activity (18). The authors also present a small molecule that selectively abrogates the growth of transformed cells, by targeting GAC, without impairing the growth of normal cells. Here, working with isoform-specific antibodies, we showed that both KGA and GAC protein levels are enhanced in breast tumor tissues, but only GAC was located in the mitochondria of tumor cell lines.

Named after the discovery of its enzymatic activity (31), mammalian glutaminases turned out to be more complex proteins, with a distinctive combination of additional motifs and functional domains. A consensus sequence of transit peptides that directs the enzyme to the mitochondria can be identified in the first 16 amino acids of GAC and KGA. Therefore, the result presented here demonstrating the localization of KGA in the cytoplasm of the cell lines studied as a likely full-length precursor form of $72-74 \mathrm{kDa}$, is particularly striking. A possible explanation however, might come from the C-terminal portions, which share only $12 \%$ sequence identity. KGA is predicted to contain three ankyrin repeats which exclusively function to mediate protein-protein

\begin{tabular}{|c|c|c|c|c|c|c|c|}
\hline \multirow{7}{*}{ 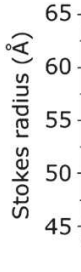 } & \multicolumn{2}{|c|}{$\begin{array}{lll}\nabla & 0 \mathrm{mM} \mathrm{K} \mathrm{K}_{2} \mathrm{HPO}_{4} \\
\nabla & 20 \mathrm{mM} \mathrm{K}_{2} \mathrm{HPO}_{4} \\
\end{array}$} & \multirow[t]{2}{*}{$\cdots$ Tetramer } & \multirow{2}{*}{$\begin{array}{c}\text { KGA, nM } \\
25\end{array}$} & \multirow{2}{*}{$\frac{\mathrm{K}_{\mathrm{m} \cdot \mathrm{mM}}}{11.93 \pm 0.48}$} & \multirow{2}{*}{$\frac{k_{\text {cat. }} s^{-1}}{1.46 \pm 0.05}$} & \multirow{2}{*}{ 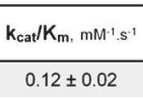 } \\
\hline & \multirow{4}{*}{$\nabla$} & \multirow{3}{*}{$\nabla \nabla$} & & & & & \\
\hline & & & \multirow{3}{*}{$\vec{\nabla}$} & 50 & $10.44 \pm 0.35$ & $0.98 \pm 0.04$ & $0.10 \pm 0.01$ \\
\hline & & & & 75 & $8.37 \pm 0.44$ & $0.71 \pm 0.02$ & $0.09 \pm 0.01$ \\
\hline & & & & 100 & $7.66 \pm 0.48$ & $0.65 \pm 0.01$ & $0.08 \pm 0.01$ \\
\hline & & Tाrm & Intrm & 150 & $5.84 \pm 0.43$ & $0.55 \pm 0.01$ & $0.09 \pm 0.01$ \\
\hline & & 1 & 0.1 & 200 & $5.46 \pm 0.29$ & $0.52 \pm 0.01$ & $0.09 \pm 0.01$ \\
\hline
\end{tabular}

Fig. 5. Concentration-dependent oligomerization and activation profile of KGA. This isoform responds much more slowly than GAC to increases in protein concentration regarding shifts in the equilibrium towards species of higher Stokes radius. Furthermore, the addition of phosphate has no effects on the overall profile (left box). The slowed response is also reflected in less significant changes in the enzyme's $K_{m}$ (right box), when compared to GAC (Fig. 4C). interactions and have been found in proteins of diverse function such as cell-cycle regulators, transcriptional initiators, cytoskeletal proteins, ion transporters, and signal transducers (32). Furthermore, aside from the N-terminal NR box motif in all three glutaminase isozymes, as the structure of GAC presented here confirms, the last five amino acids in the KGA sequence (LDGLL) may also serve as a second NR box. Hence, it would come as no surprise if the involvement of KGA in processes taking place outside the mitochondrial boundaries is soon demonstrated. Furthermore, it has already been shown that LGA, which also may contain one NRbox and a C-terminal ankyrin repeat, can localize in the nuclei of neuronal cells (22). Apart from the strong influence on the catalytic activity of GAC, no function can be predicted for its 53 amino acid long $\mathrm{C}$ terminus, based on the current knowledge on protein motifs and domains. In this context, GAC might be more relevant for the anaplerosis of the TCA cycle.

GLS1 Mechanism of Activation. Early biochemical studies of the kidney-type isozyme reported that mitochondrial glutaminases are mostly found as inactive dimers in the organelle and that the presence of phosphate correlates with changes leading to tetramerization and enzyme activation $(26,27)$. We have described here crystal structures of GAC tetramers in different bound states, and shown that the same tetramer is found in solution in the presence or absence of phosphate. Tetramerization, a concentration-dependent event enhanced by phosphate, is the main cause of increasing protein affinity for the substrate due to the opening of a so-called gating loop. Binding of the adjacent Phe 327 to the tetramer interface stabilizes the open form of the loop permitting the diffusion of substrate into the active site, thus providing a structural correlation between the cooperative oligomer activation and gating access to the active site. Concomitantly, the presence of phosphate plays the central role in increasing the turnover rates of the enzyme. Enzyme inhibition by glutamate has been reported for the kidney isoform of GLS1 (29). Furthermore, Sayre and Roberts showed in 1958 that glutamate inhibition of glutaminases was found to be competitive with phosphate (33). In this sense, we show with our crystal structures that Pi competes with glutamate for the cationic active site, accelerating product exchange and at the same time avoiding enzyme inhibition as product accumulates. While the described mechanism is shared between KGA and GAC isoforms, as they have the same glutaminase domain, it is possible that direct interactions between the GAC Cterminal region and the active site (which were not captured in our crystal structures) might occur to enhance catalysis.

Inorganic Phosphate Levels as a Sensor for Glutamine-Based Anaplerosis. GAC was first identified and found overexpressed in the human breast carcinoma cell line TSE (7). Subsequent work reported elevated GAC mRNA levels in tumors when compared to normal cell lines $(15,16)$. These observations, taken together with the work of Gao, et al. (17) and Wang, et al. (18), led us to ask whether this isoform might have intrinsic catalytic properties which allow it to perform better within the cancer microenvironment. Mammalian GA activity has been described as sensitive to inorganic phosphate (Pi), with KGA being activated by it and LGA being less sensitive $(8,9)$. To evaluate side-by-side the three reported glutaminases, we produced recombinant proteins and performed the activity assays at increasing amounts of $\mathrm{Pi}$, up to $50 \mathrm{mM}$. We have confirmed that KGA and LGA's individual responses to $\mathrm{Pi}$ are quite distinct one from another, but, surprisingly, GAC presented the highest efficiency $\left(k_{\text {cat-app }} / K_{m \text {-app }}\right)$ towards L-glutamine at higher concentrations of Pi. To our knowledge there is no data available in the literature concerning the mitochondrial levels of inorganic phosphate in tumor cells. It has been shown, however, that in guinea pig hearts the cellular concentration of Pi changes from 1.7 , to 7.1 and $13.9 \mathrm{mM}$, in going from normal to mildly hypoxic to severely hypoxic conditions, respectively (34). Taking into consideration the changes 
in mitochondrial homeostasis due to hypoxia for instance, the reduction of $\mathrm{F}_{1} \mathrm{~F}_{o}$ ATPase activity (35), which uses Pi to produce ATP, may lead to local levels of inorganic phosphate reaching even higher concentrations. Surviving hypoxic conditions is one of the main driving forces in the selection that leads to cancer progression. In this sense, we hypothesize that the accumulation of inorganic phosphate in the mitochondria is the trigger for increased GAC-based glutaminase activity. Under these circumstances, GAC may provide for the increased metabolic and biosynthetic needs, thus conferring selective advantage to malignant cells. Therefore, drug-based therapies specifically targeting the mitochondrial metabolism of glutamine seem more likely to succeed if developed to be GAC specific.

\section{Material and Methods}

Tissue Array and Cell Culture. Human normal and tumor breast tissue arrays (US Biomax, Inc.) were subjected to immunohystochemical analysis with KGA and GAC antibodies according to the manufacturer's protocol. Five types of human cancer cells lines, from breast (SKBR3 and MDA-MB231), prostate (PC3 and DU145), and lung (A549), were cultured in RPMI medium 1640 (Invitrogen) supplemented with 10\% FBS (Invitrogen), at $37{ }^{\circ} \mathrm{C}$ with $5 \% \mathrm{CO}_{2}$. Details can be found in the SI Text.

Immunoblot and Imunofluorescence. KGA specific monoclonal antibody targeting to KGA`s unique $\mathrm{C}$ terminus was acquired from Abnova (clone 5C4). GAC-specific polyclonal purified antibody was custom made by Genscript using the peptide CKLDPRREGGDQRHS. Blotting and fluorescence were performed using standard protocols. More details in the SI Text.

Heterologous Glutaminases. Rat KGA (Met128-Leu674) cloned in pET15b was previously published by the laboratory of Norman

1. Warburg $O$ (1956) On the origin of cancer cells. Science 123:309-314.

2. Hsu PP, Sabattini DM (2008) Cancer cell metabolism: Warburg and beyond. Cell 134:703-707.

3. Heiden MG, Cantley LC, Thompson CB (2009) Understanding the Warburg Effect: the metabolic requirements of cell proliferation. Science 324:1029-1036.

4. DeBerardines RJ, Cheng T (2010) Q's next: the diverse functions of glutamine in metabolism, cell biology and cancer. Oncogene 29:313-324.

5. Aledo JC, Gómez-Fabre PM, Olalla L, Márquez J (2000) Identification of two human glutaminase loci and tissue-specific expression of the two related genes. Mamm Genome 11:1107-1110.

6. Curthoys NP, Kuhlenschmidt T, Godfrey SS (1976) Phosphate-dependent glutaminase from rat kidney. Cause of increased activity in response to acidosis and identity with glutaminase from other tissues. Arch Biochem Biophys 174:82-89.

7. Elgadi KM, et al. (1999) Cloning and analysis of unique human glutaminase isoforms generated by tissue-specific alternative splicing. Physiol Genomics 1:51-62.

8. Campos-Sandoval JA, et al. (2007) Expression of functional human glutaminase in baculovirus system: affinity purification, kinetic and molecular characterization. Int J Biochem Cell Biol 34:765-773.

9. Kenny J, et al. (2003) Bacterial expression, purification, and characterization of rat kidney-type mitochondrial glutaminase. Protein Expres Purif 31:140-148.

10. Seltzer MJ, et al. (2010) Inhibition of glutaminase preferentially slows growth of glioma cells with mutant IDH1. Cancer Res 70:8981-8987.

11. Dang CV (2010) Glutaminolysis: supplying carbon or nitrogen or both for cancer cells? Cell Cycle 9:3884-3886.

12. Wise DR, Thompson CB (2010) Glutamine addiction: a new therapeutic in cancer. Trends Biochem Sci 35:427-433.

13. Lobo C, et al. (2000) Inhibition of glutaminase expression by antisense mRNA decreases growth and tumourigenicity of tumour cells. Biochem J 348:257-261.

14. Szeliga M, et al. (2005) Lack of expression of the liver-type glutaminase (LGA) mRNA in human malignant gliomas. Neuroscience Lett 374:171-173.

15. Szeliga M, et al. (2008) Relative expression of mRNAS coding for glutaminase isoforms in CNS tissues and CNS tumors. Neurochem Res 33:808-813.

16. Turner A, McGivan JD (2003) Glutaminase isoform expression in cell lines derived from human colorectal adenomas and carcinomas. Biochem J 370:403-408.

17. Gao P, et al. (2009) c-Myc suppression of miR-23a/b enhances mitochondrial glutaminase expression and glutamine metabolism. Nature 458:762-765.

18. Wang JB, et al. (2010) Targeting mitochondrial glutaminase activity inhibits oncogenic transformation. Cancer Cell 18:207-219.
Curthoys (9). GAC (Met128-Ser603) and LGA (Leu72-Val602) were amplified from a mouse fetal brain tissue cDNA library and cloned into the pET28a plasmid (Novagen). Standard heterologous protein expression and liquid chromatography techniques were used (see SI Text for details).

Crystallization and X-Ray Crystallography. Crystallization of the GAC construct is described in detail in the SI Text. X-ray diffraction datasets were obtained at beamlines X12-C at NSLS (ligandfree crystals), F-1 at CHESS (phosphate-bound crystals) and W02B-MX2 at LNLS (L-glutamate-bound crystals). Details of data processing, phasing and model refinement can be found in SI Text.

Enzyme Assays. The L-Glutamate Dehydrogenase-based (GDH), two-step Glutaminase protocol, as previously published (9), was adapted into a streamlined assay that could be followed in realtime and performed on a plate reader (SI Text).

Small Angle X-Ray Scattering. SAXS data for GAC, in the presence and absence of phosphate, was collected at the D01A-SAXS1 beamline at LNLS. Detailed description of data collection parameters and processing can be found in SI Text.

ACKNOWLEDGMENTS. We thank Dr. Richard Cerione and his laboratory, at Cornell University, for reagents and useful discussions. We thank Drs. Alessandra Girasol, Marcos Navarro and Andrew Leslie and the staff of the beamlines used in this work. We thank Dr. José Xavier Neto for stimulating discussions and critical reading of the manuscript. This work was supported by Fundação de Amparo à Pesquisa do Estado de São Paulo under grants 2010/05003-0 (A.L.B.A.), 2009/10875-9 (S.M.G.D.), and fellowship 2010/05987-0 (A.C.). We thank LNBio, for financial support and access to all facilities (LPP, LEC, LBE, and Robolab).

19. Suzuki S, et al. (2010) Phosphate-activated glutaminase (GLS2), a p53-inducible regulator of glutamine metabolism and reactive oxygen species. Proc Natl Acad Sci USA 107:7461-7466.

20. Hu W, et al. (2010) Glutaminase 2:a novel p53 target gene regulating energy metabolism and antioxidant function. Proc Natl Acad Sci USA 107:7455-7460.

21. Plevin MJ, Mills MM, Ikura M (2005) The LXXLL motif: a multifunctional binding sequence in transcriptional regulation. Trends Biochem Sci 30:66-69.

22. Olalla L, et al. (2002) Nuclear localization of L-type glutaminase in mammalian brain. J Biol Chem 277:38939-38944.

23. Brown $G$, et al. (2008) Functional and structural characterization of four glutaminases from Escherichia coli and Bacillus subtilis. Biochemistry 47:5724-5735.

24. Voss NR, Gerstein M (2010) 3V: cavity, channel and cleft volume calculator and extractor. Nucleic Acids Res 38:W555-W562.

25. Krissinel E, Henrick K (2007) Inference of macromolecular assemblies from crystalline state. J Mol Biol 372:774-797.

26. Godfrey S, Kuhlenschmidt T, Curthoys NP (1977) Correlation between activation and dimer formation of rat renal phosphate dependent glutaminase. J Biol Chem 252:1927-1931.

27. Morehouse RF, Curthoys NP (1981) Properties of rat renal phosphate-dependent glutaminase coupled to Sepharose. Evidence that dimerization is essential for activation. Biochem J 193:709-716.

28. Garcia de la Torre J, Huertas ML, Carrasco B (2000) Calculation of hydrodynamic properties of globular proteins from their atomic-level structure. Biophys $J$ 78:719-730.

29. Curthoys NP, Watford M (1995) Regulation of glutaminase activity and glutamine metabolism. Annu Rev Nutr 15:133-159.

30. Kovacevic Z, McGivan JD (1983) Mitochondrial metabolism of glutamine and glutamate and its physiological significance. Physiol Rev 63:547-605.

31. Krebs HA (1935) Metabolism of aminoacids: the synthesis of glutamine from glutamic acid and ammonia, and the enzymic hydrolysis of glutamine in animal tissues. Biochem J 29:1951-1969.

32. Li J, Mahajan A, Tsai MD (2006) Ankyrin repeat: a unique motif mediating proteinprotein interactions. Biochemistry 45:15168-15178.

33. Sayre FW, Roberts E (1958) Preparation and some properties of a phosphateactivated glutaminase from kidneys. J Biol Chem 233:1128-1134.

34. Gorman MW, He MX, Hal CS, Sparks HV (1997) Inorganic phosphate as regulator of adenosine formation in isolated guinea pig hearts. Am J Physiol 272:H913-H920.

35. Nguyen T, Johnson JA (2008) Delta protein kinase C interacts with the $d$ subunit of the F1F0 ATPase in neonatal cardiac myocytes exposed to hypoxia or phorbol ester. Implications for $\mathrm{F}_{11} \mathrm{~F}_{00}$ ATPase regulation. J Biol Chem 283:29831-29840. 


\title{
Active Glutaminase C Self-assembles into a Supratetrameric Oligomer That Can Be Disrupted by an Allosteric Inhibitor
}

Received for publication, July 14, 2013, and in revised form, August 6, 2013 Published, JBC Papers in Press, August 8, 2013, DOI 10.1074/jbc.M113.501346

\author{
Amanda Petrina Scotá Ferreira $^{\ddagger 1}$, Alexandre Cassago ${ }^{\S 1}$, Kaliandra de Almeida Gonçalves ${ }^{\ddagger 1}$, Marília Meira Dias , $^{\ddagger}$ \\ Douglas Adamoski ${ }^{\ddagger}$, Carolline Fernanda Rodrigues Ascenção ${ }^{\ddagger}$, Rodrigo Vargas Honorato ${ }^{\ddagger}$, \\ Juliana Ferreira de Oliveira ${ }^{\ddagger}$, Igor Monteze Ferreira ${ }^{\ddagger}$, Camila Fornezari $^{\ddagger}$, Jefferson Bettini ${ }^{\S}$, \\ Paulo Sérgio Lopes Oliveira ${ }^{\ddagger}$, Adriana Franco Paes Leme ${ }^{\ddagger}$, Rodrigo Villares Portugal ${ }^{\S}$, \\ Andre Luis Berteli Ambrosio ${ }^{\neq 2,3}$, and Sandra Martha Gomes Dias ${ }^{\neq 2,4}$ \\ From the Laboratórios Nacionais de ${ }^{\ddagger}$ Biociências e ${ }^{\S}$ Nanotecnologia, Centro Nacional de Pesquisa em Energia e Materiais, \\ Campinas-SP 13083-100, Brazil
}

Background: GAC supplies for increased metabolic needs of tumors because of exclusive localization and kinetic properties.

Results: Higher than tetramer oligomers are the active form in in vitro and in cellular assays. Bis-2-(5-phenylacetamido-1,3,4thiadiazol-2-yl)ethyl sulfide disrupts oligomers.

Conclusion: A novel molecular mechanism for GAC activation is proposed.

Significance: The data affect the development of therapies targeting GAC in tumors, with emphasis on allosteric inhibitors.

The phosphate-dependent transition between enzymatically inert dimers into catalytically capable tetramers has long been the accepted mechanism for the glutaminase activation. Here, we demonstrate that activated glutaminase C (GAC) self-assembles into a helical, fiber-like double-stranded oligomer and propose a molecular model consisting of seven tetramer copies per turn per strand interacting via the $\mathrm{N}$-terminal domains. The loop ${ }^{321} \mathrm{LRFNKL}^{326}$ is projected as the major regulating element for self-assembly and enzyme activation. Furthermore, the previously identified in vivo lysine acetylation ( $\mathrm{Lys}^{311}$ in humans, Lys $^{316}$ in mouse) is here proposed as an important down-regulator of superoligomer assembly and protein activation. Bis-2(5-phenylacetamido-1,3,4-thiadiazol-2-yl)ethyl sulfide, a known glutaminase inhibitor, completely disrupted the higher order oligomer, explaining its allosteric mechanism of inhibition via tetramer stabilization. A direct correlation between the tendency to self-assemble and the activity levels of the three mammalian glutaminase isozymes was established, with GAC being the most active enzyme while forming the longest structures. Lastly, the ectopic expression of a fiber-prone superactive GAC mutant in MDA-MB 231 cancer cells provided considerable

\footnotetext{
* This work was supported by Fundação de Amparo à Pesquisa do Estado de São Paulo (FAPESP) under Grants 2009/10875-9 (to S. M. G. D.) and 2010/ 05003-0 and 2012/14298-9 (to A. L. B. A.) and Fellowships 2010/05987-0 (to A. P. S. F.), 2010/05987-0 (to A. C.), 2011/06654-7 (to K. A. G.), and 2009/ 54067-3 (to A. F. P. L.). This work was also supported in part by the Laboratório Nacional de Biociências.

The atomic coordinates and structure factors (code 4jkt) have been deposited in the Protein Data Bank (http://wwpdb.org/)

${ }^{1}$ These authors contributed equally to this work.

2 These authors contributed equally to this work.

${ }^{3}$ To whom correspondence may be addressed: LNBio, CNPEM, Rua Giuseppe Máximo Scolfaro, 10.000, Pólo Il de Alta Tecnologia, Campinas, SP, 13083 100, Brazil. Tel.: 55-19-3512-1115; Fax: 55-19-3512-1004; E-mail: andre. ambrosio@lnbio.cnpem.br.

${ }^{4}$ To whom correspondence may be addressed: LNBio, CNPEM, Rua Giuseppe Máximo Scolfaro, 10.000, Pólo Il de Alta Tecnologia, Campinas, SP, 13083 100, Brazil. Tel.: 55-19-3512-1115; Fax: 55-19-3512-1004; E-mail: sandra. dias@Inbio.cnpem.br.
}

proliferative advantages to transformed cells. These findings yield unique implications for the development of GAC-oriented therapeutics targeting tumor metabolism.

Cancer cells have a well established dependence on glutamine metabolism to support their highly proliferative status. Apart from acting as a source for nitrogen as well as reductive power, its anabolic carbon skeletons can be siphoned from the TCA cycle to be used as building blocks for the growing and dividing cells $(1,2)$. Both Myc and Rho GTPases have been shown to stimulate glutaminase $\mathrm{C}(\mathrm{GAC}){ }^{5}$ an isozyme that possesses a distinct cellular localization as well as activation levels purported to provide the aforesaid proliferative advantage to cancer cells (3-5).

We have recently described the structural determinants of the phosphate-dependent activation mechanism of GAC, based on the tetramerization-induced lifting of a so-called gating loop ( ${ }^{321}$ LRFNKL $^{326}$; NCBI sequence NP_001106854.1), which controls substrate accessibility to the active site. We showed that phosphate binds inside the catalytic pocket, resulting in allosteric stabilization of tetramers and facilitating substrate entry by outcompeting with the product, glutamate, to guarantee enzyme cycling (5). Additionally, recent publications have provided structural insights into glutaminase inhibition by making use of the small molecules BPTES and 968 (6-9). Nevertheless, the precise descriptions of their modes of inhibition are still lacking.

Renewed interest in cancer metabolism has prompted an innovative warfront against metabolic enzymes, aiming at the development of alternative and efficient therapeutic opportunities. Glutaminase $C$ is a key target in this sense $(2,4,10,11)$,

${ }^{5}$ The abbreviations used are: GAC, glutaminase C; BPTES, bis-2-(5-phenylacetamido-1,3,4-thiadiazol-2-yl)ethyl sulfide; TEM, transmission electron microscopy; KGA, kidney-type glutaminase; LGA, liver-type glutaminase; DSS, disuccinimidyl suberate. 


\section{Supratetrameric Oligomerization-dependent GAC Activation}

and the need for new and accurate biochemical and structural information to speed up and improve the development of successful therapies is therefore essential. In this regard, we now provide novel information demonstrating that the assembly of higher order, fiber-like GAC oligomers, henceforth termed the GAC superstructure, is necessary for proper enzyme activation both in vitro and in a cancer cell model. First, we demonstrate that the superstructure is mandatorily present when GAC is in the active form, as shown by negatively stained samples analyzed by transmission electron microscopy (TEM). The tendency toward the superstructure correlates well with the activation levels induced by phosphate among GAC and the other two mammalian glutaminase isozymes: the kidney-type glutaminase (KGA) and the liver-type glutaminase (LGA). Although LGA is a synonym for the GLS2 glutaminase, KGA and its splicing variant GAC are both usually indistinguishably referred to as GLS1. Moreover, we observe that the addition of the GLS1 inhibitor BPTES hampers protein polymerization by stabilizing inactive tetramers.

Further research identified a subset of key residues involved in the superstructure formation process. They are located in the gating loop, as well as at the $\mathrm{N}$ and $\mathrm{C}$ termini, which have been previously shown to be key structural features for enzyme activation $(5,12)$. One specific gating loop mutant, GAC.K325A, both assembles into the superstructure and shows a 600-fold enhancement in catalytic efficiency toward L-glutamine, even in the absence of phosphate. Conversely, GAC.R322A, also at the gating loop, abrogated protein activation and impeded superstructure formation. A previously identified in vivo posttranslational modification of human GLS1 (13), the acetylation of Lys ${ }^{316}$ (equivalent to Lys ${ }^{311}$ in human), was also studied in this context. We show that the acetylation mimetic GAC.K316Q does not assemble into higher order oligomers, and this modification likely inhibits protein activity in cells. By combining data from point mutants, TEM, MS, and computational biology, we offer a low resolution model for the superstructure assembly. The superstructure is based on a double-stranded helix, with each strand containing tetramers interacting with each other via the $\mathrm{N}$ terminus domain. Lastly, we demonstrate that MDA-MB 231 cells silenced for the endogenous GAC expression and stably expressing an ectopic fiber-prone superactive mutant, proliferate more, consume higher amounts of glutamine, and grow bigger than the wild-type and mock transformed cells. Our results shed new light on the molecular mechanism of phosphate-dependent activation of the glutaminases and highlight the importance of the development of allosteric inhibitors when targeting GAC in tumors.

\section{EXPERIMENTAL PROCEDURES}

Protein Production, Enzymatic Assay, Size Exclusion Serial Dilution, and Site-directed Mutagenesis-Recombinant protein expression and purification, the streamlined glutaminase activity assay, and the size exclusion analysis of serial dilutions were performed as previously published (5). Point mutants were generated with the QuikChange II site-directed mutagenesis kit (Stratagene) following the manufacturer's instructions. The inhibition assays using BPTES (kindly provided by Dr. Chi Van Dang, Abramson Cancer Center, University of Pennsylva- nia, Philadelphia, PA) were done with GAC or GAC.K325A at 5 $\mathrm{nM}$ and BPTES diluted in $\mathrm{Me}_{2} \mathrm{SO}$, the last always at a $0.5 \%$ final concentration. Measurements were done in triplicate and analyzed using GraphPad Prism 5.00 (GraphPad Software) and Origin 8.1 (Originlab). The parameters of the dose-response curve were determined by fitting an error bar-weighted logistic function, in the form of $y=A_{2}+\left(A_{1}-A_{2}\right) /\left(1+\left(x / x_{0}\right)^{\wedge} p\right)$, where $A_{1}$ is the initial apparent turnover rate (absence of inhibitor), $A_{2}$ is the turnover rate at saturating concentrations of inhibitor, $x_{0}$ is the half-maximum inhibitory concentration, or $\mathrm{IC}_{50}$, and $p$ is the Hill slope.

Transmission Electron Microscopy - For visualization of negatively stained grids, protein samples, at a concentration ranging from 0.5 to $1 \mu \mathrm{M}$, were deposited onto glow-discharged holey carbon-coated grids for $60 \mathrm{~s}$ followed by two steps of blotting and staining with $2 \%$ uranyl acetate. Images were acquired between -1 - and -3 - $\mu$ m defocus at 15,000-80,000 $\times$ magnification using a Jeol JEM-2100 operating at $200 \mathrm{kV}$ and recorded on a F-416 CMOS camera (Tietz Video and Image Processing Systems).

Crystallization and X-ray Crystallography-Crystallization experiments were performed at $291 \mathrm{~K}$ using the conventional sitting drop vapor diffusion technique. Drops were made by mixing three parts of protein (at $3.3 \mathrm{mg} / \mathrm{ml}$ ) to one of well solution, containing 17\% PEG 3350, $0.2 \mathrm{M} \mathrm{NaCl}$, and $0.1 \mathrm{~m}$ Bis-Tris, $\mathrm{pH}$ 6.5. Clusters of plates were observed after 5 days and used as seeds for a standard streak seeding in a mother liquor solution containing $11 \%$ PEG 3350, $0.2 \mathrm{M} \mathrm{NaCl}$, and $0.1 \mathrm{M}$ Bis-Tris, $\mathrm{pH}$ 6.5. Before data collection at cryogenic temperature $(100 \mathrm{~K})$, harvested crystals were cryoprotected with $10 \%$ ethylene glycol added to the mother liquor. X-ray diffraction data were obtained at the D03B-MX1 Beamline at Laboratório Nacional de Luz Síncrotron in Brazil. The data were processed using Mosflm (14) and Scala (15). The first set of phases was obtained by the molecular replacement as implemented in Phaser (16), using the data set from the ligand-free form of GAC, available under Protein Data Bank code 3ss3 (5). Positional and B-factor refinement cycles were carried out with Phenix (17). Manual building of the extra portions and real space refinement, including Fourier electron density map inspection, were performed with Coot (18). The overall stereochemical quality of the final models and the agreements between them and experimental data were assessed by the program Molprobit (19) and the appropriate Coot routines.

Cross-linking Analysis of GAC Complexes by LC-MS/MSGAC complexes were reduced (5 mM dithiothreitol, $25 \mathrm{~min}$ at $56{ }^{\circ} \mathrm{C}$ ), alkylated (14 $\mathrm{mm}$ iodoacetamide, $30 \mathrm{~min}$ at room temperature in the dark), and digested with trypsin (Promega). The samples were lyophilized in a vacuum concentrator and reconstituted in $0.1 \%$ formic acid. Then $4.5 \mu \mathrm{l}(1 \mu \mathrm{g})$ of the resulting peptide was analyzed on an LTQ Velos Orbitrap mass spectrometer (Thermo Fisher Scientific) coupled with LC-MS/MS by an EASY-nlC system (Thermo Fisher Scientific) through a Proxeon nanoelectrospray ion source. Peptides were separated by a $2-90 \%$ acetonitrile gradient in $0.1 \%$ formic acid using a pre-column EASY-Column $(2 \mathrm{~cm} \times 100-\mu \mathrm{m}$ inner diameter, $5-\mu \mathrm{m}$ particle size) and an analytical column PicoFrit Column $(20 \mathrm{~cm}-75-\mu \mathrm{m}$ inner diameter, 5 - $\mu \mathrm{m}$ particle size; New Objec- 


\section{Supratetrameric Oligomerization-dependent GAC Activation}

tive) at a flow rate of $300 \mathrm{nl} / \mathrm{min}$ over $65 \mathrm{~min}$. The nanoelectrospray voltage was set to $2.2 \mathrm{kV}$, and the source temperature was $275{ }^{\circ} \mathrm{C}$. The instrument methods in LTQ Velos Orbitrap were set up in the data-dependent acquisition mode of higher-energy collisional dissociation fragmentation. The full scan MS spectra $(m / z 300-1,600)$ were acquired in the Orbitrap analyzer after accumulation to a target value of $1 \times e^{6}$. The resolution in the Orbitrap system was set to $r=60,000$, and the five most intense peptide ions with charge states of $\geq 2$ were sequentially isolated to a target value of 50,000 and fragmented in HCD with normalized collision energy of $40 \%$ with the resolution in the Orbitrap system was set to $r=7,500$ for MS/MS. The signal threshold for triggering an MS/MS event was set to 80,000 counts, and an activation time of $0.1 \mathrm{~ms}$ was used. Dynamic exclusion was enabled with exclusion size list of 400, exclusion duration of $60 \mathrm{~s}$, and repeat count of 2 . For cross-linking analysis, the raw data files generated by Xcalibur v.2.1 (Thermo Fisher Scientific) were converted to a peak list format (mgf) using Proteome Discoverer version 1.3 (Thermo Fisher Scientific). The mgf files were analyzed in MassMatrix software to automatically search chemical cross-linkage against database containing the GAC amino acid sequences. The parameters for cross-linking analysis were carbamidomethylation $(+57.021460 \mathrm{Da})$ as fixed modification, oxidation of methionine $(+15.99491 \mathrm{Da})$ as variable modifications, chemical crosslinked with disuccinimidyl suberate-DSS (138.06808 Da) noncleavable by enzymes, four trypsin missed cleavages, and a tolerance of $10 \mathrm{ppm}$ for precursor and $0.02 \mathrm{Da}$ for fragment ions (20). Potential cross-linked peptides were manually validated. This experiment was independently performed four times for the tetramer form and seven times for the superoligomer form. Unique lysine linkages (underlined in the following peptides) were only observed in the tetramer samples, between residues Lys $^{181}$ and Lys ${ }^{207}(\alpha$-KCVQSNIVLLTQAFR and $\beta$-LKECMDMLR), Lys $^{202}$ and Lys ${ }^{578}$ ( $\alpha$-LTLQTTSDGVMLDKDLFK and $\beta$-DTVWKK), and Lys ${ }^{403}$ and Lys ${ }^{512}(\alpha$-SGVAGGILLVVPNVMGMMCWSPPLDKMGNSVK and $\beta$-EKK).

Computational Biology - To obtain a model of the glutaminase fiber, we applied a previously developed rigid body docking algorithm restrained by experimental DSS cross-linking data (20). Initially, we reconstructed both the $\mathrm{N}$ - and C-terminal regions of the monomers using a loop reconstruction routine and placed a copy of the tetramer, namely the ligand domain, on the $\mathrm{N}$-terminal of the receptor domain. Using only the exclusive intermonomer linkage that was observed in our reconstructed model $\left(\right.$ Lys $^{181}-$ Lys $^{207}$ ), we selected the decoy that was in the lowest energy range and within $11 \AA$ of lysine pair distance.

Cell Assays-MDA-MB 231 cells were purchased from ATCC (initial passage of 29) and cultivated in RPMI 1640 medium (Cultilab, Campinas, Brazil) supplemented with $10 \%$ fetal bovine serum (Cultilab). The pcDNA3.1/V5-His-hGAC (GAC-V5) clone was kindly provided by Dr. Richard Cerione (Cornell University, Ithaca, NY), and the mutation K320A (equivalent to $\mathrm{K} 325 \mathrm{~A}$ in the mouse gene) performed with the QuikChange II site-directed mutagenesis kit (GAC.K325A-V5) following the manufacturer's instructions. Lipofectaminetransfected cells were G418 selected for stable expression, which was confirmed by Western blotting. The mock control was obtained by transfecting cells with empty vector. To accomplish the endogenous GAC knockdown, the same cell clones were transduced with lentiviral particles containing pLKO-shGAC plasmid (forward, 5' -CCGGCCTCTGTTCTGTCAGAGTTCTCGAGAACTCTGACAGAACAGAGGTTTTTG-3', and reverse, 5' -AATTCAAAAACCTCTGTTCTGTCAGAGTTCTCGAGAACTCTGACAGAACAGAGG-3'), and a pool of cells was selected for puromicin resistance. The cells were lysed with $20 \mathrm{~mm}$ Tris- $\mathrm{HCl}, \mathrm{pH} 7.5,150 \mathrm{~mm} \mathrm{NaCl}, 1 \%$ Triton $\mathrm{X}$-100, 1 mм EDTA, 1 mм DTT, 1 mм $\mathrm{NaVO}_{4}, 1 \mathrm{~mm} \beta$-glycerol phosphate, $11 \mu \mathrm{g} \cdot \mathrm{ml}^{-1}$ aprotinin, $11 \mu \mathrm{g} \cdot \mathrm{ml}^{-1}$ pepstatin, and $1 \mathrm{mM}$ PMSF. The lysates were resolved by SDS-PAGE, and the proteins were transferred to polyvinylidene fluoride membranes. The membranes were incubated overnight with the primary antibodies diluted in $20 \mathrm{~mm}$ Tris, $135 \mathrm{~mm} \mathrm{NaCl}$, and $0.1 \%$ Tween 20. The primary antibodies were detected with horseradish peroxidaseconjugated secondary antibodies followed by exposure to Pierce SuperSignal West Pico Substrate. We used anti-V5 1:10,000 (Invitrogen), anti-GAC custom made by Genescript as previously described in Ref. 5 at $1 \mu \mathrm{g} \cdot \mathrm{ml}^{-1}$, anti-Vinculin 1:1,000 (Cell Signaling) and anti-VDAC 1:1,000 (Cell Signaling). As for the immunofluorescence and glutamine consumption studies, MDA-MB 231 cells were seeded in a 6-well plate (Becton Dickson) at a density of $2.5 \times 10^{-5}$ cells $^{\bullet} \mathrm{cm}^{-2}$, cultivated for $48 \mathrm{~h}$ at $37^{\circ} \mathrm{C}$ with $5 \%$ of $\mathrm{CO}_{2}$ and then fixated and permeabilized with $3.7 \%$ formaldehyde in PBS, $0.2 \%$ Triton X-100. The cells were blocked with 3\% BSA in PBS, $0.8 \%$ Triton $\mathrm{X}-100$, and incubated at room temperature for $1 \mathrm{~h}$, with anti-V5 1:20,000 diluted in 3\% BSA in PBS/0.8\% Triton X-100. Goat secondary anti-mouse-Alexa 633 (Invitrogen), diluted in blocking solution (1:200) was used to reveal ectopically expressed V5-tagged GAC. The nuclei and actin were stained with $2.5 \mu \mathrm{g} \cdot \mathrm{ml}^{-1}$ DAPI (Sigma) and phalloidin-Alexa 488 (1:40), respectively. Data were collected with the plate reader Fluorescence Microscope Operetta (PerkinElmer Life Sciences), and the cell number and area quantified were using the software Harmony 3.0. Glutamine consumption from the culture medium was assessed using the Bio-Profile Basic 4 (Nova Biomedical). BPTEStreated cells were allowed to attach for $24 \mathrm{~h}$ and then had the medium replaced by fresh medium added with $10 \mu \mathrm{m}$ of the inhibitor for $48 \mathrm{~h}$. For the whole cell lysate glutaminase activity assay, the cells were lysed by ressuspension in $25 \mathrm{~mm}$ Hepes, pH 8.0, 150 $\mathrm{mm} \mathrm{NaCl}, 1 \mathrm{~mm}$ EDTA, 0.01\% Triton X-100, and $1 \times$ Protease Inhibition Solution (Qiagen) followed by 20 strokes through an insulin needle. Glutaminase activity assay of the whole cell extracts was performed following the published streamlined assay (5), using $5 \mu \mathrm{g}$ of lysate/well and L-glutamine concentration of $7.5 \mathrm{~mm}$. Diameter of detached viable cells was measured by the Countess (Invitrogen) after trypsinization and trypan blue incubation.

In Cell Protein Cross-linking-Approximately $3 \times 10^{6}$ cells were seeded in $10-\mathrm{cm}$ plates and allowed to adhere overnight. The next day, the medium was removed, and the cells were washed twice with PBS and incubated for $24 \mathrm{~h}$ with $2 \mathrm{mM} \mathrm{L}$-photo-leucine and $4 \mathrm{~mm}$ L-photo-methionine (Pierce) in leucineand methionine-free DMEM supplemented with 10\% PBS-dialyzed FBS. After this incubation, the medium was removed, and cells were washed twice with PBS and then irradiated at $365 \mathrm{~nm}$ for $15 \mathrm{~min}$ in the Epi Chemi II Darkroom equipment (UVP Laboratory Products). The cells were harvested for lysis, and 


\section{Supratetrameric Oligomerization-dependent GAC Activation}
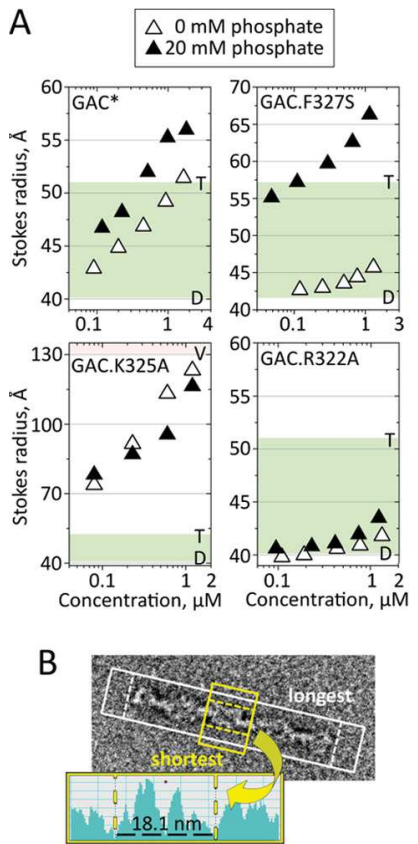

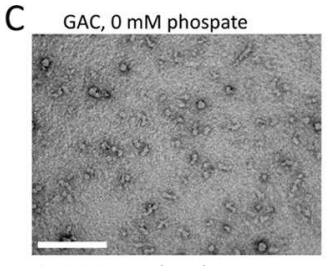

GAC, $20 \mathrm{mM}$ phosphate
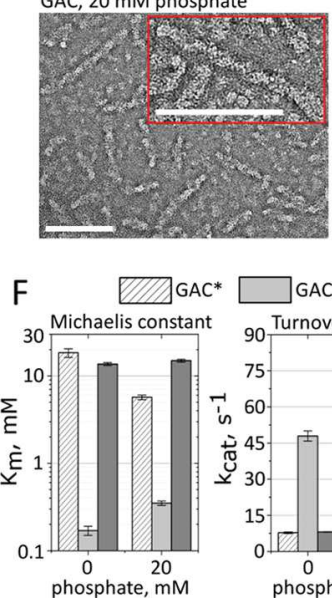

$\mathrm{D}$

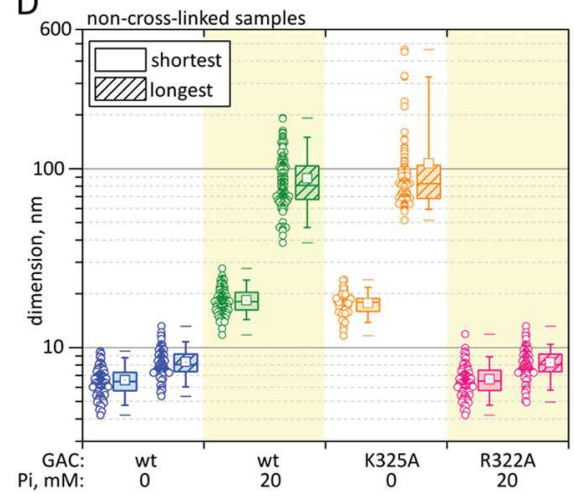

$\mathrm{E}$

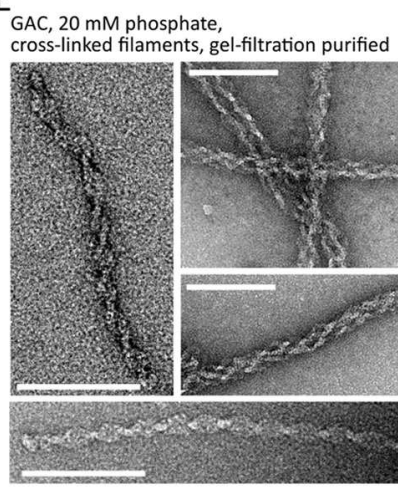

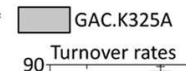

GAC.R322A
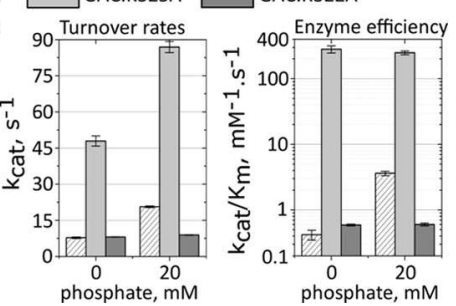

G

GAC.K325A, 0 mM phosphate
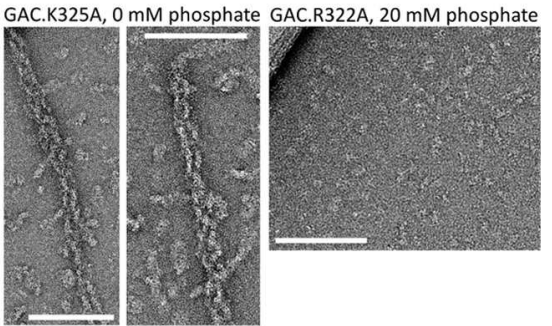

FIGURE 1. GAC polymerization is essential for enzymatic activation. $A$, size exclusion chromatography analysis of serial dilutions for wild-type and mutated GAC in the presence or absence of $20 \mathrm{~mm}$ phosphate. The green region delimits the expected Stokes radii between GAC dimers $(D)$ and tetramers $(T)$, calculated based on the crystal structure (3ss3) dimensions. The light purple region, delimited by V in the GAC.K325A graph, indicates the void volume of the gel-filtration column used. The asterisk indicates a previously published result for wild-type GAC (5). B, the software DigitalMicrograph (Gatan) was used to estimate the two orthogonal size distributions (short and long dimensions) of the wild-type and point mutant glutaminase particles, formed under the diverse conditions described in the main text (absence or presence of $20 \mathrm{~mm}$ phosphate and cross-linked versus non-cross-linked particles). C, supratetrameric organization of GAC upon the addition of $20 \mathrm{~mm}$ phosphate, a well known activator of GLS1 glutaminases. D, box plot and scatter representation of the two orthogonal dimensions for GAC wild-type and point mutants, as taken from the TEM micrographs. E, chemically cross-linked GAC superoligomers. Some of the observed filaments resemble lateral association between two simple filaments. F, GAC.K325A presents a much higher catalytic efficiency, already in the absence of phosphate, when compared with wild-type GAC and the inactive GAC.R322A. G, the high enzymatic efficiency of GAC.K325A correlates well with its tendency to selfassemble into rod-like polymers, regardless of the presence of the activator inorganic phosphate (left and middle panels) and DSS. Conversely, the catalytically inactive GAC.R322A protein remains in its tetrameric form, even in the presence of $20 \mathrm{~mm}$ phosphate (right panel). The scale bars represent $100 \mathrm{~nm}$.

cross-linked proteins were resolved by $3-15 \%$ step gradient SDS-PAGE (3, 9, and 15\% SDS-PAGE solutions prepared with 50:1 acrylamide:bisacrylamide mix, poured one after another in volume proportions of $1.5: 2: 1$ ). The immunoblotting was performed with the anti-V5 1:10,000 (Invitrogen) as described in the preceding section.

Estimation of Intracellular Glutamine Concentration in Breast Tumor Cells-From metabolomics experiments on tumor samples, Yuneva et al. (21) reported a relationship of 40 to hundreds of nanomoles of glutamine for each gram of protein. We have found that unattached GAC.K325A-V5, GAC-V5, and mock transformed MD-MBA 231 cells have average diameters of 13.3, 10.9, and $10.6 \mu \mathrm{m}$, respectively. Assuming a spherical shape for these cells, the following cell volume can be calculated: $1.2 \mathrm{nl}$ (GAC.K325A-V5 cells) and $0.6 \mathrm{nl}$ (GAC-V5 and mock cells). Using the Pierce BCA protein assay kit (ThermoScientific), we quantified an average of 0.23 grams of protein for $2 \times 10^{6}$ cells, sampling from the three cell clones. Based on the lowest detected glutamine amount from Yuneva et al. (21) of 40 $\mathrm{nmol} \mathrm{Gln} / \mathrm{g}$ of protein, we estimate that these cells contained between 3.7 and $7.4 \mathrm{~mm}$ glutamine.

Quantitative PCR-RNA samples were extracted using the kit RNAeasy Mini (Qiagen) following the manufacturer's instructions. cDNA synthesis and PCR amplification were performed with the kits SuperScript III first strand synthesis system for RT-PCR (Invitrogen) and Power SYBR Green PCR
Master Mix (Applied Biosystems), respectively, as instructed by the manufacturers. Samples were run on the Applied Biosystems 7500 real time PCR system and analyzed following the $2^{-\Delta \Delta C T}$ method. Primers used: (i) both endogenous and ectopic GAC: forward, 5'-GATCAAAGGCATTCCTTTGG-3', and reverse, 5'-TACTACAGTTGTAGAGATGTCC-3'; (ii) ectopic GAC only: forward, 5' -AGAATGGAAAGTCTGGGAGAGAAA-3', and reverse, 5' -CCGAGGAGAGGGTTAGGGATA3'; (iii) SN2: forward, 5'-GGCTTGGTAGTGTTTGCCAT-3', and reverse, $5^{\prime}$-GGGCAAAGAGTAAACCCACA-3; (iv) ASCT2: forward, 5' -ATGAAACACTTGGGCTAC-3', and reverse, 5' ATGACCGAAACAAGGAAA-3'; (v) rRNA 18 S: forward, 5' ATTCCGATAACGAACGAGAC-3', and reverse, 5' -TCACAGACCTGTTATTGCTC-3'.

\section{RESULTS}

Active GAC Forms a Rod-like Supratetrameric StructureWe have previously documented that wild-type GAC, when in the presence of its activator $P_{i}$, showed a tendency to form molecular species larger than tetramers and that this behavior was counteracted when the concentration of $\mathrm{NaCl}$, a known glutaminase inhibitor, was increased in the protein solution (5, 12). Although the structural nature of the higher order species remained elusive at that time, it was curious to note that there was a significantly major shift toward higher than tetramer olig- 


\section{Supratetrameric Oligomerization-dependent GAC Activation}

omers in the case of the activity-enhancer mutation F327S (GAC.F327S; Fig. 1A, top right panel).

In the course of further studies of the molecular mechanism of activation of mammalian glutaminase, we used TEM to better understand the self-assembly process. First, recombinant GAC (in the absence of $\mathrm{Pi}$ ) was used to set up negatively stained grids. Image analysis, after sampling $\sim 100$ randomly chosen particles, allowed the determination of two perpendicular size distributions (exemplified in Fig. 1B): a short dimension, with a mean size of $7 \pm 1 \mathrm{~nm}$, and a longer one of $8 \pm 1 \mathrm{~nm}$ (Fig. $1 C$, upper panel), both close to the expected dimensions for the dimer particle (5). In contrast, particles formed in the presence of $20 \mathrm{~mm}$ phosphate had a larger and more heterogeneous size distribution on the grid. Whereas the shorter dimension doubled on average (18 $\pm 3 \mathrm{~nm}$ ), there was clearly favored growth across the long dimension, averaging $88 \pm 31 \mathrm{~nm}$ (Fig. $1 C$, lower panel). The box chart with scatter plot for the size survey is shown in Fig. $1 D$.

The equilibrium between the GAC oligomeric species depends on protein concentration, phosphate, and $\mathrm{NaCl}$ (5). To circumvent the dissociative effects of protein dilution and work at appropriate protein concentrations for TEM characterization, superstructure assembly was stabilized by adding the cross-linking agent DSS in the presence of $20 \mathrm{~mm}$ phosphate and then purified by gel filtration. Under the conditions used, the superstructures eluted in the void volume of the column. The appropriate DSS concentration and time of incubation was previously established by a dose-response assay (data not shown). The negative-stained micrographs showed evidence for the formation of elongated, chain-like, nonbranched filaments, heterogeneous in length, that favored side-on adsorption to the carbon film (Fig. $1 E$ ). Some of the observed particles, such as those in the rightmost panels of Fig. $1 E$, seem to resemble side by side aggregation of simpler filaments (left and bottom panels).

We have previously identified the gating loop as essential for the phosphate-dependent activation process of the GLS1 isoforms (5). By replacing residues in the gating loop by alanine, we identified a point-mutation (GAC.K325A) that conferred a 670 -fold increase in catalytic efficiency over that found for the wild-type enzyme, even in the absence of inorganic phosphate (GAC.K325A $k_{\text {cat-app }} / K_{m \text {-app }}$ of $281.8 \mathrm{~mm}^{-1} \cdot \mathrm{s}^{-1}$ compared with $0.42 \mathrm{mM}^{-1} \cdot \mathrm{s}^{-1}$ for GAC) (Fig. $1 F$ ). Both negative staining TEM (Fig. 1G, left panel) and size exclusion chromatography (Fig. 1A, bottom left panel) confirmed a much greater particle size distribution for this mutant, even in non-cross-linked samples. For example, TEM analysis showed dimensions of $17 \pm 2$ and $107 \pm$ $79 \mathrm{~nm}$, for the short and long dimensions, respectively, in the absence of phosphate (Fig. 1D). More importantly, this mutant assembles into oligomers visually similar to the ones formed with the wild-type protein (Fig. 1E, rightmost panels), guaranteeing that the mutation is only enhancing the oligomerization capability. The K325A mutation uncouples the protein dependence on phosphate for activation and further confirms the positive correlation between the superstructure assembly and enzyme activation. On the other hand, a second point mutation within the gating loop, affecting $\mathrm{Arg}^{322}$ (termed GAC.R322A), was enough to generate a catalytically inactive mutant irre-

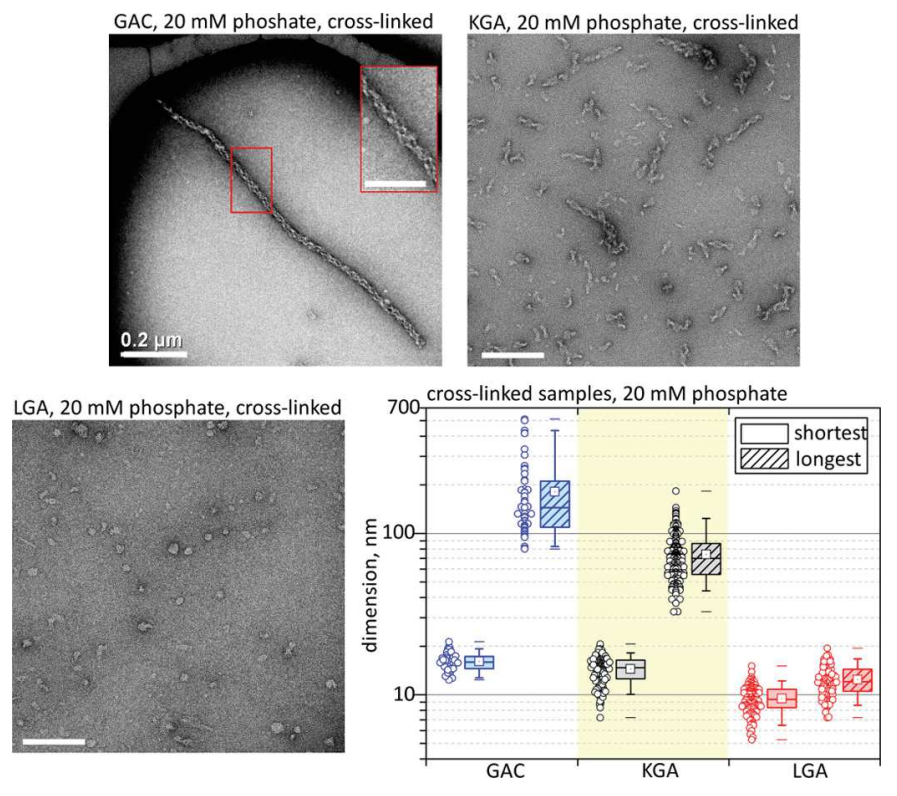

FIGURE 2. Glutaminase isozymes versus self-assembly tendency. TEM analysis of the three glutaminase isozymes, cross-linked after incubation with $20 \mathrm{~mm}$ phosphate. The average length of the superstructure correlates positively with the previously published glutaminase activity levels (5). GAC is the most active isozyme and forms the longest polymers (top left panel), followed by KGA (top right panel), with lower activity and shorter structures, and lastly LGA, which is insensitive to phosphate and accordingly does not form filaments (bottom left panel). Unless otherwise specified, the scale bars represent $100 \mathrm{~nm}$.

sponsive to phosphate $\left(k_{\text {cat-app }} / K_{m \text {-app }}\right.$ of $0.6 \mathrm{~mm}^{-1} \cdot \mathrm{s}^{-1}$ at 20 $\mathrm{mM} \mathrm{P}_{\mathrm{i}}$ against $3.6 \mathrm{mM}^{-1} \cdot \mathrm{s}^{-1}$ for the wild type), which accordingly did not assemble into superoligomers (Fig. 1, F and $G$, right panel). The dimensions observed for particles of GAC.R322A in the presence of $20 \mathrm{~mm}_{\mathrm{i}}$ were very similar to those for the wild-type protein in the absence of $\mathrm{P}_{\mathrm{i}}(7 \pm 1$ and $8 \pm 2 \mathrm{~nm}$, for the short and long dimensions, respectively) (Fig. $1 D)$.

Superstructure among Glutaminase Isozymes-GAC is the most active of the three known mammalian glutaminase isozymes in response to inorganic phosphate (5). To further investigate the correlation between increased activity and larger oligomeric species, we observed the ability of KGA and LGA (also known as GLS2) to assemble into supratetrameric structures by TEM. Superstructure assembly was induced at 20 $\mathrm{mm}$ phosphate, stabilized by cross-linking with DSS, and subsequently gel filtration-purified. A tendency toward longer oligomers correlates well with the activity levels of the three isozymes. More specifically, GAC-the most active glutaminase at $20 \mathrm{mM} \mathrm{P}_{\mathrm{i}}$-forms the longest rod-shape oligomers (Fig. 2, top left panel), followed by KGA (Fig. 2, top right panel) and then LGA (Fig. 2, bottom left panel), which has been previously shown to be enzymatically insensitive to $P_{i}(5,22)$ and to not form the superstructure. The mean values for the shortest and longest dimensions of the particles are $16 \pm 2$ and $181 \pm 108$ $\mathrm{nm}$ for GAC, $14 \pm 3$ and $74 \pm 26 \mathrm{~nm}$ for KGA, and $9 \pm 2$ and $12 \pm 3 \mathrm{~nm}$ for LGA (Fig. 2, bottom right panel).

BPTES Disrupts GAC Superstructure-Counterintuitive to the current dimer to tetramer model of activation for GLS1, the inhibitor BPTES has been shown to lock GLS1 into an inactive yet tetrameric form (6). Interested in deciphering the mode of 


\section{Supratetrameric Oligomerization-dependent GAC Activation}
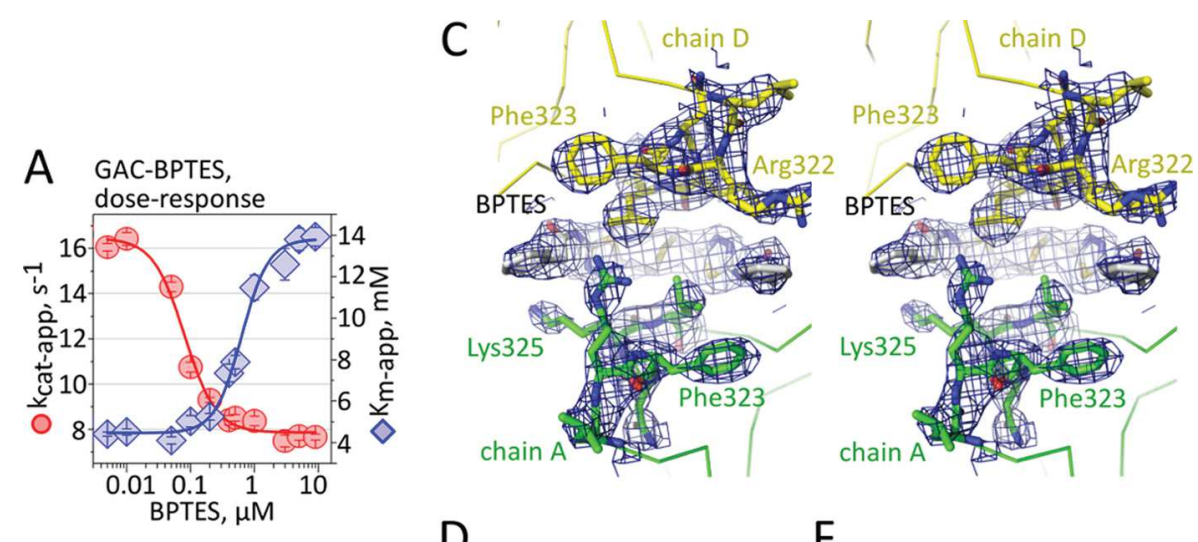

D
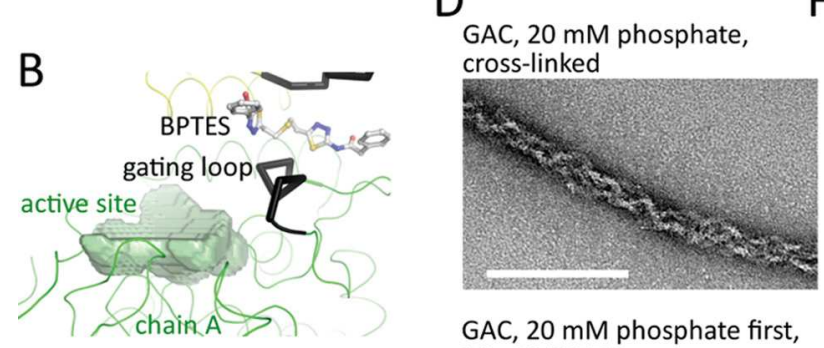

F

GAC.K325A, 0 mM phosphate, non-cross-linked

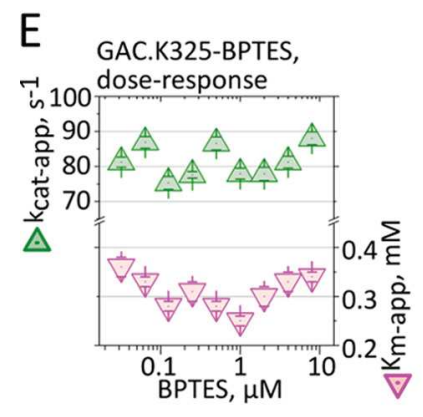

GAC, $20 \mathrm{mM}$ phosphate first, 30 MM BPTES, cross-linked
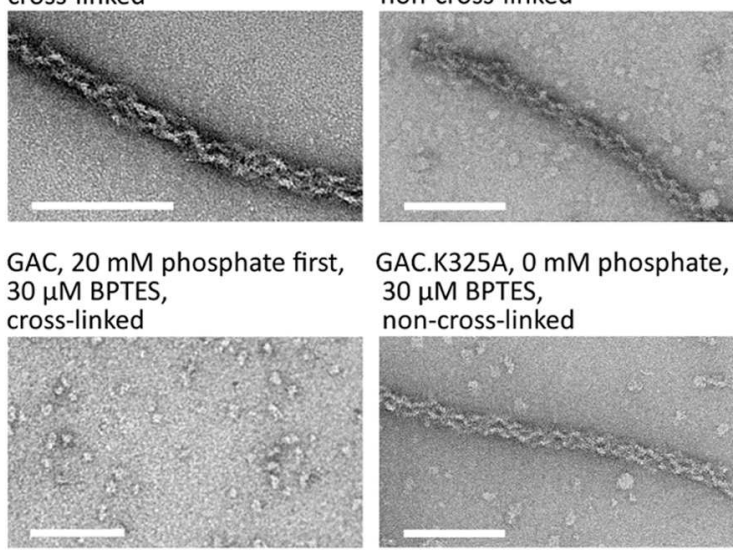

GAC.K325A, 0 mM phosphate, $30 \mu \mathrm{M}$ BPTES, non-cross-linked

GAC, $30 \mu \mathrm{M}$ BPTES first, 20 mM phosphate, cross-lilnked
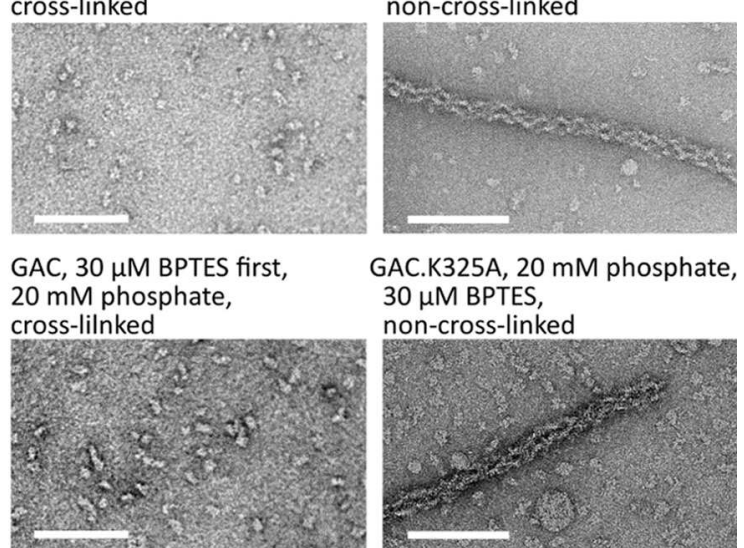

GAC.K325A, $20 \mathrm{mM}$ phosphate, $30 \mu \mathrm{M}$ BPTES, non-cross-linked

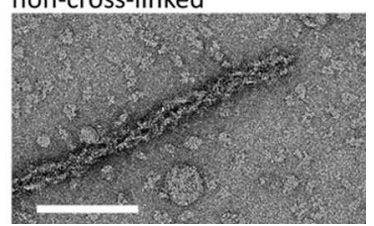

FIGURE 3. BTPES inhibits GAC superstructure formation. $A$, dose-response profile of BPTES inhibition on GAC, assayed in the presence of 20 mM phosphate, showing two complementary effects on the apparent turnover rates and the Michaelis constant of the enzyme. $B$, BPTES traps the gating loop (black ribbons) in a rigid open conformation relative to the catalytic pocket of GAC (delimited by a green surface). $C$, stereographic view of a Fourier $2 F_{\text {obs }}-F_{\text {calc }}$ map (at $1 \sigma$ ) confirming the proposed conformation in the refined crystallographic model. $D$, TEM analysis of the effects of BPTES on the formation of GAC superstructure. The filament formation is hindered regardless of whether BPTES is added to the protein solution prior to (middle panel) or after (bottom panel) incubation with $20 \mathrm{~mm}$ phosphate. $E$ and $F$, conversely, GAC.K325A is catalytically insensitive to BPTES treatment (E), and this inhibitor is also incapable of disrupting the non-cross-linked GAC.K325A filaments $(F)$.

inhibition by which BPTES exerts its effect and its relationship with the formation of the superstructure, we determined a detailed BPTES dose-response curve for GAC in the presence of $20 \mathrm{~mm}$ Pi. This phosphate concentration was chosen because it is closer to the physiological one under hypoxic conditions (23) and substantially stimulates GAC catalytic activity (5). We observed a strong inhibitory effect on GAC, where nanomolar levels of BPTES affected the maximum catalysis rate, $k_{\text {cat-app' }}$ without changing the $K_{m \text {-app }}$ for glutamine (Fig. $3 A$ ), a clear indication of an allosteric noncompetitive inhibitor as already published by others $(6,7)$. Curiously, beyond 200 nм BPTES, a secondary effect is observed and the inhibitor started affecting also the $K_{m \text {-app }}$ (a 3-fold increase compared with the absence of BPTES), redefining BPTES as a mixed mode inhibitor (Fig. $3 A$ ). By fitting an error bar-weighted logistic sigmoid function to explain the decrease in the turnover rates of the enzyme caused by the increased presence of inhibitor, we obtained an $\mathrm{IC}_{50}$ of $80.4 \pm 7.2 \mathrm{~nm}$ for BPTES, which is consistent with the value provided by DeLaBarre et al. (7). Upper and lower limits for the catalytic rates are 16.4 and $7.9 \mathrm{~s}^{-1}$, respectively, with a Hill slope of $1.7 \pm 0.2\left(R^{2}=0.99\right)$, indicating cooperative binding (Fig. $3 A)$. Concerning the effect on $K_{m \text {-app }}$, the upper and lower limits are 4.6 and $13.8 \mathrm{mM}$, with an $\mathrm{IC}_{50}$ of $629 \pm 61 \mathrm{nM}$ for BPTES (Hill slope of $2.0 \pm 0.3, R^{2}=0.99$ ).

Concomitant with the studies above, we have also determined the crystal structure of mouse GAC in complex with BPTES (2.77 $\AA$ resolution, $R_{\text {factor }}$ of $25.3 \%$, and $R_{\text {free }}$ of $29.5 \%$; Table 1). Although similar to previously reported BPTESbound glutaminase structures, with two inhibitor molecules tightly accommodated at the tetramer interface and average backbone root mean square deviations of 0.44 and $0.56 \AA$ when superposed to Protein Data Bank structures 3UO9 and 3VOZ, 


\section{Supratetrameric Oligomerization-dependent GAC Activation}

TABLE 1

X-ray crystallography data collection parameters and structure refinement statistics of BPTES-bound mouse glutaminase C (Protein Data Bank code 4jkt)

The data for the outer shell are shown in parentheses. LNLS, Laboratório Nacional de Luz Síncrotron.

\begin{tabular}{|c|c|}
\hline \multicolumn{2}{|l|}{ Data collection } \\
\hline Beamline & D03B-MX1 at LNLS, Brazil \\
\hline Wavelength $(\AA)$ & 1.608 \\
\hline Space group & $\mathrm{P} 2_{1} 2_{1} 2_{1}$ \\
\hline Cell parameters $a, b, c(\AA)$ & $100.7,140.2,180.9$ \\
\hline Resolution range $(\AA)$ & $38.4-2.77(2.82-2.77)$ \\
\hline Unique reflections & $63,967(2,039)$ \\
\hline Multiplicity & $3.3(2.6)$ \\
\hline$R_{\text {p.i.m. }}(\%)$ & $11.0(24.0)$ \\
\hline Completeness (\%) & $95.5(46.2)$ \\
\hline$<I / \sigma(I)>$ & $4.5(2.8)$ \\
\hline Average mosaicity $\left({ }^{\circ}\right)$ & 1.0 \\
\hline B-factor Wilson Plot $\left(\AA^{2}\right)$ & 40.5 \\
\hline Monomers/AU & 4 \\
\hline Solvent content (\%) & 59.2 \\
\hline Matthews coefficient $\left(\mathrm{A}^{3} / \mathrm{Da}\right)$ & 3.01 \\
\hline \multicolumn{2}{|l|}{ Model refinement } \\
\hline Resolution range $(\AA)$ & $20.0-2.77$ \\
\hline Reflections (cross-validation) & $63,892(5,952)$ \\
\hline$R_{\text {factor }} / R_{\text {free }}(\%)$ & $25.3 / 29.5$ \\
\hline \multicolumn{2}{|l|}{ Average $B$-factor $\left(\AA^{2}\right)$} \\
\hline Main chain (no. of residues) & $32.9 / 3.4(1,563)$ \\
\hline Side chain (no. of residues) & $32.8 / 4.3(1,362)$ \\
\hline BPTES (no. of molecules) & $44.1 / 9.2(2)$ \\
\hline Solvent (no. of molecules) & $24.4 / 5.9(265)$ \\
\hline \multirow{2}{*}{\multicolumn{2}{|c|}{$\begin{array}{l}\text { Root mean square deviation } \\
\text { from standard geometry }\end{array}$}} \\
\hline & \\
\hline Bond length $(\AA)$ & 0.003 \\
\hline Bond angles $\left({ }^{\circ}\right)$ & 0.783 \\
\hline \multicolumn{2}{|l|}{ Ramachandran plot } \\
\hline Most favored (\%) & 94.5 \\
\hline Allowed (\%) & 4.8 \\
\hline Outlier (\%) & 0.7 \\
\hline
\end{tabular}

respectively $(7,8)$, our crystal form presents a key unique feature. As a consequence of the binding of the small molecule to the tetramer interface, the main chain of the gating loop-consistently poorly ordered across all the GAC crystallographic models-is in a stable open conformation in all four monomers. This is due especially to the contacts made mainly between BPTES and Lys ${ }^{325}$, and consequently the loop assumes the conformation of a one-turn helix (Fig. 3, $B$ and $C$ ). Fifteen hydrogen bonds are made between a dimer of GAC and one BPTES molecule (data not shown). Eleven residues from each monomer share the interface with BPTES, occluding a combined total area of $620 \AA^{2}$. Of the total solvent-accessible surface of BPTES $\left(788 \AA^{2}\right.$ ), 80\% is buried upon interaction with the enzyme.

Next, we assessed the effects of BPTES on the formation of GAC superoligomers. TEM and size exclusion chromatography of wild-type GAC samples prepared in the presence of phosphate and the inhibitor and subsequently cross-linked showed that regardless of whether BPTES is added prior or after protein incubation in $20 \mathrm{~mm}$ phosphate; complete disruption of the superstructure is observed at a concentration of 30 $\mu \mathrm{M}$ of BPTES (Fig. 3D). The distribution of the disrupted particles on the grids is similar to the wild-type protein in the absence of phosphate and BPTES, as shown in Fig. $1 A$ (top panel).

Finally, we observed that the mutant GAC.K325A, besides being hyperactive, is also catalytically insensitive to BPTES as determined by a dose-response curve (Fig. 3E). Accordingly, BPTES is incapable of disrupting non-cross-linked GAC.K325A oligomers, assembled in the presence or absence of phosphate (Fig. 3F).

Superstructure Characterization-Because of its heterogeneous length distribution, the GAC superstructure is intrinsically inappropriate for crystallization. However, by combining TEM, chemical cross-linking followed by MS analysis, and computational biology, we provide a low resolution model for the superstructure. The extended particles tend to adsorb to the microscopy grids in a very limited number of orientations. However, the best micrographs show a combination of translational and rotational symmetry elements lying parallel to the polymer, thus yielding a helical symmetry along its longitudinal axis. Detailed analysis of low pass filtered images provided its geometrical attributes. The observed spiral polymer, under particular staining conditions, resembles a right-handed doublestranded helix, with a rise per turn of $\sim 53 \pm 2 \mathrm{~nm}$, a strand inclination of $25^{\circ}$, and an average width for a single strand of $6.6 \pm 0.7 \mathrm{~nm}$ (Fig. $4 A$ ).

Simultaneously, size exclusion-purified cross-linked polymers-as well as GAC cross-linked in the tetrameric form (used as a control)-were digested with trypsin, and the resulting peptides were subjected to liquid chromatography coupled to tandem mass spectrometry. The cross-linked peptides were modeled based on the crystal structure of the tetramer, using a spacer arm length for DSS of $\sim 11.4 \AA$ as a restraint for maximum distance between the side chain amine groups of linked lysines. This was necessary to distinguish between the different possible inter- and intramolecular cross-links. Unique linkages were only observed in the tetramer samples (spectra shown in Fig. $4 B$ ), between residues Lys ${ }^{181}$ and Lys ${ }^{207}$ (both located in the outer $\mathrm{N}$-terminal portion of the same monomer), Lys ${ }^{202}$ and Lys $^{578}$ (the latter located at the C terminus), and Lys ${ }^{403}$ and Lys $^{512}$ (both within the glutaminase domains, flanking the active site of two different monomers) as depicted in Fig. 4C. The observation that these DSS-mediated links are unable to form upon polymerization suggests occlusion of their respective surfaces from the solvent when in the superstructure form. One lysine residue from each of the cross-linked pairs was then substituted by an oppositely charged glutamate residue, and the individually mutated proteins (termed GAC.K202E, GAC.K207E, and GAC.K512E) were tested for superoligomerdependent glutaminase activity. Both N-terminal mutants, GAC.K202E and GAC.K207E, resulted in enzymes with enhanced activity (Fig. 4D, left panel), which coherently formed bigger particles, when compared with wild-type GAC (Fig. 4D, right panel). Conversely, the glutaminase domain mutant GAC.K512E fully lost the phosphate-dependent enzymatic capability and, accordingly, the ability to self-assemble into the superoligomers. The three point mutations reinforce the need for superoligomer formation for protein enzymatic activity and, most importantly, further show the importance of regions unrelated to and distant from the catalytic pocket for superoligomer formation and enzyme activation.

In the original biochemical characterizations of recombinant GLS1, Kenny et al. (12) demonstrated the importance of the GLS1 N-terminal portion for enzyme activity by generating a truncated, catalytically inactive, recombinant construct. Nevertheless, subsequent crystal structures of GAC clearly showed 


\section{Supratetrameric Oligomerization-dependent GAC Activation}

A

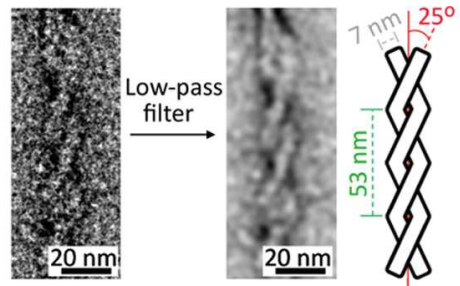

B
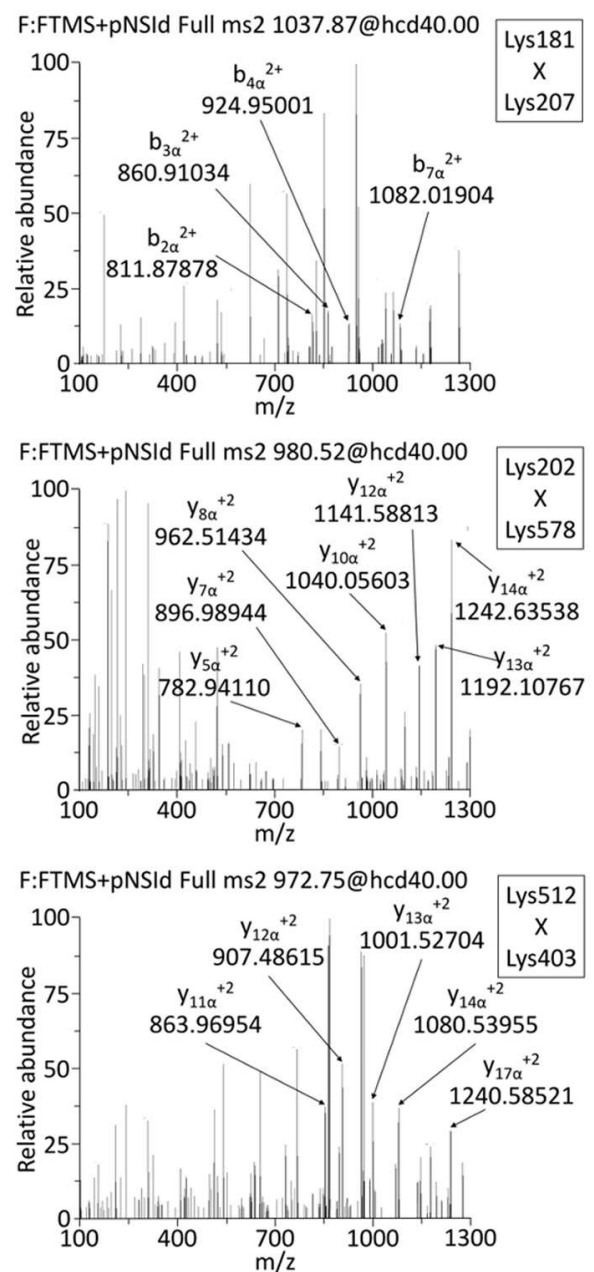
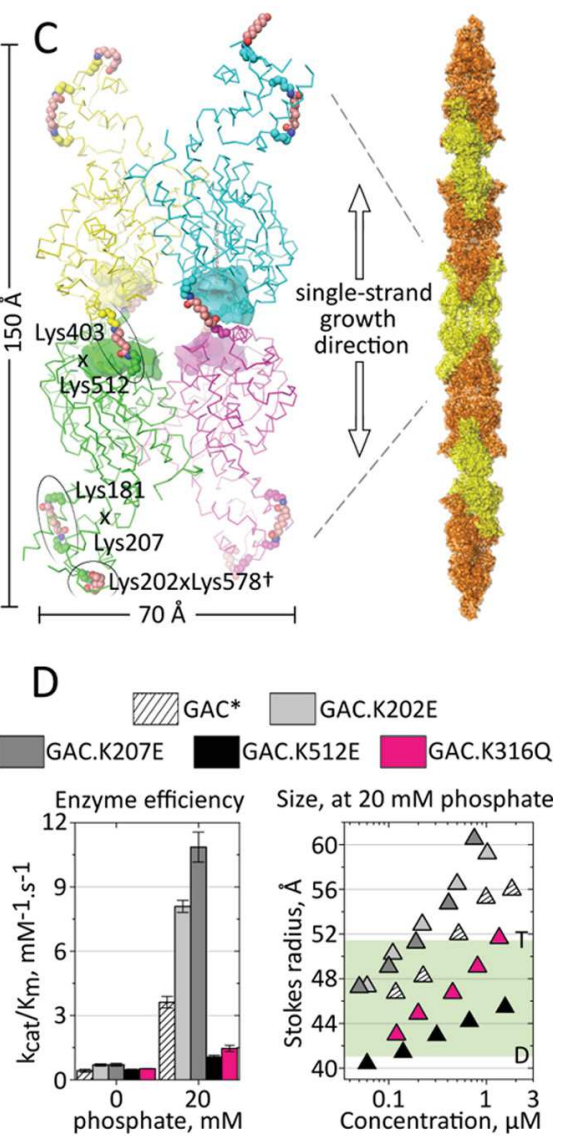

$\mathrm{E}$
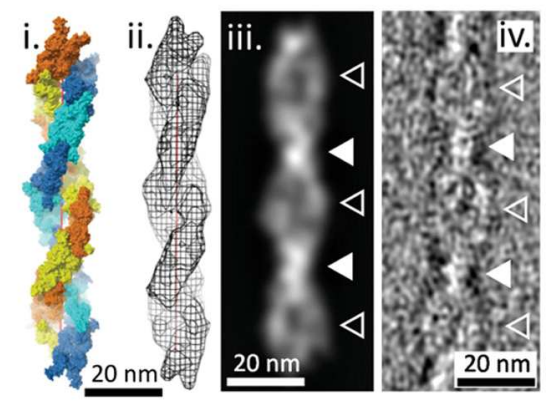

FIGURE 4. A model of GAC superoligomer assembly. $A$, the removal of high frequencies (strongly associated with noise) from the TEM micrographs highlights the right-handed double-strand nature of the superstructure, allowing the determination of its geometric features. $B$, cross-linked MS/MS spectra were manually validated for $b$ and $y$ ion series of the $\alpha$ and $\beta$ chains of cross-linked peptides (between residues Lys ${ }^{181}$ and Lys ${ }^{207}$, Lys ${ }^{202}$ and Lys ${ }^{578}$, and Lys ${ }^{403}$ and Lys ${ }^{512}$. The ions are indicated by arrows with corresponding $\mathrm{m} / \mathrm{z}$ value. $C$, relative position of DSS-linked lysine pairs in the tetramer, as identified by MS. The boundaries of the active sites are delimited by solid surfaces. + , Lys ${ }^{578}$ is not modeled in the crystal structure. The proposed single strand growth direction is across the longest axis of the tetramer, via an end to end interaction between pairs of $\mathrm{N}$-terminal domains. Alternating orange and yellow colors facilitate the identification of the tetramers along the single strand. $D$, one lysine residue from each cross-linked pair was individually substituted by a glutamate and assayed for enzymatic activity (left panel) and superstructure formation (right panel). The N-terminal region mutants (GAC.K202E and GAC.K207E) enhanced both effects. On the other hand, GAC.K512E, within the glutaminase domain, generated a nonfunctional protein, similarly to the acetylation mimetic GAC.K316Q. The green region delimits the expected Stokes radii between GAC dimers $(D)$ and tetramers $(T)$, calculated based on the crystal structure dimensions. The asterisk indicates a previously published result for wild-type GAC (5). $E$, the double strand was manually modeled (panel $i$ ), using two entwined copies of the single strand from $C$ and following the geometric restrictions of $A$. In panel ii, the calculated Fourier $F_{\text {calc }}$ map (with amplitudes and phases from the double strand model)—limited to $35 \AA \AA$ maximum resolution-is two-dimensionally projected, and the end result is shown in panel iii. All features are comparable to those observed in panel iv, concerning the presence of alternating high density narrow regions (indicated by filled triangles) and low density broad, disc-like regions (indicated by open triangles).

no direct participation of residues belonging to the $\mathrm{N}$-terminal portion in catalysis or even their requirement for the proper folding or stabilization of the active site. Based on the dimensions observed in the GAC crystal structures, the average width of $66 \AA$ for a single strand indicates that polymerization occurs along the longest axis of the tetramer, thus suggesting an end to end interaction via $\mathrm{N}$-terminal regions. The growth is thus consistently favored in one direction and may occur indefinitely, because N-terminal sticky ends will always be available at both termini (computational docking of several tetramers simulating strand growth is shown in Fig. 4C, left panel). Therefore, because activity is dependent on filament assembly and the N-ter- 


\section{Supratetrameric Oligomerization-dependent GAC Activation}

minal portion is key for such, we provide a plausible explanation for the findings of Kenny et al. (12).

Next, to generate a model for the double-stranded filamentous structure, the coordinate files of two single strands were manually coiled around each other, using the helical parameters as restraints (Fig. 4E). The Gaussian low pass filter applied to the reference micrographs remove spatial frequencies higher than $0.028 \AA^{-1}$, thus resulting in an estimated $35 \AA$ resolution in real space. According to its overall dimensions, both lengthwise and angle-wise, the estimated minimum repeating unit (one full helical turn) is composed of seven tetramers in each of the entwined strands. The intrinsic 2 -fold dihedral symmetry of the tetramer (5) renders it unnecessary to determine whether the double-stranded helix is of a parallel or anti-parallel nature because each strand is apolar. To validate the model against the experimental data, an $F_{\text {calc }}$ Fourier electron density map was generated by the program FFT (24) (to $35 \AA$ maximum resolution), using structure factors calculated from the three-dimensional double-stranded coordinate file and subsequently theoretically projected in two-dimensions using the electron microscopy software Imagic (25). The end result is shown in the right panel of Fig. $4 E$ and presents features that are fully comparable to those observed in the representative micrographs of Fig. $1 E$ (bottom panel), especially concerning the presence of an alternating pattern of narrow, compact regions of high density interspersed with broad, disc-like regions of low density.

Lastly, Lys ${ }^{311}$ in human GLS1 glutaminases was found to be a target for in vivo acetylation by high resolution mass spectrometry analysis (13). This lysine residue belongs to the glutaminase domain and is located on the opposite surface in relation to the catalytic pocket and the gating loop, with no direct participation in the active site. To evaluate the effects of this reversible, post-translational modification over superstructure formation and therefore protein activation, we have generated a point mutant in the equivalent residue of the mouse protein (GAC.K316Q), replacing it with a glutamine residue, so as to mimic the noncharged nature of acetylated lysine. Interestingly, the newly mutated protein was characterized as less sensitive to the activator phosphate with the concomitant lowered tendency to assemble into the superoligomers, keeping the protein in sizes compatible with only tetramers and dimers (Fig. $4 D$, left and right panels).

GAC Superstructure in Cell Model-To further demonstrate the importance of the superstructure assembly for GAC enzymatic activation, we generated stable clones of the MDA-MB 231 breast cancer cell line expressing either the human V5-tagged wild-type or the GAC.K325A mutant proteins, as well as cells transformed with a mock plasmid. Although in humans the appropriate numbering should be GAC.K320A (NCBI reference sequence AAD47056.1), we have decided to keep GAC.K325A (mouse GAC) for the sake of coherence throughout the paper. Cell clones were selected to present comparable levels of ectopic V5-tagged mRNA and protein while not presenting abnormally higher levels of ectopic expression (Fig. 5, $A$ and $B$ ). Proper mitochondrial localization of the ectopic protein was confirmed by cell fractionation and immunoblotting (data not shown). Two distinct phenotypes were readily observed for the GAC.K325A-V5 cells, when com-
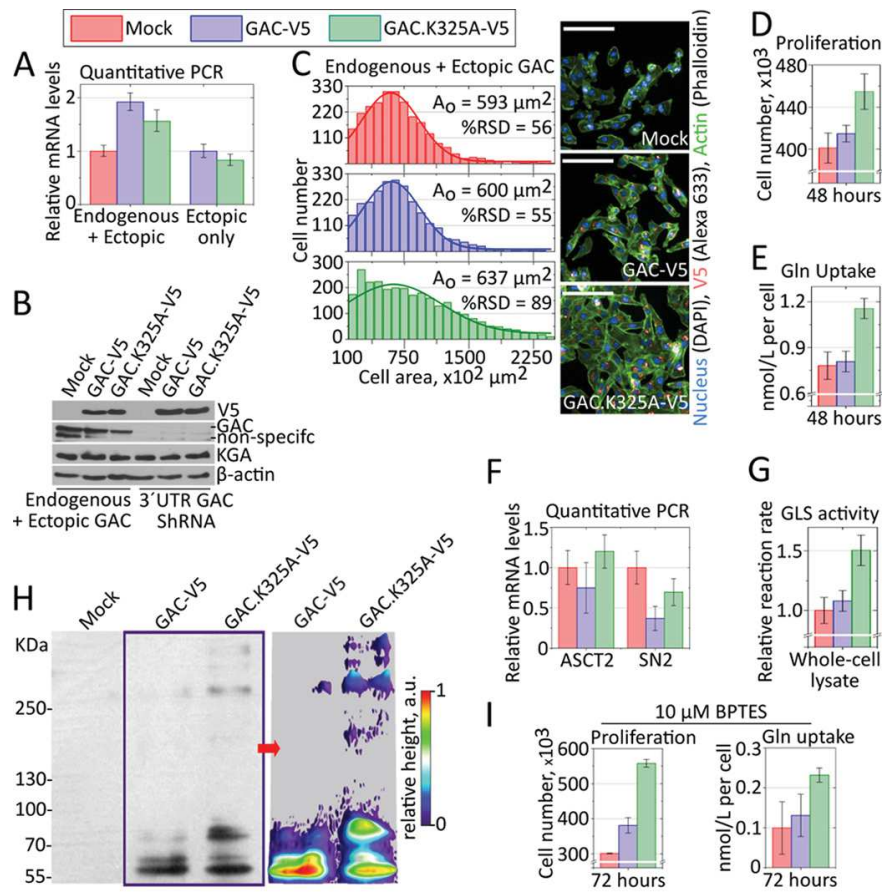

E Gln Uptake

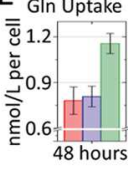

$\mathrm{F}$

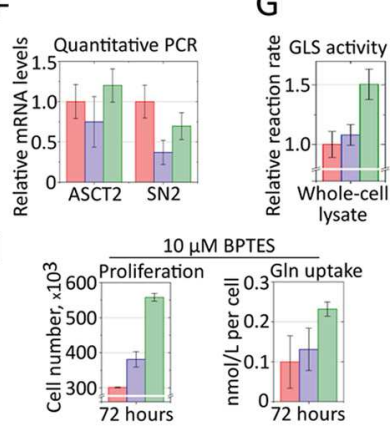

G

J

Endogenous GAC knock-down
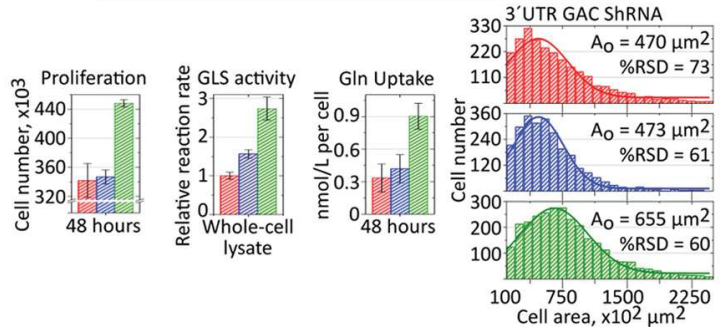

FIGURE 5. GAC superstructure in cell models. $A$ and $B$, endogenous and V5-tagged ectopic proteins expressed to similar levels. $C-E$, a stable MDA-MB 231 clone selected after GAC.K325A-V5 transfection presented larger and more heterogeneous cell area $(C)$, proliferated more $(D)$, and consumed more glutamine from the culture media $(E)$, all compared with cells bearing the V5-tagged wild-type protein or a mock plasmid. $F$, relative mRNA levels of ASCT2 and SN2 glutamine transporters, as defined by quantitative PCR using rRNA $18 \mathrm{~S}$ as a housekeeping gene, showing that the GAC.K325A-V5 cells do not overexpress these transporters. $G$, glutaminase activity from whole cell lysate, in the presence of $20 \mathrm{~mm}$ phosphate, showing consistently higher turnover rates for the GAC.K325A-V5 samples, against the physiological glutamine levels in tumors. $H$, left panel, step gradient SDS-PAGE (3-15\%) followed by immunoblotting (anti-V5) of UV-induced cross-linked intracellular protein with incorporated photo-reactive amino acids, showing the tendency of the GAC.K325A-V5 to form higher molecular weight superstructures within the cells. The UV-induced cross-linking was performed in living, intact cells in culture. Right panel, densitometry was performed in conditions of nonsaturated signal, using ImageJ, to evidence the differential cross-linking of bigger species for GAC.K325A-V5. I, similar to what was observed for the recombinant protein, cells expressing the fiber-prone hyperactive GAC.K325 mutant (GAC.K325A-V5) were less sensitive to BPTES treatment, still proliferating more (left panel) and consuming more glutamine (right panel) than BPTEStreated counterparts. $J$, the knockdown of endogenous GAC favored the enhancing of the phenotypic differences observed above, better highlighting the outcome from GAC.K325A-V5 expression.

pared with the GAC-V5 and mock counterparts. First, GAC.K325A-V5 cells were, on average, much larger and heterogeneous in size, as based on the measurement of cell area (Fig. 5C). More specifically, whereas the GAC-V5 and the mock transformed cells presented similar, normally distributed cell areas, peaking at 593 and $600 \mu \mathrm{m}^{2}$, respectively, the GAC.K325A-V5 population was much more heterogeneous in 


\section{Supratetrameric Oligomerization-dependent GAC Activation}

size (relative standard deviation of $89 \%$ ) and still $\sim 7 \%$ larger, averaging $637 \mu \mathrm{m}^{2}$. Second, the mutant-transformed cells proliferated $\sim 10 \%$ more than the wild-type and mock transfected cells, as determined by the quantification of cell numbers (Fig. $5 D)$. The average diameter of unattached (trypsinized) cells was also assessed to account for the effects of cell spreading on the area measurements. GAC.K325A-V5 cells presented the largest diameters, averaging at $13.3 \mu \mathrm{m}(n=178)$, when compared with the wild-type GAC-V5 $(10.9 \mu \mathrm{m}, n=151)$ and mock cells $(10.6 \mu \mathrm{m}, n=174)$ (data not shown).

Next, glutamine uptake from the culture medium was evaluated after $48 \mathrm{~h}$ of plating. We found that although the glutamine consumption levels for the GAC and the mock transformed cells was deemed indistinguishable $(0.78 \pm 0.09$ and $0.81 \pm 0.07$ $\mathrm{nmol} /$ liter per cell, respectively), GAC.K325A-V5 cells consumed $40 \%$ more glutamine (1.16 $\pm 0.07 \mathrm{nmol} /$ liter per cell), as shown in Fig. 5E. In parallel, we showed that GAC.K325-V5 cells do not express more of the glutamine transporters ASCT2 and SN2 (Fig. 5F). To account for the observed increase in glutamine consumption, we assessed the glutaminase activity in a physiological level of L-glutamine $(7.5 \mathrm{~mm})$ and observed that the reaction rates for the GAC.K325A-V5 cells are $40-50 \%$ higher when compared with the other two clones (Fig. 5G). Faster turnover rates were also consistently observed for the recombinant mutant protein, as shown in the first section.

To inspect for higher than tetramer oligomer formation within the living cells, cells were grown in the presence of photo-reactive amino acids and then exposed to UV light (at 365 $\mathrm{nm}$ ), followed by immunoblotting against the whole cell extract. The data clearly showed that GAC.K325A-V5 was cross-linked in cell into higher molecular weight species than GAC-V5 (Fig. 5H). Although the cross-linked species did not extend as far as those observed for the recombinant protein in vitro-likely because of the hetero-oligomerization between the V5-tagged mutant protein and endogenous wild-type GAC inside the mitochondria-the differential cross-linking pattern is evident. We have shown that the enzymatic activity of the recombinant mutant GAC.K325A is unaffected by BPTES treatment (Fig. 3E), which, accordingly, did not disrupt the superstructure (Fig. 3F). As a further confirmation that the superoligomer formation is important for the observed phenotypes, we treated cells with $10 \mu \mathrm{M}$ of BPTES. As expected, GAC.K325A-V5 cells still grew more and consumed higher amounts of glutamine than BPTES-treated control cells (Fig. 5I). BPTES treatment has drastically decreased the glutamine consumption on all the cell clones because it likely disrupted hetero-oligomers (formed by endogenous wild-type GAC and ectopic GAC.K325A-V5) and because it is also inhibits KGA (6). Despite this, the ectopic expression of GAC.K325A was able to improve the proliferation and growth phenotype of the cells.

Lastly, to exclude the possibility that the difference in cell proliferation and growth, as well as Gln uptake for the GAC.K325A-V5 cells were due to higher amounts of endogenous enzyme (in comparison to control cells), as well as to highlight the ectopic protein activity, we knocked down endogenous GAC by using a shRNA target to its mRNA 3 '-UTR (Fig. $5 B$ ). Not surprisingly, the previously observed phenotypic differences became enhanced. The mutant-transformed cells grew
$30 \%$ more and were $40 \%$ bigger, while consuming $\sim 2.2$ times more glutamine per cell, than the wild-type-expressing cells (Fig. 5J). Accordingly, the activity levels assessed from the whole cell extract in the presence of $7.5 \mathrm{~mm}$ L-glutamine were 75\% higher than the control assays (Fig. 5J). Overall, this collection of results directly demonstrated that the phenotypic differences above resulted from the presence of an ectopically expressed, hyperactive, and higher molecular weight prone protein GAC.K325-V5, which presented the same biochemical features and the intrinsic tendency to assemble into a superstructure as the recombinant mutant protein.

\section{DISCUSSION}

Previous biochemical studies have established that GLS1 glutaminases are mainly found as inactive dimers and that the presence of phosphate correlates with changes leading to tetramerization and enzyme activation $(26,27)$. We provide here novel information in that regard and show that the catalytic activation of the GLS1 glutaminases is directly linked to a fiber-like supratetrameric assembly, which correlates well with activation levels of the three glutaminase isozymes. The first observations of this phenomenon were provided $\sim 40$ years ago, using purified glutaminase from pig renal extract $(28,29)$. The formation of extended polymers was later used to purify the native enzyme by size exclusion, allowing its first biochemical and kinetic characterization (30), thus implying that our results are not an artifact of recombinantly expressed, truncated protein constructions, or even the chemically induced intermolecular cross-linking. Robinson et al. (6) have also documented larger oligomers for recombinant GLS1 in the presence of phosphate. The right-handed double-stranded molecular model that we propose here, when two-dimensionally projected using electron microscopy software, is not only in fully agreement with our experimental micrographs but also with the phosphate-borate induced form and the shadow casting reported by Olsen et al. (29) in 1973. Some of our micrographs suggest lateral association between two polymers, as seen, for instance in Figs. $1 E$ (top right and middle panels) and 2 (top left box), as well as those of the GAC.K325A mutant (Figs. $1 E$ and $3 F$ ). Regardless of these side by side associations, only the longitudinal growth seems to be connected to an increase in protein activity. Such a feature was also observed by Olsen et al. (29). Furthermore, it is also worth mentioning that with regard to the glutaminolytic pathway, polymerization is not exclusive to GLS1 glutaminases. Glutamic dehydrogenase from bovine liver has been shown to self-assemble into long multichain tubular structures under appropriate conditions (31). It is plausible then, that nonpathogenic polymer assembly may be a widespread process for the functioning of other metabolic enzymes.

Robinson et al. (6) first demonstrated biochemically that BPTES inhibits the GLS1 isoform (but not the liver-type isozyme, LGA/GLS2) by interfering with its phosphate-dependent allosteric activation and promoting the stabilization of the glutaminase into an inactive tetrameric form, later confirmed structurally $(7,8)$. Our collection of results indicates that BPTES inhibits GAC by trapping the gating loop at a rigid open conformation, which in turn prevents superoligomer formation. Although the tetramer- and phosphate-induced opening 


\section{Supratetrameric Oligomerization-dependent GAC Activation}

of this loop is necessary for enzyme activity, its intrinsic flexibility seems to play a major role on the enzymatic process. Indeed, we verified by molecular dynamics simulation on the tetramer that although phosphate binding to the catalytic site increases the gating loop flexibility, both L-glutamate (enzyme inhibition by L-glutamate has been reported for the kidney isoform of GLS1 (32)), and the presence of BPTES freezes the gating loop into a less mobile state (data not shown).

We observed from the kinetic studies with the GAC.K325A mutant that filament formation results in a drastic decrease in the Michaelis constant of the protein, over 100-fold, compared with the wild-type enzyme, in the absence of the activator $\mathrm{P}_{\mathrm{i}}$. A much greater accessibility of the active site to the substrate is suggested upon polymerization, as well as a key role of the gating loop in this process, a phenomenon that is fully reversed when $\mathrm{Arg}^{322}$ is replaced by alanine. Therefore, the present work unveils a new role for the gating loop, which besides regulating substrate accessibility to active site, also controls the reversible protein polymerization. Because of experimental limitations, which led to a low-resolution $35 \AA$ model, we are unable to describe the specific interactions that hold both the single and the double strands together and result in a fully activated enzyme. However, based on the most diverse effects generated mainly by the individual point mutations, it is plausible to suggest that shape complementarity is the driving force for selfassembly and can only be fully achieved after specific surface charges are enhanced or neutralized, an outcome easily attainable in the presence of a polyanion such as the phosphate ion. This is especially true in the case of the gating loop, where the replacement of two closely positioned, long and positively charged residues $\left(\mathrm{Arg}^{322}\right.$ and $\mathrm{Lys}{ }^{325}$ ) by alanine had antagonic effects with regards to protein self-assembly and activation. Concomitantly, major torsions in the relative positions of the monomers inside the tetramer-that are still experimentally undetected, because all GAC crystal structures available to date are virtually identical-may be required for gating loop-mediated superoligomer formation. The binding of BPTES, which shares an extensive area and a large number of hydrogen bonds at the tetramer interface and which also holds the loop into a rigid conformation (besides reducing the flexibility of the tetramer), would also prevent the gating loop from making these contacts. Such torsions in the tetramer cannot be predicted from our manually built model but could possibly be described in the future from higher resolution experimental data, such as by cryoelectron microscopy.

Recently, Katt et al. (9) described a potential binding site for the GAC inhibitor 968. In the proposed model, the small molecule docks inside a concave surface region formed at the dimerization interface of two GAC glutaminase domains. The 968 binding region lies very close to the $\mathrm{N}$-terminal portion of GAC, which is predicted here to be involved in the polymerization of the enzyme. The authors further showed that 968 is unable to bind and inhibit a previously phosphate-activated enzyme, which is in full consistency with what we present. Once GAC oligomers are assembled, because of the occlusion of the putative 968-binding site and the possible conformational changes in the $\mathrm{N}$-terminal portion of the enzyme required for self-assembly, they cannot be reversed by the addition of 968 , explaining its limited inhibitory capacity on an already activated enzyme. However, if 968 is bound to free tetramers, then such conformational changes cannot be subsequently achieved, stopping GAC activation via self-assembly. Given the complementary modes of inhibition for BPTES and 968, acting at different stages of enzyme assembly and polymerization, one might envision that a synergy in inhibition would result when both are administered to glutaminase sensitive transformed cell. To our knowledge, this still needs testing.

Our findings also suggest a role for the previously detected in vivo acetylation of Lys ${ }^{311}$ in human GLS1 glutaminases (13). We propose that this post-translational modification down-regulates the enzymatic levels by antagonizing the formation of the active superoligomers. Given that acetylation is a reversible post-translational modification, it is plausible to suppose that glutaminase superactivation may, at least in part, be regulated by acetyltransferases and deacetylases yet to be identified.

Finally, we need to state that we would not expect that micrometer-long GAC polymers assemble inside the mitochondria. Rather, a more tangible scenario might be the presence of shorter, heterogeneous filaments, similar to those observed in Fig. $1 A$ (lower panel). Nonetheless, direct visualization of such in the mitochondria has proven a difficult task. We showed that the superactive mutant GAC.K325A, intrinsically bound to self-assemble, was capable of providing growth and proliferation advantages to cells. However, a more important conclusion that can be drawn from these experiments is that an increased level of GAC in the mitochondria by itself is not sufficient to increase cell proliferation. The protein must be in the active form for such a phenotype to become evident. In cells, phosphate accumulation induced by hypoxia, for instance (23, 33), or even post-translational modifications, such as phosphorylation, could trigger polymerization, suggesting the possibility of distinct therapeutic opportunities for 968-like and BPTESlike inhibitors. Overall, our results reinforce the importance in focusing on the development of allosteric over active site-targeted inhibitors, glutamine analog inhibitors, when targeting GAC in tumors. This would result in preferred isoform-specific inhibitors, because LGA (GLS2), necessary for glutamine metabolism in the liver and brain, does not assemble into superoligomers, as well as avoiding the undesirable cross-inhibition of amidotransferases (21).

Acknowledgments-We thank the Laboratório Nacional de Biociências for access to its facilities (Laboratório de Purificação de Proteinas, Laboratório de Espectroscopia e Calorimetria, Laboratório de Espectrometria de Massas, Laboratório de Bioensaios, Laboratório de Vetores Virais, and Robolab); Laboratório Nacional de Nanotecnologia for access to Laboratório de Microscopia Eletrônica; and Laboratório Nacional de Luz Síncrotron for access to D03B-MX1 Beamline. We thank Dr. Alessandra Girasole for secretarial and technical support of Annelize Aragão and Romênia Domingues for helping with the MS analysis. We thank Dr. Richard C. Garratt (Instituto de Fisica de São Carlos, Universidade de São Paulo) for critical reading of the manuscript. 


\section{Supratetrameric Oligomerization-dependent GAC Activation}

\section{REFERENCES}

1. Gaglio, D., Metallo, C. M., Gameiro, P. A., Hiller, K., Danna, L. S., Balestrieri, C., Alberghina, L., Stephanopoulos, G., and Chiaradonna, F. (2011) Oncogenic K-Ras decouples glucose and glutamine metabolism to support cancer cell growth. Mol. Syst. Biol. 7, 523

2. Le, A., Lane, A. N., Hamaker, M., Bose, S., Gouw, A., Barbi, J., Tsukamoto, T., Rojas, C. J., Slusher, B. S., Zhang, H., Zimmerman, L. J., Liebler, D. C. Slebos, R. J., Lorkiewicz, P. K., Higashi, R. M., Fan, T. W., and Dang, C. V. (2012) Glucose-independent glutamine metabolism via TCA cycling for proliferation and survival in B cells. Cell Metab. 15, 110-121

3. Gao, P., Tchernyshyov, I., Chang, T. C., Lee, Y. S., Kita, K., Ochi, T., Zeller, K. I., De Marzo, A. M., Van Eyk, J. E., Mendell, J. T., and Dang C. V. (2009) c-Myc suppression of miR-23a/b enhances mitochondrial glutaminase expression and glutamine metabolism. Nature 458, 762-765

4. Wang, J. B., Erickson, J. W., Fuji, R., Ramachandran, S., Gao, P., Dinavahi, R., Wilson, K. F., Ambrosio, A. L., Dias, S. M., Dang, C. V., and Cerione, R. A. (2010) Targeting mitochondrial glutaminase activity inhibits oncogenic transformation. Cancer Cell 18, 207-219

5. Cassago, A., Ferreira, A. P., Ferreira, I. M., Fornezari, C., Gomes, E. R., Greene, K. S., Pereira, H. M., Garratt, R. C., Dias, S. M., and Ambrosio, A. L. (2012) Mitochondrial localization and structure-based phosphate activation mechanism of glutaminase $\mathrm{C}$ with implications for cancer metabolism. Proc. Natl. Acad. Sci. U.S.A. 109, 1092-1097

6. Robinson, M. M., McBryant, S. J., Tsukamoto, T., Rojas, C., Ferraris, D. V., Hamilton, S. K., Hansen, J. C., and Curthoys, N. P. (2007) Novel mechanism of inhibition of rat kidney-type glutaminase by bis-2-(5-phenylacetamido-1,2,4-thiadiazol-2-yl)ethyl sulfide (BPTES). Biochem. J. 406, 407-414

7. DeLaBarre, B., Gross, S., Fang, C., Gao, Y., Jha, A., Jiang, F., Song, J. J., Wei, W., and Hurov, J. B. (2011) Full-length human glutaminase in complex with an allosteric inhibitor. Biochemistry 50, 10764-10770

8. Thangavelu, K., Pan, C. Q., Karlberg, T., Balaji, G., Uttamchandani, M, Suresh, V., Schüler, H., Low, B. C., and Sivaraman, J. (2012) Structural basis for the allosteric inhibitory mechanism of human kidney-type glutaminase (KGA) and its regulation by Raf-Mek-Erk signaling in cancer cell metabolism. Proc. Natl. Acad. Sci. U.S.A. 109, 7705-7710

9. Katt, W. P., Ramachandran, S., Erickson, J. W., and Cerione, R. A. (2012) Dibenzophenanthridines as inhibitors of glutaminase $\mathrm{C}$ and cancer cell proliferation. Mol. Cancer Ther. 11, 1269-1278

10. Vander Heiden, M. G. (2011) Targeting cancer metabolism. A therapeutic window opens. Nat. Rev. Drug. Discov. 10, 671-684

11. Jones, N. P., and Schulze, A. (2012) Targeting cancer metabolism. Aiming at a tumour's sweet-spot. Drug Discov. Today 17, 232-241

12. Kenny, J., Bao, Y., Hamm, B., Taylor, L., Toth, A., Wagers, B., and Curthoys, N. P. (2003) Bacterial expression, purification, and characterization of rat kidney-type mitochondrial glutaminase. Protein Expr. Purif. 31, $140-148$

13. Choudhary, C., Kumar, C., Gnad, F., Nielsen, M. L., Rehman, M., Walther, T. C., Olsen, J. V., and Mann, M. (2009) Lysine acetylation targets proteins complexes and co-regulates major cellular functions. Science 325, $834-840$

14. Leslie, A. G. (1992) Recent changes to the MOSFLM package for processing film and image plate data. Joint CCP4 + ESF-EAMCB Newsletter on Protein Crystallography 26, 27-33

15. Evans, P. (2006) Scaling and assessment of data quality. Acta Crystallogr. D $62,72-82$

16. McCoy, A. J., Grosse-Kunstleve, R. W., Adams, P. D., Winn, M. D., Storoni, L. C., and Read, R. J. (2007) Phaser Crystallographic software. J. Appl. Crystallogr. 40, 658-674

17. Adams, P. D., Afonine, P. V., Bunkóczi, G., Chen, V. B., Davis, I. W., Echols,
N., Headd, J. J., Hung, L. W., Kapral, G. J., Grosse-Kunstleve, R. W., McCoy, A. J., Moriarty, N. W., Oeffner, R., Read, R. J., Richardson, D. C., Richardson, J. S., Terwilliger, T. C., and Zwart, P. H. (2010) PHENIX. A comprehensive Python-based system for macromolecular structure solution. Acta Crystallogr. D 66, 213-221

18. Emsley, P., Lohkamp, B., Scott, W. G., and Cowtan, K. (2010) Features and development of Coot. Acta Crystallogr. D 66, 486-501

19. Chen, V. B., Arendall, W. B., 3rd, Headd, J. J., Keedy, D. A., Immormino, R. M., Kapral, G. J., Murray, L. W., Richardson, J. S., and Richardson, D. C. (2010) MolProbity. All-atom structure validation for macromolecular crystallography. Acta Crystallogr. D 66, 12-21

20. Aragão, A. Z., Nogueira, M. L., Granato, D. C., Simabuco, F. M., Honorato, R. V., Hoffman, Z., Yokoo, S., Laurindo, F. R., Squina, F. M., Zeri, A. C., Oliveira, P. S., Sherman, N. E., and Paes Leme, A. F. (2012) Identification of novel interaction between ADAM17 (a disintegrin and metalloprotease 17) and thioredoxin-1. J. Biol. Chem. 287, 43071-43082

21. Yuneva, M. O., Fan, T. W., Allen, T. D., Higashi, R. M., Ferraris, D. V., Tsukamoto, T., Matés, J. M., Alonso, F. J., Wang, C., Seo, Y., Chen, X., and Bishop, J. M. (2012) The metabolic profile of tumors depends on both the responsible genetic lesion and tissue type. Cell Metab. 15, 157-170

22. Campos-Sandoval, J. A., López de la Oliva, A. R., Lobo, C., Segura, J. A., Matés, J. M., Alonso, F. J., and Márquez, J. (2007) Expression of functional human glutaminase in baculovirus system. Affinity purification, kinetic and molecular characterization. Int. J. Biochem. Cell Biol. 39, 765-773

23. Gorman, M. W., He, M. X., Hall, C. S., and Sparks, H. V. (1997) Inorganic phosphate as regulator of adenosine formation in isolated guinea pig hearts. Am. J. Physiol. 272, H913-H920

24. Read, R. J., and Schierbeek, A. J. (1988) A phased translation function. J. Appl. Crystallogr. 21, 490-495, DOI 10.1107/S002188988800562X

25. Van Heel, M., Portugal, R., Rohou, A., Linnemayr, C., Bebeacua, C., Schmidt, R., Grant, T. R., and Schatz, M. (2012) Four-dimensional Cryo Electron Microscopy at Quasi Atomic Resolution. IMAGIC 4D in International Tables for Crystallography Volume F. Crystallography of biological macromolecules (Arnold, E., Himmel, D. M., and Rossmann, M. G., eds) 2nd edition, pp. 624-628, John Wiley \& Sons, Inc., Hoboken, NJ

26. Godfrey, S., Kuhlenschmidt, T., Curthoys, P. (1977) Correlation between activation and dimer formation of rat renal phosphate dependent glutaminase. J. Biol. Chem. 252, 1927-1931

27. Morehouse, R. F., and Curthoys, N. P. (1981) Properties of rat renal phosphate-dependent glutaminase coupled to Sepharose. Evidence that dimerization is essential for activation. Biochem. J. 193, 709-716

28. Olsen, B. R., Svenneby, G., Kvamme, E., Tveit, B., and Eskeland, T. (1970) Formation and ultrastructure of enzymically active polymers of pig renal glutaminase. J. Mol. Biol. 52, 239-245

29. Olsen, B. R., Torgner, I. A., Christensen, T. B., and Kvamme, E. (1973) Ultrastructure of pig renal glutaminase. Evidence for conformational changes during polymer formation. J. Mol. Biol. 74, 239-251

30. Curthoys, N. P., Kuhlenschmidt, T., and Godfrey, S. S. (1976) Regulation of renal ammoniagenesis, purification and characterization of phosphatedependent glutaminase from rat kidney. Arch. Biochem. Biophys. 174, 82-89, DOI 10.1016/0003-9861(76)90326-X

31. Josephs, R., and Borisy, G. (1972) Self-assembly of glutamic dehydrogenase into ordered superstructures. Multichain tubes formed by association of single molecules. J. Mol. Biol. 65, 127-155

32. Curthoys, N. P., and Watford, M. (1995) Regulation of glutaminase activity and glutamine metabolism. Annu. Rev. Nutr. 15, 133-159

33. Fan, T. W., Higashi, R. M., and Macdonald, J. M. (1991) Emergence and recovery response of phosphate metabolites and intracellular $\mathrm{pH}$ in intact Mytilus edulis as examined in situ by in vivo ${ }^{31} \mathrm{P}-\mathrm{NMR}$. Biochim. Biophys. Acta 1092, 39-47 


\section{Allele-Specific Reprogramming of Cancer Metabolism by the Long Non-coding RNA CCAT2}

Roxana S. Redis, ${ }^{1}$ Luz E. Vela, ${ }^{2}$ Weiqin Lu, ${ }^{3,4}$ Juliana Ferreira de Oliveira, ${ }^{5}$ Cristina Ivan, ${ }^{6}$ Cristian Rodriguez-Aguayo, ${ }^{1}$ Douglas Adamoski, ${ }^{5}$ Barbara Pasculli, ${ }^{1}$ Ayumu Taguchi, ${ }^{3}$ Yunyun Chen, ${ }^{8}$ Agustin F. Fernandez, ${ }^{9}$ Luis Valledor, ${ }^{10}$ Katrien Van Roosbroeck, ${ }^{1}$ Samuel Chang, ${ }^{1}$ Maitri Shah, ${ }^{1}$ Garrett Kinnebrew, ${ }^{11}$ Leng Han, ${ }^{12}$ Yaser Atlasi, ${ }^{13,21}$ Lawrence H. Cheung, ${ }^{1}$ Gilbert Y. Huang, ${ }^{1}$ Paloma Monroig, ${ }^{1}$ Marc S. Ramirez, ${ }^{14}$ Tina Catela Ivkovic, $, 1,15$ Long Van, ${ }^{2}$ Hui Ling, ${ }^{1}$ Roberta Gafà, ${ }^{16}$ Sanja Kapitanovic, ${ }^{15}$ Giovanni Lanza, ${ }^{16}$ James A. Bankson, ${ }^{14}$ Peng Huang, ${ }^{3}$ Stephan Y. Lai, ${ }^{8}$ Robert C. Bast, ${ }^{1}$ Michael G. Rosenblum, ${ }^{1}$ Milan Radovich, ${ }^{11}$ Mircea Ivan, ${ }^{11}$ Geoffrey Bartholomeusz, ${ }^{1}$ Han Liang, ${ }^{17}$ Mario F. Fraga, ${ }^{18}$ William R. Widger, ${ }^{2}$ Samir Hanash, ${ }^{7}$ loana Berindan-Neagoe, ${ }^{1,19,20}$ Gabriel Lopez-Berestein, ${ }^{1,6}$ Andre L.B. Ambrosio, ${ }^{5}$ Sandra M. Gomes Dias, ${ }^{5}$ and George A. Calin $1,6, *$

1Department of Experimental Therapeutics, The University of Texas MD Anderson Cancer Center, Houston, TX 77030, USA ${ }^{2}$ Department of Biology \& Biochemistry, University of Houston, Houston, TX 77204, USA

${ }^{3}$ Department of Translational Molecular Pathology, The University of Texas MD Anderson Cancer Center, Houston, TX 77030, USA ${ }^{4}$ Department of Gastrointestinal Medical Oncology, The University of Texas MD Anderson Cancer Center, Houston, TX 77030, USA 5Laboratório Nacional de Biociências, Centro Nacional de Pesquisa em Energia e Materiais, Campinas 13083-100, Brazil ${ }^{6}$ Center for RNA Interference and Non-coding RNAs, The University of Texas MD Anderson Cancer Center, Houston, TX 77030, USA ${ }^{7}$ Department of Clinical Cancer Prevention, The University of Texas MD Anderson Cancer Center, Houston, TX 77030, USA ${ }^{8}$ Department of Head \& Neck Surgery, The University of Texas MD Anderson Cancer Center, Houston, TX 77030, USA

${ }^{9}$ Cancer Epigenetics Laboratory, Institute of Oncology of Asturias (IUOPA), HUCA, Universidad de Oviedo, Oviedo 33006, Spain ${ }^{10}$ Department of Organisms and Systems Biology, University of Oviedo, Ovideo 33006, Spain

${ }^{11}$ Department of Surgery, Medical and Molecular Genetics, Indiana University School of Medicine, Indianapolis, IN 46202, USA

${ }^{12}$ Department of Biochemistry and Molecular Biology, The University of Texas Health Science Center at Houston McGovern Medical School, Houston, TX 77030, USA

${ }^{13}$ Department of Pathology, Josephine Nefkens Institute, Erasmus Medical Center, Rotterdam 3015, the Netherlands

${ }^{14}$ Department of Imaging Physics, Division of Diagnostic Imaging, The University of Texas MD Anderson Cancer Center, Houston, TX 77030, USA

${ }^{15}$ Laboratory for Personalized Medicine, Division of Molecular Medicine, Ruder Boskovic Institute, Zagreb 10000, Croatia

${ }^{16}$ Department of Morphology, Surgery and Experimental Medicine, University of Ferrara, Ferrara 44121, Italy

${ }^{17}$ Department of Bioinformatics and Computational Biology, The University of Texas MD Anderson Cancer Center, Houston, TX 77030, USA

${ }^{18}$ Nanomaterials and Nanotechnology Research Center (CINN-CSIC), Asturias 33424, Spain

${ }^{19}$ Research Center for Functional Genomics, Biomedicine and Translational Medicine, University of Medicine and Pharmacy luliu Hatieganu, Cluj-Napoca 400012, Romania

20Department of Functional Genomics, The Oncology Institute, Cluj-Napoca 400015, Romania

${ }^{21}$ Present address: Radboud Institute for Molecular Life Sciences (RIMLS) Department of Molecular Biology, Nijmegen 6525, the Netherlands *Correspondence: gcalin@mdanderson.org

http://dx.doi.org/10.1016/j.molcel.2016.01.015

\section{SUMMARY}

Altered energy metabolism is a cancer hallmark as malignant cells tailor their metabolic pathways to meet their energy requirements. Glucose and glutamine are the major nutrients that fuel cellular metabolism, and the pathways utilizing these nutrients are often altered in cancer. Here, we show that the long ncRNA CCAT2, located at the 8q24 amplicon on cancer risk-associated rs6983267 SNP, regulates cancer metabolism in vitro and in vivo in an allelespecific manner by binding the Cleavage Factor I (CFIm) complex with distinct affinities for the two subunits (CFIm25 and CFIm68). The CCAT2 interaction with the CFIm complex fine-tunes the alternative splicing of Glutaminase (GLS) by selecting the poly(A) site in intron 14 of the precursor mRNA. These findings uncover a complex, allele-specific regulato- ry mechanism of cancer metabolism orchestrated by the two alleles of a long ncRNA.

\section{INTRODUCTION}

Long non-coding RNAs (IncRNAs) form the largest part of the mammalian non-coding transcriptome (Mercer et al., 2009) and are generally expressed in a developmental-, tissue-, or disease-stage-specific manner, which makes them attractive therapeutic targets (Ling et al., 2013a). Although the underlying molecular mechanisms are not yet entirely understood, IncRNAs control gene expression at various levels including chromatin modification and transcriptional and post-transcriptional processing (Wilusz et al., 2009).

The revival of Warburg's theory of cancer (Warburg et al., 1924), complemented with novel discoveries in the field, has promoted cellular metabolism as an essential molecular mechanism for driving malignant transformation and progression (Boroughs 
Please cite this article in press as: Redis et al., Allele-Specific Reprogramming of Cancer Metabolism by the Long Non-coding RNA CCAT2, Molecular Cell (2016), http://dx.doi.org/10.1016/j.molcel.2016.01.015

and DeBerardinis, 2015). Various studies have exposed the fine interplay between metabolic pathways orchestrated by proteincoding oncogenes and tumor suppressor genes (Chen and Russo, 2012) and, more recently, by ncRNAs (miRNAs and IncRNAs) (Gao et al., 2009; Yang et al., 2014). Glutamine, one of the essential nutrients, is deaminated by Glutaminase (GLS) to produce glutamate, which further serves as substrate for a variety of metabolic pathways (e.g., tricarboxylic cycle, TCA). Glutamine metabolism is modulated by MYC via miR-23a/b in prostate cancer and B cell lymphoma (Gao et al., 2009) and by NF-kB p65 subunit also through miR-23a downregulation in leukemic cells (Rathore et al., 2012; Wang et al., 2010b).

Colon Cancer-Associated Transcript 2 (CCAT2), a IncRNA that spans the highly conserved $8 \mathrm{q} 24$ region harboring the rs6983267 SNP (Ling et al., 2013b; Redis et al., 2013), is associated with increased risk for various types of cancer (Tomlinson et al., 2007; Tuupanen et al., 2009) and is specifically overexpressed in the microsatellite stable colorectal cancer (CRC MSS). The two alleles of the rs6983267 SNP present in the general population have been shown to render distinct risks of CRC; namely, the $\mathrm{G}$ allele was associated with greater predisposition to CRC than the T allele (Tomlinson et al., 2007). CCAT2 induces chromosomal instability and metastases (Ling et al., 2013b) and regulates the expression levels of MYC oncogene, known to coordinate multiple molecular pathways supporting cell proliferation, metastases and cancer metabolism (Carroll et al., 2015; Stine et al., 2015). However, it is not clear how the two alleles are specifically involved in the malignant process. In this study, we demonstrate that the IncRNA, CCAT2, modulates cellular energy metabolism in an allele-specific manner by interacting with the Cleavage Factor I (CFIm) complex to regulate the alternative splicing of GLS.

\section{RESULTS}

\section{CCAT2 Modulates Energy Metabolism in an Allele- Specific Manner In Vitro and In Vivo}

We observed an unexpected change in the color of the media of in vitro grown cells when modulating the expression of CCAT2 that suggested a possible shift in the energy metabolism consequent to CCAT2 expression. We tested this hypothesis by measuring metabolic parameters in HCT116 colon cancer cells that stably overexpress CCAT2 (OC1 and OC3) (Ling et al., 2013b) versus control cells and observed a significant and reproducible increase in glucose uptake, lactate secretion and oxygen consumption in the CCAT2-overexpressing clones (Figure 1A). These results were further confirmed in KM12SM cells with CCAT2 downregulated expression (Figure 1B). Moreover, we explored whether these metabolic changes were occurring in vivo as well by injecting HCT116 CCAT2-overexpressing cells and control cells subcutaneously into nude mice and subjecting them to hyperpolarized magnetic resonance imaging (HP-MRI). We detected a significant increase in the flux of hyperpolarized $\left[1-{ }^{13} \mathrm{C}\right]$ pyruvate to $\left[1-{ }^{13} \mathrm{C}\right]$ lactate for the xenograft tumors derived from the CCAT2-overexpressing cells compared to the tumors derived from control cells (Figures S1A and S1B), consistent with our in vitro findings. These findings confirm that CCAT2 alters metabolism, boosting glycolysis and cellular respiration.
The coexistence of increased glycolysis with increased respiration, in highly proliferative cells, translates into enhanced anaplerotic reactions that replenish the TCA cycle intermediates (Ward and Thompson, 2012). Since glutamine is the main source for replenishing the intermediates of the TCA cycle, we measured the intra- and extracellular glutamate concentration, as well as the glutamine uptake in HCT116 cells with CCAT2 overexpression and control cells. We found higher levels of both intra- and extracellular glutamate corresponding to higher levels of CCAT2 (Figures S1C and S1D), suggesting CCAT2 is boosting glutamine metabolism (glutaminolysis). Surprisingly, the glutamine uptake was not significantly different between the three clones (Figure S1D), implying the higher glutamate is not due to increased glutamine consumption. Therefore, we measured the enzymatic activity of GLS, the rate-limiting enzyme of glutaminolysis, in the whole lysate of the same cells and detected significantly higher activity in the cells with increased CCAT2 expression (Figure S1F). In addition, both metabolic pathways (glycolysis and glutaminolysis) have been shown to be regulated by many factors, including the MYC oncogene (Carroll et al., 2015; Stine et al., 2015), a target of CCAT2 by our previous report (Ling et al., 2013b).

We next explored whether the rs6983267 SNP influences these metabolic changes and assessed the glucose and glutamine uptake, oxygen consumption, lactate secretion, and intraand extracellular glutamate concentration in HCT116 stably overexpressing either the $\mathrm{G}$ or the T allele of CCAT2 and control HCT116 cells. Interestingly, we found on one hand higher glucose uptake and secreted glutamate in both $\mathrm{G}$ and $\mathrm{T}$ allele cells compared to control cells, while on the other hand we observed significant differences in lactate secretion, oxygen consumption, and intracellular glutamate production between the alleles (Figures $1 \mathrm{C}$ and S1E). Moreover, the glutamine consumption was not significantly different between the clones, similar to our previous results (Figure S1E). Consequently, we measured GLS enzymatic activity in these cells and observed that both CCAT2 alleles induced a remarkable increase in activity compared to control, but the cells overexpressing the $\mathrm{G}$ allele displayed a significantly higher enzymatic activity compared to the $T$ allele-overexpressing cells (Figure 1D). We also analyzed by mass spectroscopy the metabolites obtained from in vitro culturing of the HCT116 CCAT2 G or T allele and control cells and from in vivo xenografted tumors derived from subcutaneous injection of the same cells. We observed contrasting distribution patterns when performing partial least squares discriminant analysis (PLS-DA) for both the in vitro (Figure 1E) and in vivo analyses (Figure 1F), and similarly for the principal component analysis (PCA) (Figures S1G and S1H). We detected $85.04 \%$ (in vitro) and $59.55 \%$ (in vivo) of metabolic pathways upregulated by CCAT2 $\mathrm{G}$ allele compared to the T allele (Figure S1I, Table $\mathrm{S} 1 \mathrm{~B})$. We then compared the pathway analysis for both datasets and identified 40 common pathways for the $G$ allele and five common pathways for the T allele (Figure S1J). For these pathways, metabolic cluster distribution of differentially accumulated compounds revealed a significant overall enhancement of metabolic pathways related to glucose metabolism, TCA cycle, and glutamine metabolism for the $G$ allele cells compared to the T allele cells (Tables S1A and S1B). We evaluated the expression 
A

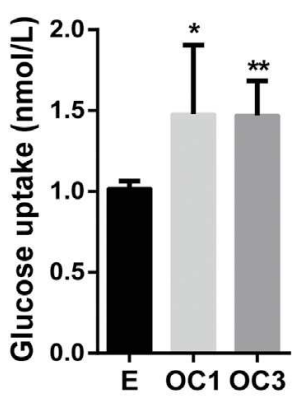

B

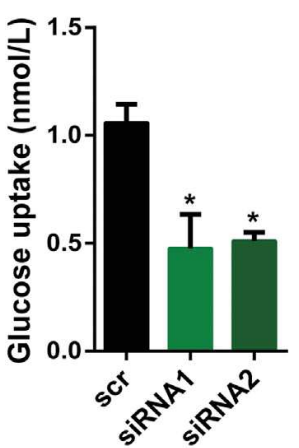

C

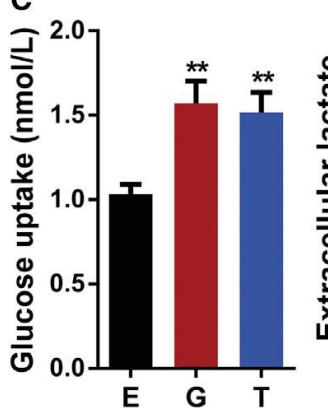

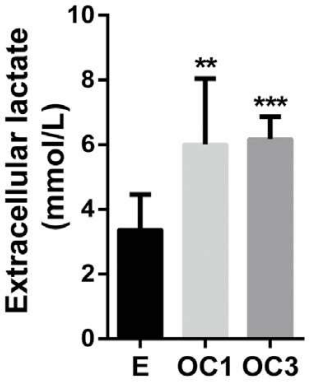

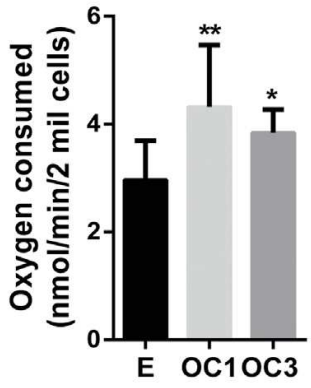

E SPLS-DA analysis of

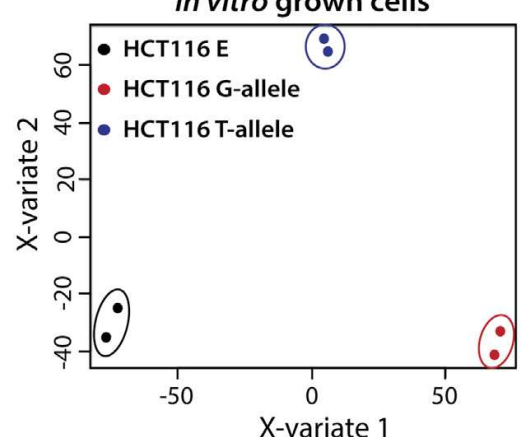

$\mathbf{F}$

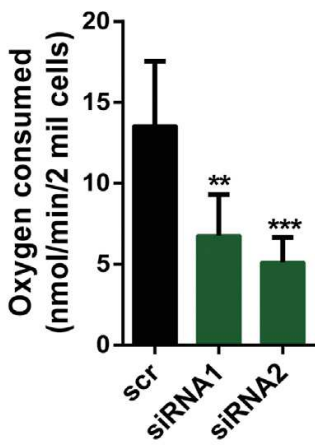

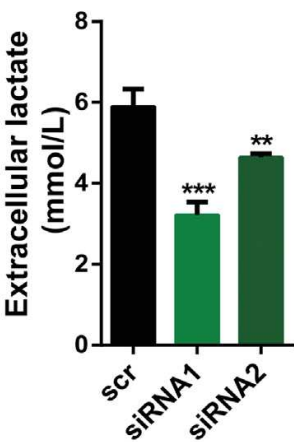

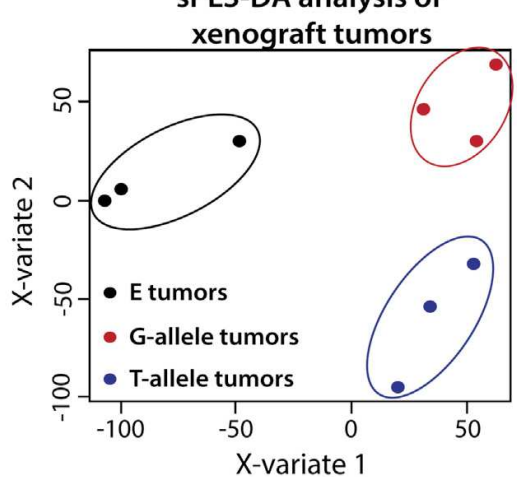

sPLS-DA analysis of

D
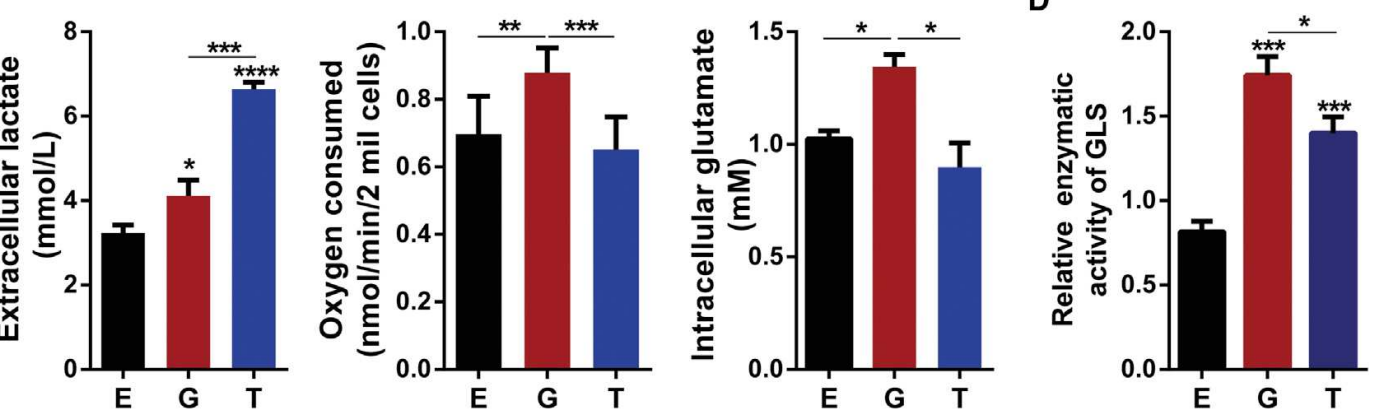

Figure 1. CCAT2 Regulates Cancer Metabolism In Vitro and In Vivo

(A) Glucose uptake, lactate production, and oxygen consumption assays in HCT116 stable clones (E: empty control vector; OC1 and OC3: CCAT2overexpressing, GG genotype).

(B) Glucose uptake, lactate production, and oxygen consumption assays in KM12SM cells with CCAT2 downregulation (GT genotype).

(C) Whole-cell lysate Glutaminase activity measured in HCT116 CCAT2-overexpressiong G or T allele and control cells.

(D) Partial least-squares discriminant analysis (sPLS-DA) of HCT116 cells stably overexpressing CCAT2 with either G or T alleles, and control cells (E, empty vector) in vitro allowed an adequate classification of the different cell lines according to its metabolome. sPLS-DA algorithm allows the classification of the samples based on the different abundances of each metabolite trying to find the maximum covariance between treatments and metabolome, in this way finding the most important metabolites for explaining the different effects of the treatments.

(E) Xenograft tumors derived from the same cell lines were also correctly classified by sPLS-DA analysis.

Results are presented as normalized mean values \pm SD. See also Figure S1 and Table S1.

of MYC between the HCT116 CCAT2 G and T allele cells but did not find impressive differences, consistent with our previous findings (Ling et al., 2013b) (Figure S2A). These results imply that in cells with high CCAT2 expression, MYC activates energy metabolism in a general fashion; however, the fine-tuning of distinct metabolic pathways may occur through MYC-independent, but SNP-dependent, mechanisms. We therefore decided to direct our efforts toward exploring the CCAT2 MYC-independent mechanism of regulation.

\section{CCAT2 Regulates the Expression of GLS Isoforms}

Our group has previously shown that CCAT2 induces chromosomal instability, a process highly reliant on the supply of nucleotides (Bester et al., 2011) and intimately linked to glutamine 
Please cite this article in press as: Redis et al., Allele-Specific Reprogramming of Cancer Metabolism by the Long Non-coding RNA CCAT2, Molecular Cell (2016), http://dx.doi.org/10.1016/j.molcel.2016.01.015

metabolism (Jeong et al., 2013). Further supported by the metabolic data, we directed our focus toward pathways metabolizing glutamine. We first assessed the protein expression of the two alternative splicing isoforms of GLS, KGA (glutaminase kidney isoform) and GAC (glutaminase isoform C) as a function of CCAT2. We used specific antibodies for each isoform (recognizing the distinct $\mathrm{C}$ termini) (Cassago et al., 2012) and/or a common antibody, recognizing the $\mathrm{N}$ terminus shared by the two isoforms, depending on the cell line. Although the two isoforms share the same active site, GAC has a higher catalytic activity than KGA and therefore may be more relevant for replenishing intermediates of the TCA cycle (Cassago et al., 2012; Le et al., 2012). While for GAC we observed an increase in protein expression in the HCT116 CCAT2-overexpressing cells with both antibodies, for KGA the protein expression presented an inconsistent variation with CCAT2 upregulation (Figures 2A, $\mathrm{S} 2 \mathrm{~B}$, and $\mathrm{S} 2 \mathrm{C}$ ). Analogously, the mRNA expression pattern for $G A C$ and $K G A$ reflected the protein expression (Figure 2B). Moreover, downregulation of CCAT2 in KM12SM cells reduced GAC protein expression with $34 \%$ and $26 \%$, respectively (Figures $2 \mathrm{C}, \mathrm{S} 2 \mathrm{D}$, and $\mathrm{S} 2 \mathrm{E}$ ), whereas KGA protein expression was either unaltered or slightly increased (Figures 2C, S2D, and S2E). Similar results were obtained when measuring the mRNA expression of the two isoforms in the same cellular model (Figure S2F). Interestingly, when we evaluated the expression of the two isoforms in the HCT116 cells overexpressing the CCAT2 $\mathrm{G}$ or $\mathrm{T}$ allele and control cells at both the mRNA and protein levels, we found unanimously higher expression of GAC when CCAT2 $\mathrm{G}$ allele is upregulated (Figures 2D and S2G-S2I). However, changes in the KGA mRNA expression pattern did not concur with the protein expression (Figures 2D and S2G-S2I). The discordance observed for the KGA isoform is probably due to the regulation by the MYC-miR-23 axis (Gao et al., 2009; additional data available from authors upon request). These results alluded to the idea that CCAT2 may preferentially induce the splicing of the GAC isoform. To determine this, we cloned the intron 14 of GLS precursor mRNA, known to encompass the alternative splicing site, in the RG6 bichromatic fluorescent reporter (Orengo et al., 2006). If the splicing machinery binds to the intron 14, it induces the splicing of a EGFP-tagged protein, which is the equivalent of GAC; otherwise, a dsREDtagged protein will be produced, which is the equivalent of KGA (Figure S2J). We transfected the HCT116 control and CCAT2-overexpressing cells with the fluorescent reporter and determined the ratio between the expression levels of EGFP and dsRED fluorescence using the VECTRA automated imaging system. Although the EGFP-tagged protein, GAC-equivalent, was predominant in all models, we observed a $50 \%$ significantly higher EGFP/dsRED ratio in the CCAT2-overexpressing cells, corresponding to $50 \%$ more alternative splicing events (Figure $2 \mathrm{E}$ ). Similar results were obtained when cells were analyzed by flow cytometry (Table S2). Moreover, when we compared the alternative splicing events occurring in the $\mathrm{G}$ and $\mathrm{T}$ alleles, using the RG6 reporter, we found significantly higher EGFP/dsRED ratio for the CCAT2 $\mathrm{G}$ allele compared to the CCAT2 T allele (Figure $2 \mathrm{~F}$ and Table S2). Altogether, these data demonstrate that the CCAT2 $\mathrm{G}$ allele is more efficient in boosting the alternative splicing of GAC isoform.

\section{CFIm25 Governs the Switch between GLS Splicing} Isoforms

To elucidate the underlying mechanism of CCAT2-induced regulation of the GLS alternative splicing, we introduced the MS2 tag (24 repeats) into vectors containing either the CCAT2 $\mathrm{G}$ allele or T allele, pulled down the proteins that bind CCAT2, and analyzed them by mass spectrometry (Yoon et al., 2012). Pathway analysis on the QIAGEN platform identified Cleavage and Polyadenylation of Pre-mRNA among the top pathways associated with the G allele (Figure S3A), with CFIm25, the small (25 kDa) subunit of CFIm encoded by the NUDT21 gene (Elkon et al., 2013; Yang et al., 2011), as the main protein correlated with the pathway. Notably, in the T allele pull down, both CFIm25 and the larger subunit $(68 \mathrm{kDa})$ of the CFIm complex, CFIm68 (encoded by the CPSF6 gene), were detected (CFIm68 was not detected in the $\mathrm{G}$ allele pull down); however, for CFIm25, the area under the peak had a 1.48 higher fold change in the $G$ allele compared to the $T$ allele (Figure S3B). We screened the GLS intron 14 for potential splicing and/or alternative polyadenylation (APA) sites using ASTRA (Alternative Splicing and TRanscription Archives database; http://dbarchive.biosciencedbc.jp/en/astra/ desc.html) (Nagasaki et al., 2006) and identified a type 2 (skipping exon) poly(A) site (Figure S3C) (Lutz and Moreira, 2011) and multiple conserved binding motifs (UGUA) for CFIm25, consistent with a previous report mapping two poly(A) motifs within the same intron of the GLS pre-mRNA (Tian et al., 2007). Considering that CFIm25 and the CFIm heterotetramer complex have been previously linked to alternative splicing (Millevoi et al., 2006; Zhou et al., 2002), we first downregulated NUDT21 and assessed the protein levels of GAC and KGA. We noticed a significant decrease in GAC protein expression in both cellular models and a clear increase in the KGA protein expression (Figure 3A). We also measured mRNA expression for the two isoforms and observed a significant reduction of the GAC/KGA mRNA ratio with NUDT21 knockdown (Figure 3B). In order to evaluate whether the switch in isoform expression is a consequence of CFIm25 binding to the UGUA sequences within intron 14 of GLS pre-mRNA, we designed antisense synthetic oligonucleotides (ASOs) to block the binding of the $25 \mathrm{kDa}$ subunit to these motifs (Figure $3 C$ ). Out of the four tested ASOs, we could identify two that were able to reverse the GAC to KGA protein expression ratio similar to the specific downregulation of NUDT21 in HCT116 OC1 cells (Figure $3 \mathrm{C}$ ). This result suggested that binding of CFIm25 to intron 14 is responsible for inducing the preferential expression of GAC. To further confirm the direct interaction of CFIm25 with GLS pre-mRNA and CCAT2, we immunoprecipitated the RNA bound to constituting proteins of the CFIm complex, CFIm25 and CFIm68, in HCT116 cells overexpressing either the G or T allele of CCAT2 and control cells, and measured the differences in RNA enrichment between the distinct pulldown lysates by real-time quantitative PCR (qRT-PCR) (Figures 3D-3F and S3D-S3F). We included two IncRNAs as controls: NEAT1 was chosen to be a positive control as it has been previously shown to interact with the CFIm complex (Naganuma et al., 2012), and GAS5 was chosen as negative control due to minimal sequence similarity with CCAT2 (Figure S3G). When assessing the fold enrichment of GLS and CCAT2, we detected, respectively, 5.77 and 13.6 times more RNA bound to CFIm25 in the 
A (kDa)

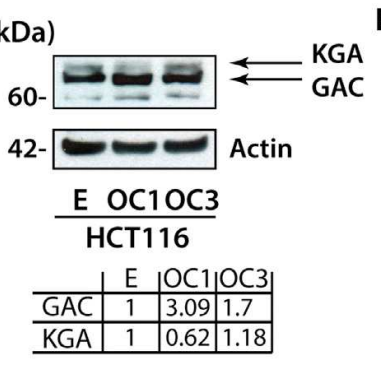

E

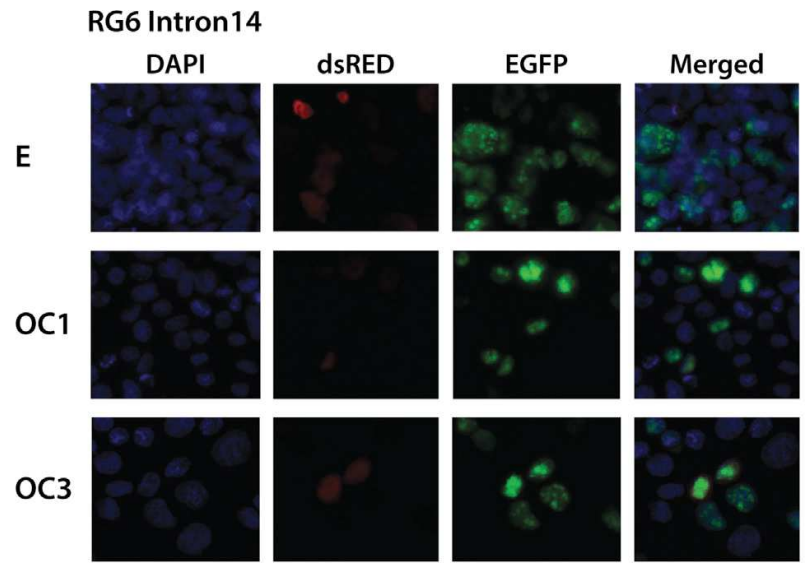

$\mathbf{F}$

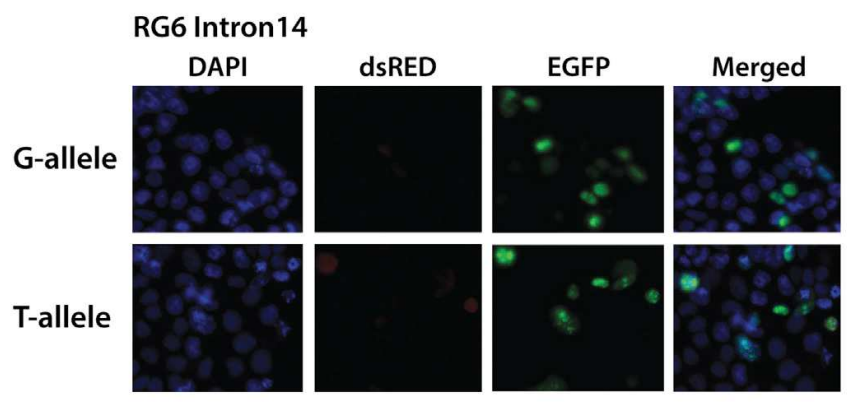

$\begin{array}{llll}\mathbf{C}_{(\mathbf{k D a})} & 1 & 0.93 & 1.14\end{array}$

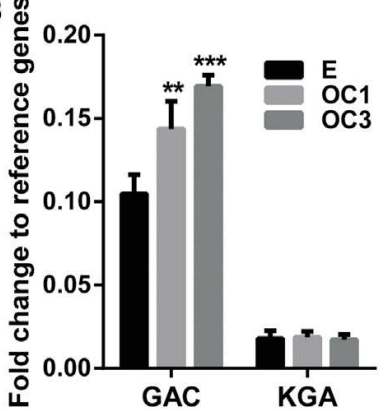

$\mathrm{D}_{(\mathrm{kDa})}$

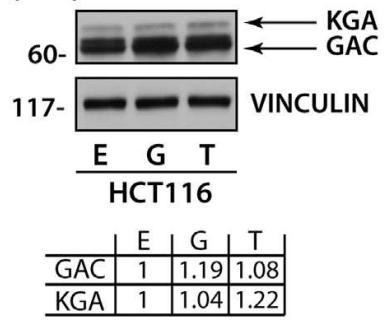

KM12SM

KGA

117

117

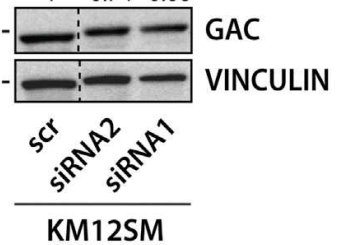

VINCULIN
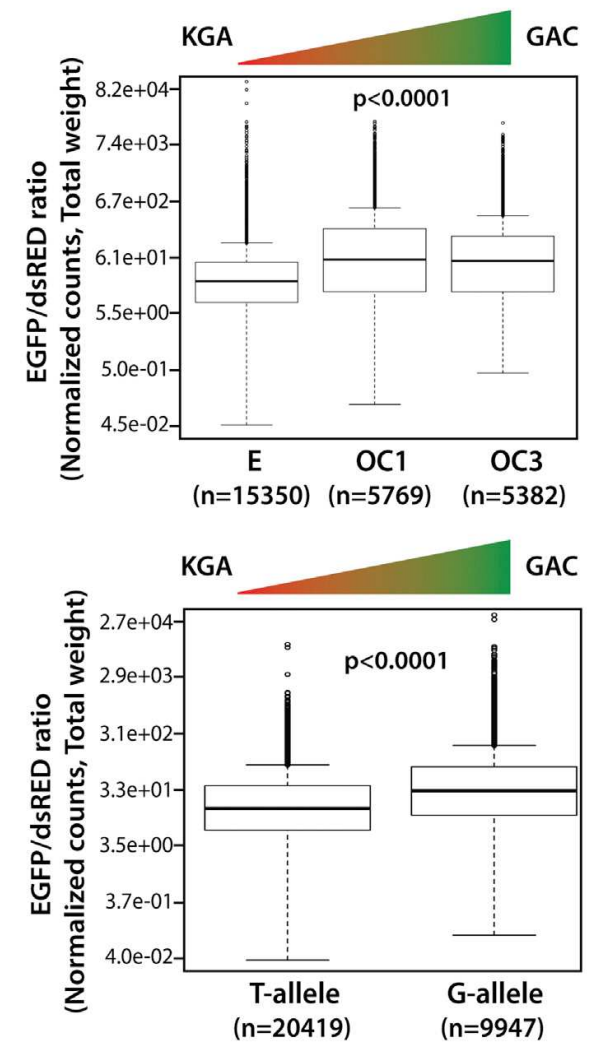

Figure 2. CCAT2 Induces the Preferential Splicing of GAC

(A) Western blot analysis of GAC, KGA in HCT116 CCAT2-overexpressing cells (OC1 and OC3) and control cells.

(B) qRT-PCR assessing the mRNA expression of GAC and KGA in HCT116 CCAT2-overexpressing cells (OC1 and OC3) and control cells.

(C) Western blot analysis of GAC, KGA in KM12SM cells with CCAT2 downregulation.

(D) Western blot analysis of GAC, KGA in HCT116 stably overexpressing CCAT2 G or T alleles and control cells.

(E) Fluorescence microscopy images of HCT116 stable clones (E, empty control vector; OC1 and OC3, CCAT2 overexpressing) transfected with the RG6 intron 14 vector and the analysis of the EGFP/dsRED ratio $(n=$ number of analyzed cells).

(F) Fluorescence microscopy images of HCT116 CCAT2 G allele and T allele transfected with the RG6 intron 14 vector and the analysis of the EGFP/dsRED ratio $(\mathrm{n}=$ number of analyzed cells).

Results are presented as normalized mean values \pm SD. See also Figure S2 and Table S2.

cells overexpressing CCAT2 G allele compared to control cells, while in the cells overexpressing CCAT2 T allele compared to control cells, the fold enrichment ratios were only about half (2.95 and 6.02, respectively) (Figure 3D). Moreover, comparing the fold enrichment in the G-overexpressing cells to the T-overexpressing cells, we observed roughly double fold enrichment in the G-overexpressing cells for both GLS and CCAT2 (1.95 and 2.26) (Figures $3 E$ and $3 F$ ). The positive control (NEAT1) presented 6.3-fold more RNA bound to CFIm25 in the cells overexpressing CCAT2 G allele compared to control cells and 2.79 -fold more RNA enrichment in the cells overexpressing CCAT2 T allele compared to control cells (Figures 3D and S3D). The negative 
A $(\mathrm{kDa})$
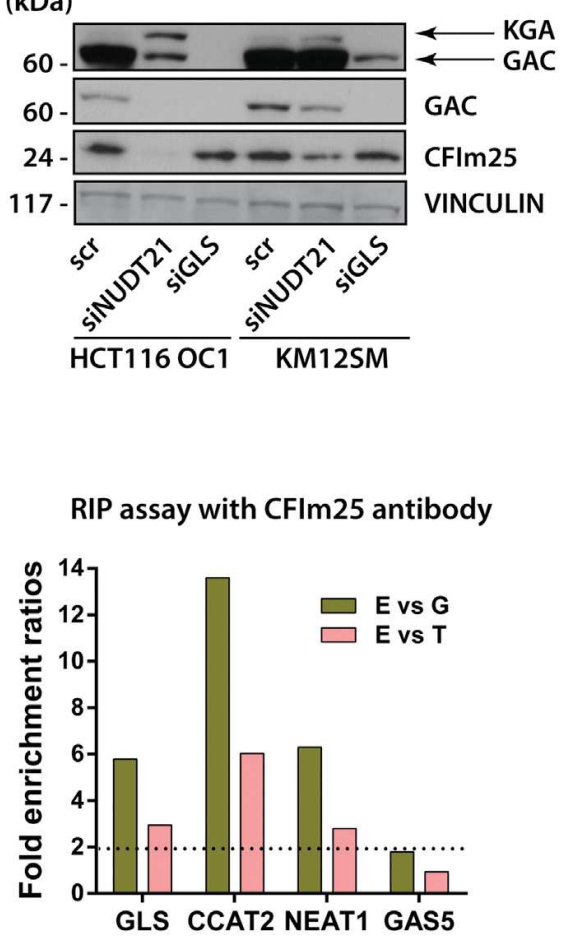

G

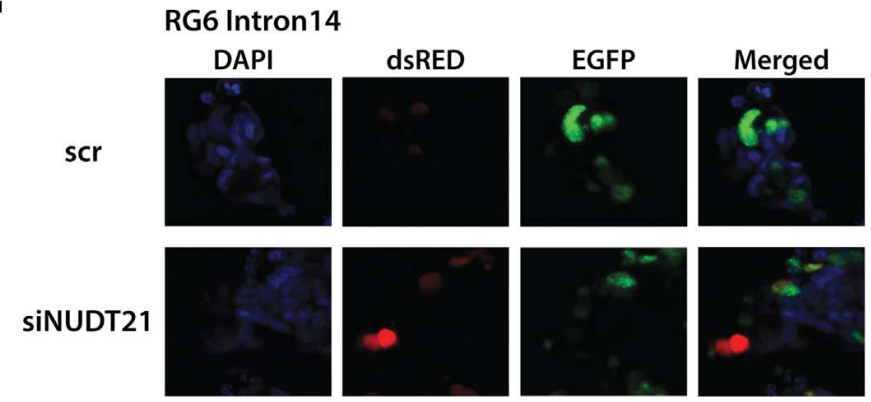

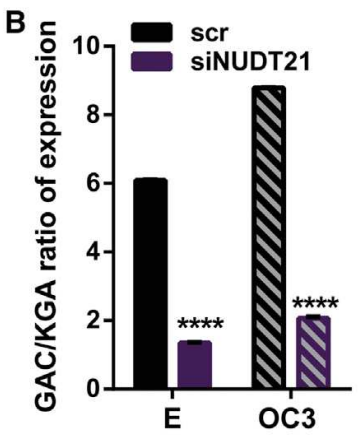

E

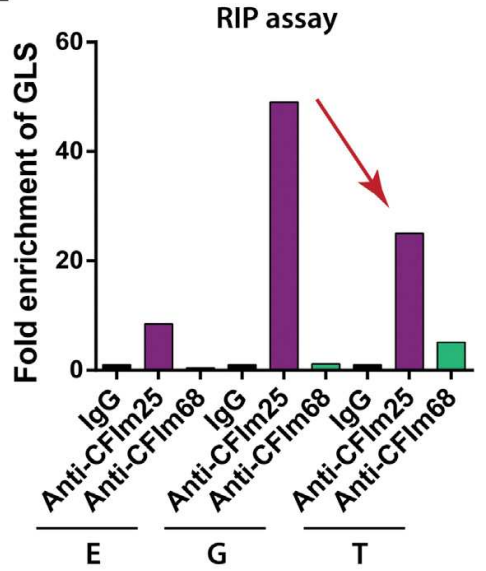

C $(\mathrm{kDa}) \quad 1 \quad 1.66 \quad 1.54$

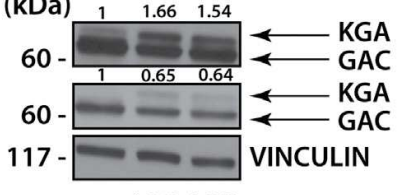

ctr ASO ASO

\#2 \#3

HCT116 OC1
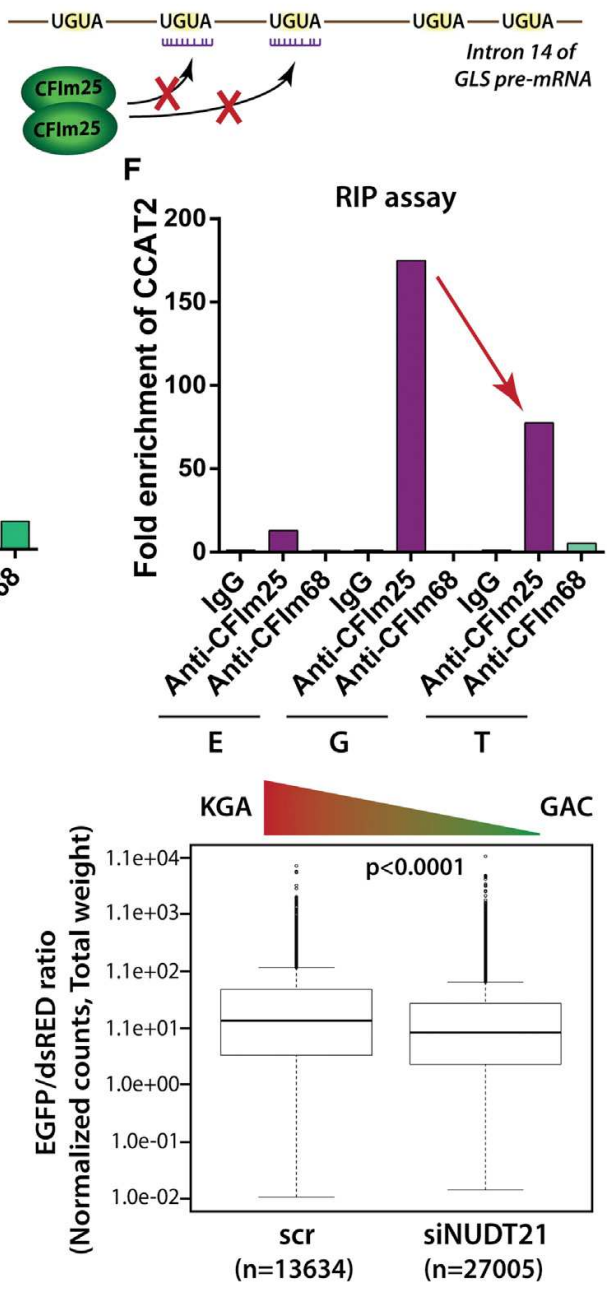

Figure 3. CFIm Protein Complex Binds GLS Pre-mRNA

(A) Western blot analysis of CFIm25, GAC, and KGA in HCT116 OC1 and KM12SM cells transiently transfected with siRNA for NUDT21, GLS (targeting the coding sequence shared by the two isoforms), and siRNA control.

(B) qRT-PCR assessing the GAC/KGA mRNA ratio in HCT116 CCAT2-overexpressing cells (OC1 and OC3) and control cells (E) with modulated CFIm25 expression.

(C) Western blot analysis of GAC and KGA in HCT116 OC1 cells with transient blockage of CFIm25 binding motifs (UGUA) by antisense oligonucleotides (ASOs). Schematic representation of the mechanism is presented below.

(D) qRT-PCR assessing the fold enrichment of GLS, CCAT2, NEAT1, and GAS5 RNA bound to CFIm25 protein (RNA immunoprecipitation). Data are presented as fold enrichment ratios between control HCT116 cells (E) and CCAT2-overexpressing G or T allele.

( $E$ and F) qRT-PCR assessing the fold enrichment of GLS mRNA (E) and CCAT2 (F) bound to CFIm25 and CFIm68 in HCT116 cells, CCAT2-overexpressing G or T alleles, and control cells (E).

(G) Fluorescence microscopy images of KM12SM cells transfected with siNUDT21 and scr, followed by transfection with the RG6 intron 14 vector, and the analysis of the EGFP/dsRED ratio ( $\mathrm{n}=$ number of analyzed cells).

Results are presented as normalized mean values \pm SD. See also Figure S3 and Table S2. 
control (GAS5) revealed only a 1.79-fold increase in the RNA bound to CFIm25 in the cells overexpressing CCAT2 G allele compared to control cells and no difference in RNA enrichment between the overexpressing CCAT2 T allele and control cells (Figures $3 \mathrm{D}$ and S3E). Thus, we concluded that, overall, in the cells overexpressing CCAT2, there is an augmentation of interaction between CFIm25 and GLS and CCAT2, with the highest levels in the G-overexpressing cells. The low binding of the RNAs to the CFIm68 was not surprising, as the main function of the protein is merely to enhance RNA binding and facilitate RNA looping, while the $25 \mathrm{kDa}$ subunit has the leading role in binding the RNA via the UGUA elements (Yang et al., 2011) (Figures 3E, 3F, S3D, and S3E). Nonetheless, for our RNAs of interest, we observed an increase in enrichment in the $T$ allele overexpressing cells compared to the $\mathrm{G}$ allele overexpressing and control cells, suggesting the secondary structure of CCAT2 T allele may ease the interaction between the $68 \mathrm{kDa}$ subunit and RNA molecules. In addition, we confirmed these results by end-point PCR in both the same cellular model and the KM12SM cell line, with a GT-heterozygous genotype (Figures S4A and S4B). As a further validation, we expressed the RG6 bichromatic fluorescent reporter with the intron 14 in KM12SM cells with knockdown of NUDT21. We assessed, by both VECTRA and FACS, the ratio of EGFP to dsRED and found a significantly lower (28\%) EGFP/dsRED ratio in the cells with NUDT21 downregulation, corresponding to fewer splicing events and consequently lower expression of the GAC equivalent (Figure 3G and Table S2).

\section{Alternative Splicing of GLS Is Associated with the Interaction between CCAT2 and the CFIm Complex} We next aimed to investigate in more detail the mechanism leading to the difference in binding affinity of CFIm25 and CFIm68 to the distinct CCAT2 alleles. We first scanned the CCAT2 RNA sequence and identified two CFIm25 binding motifs surrounding the rs6983267, one upstream and the other downstream of the SNP. We performed secondary structure predictions using the RNAfold Webserver (http://rna.tbi.univie.ac.at/ cgi-bin/RNAfold.cgi) and noticed major local structural changes induced near the putative upstream CFIm25 binding sequence, by the single nucleotide variation, especially among the $\mathrm{G}$ and $T$ alleles (Figure S4C). Such changes may plausibly translate into distinct tertiary folds that could in principle explain the binding of the $\mathrm{G}$ and $\mathrm{T}$ alleles with different affinities. To further validate our results and evaluate the contribution of a single nucleotide to the structural changes and binding affinity, we mutated the SNP into an A or C (nucleotides never detected in the human population) and also deleted the 7 nucleotide region encompassing the SNP, which has been reported to have enhancer activity (Tuupanen et al., 2009). We repeated the RNA pull-down assay using different vectors containing the MS2 tags (CCAT2-G, -T, -A, -C, and DEL) and analyzed by western blot the proteins bound to RNAs. When CFIm25 antibody was hybridized on the blot, we detected a strong band of approximately $64 \mathrm{kDa}$ unique to the $\mathrm{G}$ allele (band corresponds to the CFIm25 dimer; Figure 4A). When CFIm68 antibody was hybridized on the blot, we distinguished bands of approximately $68 \mathrm{kDa}$ for both the T allele and the allele with the deleted region
(Figure 4A). This implied that the T allele preferentially binds the $68 \mathrm{kDa}$ subunit, but not in the region of the SNP. Notably, neither of the two mutated CCAT2 alleles (A and C) interacted with the CFIm complex, and interestingly, both present secondary structures different from the $\mathrm{G}$ and T alleles (Figure $\mathrm{S} 4 \mathrm{C}$ ).

Additional evidence for the direct interaction between the CCAT2 $\mathrm{G}$ and $\mathrm{T}$ alleles with the CFIm complex was provided by a $\mathrm{His}_{6}$-tag pull-down assay using heterologously expressed CFIm68:CFIm25 complex (His ${ }_{6}$-tagged CFIm68 subunit; Figure 4B) incubated with in vitro synthesized RNAs. We detected strong affinity of the CFIm complex for the CCAT2 G allele, followed by moderate binding of the CCAT2 T allele. We also identified in the pull down the $600 \mathrm{nt}$ long region of the GLS pre-mRNA intron 14, containing one type 2 poly(A) site, with affinities for the protein complex corresponding to the two alleles (Figure 4B). This suggested that the intron 14 may also interact with CCAT2. To test this, we added a biotin tag to in vitro transcribed CCAT2 RNAs, combined them with the intron 14 fragment and/or CFIm complex, and pulled down the complex with Streptavidin beads. We confirmed not only that the CCAT2 G allele preferentially binds CFIm25, but also that CCAT2 interacts with the intron 14 fragment in a SNP-independent fashion (Figures $4 \mathrm{C}$ and S4D). To ensure the specificity of the interaction, we repeated the biotin RNA pull-down assay to include the biotinylated CCAT2 $\mathrm{C}$ allele as a negative control. We also added the whole intron 14, previously used for the RG6 splicing assay, to determine if CCAT2 can interact with the entire region. We prepared mixes of CCAT2 (G, T, and C) and the CFIm complex with and without the intron 14 fragment to evaluate how it impacts the interaction between CCAT2 and CFIm complex. We discovered that in the presence of the intron 14, CCAT2 $\mathrm{G}$ and $T$ alleles displayed increased binding affinity to the CFIm complex, compared to the $\mathrm{C}$ allele (Figures 4D and S4E and Table S3). The $G$ and $T$ alleles presented a remarkable specificity for the CFIm25 dimer in the presence of the intron 14 (both the smaller fragment and the whole intron) with enhanced binding to the $\mathrm{G}$ allele (Figure S4E and Table S3), supporting the hypothesis that the secondary structure of CCAT2 influences the interaction with the protein complex. In the absence of the intron, although the specificity of the interaction with the CFIm25 dimer is partly retained, it appeared to be revoked in the case of CFIm complex (Figures 4D and S4E and Table S3). We confirmed that CCAT2 $\mathrm{G}$ and T alleles can bind the whole intron 14 as well and aligned the CCAT2 genomic sequence with GLS genomic sequence to determine the extent of the interaction (Figure S4F). We observed multiple short fragments (13-18 nt) of sequence complementarity spanning the entire GLS sequence, present in both introns and exons (Figure S5A). For additional validation, we performed the $\mathrm{His}_{6}$-tag pull-down assay using the $\mathrm{G}, \mathrm{T}$, and $\mathrm{C}$ alleles in the presence and absence of the whole intron 14. As expected, when the intron was included in the mix, we could detect only CCAT2 $\mathrm{G}$ and T alleles in the pull-down lysates (Figure S4G).

Furthermore, the same mixes of CCAT2 RNA (G/T), CFIm protein complex, and intron 14 RNA were prepared, as well as solutions of individual components, and subjected to atomic force microscopy (AFM) for visualizing the formation of the RNA:protein:RNA quaternary complex (Lyubchenko et al., 2011) (Figures 
A

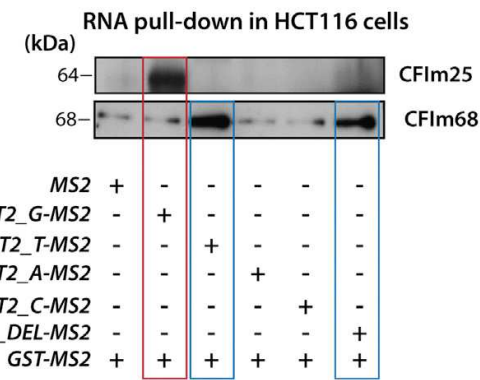

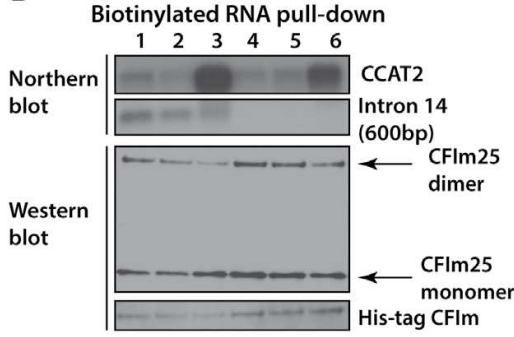

1: biotinylated CCAT2 G + CFIm complex + Intron 14 (600 bp) 2: biotinylated CCAT2 T + CFIm complex + Intron $14(600 \mathrm{bp})$ 3: biotinylated CCAT2 C + CFIm complex + Intron 14 (600bp) 4: biotinylated CCAT2 G + CFIm complex 5: biotinylated CCAT2 T + CFIm complex 6: biotinylated CCAT2 C + CFIm complex
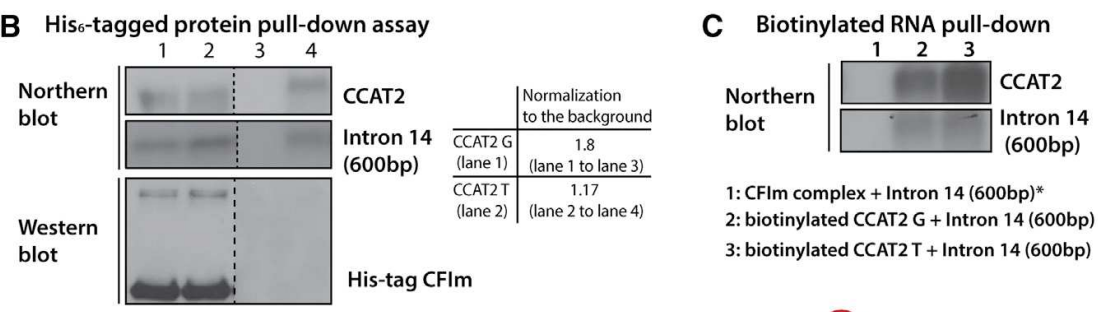

1: CFIm complex + Intron $14(600 \mathrm{bp})^{2}$ 2: biotinylated CCAT2 $\mathrm{G}+$ Intron 14 (600 bp) 3: biotinylated CCAT2 T + Intron 14 (600bp)

1: CCAT2 G + CFIm complex (his-tagged)+ Intron 14 (600bp) 2: CCAT2 T + CFIm complex (his 6 -tagged)+ Intron $14(600 \mathrm{bp})$ 3: CCAT2 G + Intron 14 (600bp)

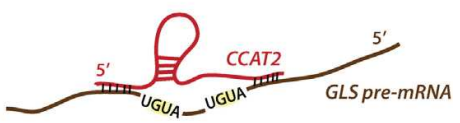

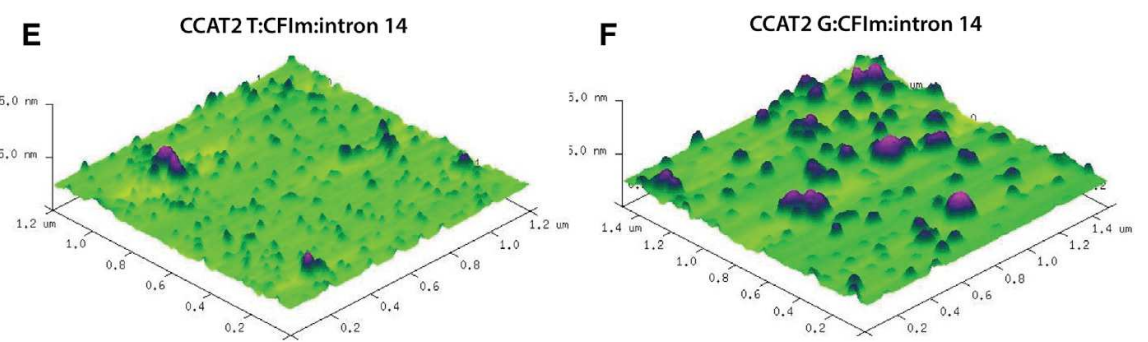
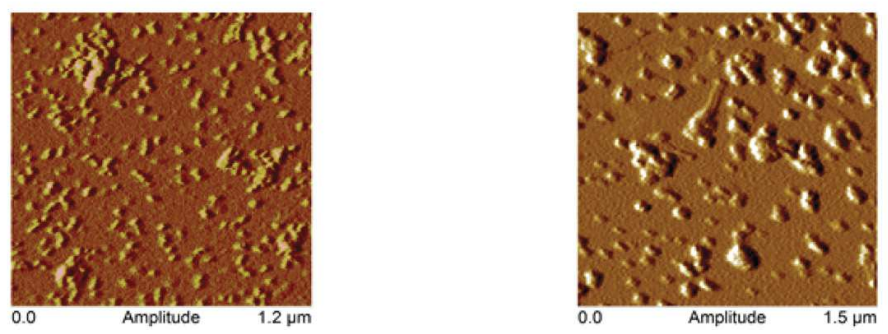

Figure 4. The rs6983267 SNP Affects the Interaction of CCAT2 with the CFIm Protein Complex

(A) Western blot analysis of the proteins pulled down with the MS2-CCAT2 vectors (G, T, A, C, and DEL) showing the presence of CFIm25 for the G allele and CFIm68 for the T allele.

(B) Northern blot analysis showing the presence of CCAT2 and intron 14 (600 bp fragment) in the lysate pulled down with TALON resin (upper panel). Western blot analysis showing the presence of the $\mathrm{His}_{6}$-tagged CFIm complex in the lysate pulled down with the TALON resin (lower panel).

(C) Northern blot analysis showing the presence of CCAT2 and intron 14 (600 bp fragment) in the lysate pulled down with Streptavidin beads. Lane 1 marked with the star symbol is identical to lane 3 in Figure S4D. Schematic illustration of the interaction of CCAT2 with GLS pre-mRNA (representation is not at scale).

(D) Northern blot analysis showing the presence of CCAT2 and intron 14 (600 bp fragment) in the lysate pulled down with Streptavidin beads (upper panel). Western blot analysis showing the presence CFIm25, monomer $(26 \mathrm{kDa})$ and dimer (64 kDa), and His ${ }_{6}$-tagged CFIm68 (38 kDa) (lower panel).

(E and F) AFM images of CCAT2:CFIm:intron 14 quaternary complex including either CCAT2 T allele (E) or CCAT2 G allele (F).

See also Figures S4 and S5 and Table S3.

$4 \mathrm{E}$ and $4 \mathrm{~F})$. Particles of substantial size were detected when scanning the mica surface, suggesting the formation of potential CCAT2:CFIm:intron14 complexes, with higher frequency for the $\mathrm{G}$ allele compared to the $\mathrm{T}$ allele (Figures $4 \mathrm{E}$ and $4 \mathrm{~F}$ ), while the individual components (CFIm protein complex, CCAT2 RNA, and intron 14 RNA) appeared to be evidently smaller (Figures S5B-S5D). Moreover, when measuring the diameter of the complexes ( $G$ allele complex, $226.706 \mathrm{~nm}$; T allele complex, $182.844 \mathrm{~nm}$ ), we found that it corresponds approximately to the sum of the diameter of individual components (CCAT2, $81.865 \mathrm{~nm}$; CFIm, $67.999 \mathrm{~nm}$; intron 14, $48.360 \mathrm{~nm}$ ).

Collectively, these findings suggested that: (1) GLS pre-mRNA impacts the interaction of CCAT2 with CFIm complex; (2) CCAT2 may be acting as a scaffold or assembly platform, promoting the selection of the poly(A) site in intron 14 of GLS pre-mRNA by directly binding both the pre-mRNA and the CFIm complex; and (3) the formation of the RNA:RNA:protein complex is dependent on the rs6983267 SNP and the secondary structure of CCAT2.

As an additional layer of regulation, we discovered that MYC is a transcription factor for NUDT21 (data available from authors upon request).

\section{GAC Promotes Metastases and Cell Proliferation}

We proceeded with evaluating the contribution of GAC to aggressiveness of CRC. Considering that we have previously demonstrated that CCAT2 promotes metastases (Ling et al., 2013b), we first assessed the in vitro migration potential of HCT116 CCAT2-overexpressing cells treated with either the allosteric inhibitor 968 or siRNA for GLS (Katt et al., 2012). We 

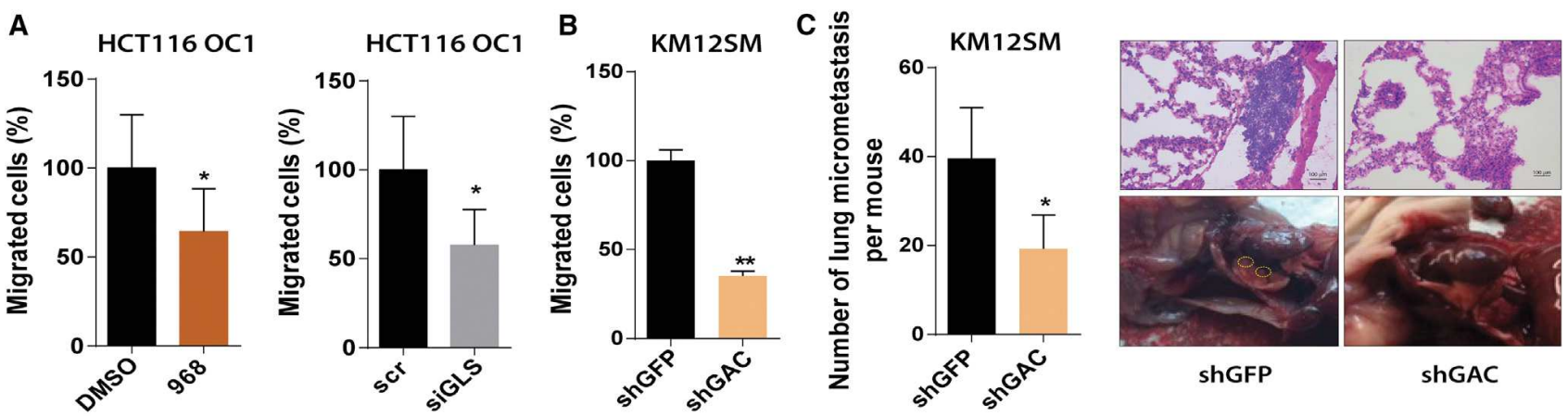

D

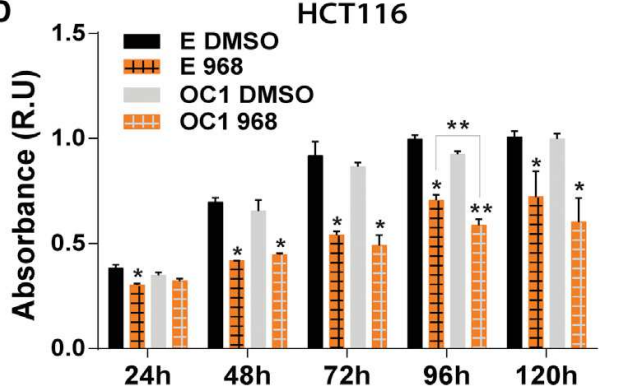

$\mathbf{F}$

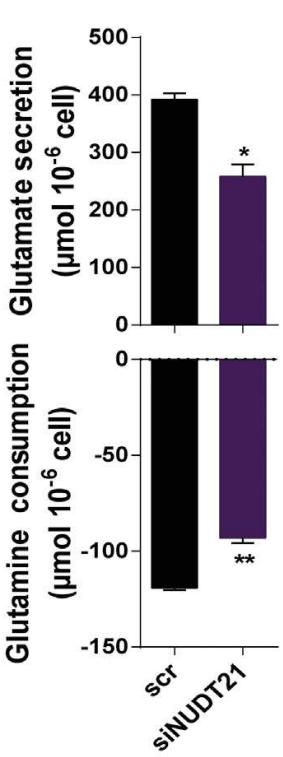

G

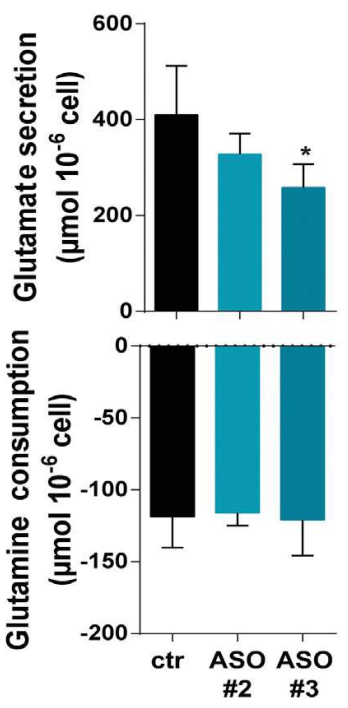

Figure 5. GLS Promotes In Vivo Metastases and In Vitro Cell Proliferation and Migration

(A) Migration of HCT116 OC1 cells (GG genotype) treated with the inhibitor 968 and DMSO (left panel) and with siGLS and scrambled siRNA (right panel).

(B) Migration of KM12SM cells (GT genotype) with stable downregulation of GAC. KM12SM shGFP cells represent the control cells.

(C) Number of the lung micrometastases for two groups (shGFP, 4 mice; shGAC, 4 mice) assessed by IHC (left panel). IHC images showing micrometastases in the three groups and images showing the presence or absence of lung metastases for mice injected in the tail vein with KM12SM shGFP and shGAC cells, respectively (right panel).

(D and E) Growth curves for HCT116 OC1 and control cells (GG genotype) treated with DMSO (control) or the GLS allosteric inhibitor 968 (10 $\mu$ M) (D) and KM12SM cells (GT genotype) with stable downregulation of GAC (E).

( $F$ and G) Glutamine and glutamate concentration in the media relative to the empty well $24 \mathrm{hr}$ after seeding HCT116 CCAT2-overexpressing cells (OC1, GG genotype) transfected with siRNA against NUDT21 and scrambled (F) and ASOs for inhibiting the binding sites of CFIm25 (G).

Results are presented as normalized mean values \pm SD. See also Figure S6 and Table S4.

observed a reduction by half of the migration in the cells where GLS was either inhibited or downregulated (Figure 5A). We next assessed the individual contribution of GAC to the migration, in KM12SM cells with stable downregulation of the isoform (Figure S6A), and found that $60 \%$ fewer cells migrated when GAC expression was reduced (Figure 5B). We then injected the KM12SM stable clones in the tail vein of nude mice, sacrificed the mice 8 weeks after injections, and evaluated the in-lung macro- and micrometastases. Supporting our in vitro results, the incidence of metastases to the lung was $50 \%$ higher in the mice injected with the control cells (shGFP) compared to the shGAC group (Figure $5 \mathrm{C}$ ). Moreover, when we assessed the proliferation of HCT116 control and CCAT2overexpressing cells treated with the GLS inhibitor 968, we found that cells overexpressing CCAT2 were more sensitive to GLS (GAC in this case) inhibition, implying that cells with high CCAT2 expression are dependent on GAC for survival (Figure 5D) (Katt et al., 2012; Wang et al., 2010a). Similar results were obtained when using KM12SM cells with GAC downregulation compared to control cells in vitro (Figure 5E). Additional confirmation of the higher dependency of the CCAT2 G allele on GAC was provided by the colony formation assay for $\mathrm{NIH}$ 3Т3 cells transfected with the CCAT2-overexpressing vectors (Figures S6B and S6C). 
Please cite this article in press as: Redis et al., Allele-Specific Reprogramming of Cancer Metabolism by the Long Non-coding RNA CCAT2, Molecular Cell (2016), http://dx.doi.org/10.1016/j.molcel.2016.01.015

We next sought to determine if the shift in GLS isoform expression and CFIm25 is responsible for the marked metabolic changes observed in cells overexpressing CCAT2. We therefore modulated the expression of the isoforms using the ASOs and downregulated NUDT21 in HCT116 CCAT2-overexpressing cell line (OC1) and measured the extracellular lactate concentration and glutamine metabolism. We observed that downregulation of NUDT21 significantly decreased lactate and glutamate secretion and glutamine consumption similarly to the effects of CCAT2 overexpression in the same cell line (Figures S6D and $5 F)$. However, these metabolic changes appeared to only partly mirror the metabolic effects of CCAT2 overexpression, suggesting there are additional layers of regulations independent of NUDT21, most likely through the bona fide cancer metabolism modulator and CCAT2 target, MYC. On the other hand, the switch in GLS isoforms reflected in lower secretion of glutamate with the glutamine consumption remaining relatively constant but had a modest effect on the extracellular levels of lactate (Figures $5 \mathrm{G}$ and S6E). These findings suggested that GLS is not the only contributor to CCAT2-induced metabolic profile. We hypothesized that other metabolic targets might be regulated by CCAT2 via the same mechanism; thus, we performed Affymetrix HTA 2.0 array to compare the whole transcriptome splicing pattern in HCT116 CCAT2-overexpressing $\mathrm{G}$ and T allele cells. Pathway analysis revealed that several genes associated with two major metabolic pathways, "Metabolism of Carbohydrates" and "Fructose and Mannose Metabolism," are significantly spliced between the CCAT2 G and T alleles (Table S4). Moreover, validating our previous results, we identified a negative splicing index $(\mathrm{SI}=-1.19)$ for $G L S$ for the exclusion junction connecting exon 14 and exon 15, suggesting higher signal for the exclusion junction in the T allele-expressing cells. This translates into less GAC being spliced in the T allele cells compared to the $\mathrm{G}$ allele cells, supportive of our findings (Figure S6F).

Collectively, these data demonstrate that GAC adds to the CRC phenotype; however, it is not solely responsible for the metabolic phenotype observed in cells overexpressing CCAT2.

\section{CCAT2-CFIm-GLS Regulation Axis in CRC Tumors}

We continued with evaluating the expression pattern of CCAT2, GLS, NUDT21, and CPSF6 in colon tumors by analyzing the publicly available TCGA database of colon cancer (http:// cancergenome.nih.gov/). We first compared 18 normal samples to 193 tumor samples and identified an enrichment of the GAC isoform, as well as NUDT21 and CPSF6 in tumor tissue, whereas KGA showed the opposite pattern (Figures $6 \mathrm{~A}-6 \mathrm{D}$ ). We further analyzed the associations between CCAT2, NUDT21, CPSF6, $G A C$, and KGA in the TCGA dataset of colon cancer samples (Cancer Genome Atlas Network, 2012) and detected direct correlations of CCAT2, CPSF6, and NUDT21 with GAC $\left(r_{s}=0.26, \mathrm{p}=\right.$ $0.0006 ; r_{s}=0.68, \mathrm{p}<0.0001 ;$ and $r_{s}=0.72, \mathrm{p}<0.0001$, respectively; Figure $\mathrm{S} 7 \mathrm{~A}$ ) and inverse correlations between CCAT2, CPSF6, NUDT21, and KGA $\left(r_{s}=-0.17, \mathrm{p}=0.0271 ; r_{s}=-0.47\right.$, $\mathrm{p}<0.0001$; and $r_{s}=-0.60, \mathrm{p}<0.0001$; Figure $\left.\mathrm{S} 7 \mathrm{~A}\right)$, as well as between KGA and GAC $\left(r_{s}=-0.590, \mathrm{p}<0.0001\right)$ (Figure S7A). We also obtained significant direct associations of CCAT2 with CPSF6 and NUDT21 $\left(r_{s}=0.20, \mathrm{p}=0.0082\right.$ and $r_{s}=0.26, \mathrm{p}=$
0.0007; Figure S7A). We did not find any significant correlations between the expression of MYC and NUDT21, GAC, or KGA. Since our in vitro findings advanced the concept that CCAT2 $G$ allele is promoting the expression of GAC, we compared the levels of GAC and KGA between patients having GG, GT, and TT genotypes. We observed a significant association with the genotypes for $G A C$, having the highest expression in patients with GG genotype, but not for KGA (Figures 6E and S7B). Similarly, we did not find any association of NUDT21 or MYC with the genotypes (Figures S7C and S7D). These results suggested the molecular mechanism uncovered in vitro is present in CRC patients. Moreover, we analyzed the correlation between the expression of the two isoforms and the overall survival of patients from the TCGA dataset and observed a significant association of high GAC expression combined with low KGA expression with shorter overall survival (Figure S7E). This suggested that the GAC isoform may accelerate the progression of cancer. In addition, we interrogated the TCGA colon cancer dataset for genes that significantly correlate with the IncRNA and performed gene set enrichment analysis (GSEA) and ingenuity pathway analysis (IPA) (QIAGEN) to identify the CCAT2 gene signatures. Various metabolically relevant pathways were found significantly associated with CCAT2 expression by both analyses (Figures 7A and $7 \mathrm{~B})$. We further inquired as to whether the genes that were found significantly correlated with CCAT2 expression were also associated with the genotypes of rs6983267 SNP. We repeated the GSEA and screened for pathways that correlated with either of the genotypes (FDR q value $<0.25$ and nominal $p$ value $<0.05$ ). We identified various metabolic and RNA processing pathways that were associated with certain genotypes (Figure 7C). Interestingly, several of the pathways were related to the ones identified by the Affymetrix HTA 2.0 array (highlighted in green in Figure $7 C$ ), suggesting that CCAT2 may modulate cellular metabolism in CRC patients through a network of metabolic genes regulated most likely via the same mechanism of alternative splicing (see Table S4).

To assess the protein expression of CFIm68, CFIm25, GAC, and KGA, we performed western blot analysis on paired normal mucosae and CRC samples (patient cohort \#1) and identified the same high protein levels of CFIm25 and GAC in tumor tissue compared to normal mucosae for $61.5 \%(8 / 13)$ of the pairs (Figure 6F). As for the KGA isoform, protein levels were mostly lower in tumor samples or comparable to the levels in normal samples (Figure 6F). The $68 \mathrm{kDa}$ subunit of the CFIm complex was either very low or not expressed in approximately half of the paired samples (7/13), while in the rest of the pairs it was clearly overexpressed in tumors (Figure S7F). We also measured CCAT2 expression by qRT-PCR in the same set of samples and confirmed a positive correlation between CCAT2, CFIm25, and GAC for $69.2 \%$ of the samples (Figures 6F, 6G, S7G, and $\mathrm{S} 7 \mathrm{H})$. Moreover, the samples that had elevated levels of CCAT2 displayed a high GAC/KGA ratio (GAC/KGA $=2-5.7)$ (Figure S7I). We repeated the measurements in a second set of paired normal mucosae and CRC samples (patient cohort \#2) and obtained similar results (Figures S7J and S7K). Both CFIm25 and GAC proteins were overexpressed in 60\% (3/5) of tumor samples. In all samples, elevated protein levels of CFIm25 and GAC matched the increased RNA levels of 


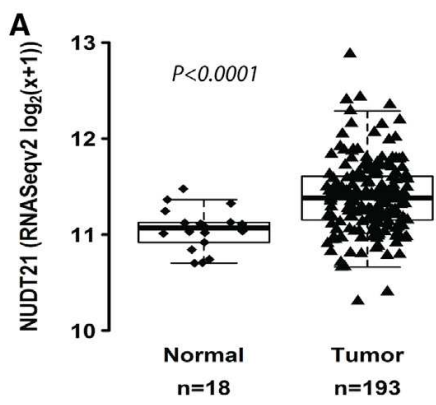

D

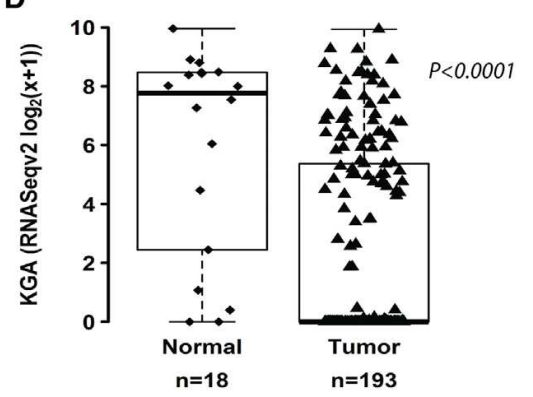

E

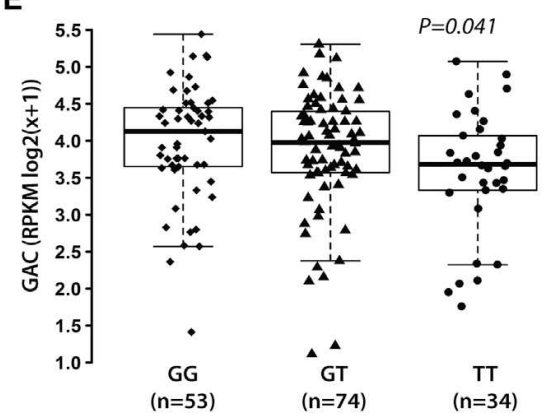

B

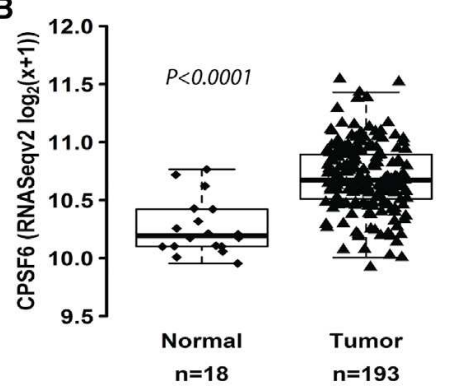

$\mathbf{F}$
C

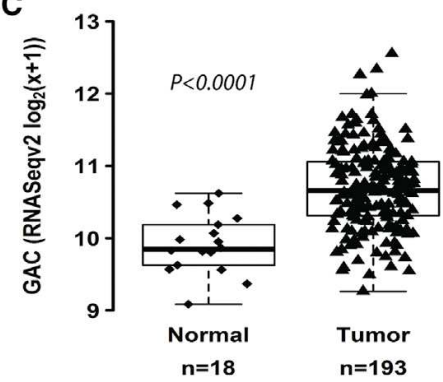

F (kDa)

Patient Cohort\#1

G

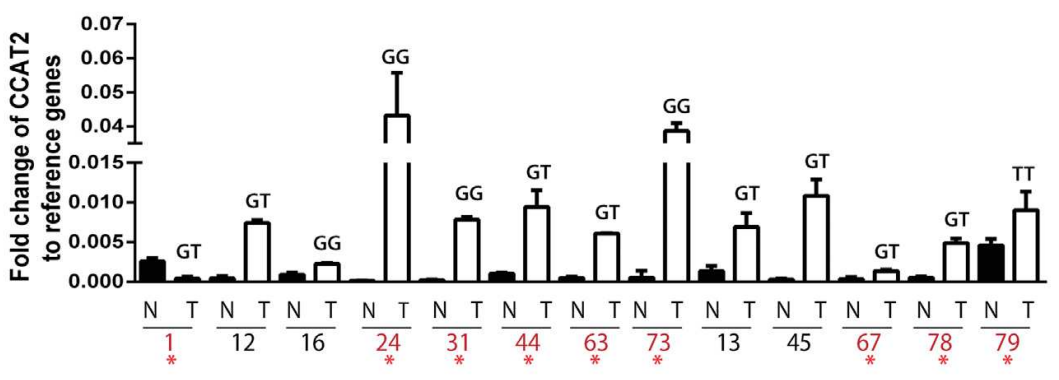

Figure 6. CCAT2, NUDT21, CPSF6, and GLS Expression Pattern in TCGA Dataset and CRC Patient Samples

(A-D) Analysis of NUDT21 (A), CPSF6 (B), GAC (C), and KGA (D) mRNA expression in TCGA RNA-seq colon cancer sample set.

(E) Association of GAC mRNA expression with the genotypes (GG, GT, and TT) of the rs6983267 SNP for CRC patients (TCGA RNA-seq dataset).

(F) Western blot analysis of CFIm25, GAC, and KGA expression in paired CRC samples (patient cohort \#1).

(G) qRT-PCR analysis for CCAT2 in the same paired CRC samples (patient cohort \#1).

Results are presented as normalized mean values \pm SD. See also Figure S7.

CCAT2. Additionally, we have genotyped the tumors from patient cohort \#1 and found that the association of GG genotype with higher GAC and CFIm25 protein expression (samples marked in red) was consistent for $75 \%$ of patients (3/4), while for the GT genotype the association was present in only $62.5 \%$ of patients (5/8) (Figure 6G). No conclusion can be drawn for the $\Pi T$ genotype due to the limited representation of the genotype in this cohort (one patient). Altogether, this mechanism of GLS regulation was detected in the majority of the analyzed CRC cases $(61 \%, 11 / 18)$.

\section{DISCUSSION}

Our study demonstrates that the rs6983267 SNP (G/T) induces changes in the secondary structure of the IncRNA, CCAT2, initiating a domino effect mechanism, which leads to allele-specific reprograming of cellular energy metabolism. The consequence of the allele-specific interaction between CCAT2, CFIm, and GLS pre-mRNA appears to be the selection of the poly $(A)$ site within intron 14 of GLS, resulting in the preferential splicing to the GAC isoform, the more catalytically active of the two GLS isoforms (Cassago et al., 2012). Although a recent study has described the negative regulation of GLS by CFIm25 in glioblastoma via 3' UTR processing mechanisms (Masamha et al., 2014), suggesting a tumor-suppressive role for CFIm25, in our model, neither of the GLS isoforms is subjected to $3^{\prime}$ UTR shortening (data not shown). In the context of these findings and considering that CCAT2 is not expressed in glioblastoma (data not shown), our results reveal an intriguing aspect of IncRNA mechanism of action, namely the ability of an IncRNA to alter the function of the partner RNA-binding protein/complex. The enrichment on metabolites related to TCA cycle that we 
Please cite this article in press as: Redis et al., Allele-Specific Reprogramming of Cancer Metabolism by the Long Non-coding RNA CCAT2, Molecular Cell (2016), http://dx.doi.org/10.1016/j.molcel.2016.01.015

A
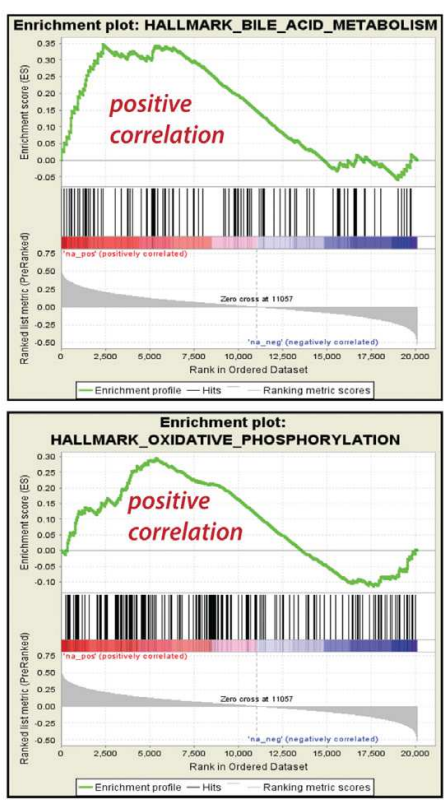

B

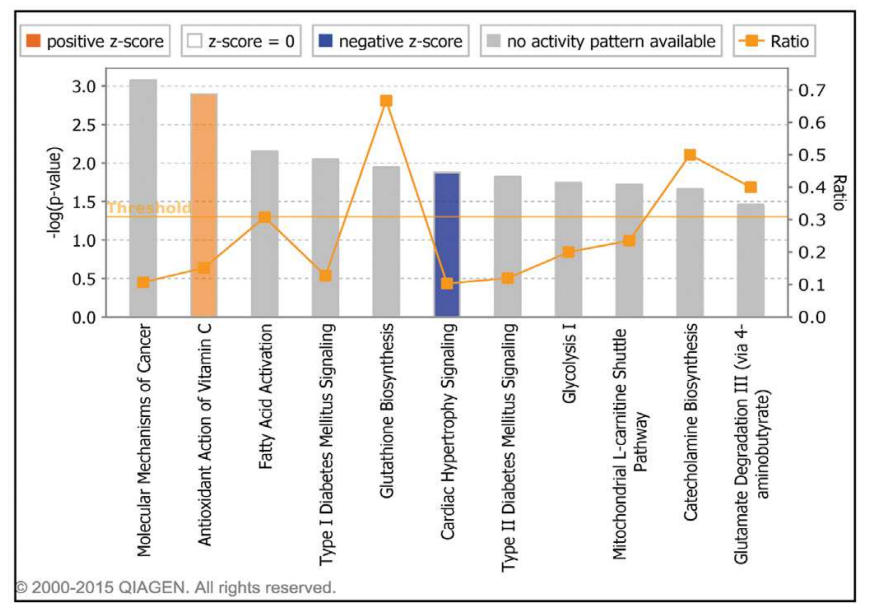

\begin{tabular}{l|c|c|}
\hline \multicolumn{1}{c|}{ Gene } & $r^{2}$ (Spearman) & $p$ value \\
\hline PDHA1 & 0.3715 & $<0.0001$ \\
\hline ATP6V1C1 & 0.3679 & $<0.0001$ \\
\hline VDAC1 & 0.1704 & $<0.0001$ \\
\hline GOT2 & 0.1280 & 0.0132 \\
\hline SLC25A11 & -0.3083 & $<0.0001$ \\
\hline SDHA & -0.3351 & $<0.0001$ \\
\hline ATP5A1 & -0.3967 & $<0.0001$ \\
\hline
\end{tabular}

\begin{tabular}{l|c|c}
\hline \multicolumn{1}{c|}{ Gene } & $r^{2}$ (Spearman) & $p$ value \\
\hline AMACR & 0.5067 & $<0.0001$ \\
\hline PIPOX & 0.3740 & $<0.0001$ \\
\hline SLC23A1 & 0.3194 & $<0.0001$ \\
\hline GCLM & 0.2489 & $<0.0001$ \\
\hline ALDH1L1 & -0.1932 & 0.0002 \\
\hline NPC1 & -0.2539 & $<0.0001$ \\
\hline HSD3B7 & -0.3205 & $<0.0001$ \\
\hline
\end{tabular}

TCGA Colon Cancer dataset

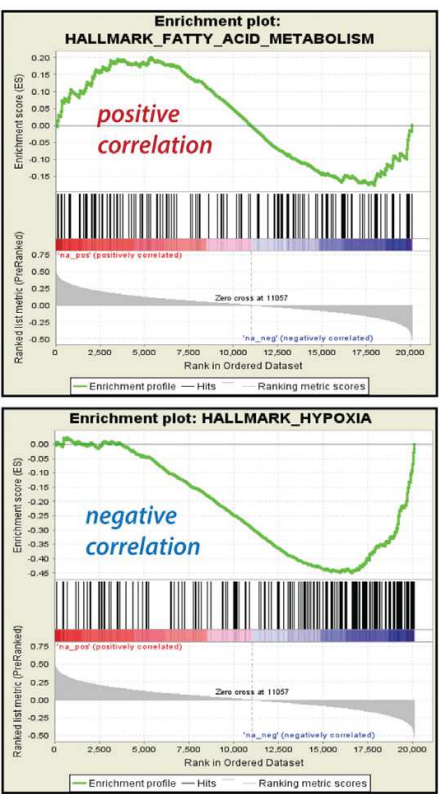

\begin{tabular}{l|c|l}
\hline \multicolumn{1}{c|}{ Gene } & $r^{2}$ (Spearman) & $p$ value \\
\hline PKLR & 0.4293 & $<0.0001$ \\
\hline SLC37A4 & 0.3473 & $<0.0001$ \\
\hline PDK3 & 0.2679 & $<0.0001$ \\
\hline LDHC & 0.2036 & 0.0001 \\
\hline BNIP3L & -0.3524 & $<0.0001$ \\
\hline PFKFB3 & -0.3479 & $<0.0001$ \\
\hline GAPDH & -0.3027 & $<0.0001$ \\
\hline
\end{tabular}

C

\begin{tabular}{l|l|l|l}
\hline Pathway & GG & GT & TT \\
\hline Bile Acid Metabolism & & & \\
\hline Bile Acid and Bile Salt Metabolism & & & \\
\hline Oxidative Phosphorylation & & & \\
\hline Cysteine and Methionine Metabolism & & & \\
\hline Pyruvate Metabolism & & & \\
\hline Glucose Transport & & & \\
\hline Spliceosome & & & \\
\hline mRNA 3' End Processing & & & \\
\hline Fatty Acid Metabolism & & & \\
\hline Hypoxia & & & \\
\hline Metabolism of Carbohydrates & & & \\
\hline Fructose and Mannose Metabolism & & & \\
\hline Glycolysis - Gluconeogenesis & & & \\
\hline Type I Diabetes Mellitus & & & \\
\hline Type II Diabetes Mellitus & & & \\
\hline Diabetes Pathways & & & \\
\hline Dilated Cardiomyopathy & & & \\
\hline Hypertrophic Cardiomyopathy & & & \\
\hline
\end{tabular}

Figure 7. CCAT2 Gene Signature in Colon Cancer Patients-TCGA Dataset

(A and B) Genes associated with CCAT2 were analyzed by gene set enrichment analysis (GSEA) (A) and ingenuity pathway analysis (IPA, QIAGEN) (B). Relevant examples for each analysis are presented in (A) and (B).

(C) Table containing the pathways significantly associated with CCAT2 expression and rs6983267 genotype (FDR q value $<0.25$ and nominal $p$ value $<0.05$ ). Pathways that were positively correlated are marked with red, and the ones that are negatively correlated are marked with blue. Highlighted in green are the pathways found common between GSEA analysis and the Affymetrix HTA 2.0 pathways analysis.

See also Figure $\mathrm{S} 7$ and Table S4.

observed for tumors derived from HCT116 cells overexpressing CCAT2 the G allele are supported by Kaldma and colleagues' findings describing that CRC tumors are not purely glycolytic, but rather dependent on OXPHOS for ATP production (Kaldma et al., 2014).

The aberrant expression of GLS has been reported in many types of cancer, including CRC (Huang et al., 2014) Furthermore, various studies have described GAC as the more abundant isoform in lung adenocarcinoma, head and neck squamous cell carcinoma, kidney renal clear cell carcinoma, and AML (Jacque et al., 2015; van den Heuvel et al., 2012; Xia et al., 2014). Glutamine metabolism has also been associated with genomic instability (Jeong et al., 2013), commonly encountered in CRC and previously shown to be promoted by CCAT2 (Ling et al., 2013b), and appears to be endorsed by the G risk allele. However, it must be stated that CCAT2 is modulating energy metabolism in a general fashion via MYC and in an allele-specific manner via GLS and other metabolic enzymes and/or 
metabolites, whose expression is finely regulated by the interaction of CCAT2 with CFIm. Although the differences in regulation between the $G$ and $T$ alleles may not be impressive, the variation in expression of multiple enzymes/metabolites may have an additive effect towards a clear phenotypical change. The complex mechanism presented in this manuscript encompassing IncRNA, protein complexes, oncogenes, and transcription factors opens several windows for targeted therapy. The metabolic enzyme GLS is already considered a therapeutic target for cancer (Vander Heiden, 2011); however, our work introduces the opportunity of targeting the cancer-specific GAC isoform in particular.

Lastly, our study reveals the complexity and refinement of the interaction networks among the alleles of a non-coding RNA, the components of a protein complex, and the splicing isoforms of a metabolic enzyme that contribute to the malignant transformation and progression of CRC.

\section{EXPERIMENTAL PROCEDURES}

Full details of the Experimental Procedures are presented in the Supplemental Experimental Procedures. Primer sequences and information regarding the antibodies used in this study can be found in Tables S5 and S6.

\section{Patient Samples}

18 paired samples, normal colon mucosa and colon tumor, were used in this study. The samples were obtained from two different sources: The Ruder Boskovic Institute, Croatia (15 paired samples) and University of Ferrara, Italy (5 paired samples). Tissue samples were obtained from fresh surgical specimens frozen in liquid nitrogen and stored at $-80^{\circ} \mathrm{C}$. all the samples were obtained with the patients' informed consent and under the approval and supervision of the institutional review boards. The samples were histologically confirmed prior to use.

\section{In Vivo Models and Tissue Processing}

70 male athymic nude mice were purchased from the National Cancer Institute, Frederick Cancer Research and Development Center (Frederick, MD) and were cared for according to guidelines set forth by the American Association for Accreditation of Laboratory Animal Care and the U.S. Public Health Service policy on Human Care and Use of Laboratory Animals. All mouse studies were approved and supervised by the MD Anderson Cancer Center Institutional Animal Care and Use Committee.

\section{Glucose Uptake Assay}

Cells were plated in 96 -well plates $(25,000$ cells/well) $16 \mathrm{hr}$ before performing the assay. The medium was removed and cells were washed twice with PBS. To the wells containing the blanks, $50 \mu \mathrm{l}$ of PBS was added, while for the wells with the samples $50 \mu \mathrm{l}$ of 2-NBDG $(100 \mu \mathrm{M})$ (Sigma) was added and the mixture was incubated for $10 \mathrm{~min}$ at $37^{\circ} \mathrm{C}$ and $5 \% \mathrm{CO}_{2}$. After incubation, cells were washed twice with ice-cold PBS to stop the reaction, and $200 \mu \mathrm{l}$ PBS was added to each well. Fluorescence measurements were performed at $485 / 520 \mathrm{~nm}$ with the PHERAstar FS (BMG Labtech).

\section{Lactate Production Assay}

To measure lactate production, cells that were $80 \%$ confluent were replenished with fresh medium. Aliquots of the medium were removed at the indicated time points ( $24 \mathrm{or} 48 \mathrm{hr}$ ) for measurement of lactate using an Accutrend lactate analyzer (Roche). At each time point, cell numbers were also counted for normalization of lactate generation.

\section{Intracellular Glutamate Assay}

The glutamate concentration in cell lysates was measured using the Glutamate Colorimetric Assay Kit (Biovision) following the manufacturer's protocol.
Briefly, $1 \times 10^{6}$ cells per tested sample were homogenized in $100 \mu$ l of assay buffer and centrifuged to remove insoluble material. $100 \mu \mathrm{l}$ of reaction mix was added to the supernatant, standards, and background control samples, and after $30 \mathrm{~min}$ incubation at $37^{\circ} \mathrm{C}$, absorbance was measured at $450 \mathrm{~nm}$ with a SpectraMax Plus384 MicroPlate Reader (Molecular Devices). The experiment was performed in quadruplicate.

\section{SUPPLEMENTAL INFORMATION}

Supplemental Information includes Supplemental Experimental Procedures, seven figures, and six tables and can be found with this article online at http://dx.doi.org/10.1016/j.molcel.2016.01.015.

\section{AUTHOR CONTRIBUTIONS}

Conceived and designed the experiments: R.S.R., L.E.V., W.L., J.F.O., A.F.F., M.S.R., M.I., G.B., M.F.F., S.H., W.R.W., A.L.B.A., S.M.G.D., and G.A.C. Performed the experiments: R.S.R., L.E.V., W.L., J.F.O., C.R.-A., D.A., B.P., A.T., Y.C., K.V.R., S.C., M.S., Y.A., L.H.C., G.Y.H., P.M., M.S.R., T.C.I., L.V., and H.L. Analyzed the data: R.S.R., L.E.V., W.L., J.F.O., C.I., C.R.-A., D.A., A.T., A.F.F., L.V., G.K., J.A.B., M.R., A.L.B.A., S.M.G.D., and G.A.C. Contributed reagents/materials/analysis tools: L.H., S.K., R.G., G.L., S.Y.L., R.C.B., P.H., M.G.R., I.B.-N., and G.L.-B. Wrote the first draft of the manuscript: R.S.R., S.M.G.D., A.L.B.A., and G.A.C. Contributed to the writing of the manuscript: R.S.R., S.M.G.D., A.L.B.A., and G.A.C. Agree with manuscript results and conclusions: all authors. Critical revision of the manuscript for important intellectual content: all authors. Statistical analysis: C.I., L.H., G.K., M.R., and H.L. Study supervision: S.M.G.D. and G.A.C.

\section{ACKNOWLEDGMENTS}

G.A.C. is The Alan M. Gewirtz Leukemia \& Lymphoma Society Scholar. Work in G.A.C.'s laboratory is supported in part by the $\mathrm{NIH} / \mathrm{NCl}$ grants $1 \mathrm{UH} 2 \mathrm{TR} 00943-$ 01 and 1 R01 CA182905-01, the UT MD Anderson Cancer Center SPORE in Melanoma grant from NCl (P50 CA093459), Aim at Melanoma Foundation and the Miriam and Jim Mulva research funds, the Brain SPORE (2P50CA127001), the Center for Radiation Oncology Research Project, the Center for Cancer Epigenetics Pilot project, a 2014 Knowledge GAP MDACC grant, a CLL Moonshot pilot project, the UT MD Anderson Cancer Center Duncan Family Institute for Cancer Prevention and Risk Assessment, a SINF grant in colon cancer, the Laura and John Arnold Foundation, the RGK Foundation, and the Estate of C.G. Johnson, Jr. I.B.-N. was financed by a grant entitled Non-Invasive Intelligent Systems for Colorectal Cancer Diagnosis and Prognosis Based on circulating miRNAs Integrated in the Clinical Workflow INTELCOR. S.M.G.D., A.L.B.A., and D.A. are supported by the São Paulo Research Foundation FAPESP under grants 2014/15968-3, 2014/20673-2, and $2014 / 17820-3$, respectively. W.L. was partly supported by grants from The University of Texas MD Anderson Cancer Center Sheikh Ahmed Bin Zayed Al Nahyan Center for Pancreatic Cancer Research. J.A.B. was supported by the Cancer Center Support Grant (P30 CA016672), and the HP imaging program of the Small Animal Facility (SAIF) was supported by the Cancer Prevention and Research Institutes of Texas grant RP-101243P5. H.L. was supported by $\mathrm{NIH} / \mathrm{NCl}$ grant R01CA175486, a grant (RP140462) from the Cancer Prevention and Research Institute of Texas, and the R. Lee Clark Fellow Award from The Jeanne F. Shelby Scholarship Fund. We would like to thank Dr. Riccardo Fodde (Erasmus Medical Center) for the scientific support and advice, Dr. Sylvie Doublie for the generous gift of CFIm25 and CFIm68 plasmids, Dr. Riccardo Spizzo for generating the HCT116 CCAT2 stable clones, and Dr. Thomas A. Cooper for the generous gift of RG6 plasmid. We would also like to thank the IM Bioscope II-UT core facility and Dr. Ana Maria Zaske for performing the AFM imaging. Additionally, we thank the members of Flow Cytometry \& Cellular Imaging Core Facility (Department of Leukemia) and Dr. Jared Burks for performing the VECTRA imaging and analysis and Drs. Liuqing Yang (MDACC), Yibin Zhou (IBT), Clifford Stephan (IBT), Shawn Bratton (MDACC), Charles V. Kingsley (MDACC), Jorge Delacerda (MDACC), Iva Maestri (University of Ferrara), and Linda Ulazzi (University of Ferrara) for the technical 
support. We also would like to thank the Biological Imaging Facility and the Protein Purification and Bioassay Laboratories (LNBio/CNPEM/Brazil) for access to the equipment.

Received: April 3, 2015

Revised: October 23, 2015

Accepted: January 8, 2016

Published: February 4, 2016

\section{REFERENCES}

Bester, A.C., Roniger, M., Oren, Y.S., Im, M.M., Sarni, D., Chaoat, M., Bensimon, A., Zamir, G., Shewach, D.S., and Kerem, B. (2011). Nucleotide deficiency promotes genomic instability in early stages of cancer development. Cell 145, 435-446.

Boroughs, L.K., and DeBerardinis, R.J. (2015). Metabolic pathways promoting cancer cell survival and growth. Nat. Cell Biol. 17, 351-359.

Cancer Genome Atlas Network (2012). Comprehensive molecular characterization of human colon and rectal cancer. Nature 487, 330-337.

Carroll, P.A., Diolaiti, D., McFerrin, L., Gu, H., Djukovic, D., Du, J., Cheng, P.F., Anderson, S., Ulrich, M., Hurley, J.B., et al. (2015). Deregulated Myc requires MondoA/Mlx for metabolic reprogramming and tumorigenesis. Cancer Cell 27, 271-285.

Cassago, A., Ferreira, A.P., Ferreira, I.M., Fornezari, C., Gomes, E.R., Greene, K.S., Pereira, H.M., Garratt, R.C., Dias, S.M., and Ambrosio, A.L. (2012). Mitochondrial localization and structure-based phosphate activation mechanism of Glutaminase C with implications for cancer metabolism. Proc. Natl. Acad. Sci. USA 109, 1092-1097.

Chen, J.Q., and Russo, J. (2012). Dysregulation of glucose transport, glycolysis, TCA cycle and glutaminolysis by oncogenes and tumor suppressors in cancer cells. Biochim. Biophys. Acta 1826, 370-384.

Elkon, R., Ugalde, A.P., and Agami, R. (2013). Alternative cleavage and polyadenylation: extent, regulation and function. Nat. Rev. Genet. 14, 496-506.

Gao, P., Tchernyshyov, I., Chang, T.C., Lee, Y.S., Kita, K., Ochi, T., Zeller, K.I., De Marzo, A.M., Van Eyk, J.E., Mendell, J.T., and Dang, C.V. (2009). c-Myc suppression of miR-23a/b enhances mitochondrial glutaminase expression and glutamine metabolism. Nature 458, 762-765.

Huang, F., Zhang, Q., Ma, H., Lv, Q., and Zhang, T. (2014). Expression of glutaminase is upregulated in colorectal cancer and of clinical significance. Int. J. Clin. Exp. Pathol. 7, 1093-1100.

Jacque, N., Ronchetti, A.M., Larrue, C., Meunier, G., Birsen, R., Willems, L., Saland, E., Decroocq, J., Thiago, T.T., Lambert, M., et al. (2015). Targeting glutaminolysis has antileukemic activity in acute myeloid leukemia and synergizes with BCL-2 inhibition. Blood 126, 1346-1356.

Jeong, S.M., Xiao, C., Finley, L.W., Lahusen, T., Souza, A.L., Pierce, K., Li, Y.H., Wang, X., Laurent, G., German, N.J., et al. (2013). SIRT4 has tumor-suppressive activity and regulates the cellular metabolic response to DNA damage by inhibiting mitochondrial glutamine metabolism. Cancer Cell 23, 450-463.

Kaldma, A., Klepinin, A., Chekulayev, V., Mado, K., Shevchuk, I., Timohhina, N., Tepp, K., Kandashvili, M., Varikmaa, M., Koit, A., et al. (2014). An in situ study of bioenergetic properties of human colorectal cancer: the regulation of mitochondrial respiration and distribution of flux control among the components of ATP synthasome. Int. J. Biochem. Cell Biol. 55, 171-186.

Katt, W.P., Ramachandran, S., Erickson, J.W., and Cerione, R.A. (2012) Dibenzophenanthridines as inhibitors of glutaminase $\mathrm{C}$ and cancer cell proliferation. Mol. Cancer Ther. 11, 1269-1278.

Le, A., Lane, A.N., Hamaker, M., Bose, S., Gouw, A., Barbi, J., Tsukamoto, T., Rojas, C.J., Slusher, B.S., Zhang, H., et al. (2012). Glucose-independent glutamine metabolism via TCA cycling for proliferation and survival in B cells. Cell Metab. 15, 110-121.

Ling, H., Fabbri, M., and Calin, G.A. (2013a). MicroRNAs and other non-coding RNAs as targets for anticancer drug development. Nat. Rev. Drug Discov. 12 847-865.
Ling, H., Spizzo, R., Atlasi, Y., Nicoloso, M., Shimizu, M., Redis, R.S., Nishida, N., Gafà, R., Song, J., Guo, Z., et al. (2013b). CCAT2, a novel noncoding RNA mapping to $8 \mathrm{q} 24$, underlies metastatic progression and chromosomal instability in colon cancer. Genome Res. 23, 1446-1461.

Lutz, C.S., and Moreira, A. (2011). Alternative mRNA polyadenylation in eukaryotes: an effective regulator of gene expression. Wiley Interdiscip. Rev. RNA 2, 23-31.

Lyubchenko, Y.L., Shlyakhtenko, L.S., and Ando, T. (2011). Imaging of nucleic acids with atomic force microscopy. Methods 54, 274-283.

Masamha, C.P., Xia, Z., Yang, J., Albrecht, T.R., Li, M., Shyu, A.B., Li, W., and Wagner, E.J. (2014). CFIm25 links alternative polyadenylation to glioblastoma tumour suppression. Nature 510, 412-416.

Mercer, T.R., Dinger, M.E., and Mattick, J.S. (2009). Long non-coding RNAs: insights into functions. Nat. Rev. Genet. 10, 155-159.

Millevoi, S., Loulergue, C., Dettwiler, S., Karaa, S.Z., Keller, W., Antoniou, M., and Vagner, S. (2006). An interaction between U2AF 65 and CF I(m) links the splicing and $3^{\prime}$ end processing machineries. EMBO J. 25, 4854-4864.

Naganuma, T., Nakagawa, S., Tanigawa, A., Sasaki, Y.F., Goshima, N., and Hirose, T. (2012). Alternative $3^{\prime}$-end processing of long noncoding RNA initiates construction of nuclear paraspeckles. EMBO J. 31, 4020-4034.

Nagasaki, H., Arita, M., Nishizawa, T., Suwa, M., and Gotoh, O. (2006) Automated classification of alternative splicing and transcriptional initiation and construction of visual database of classified patterns. Bioinformatics 22, 1211-1216.

Orengo, J.P., Bundman, D., and Cooper, T.A. (2006). A bichromatic fluorescent reporter for cell-based screens of alternative splicing. Nucleic Acids Res. 34, e148.

Rathore, M.G., Saumet, A., Rossi, J.F., de Bettignies, C., Tempé, D., Lecellier, C.H., and Villalba, M. (2012). The NF-kB member p 65 controls glutamine metabolism through miR-23a. Int. J. Biochem. Cell Biol. 44, 1448-1456.

Redis, R.S., Sieuwerts, A.M., Look, M.P., Tudoran, O., Ivan, C., Spizzo, R., Zhang, X., de Weerd, V., Shimizu, M., Ling, H., et al. (2013). CCAT2, a novel long non-coding RNA in breast cancer: expression study and clinical correlations. Oncotarget 4, 1748-1762.

Stine, Z.E., Walton, Z.E., Altman, B.J., Hsieh, A.L., and Dang, C.V. (2015). MYC, Metabolism, and Cancer. Cancer Discov. 5, 1024-1039.

Tian, B., Pan, Z., and Lee, J.Y. (2007). Widespread mRNA polyadenylation events in introns indicate dynamic interplay between polyadenylation and splicing. Genome Res. 17, 156-165.

Tomlinson, I., Webb, E., Carvajal-Carmona, L., Broderick, P., Kemp, Z., Spain, S., Penegar, S., Chandler, I., Gorman, M., Wood, W., et al.; CORGI Consortium (2007). A genome-wide association scan of tag SNPs identifies a susceptibility variant for colorectal cancer at 8q24.21. Nat. Genet. 39, 984-988.

Tuupanen, S., Turunen, M., Lehtonen, R., Hallikas, O., Vanharanta, S., Kivioja, T., Björklund, M., Wei, G., Yan, J., Niittymäki, I., et al. (2009). The common colorectal cancer predisposition SNP rs6983267 at chromosome 8q24 confers potential to enhanced Wnt signaling. Nat. Genet. 41, 885-890.

van den Heuvel, A.P., Jing, J., Wooster, R.F., and Bachman, K.E. (2012). Analysis of glutamine dependency in non-small cell lung cancer: GLS1 splice variant GAC is essential for cancer cell growth. Cancer Biol. Ther. 13, 1185-1194.

Vander Heiden, M.G. (2011). Targeting cancer metabolism: a therapeutic window opens. Nat. Rev. Drug Discov. 10, 671-684.

Wang, J., Liu, X., Wu, H., Ni, P., Gu, Z., Qiao, Y., Chen, N., Sun, F., and Fan, Q. (2010a). CREB up-regulates long non-coding RNA, HULC expression through interaction with microRNA-372 in liver cancer. Nucleic Acids Res. 38, 53665383.

Wang, J.B., Erickson, J.W., Fuji, R., Ramachandran, S., Gao, P., Dinavahi, R., Wilson, K.F., Ambrosio, A.L., Dias, S.M., Dang, C.V., and Cerione, R.A (2010b). Targeting mitochondrial glutaminase activity inhibits oncogenic transformation. Cancer Cell 18, 207-219.

Warburg, O., Posener, K., and Negelein, E. (1924). Über den Stoffwechsel der Carcinomzelle. Biochem. Zeitschr 152, 309-344. 
Ward, P.S., and Thompson, C.B. (2012). Metabolic reprogramming: a cancer hallmark even warburg did not anticipate. Cancer Cell 21, 297-308.

Wilusz, J.E., Sunwoo, H., and Spector, D.L. (2009). Long noncoding RNAs: functional surprises from the RNA world. Genes Dev. 23, 1494-1504.

Xia, Z., Donehower, L.A., Cooper, T.A., Neilson, J.R., Wheeler, D.A., Wagner, E.J., and Li, W. (2014). Dynamic analyses of alternative polyadenylation from RNA-seq reveal a $3^{\prime}$-UTR landscape across seven tumour types. Nat. Commun. 5, 5274.

Yang, Q., Gilmartin, G.M., and Doublié, S. (2011). The structure of human cleavage factor $\mathrm{I}(\mathrm{m})$ hints at functions beyond UGUA-specific RNA binding: a role in alternative polyadenylation and a potential link to $5^{\prime}$ capping and splicing. RNA Biol. 8, 748-753.

Yang, F., Zhang, H., Mei, Y., and Wu, M. (2014). Reciprocal regulation of HIF$1 \alpha$ and lincRNA-p21 modulates the Warburg effect. Mol. Cell 53, 88-100.

Yoon, J.H., Srikantan, S., and Gorospe, M. (2012). MS2-TRAP (MS2-tagged RNA affinity purification): tagging RNA to identify associated miRNAs. Methods 58, 81-87.

Zhou, Z., Licklider, L.J., Gygi, S.P., and Reed, R. (2002). Comprehensive proteomic analysis of the human spliceosome. Nature 419, 182-185. 


\title{
The origin and evolution of human glutaminases and their atypical C-terminal ankyrin repeats
}

\author{
Received for publication, March 21, 2017, and in revised form, May 11, 2017 Published, Papers in Press, May 19, 2017, DOl 10.1074/jbc.M117.787291
}

\begin{abstract}
Camila Cristina Pasquali $^{\ddagger 1}$, Zeyaul Islam ${ }^{\ddagger 1}$, Douglas Adamoski ${ }^{\ddagger 1}$, Igor Monteze Ferreira ${ }^{\ddagger \S}$, Ricardo Diogo Righeto ${ }^{\uparrow|| 2}$, Jefferson Bettini ${ }^{\natural}$, Rodrigo Villares Portugal", Wyatt Wai-yin Yue ${ }^{\S}$, Ana Gonzalez ${ }^{* *}$, Sandra Martha Gomes Dias ${ }^{\ddagger 3}$, and Andre Luis Berteli Ambrosio ${ }^{\ddagger 4}$

From the ${ }^{\ddagger}$ Laboratório Nacional de Biociências, Centro Nacional de Pesquisa em Energia e Materiais, Campinas, São Paulo 13083-970, Brazil, the ${ }^{\S}$ Structural Genomics Consortium, University of Oxford, Oxford OX3 7DQ, United Kingdom, the "Laboratório Nacional de Nanotecnologia, Centro Nacional de Pesquisa em Energia e Materiais, Campinas, São Paulo 13083-970, Brazil, the "School of Electrical and Computer Engineering, University of Campinas, São Paulo 13083-852, Brazil, and the **Stanford Synchrotron Radiation Lightsource, SLAC National Accelerator Laboratory, Menlo Park, California 94025
\end{abstract}

Edited by Norma Allewell

On the basis of tissue-specific enzyme activity and inhibition by catalytic products, Hans Krebs first demonstrated the existence of multiple glutaminases in mammals. Currently, two human genes are known to encode at least four glutaminase isoforms. However, the phylogeny of these medically relevant enzymes remains unclear, prompting us to investigate their origin and evolution. Using prokaryotic and eukaryotic glutaminase sequences, we built a phylogenetic tree whose topology suggested that the multidomain architecture was inherited from bacterial ancestors, probably simultaneously with the hosting of the proto-mitochondrion endosymbiont. We propose an evolutionary model wherein the appearance of the most active enzyme isoform, glutaminase C (GAC), which is expressed in many cancers, was a late retrotransposition event that occurred in fishes from the Chondrichthyes class. The ankyrin (ANK) repeats in the glutaminases were acquired early in their evolution. To obtain information on ANK folding, we solved two high-resolution structures of the ANK repeat-containing $\mathrm{C}$ termini of both kidney-type glutaminase (KGA) and GLS2 isoforms (glutaminase B and liver-type glutaminase). We found that the glutaminase ANK repeats form unique intramolecular contacts through two highly conserved motifs; curiously, this arrangement occludes a region usually involved in ANK-mediated protein-protein interactions. We also solved the crystal structure of full-length KGA and present a small-angle X-ray scattering model for full-

This work was supported by Fundação de Amparo à Pesquisa do Estado de São Paulo Grant 2014/20673-2 (to A. L. B. A.), Grant 2015/25832-4 (to S.M.G.D.), Scholarship 2014/19518-2 (to C.C.P.), Fellowship 2014/ 12663-7 (to Z. I.), Scholarship 2014/17820-3 (to D. A.), and Scholarship 2013/05668-0 (to I. M. F.). The authors declare that they have no conflicts of interest with the contents of this article. The content is solely the responsibility of the authors and does not necessarily represent the official views of the National Institutes of Health.

This article contains supplemental Table S1 and Fig. S1.

The atomic coordinates and structure factors (codes $5 u 0 i, 5 u 0 j, 5 u 0 k$, and $5 u q e$ ) have been deposited in the Protein Data Bank (http://wwpdb.org/).

1 These authors contributed equally to this work.

2 Present address: Center for Cellular Imaging and NanoAnalytics (C-CINA) Biozentrum, University of Basel, Basel, $\mathrm{CH}-4058$, Switzerland.

${ }^{3}$ To whom correspondence may be addressed. E-mail: sandra.dias@Inbio. cnpem.br.

${ }^{4}$ To whom correspondence may be addressed: Laboratório Nacional de Biociências, LNBio, CNPEM, Rua Giuseppe Máximo Scolfaro, 10.000, Pólo II de Alta Tecnologia, Campinas, São Paulo 13083-970, Brazil. Tel.: 55-19-3512 1115; Fax: 55-19-3512-1004; E-mail: andre.ambrosio@Inbio.cnpem.br. length GLS2. These structures explain these proteins' compromised ability to assemble into catalytically active supra-tetrameric filaments, as previously shown for GAC. Collectively, these results provide information about glutaminases that may aid in the design of isoform-specific glutaminase inhibitors.

Glutamine, the most abundant amino acid in human plasma and muscles (1), is consumed by rapidly proliferating tumor cells to meet their increased energy and biosynthetic precursor demands $(2,3)$. The enzyme glutaminase converts glutamine into glutamate, which is further catabolized to produce ATP, nucleotides, amino acids, lipids, and glutathione. In this regard, glutaminase is a well established target for the inhibition of cell transformation (4). Accordingly, several oncogenes and tumor suppressors have already been described to be involved in glutaminase-dependent glutamine breakdown (4). Notably, c-Myc stimulates glutamine uptake and degradation by GLS (specifically the product of the GLS gene) to sustain cellular viability and Krebs cycle anaplerosis (5). Similarly, nuclear factor $-\kappa \mathrm{B}(\mathrm{NF}-\kappa \mathrm{B})$ enhances glutamine metabolism by decreasing the expression of miR-23a, which targets the GLS mRNA (6); Rho GTPases, ubiquitin ligase anaphasepromoting complex/cyclosome (APC/C)-Cdh1, and c-Jun also regulate glutamine metabolism by acting on GLS and consequently supporting cancer growth (7-9). However, a second gene encodes another glutaminase enzyme, named GLS2. In contrast to GLS, GLS2 is regulated by the tumor suppressor p53 and has tumor suppressor features toward gliomas, glioblastomas, lung cancer, and hepatocarcinomas (10-14).

The existence of multiple glutaminases in mammals was first reported by Hans Krebs (15), on the basis of the detection of tissue-specific kinetic parameters and their susceptibility to inhibition by their catalytic products, when he probed the conversion of glutamine into glutamate in tissue extracts. In addition to being expressed by two different genes, at least four glutaminase isoforms have been described in mammals. The kidney-type isoforms, kidney-type glutaminase $(\mathrm{KGA})^{5}$ and

${ }^{5}$ The abbreviations used are: KGA, kidney-type glutaminase; LGA, liver-type glutaminase; GAB, glutaminase B; ANK, ankyrin; STAS, sulfate transporter and anti- $\sigma$ factor antagonist; $\mathrm{EH}$, Eps 15 homology; SAD, single-wavelength anomalous dispersion; r.m.s., root mean square; BPTES, (bis-2[5-phenylac- 


\section{The multidomain architecture of human glutaminases}

glutaminase $\mathrm{C}$ (GAC), are generated by alternative splicing of the GLS gene (2q32.2). Both isoforms are activated by inorganic phosphate and inhibited by glutamate $(16-18)$. In contrast, the liver-type isozymes, liver-type glutaminase (LGA) and glutaminase B (GAB), originate from the GLS2 gene (12q13.3) through the use of alternative transcription initiation sites (19). The recombinant construct that spans a common region between the GLS2 isoforms responds poorly to phosphate (20) and is not inhibited by glutamate $(19,21)$.

Although both the kidney isozymes and GAB are expected to be localized in the mitochondrial matrix because of the transit peptide sequences at their $\mathrm{N}$ termini, KGA and LGA can also localize to the cytosol and nuclei $(20,22)$. However, GAC has been shown to be exclusively located in the mitochondrion (20). Moreover, GAC provides key growth advantages to cancer cells (20). KGA, LGA, and GAB share a glutaminase domain that is well conserved in sequence and structurally similar to bacterial glutaminases, and it is flanked by a long N-terminal domain folded in an EF-hand-like four-helix bundle and a C-terminal domain with three putative ANK repeats (20). In contrast, $\mathrm{GAC}$ has a shorter, 48-amino acid-long $\mathrm{C}$ terminus with no canonical motif or domain. GAC is also unique because it assembles into highly active, long double-stranded helical filaments in the presence of inorganic phosphate, whereas KGA forms shorter and less active structures under the same conditions (23).

Intrigued by the diversity in numbers, architecture, mechanism of activation, and enzymatic capabilities of the human glutaminases, we felt motivated to investigate the origin, evolution, and possible functions of such complex features. First, by identifying homologous prokaryotic and eukaryotic sequences and building a phylogenetic tree, we propose that the multidomain architecture of the mammalian glutaminases GLS and GLS2 is a feature inherited from bacterial ancestors, probably simultaneously with the hosting of the proto-mitochondrion endosymbiont. From this phylogenetic tree, we also propose an evolutionary model wherein a GLS-like predecessor gene in tunicates gave rise to the currently known human isozymes through exon remodeling, gene duplication, and retrotransposition events. In addition, we solved high-resolution crystallographic structures of the C-terminal ANK repeats from both human KGA and GAB/LGA. These structures display a unique type of dimerization for ANK domains, governed by two short amino acid motifs that are highly conserved from bacteria to higher eukaryotes. Finally, we present the first $C$ terminus-containing crystallographic structure of human KGA, which explains its inability to assemble into the catalytically active supra-tetrameric filaments, as previously shown for GAC. A similar model for human GLS2 is also proposed on the basis of small-angle X-ray scattering data and cryo-electron microscopy. Collectively, these results contribute to the general knowledge on the many human glutaminase isoforms as well as explain the mechanistic diversity that poses challenges that still must be overcome to

etamido-1,2,4-thiadiazol-2-yl]ethyl sulfide; BIS-TRIS propane, 1,3-bis[tris(hydroxymethyl)methylamino]propane; ISAC, iterative stable alignment and clustering; PDB, Protein Data Bank; Rh, hydrodynamic radius. increase the chances of successfully inhibiting the enzyme in a clinical setting.

\section{Results \\ The multidomain origin of glutaminases}

An evolutionary analysis of 2,796 bacterial glutaminase protein sequences and 789 eukaryotic sequences selected from a BLAST search was performed using the glutaminase domain from human KGA ( $\mathrm{Ile}^{221}-\mathrm{Arg}^{544}$ ) as the query sequence ( $E$ value $\leq 0.0001)$. Particularly, no glutaminase homologs were identified in archaea. The bacterial sequence sizes presented three normal distributions. The first and major distribution ( $\sim 85 \%$ of the sequences) was centered at $313 \pm 10$ amino acids (Fig. $1 A$ ), thus suggesting that the proteins predominantly contained only the catalytic domain (24). The second distribution was smaller (10\% of the sequences) and centered at $429 \pm 16$ amino acids. Detailed analysis suggested that this group possesses a sulfate transporter and anti- $\sigma$ factor antagonist (STAS) domain located C-terminal to the glutaminase domain (Fig. $1 A$ ). Finally, 4\% (109) of bacterial glutaminases clustered in a third distribution centered at 613 amino acids. These sequences, in addition to the STAS domain, have an extra cyclic nucleotide-binding domain located $\mathrm{N}$-terminal to the glutaminase domain. Notably, three cyanobacteria sequences from this group possess a glutaminase domain flanked by an Eps15 homology-like domain (EH-like) at the $\mathrm{N}$ terminus and two clusters of ANK repeats at the $\mathrm{C}$ terminus (Fig. 1A). The Eps15 homology domain is a pair of EF-hand motifs that recognize and bind to proteins containing Asn-Pro-Phe (NPF) sequences (25). Aside from these three-domain cyanobacteria sequences, 17 proteo- and actinobacteria sequences situated between the second and third normal distributions (Fig. 1A, blue oval) also exhibit a glutaminase domain flanked $\mathrm{N}$-terminal by an $\mathrm{EH}$-like domain and C-terminal by only one cluster of ANK repeats.

Eukaryotic glutaminases, which primarily belong to the kingdoms Animalia and Fungi, are consistently longer and present a single Gaussian size distribution averaging 631 amino acids in length (mode at 615), with a skewed standard deviation of 45 amino acids toward shorter sequences and 26 amino acids toward longer sequences (Fig. 1B). The left-most end of the distribution contained the fungal glutaminases, which are 450 to 500 amino acids long and present a unique architecture, wherein the glutaminase domain is followed by a long $\mathrm{C}$ terminus (156 \pm 7 amino acids) with an unknown fold (Fig. 1B, pink bar). The remaining eukaryotic glutaminases that are longer than 500 amino acids in length mostly belong to the Animalia kingdom and have extended $\mathrm{N}$-terminal sequences of varying lengths (Fig. 1B). The $\mathrm{N}$-terminal region immediately adjacent to the glutaminase domain is more than $40 \%$ similar to the EF-hand-like four-helix bundle, which is structurally similar to the EH-like domain found in bacteria. Indeed, the X-ray structures of human GLS containing this domain have an EH-like structure (20).

Putative ANK repeats are predicted for about 550 of the longer eukaryotic glutaminases and are located C-terminal to the glutaminase domain with no exception. Another 76 sequences, 


\section{The multidomain architecture of human glutaminases}
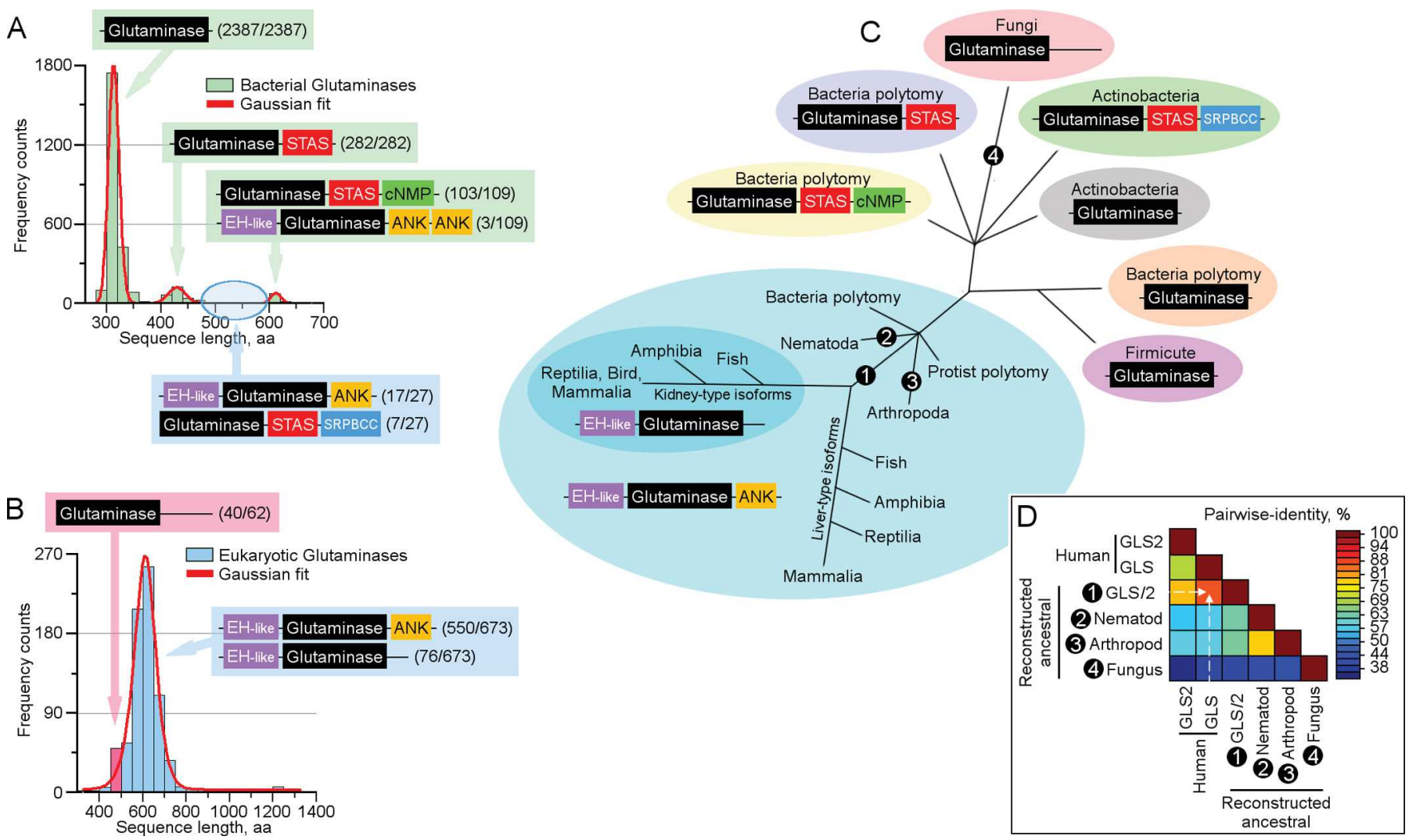

B

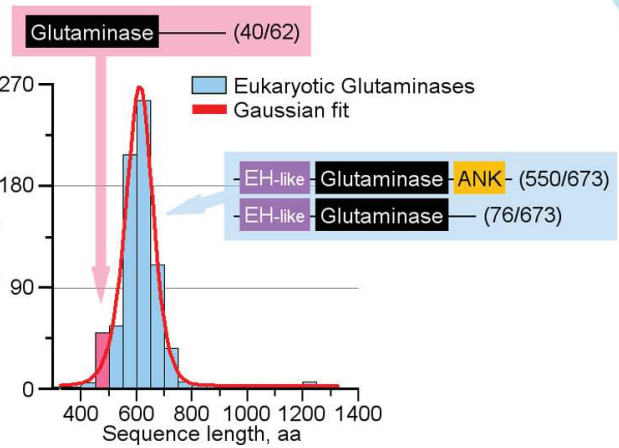

Figure 1. Sequence and architecture analysis of bacterial and eukaryotic glutaminases. The amino acid sequence corresponding to the glutaminase domain of the GLS gene (Ile ${ }^{221}-\mathrm{Arg}^{544}$ ) was used as input of blastp search against the non-redundant protein sequences (nr) database $(E$ value $\leq 0.0001)$. The sequences obtained were analyzed by number of amino acids ( $a a$ ); the normal distribution of the sequence length for bacterial and eukaryote glutaminases are, respectively, represented in $A$ and $B$, with the respective architectures indicated in rectangles; in parentheses, the number of sequences containing the corresponding architecture/the total number of sequences contained in the referred region of the distribution plot. $C$, cladogram based on architectural organization obtained from a maximum likelihood phylogenetic reconstruction approach. $D$, the generated phylogenetic tree and respective alignment were used to reconstruct ancestral protein sequences for specific nodes (ancestral chordates (1); nematodes (2); arthropodes (3); and fungi (4)) using maximum parsimony. The obtained ancestral sequences were aligned with the human GLS (KGA and GAC) and GLS2 (GAB and LGA) and the sequence similarity displayed as a heatmap of pairwise distances constructed in SDT using MUSCLE alignment. The obtained result suggests that GLS is the most primitive gene, which has been further duplicated to generate GLS2. cNMP, cyclic nucleotide-binding domain; SRPBCC, START/RHO $\alpha$ C/PITP/Bet v1/CoxG/CalC.

all of mammalian origin, have a shorter $\mathrm{C}$ terminus that closely resembles human GAC in sequence (Fig. $1 B$ ). Finally, a few glutaminase sequences ( 11 in total) belonging to the major haptophyte and heterokont lines of eukaryotes were identified. These sequences are much longer, ranging from 800 to 1250 amino acids in length, and the predicted architectures of some of them consist of two complete tandemly associated ANKcontaining glutaminases (data not shown).

To detect evolutionary relationships based on the architectural organization, we next reconstructed an unrooted cladogram using the analyzed sequences (Fig. 1C). The derived tree structure has a taxa organization similar to that found in rRNAbased phylogenetic trees (26). Many unresolved nodes (polytomy) were observed, particularly for the bacterial glutaminases. We believe that such observation stems from the fact that many bacterial species possibly have more than one glutaminase, often as a result of the combination of a single protein with a multidomain isozyme. Except for fungal glutaminases, which clustered closer to the bacterial homologs, the eukaryotic proteins had a better-resolved tree. Protists, nematodes, and arthropods form a polytomic group with chordates, as well as with ANK-containing proteo- and cyanobacteria; this grouping suggests that the appearance of this multidomain feature was an early event, concomitant with the symbiotic association related to the appearance of eukaryotes, because archaea does not carry any glutaminase-like coding gene. A subsequent lineage split linked to the appearance of multiple variations around the same basic architecture $(\mathrm{EH}$-like + glutaminase + ANK) suggests that the gene duplication event that produced the GLS and GLS2 genes and isoform differentiation (with the appearance of GAC-like isoforms; Fig. 1B, dark blue oval) appeared with chordates. However, interestingly, birds have completely lost the GLS2 gene.

Finally, based on a theoretical reconstruction of the ancestral glutaminases from each of the main eukaryotic branches (chordata, arthropods, nematodes, and fungi), the most primitive glutaminase acquired from a bacterial ancestor was most probably the kidney-type glutaminase (KGA-like), as shown in Fig. $1 D$. The general organization $\mathrm{EH}$-like + glutaminase $+\mathrm{ANK}$ is preserved in all four reconstructed ancestral sequences. Comparison of the sequence identity of human genes with the reconstructed common ancestor of GLS and GLS2 from Gnathostomata suggested that GLS was restrained during evolution to maintain the same function, whereas GLS2 exhibited more changes, probably acquiring new functions and/or regulatory mechanisms. 


\section{The multidomain architecture of human glutaminases}

\section{The origin of glutaminase isoforms}

Having established a plausible origin for the multidomain architecture of the glutaminases, we next asked how the different variants of the enzyme, currently observed in humans, might have evolved. We first performed a "top-down" search for glutaminase genes in phylum Chordata using the complete genomic sequence of the human GLS and GLS2 genes as templates. Second, we identified regions homologous to exon 14 of GLS (after which the GLS splicing event occurs) and exon 15 (the "GAC exon").

In the lower chordates, we verified that the genome of the tunicate sea squirt (27) (Ciona intestinalis) has a single GLS-like gene containing 12 exons. A region similar to human exon 14. (70\% identity, red bar in the tunicate branch, Fig. $2 A$ ) is inserted in exon 11. The Cephalochordate amphioxus (28) (Branchiostoma floridae) also has a single glutaminase gene, which, interestingly, has only two exons. In this gene, the region homologous to the human exon 14 is appropriately located at the $3^{\prime}$ boundary of exon 1 ; however, no homology to the GAC exon was identified in the downstream sequence. A gene duplication event was observed further upstream in lampreys (29) (Pekinsus marinus, Hyperortia), which generated distinct sequences related to the human GLS and GLS2 genes.

Next, the Chondrichthyes Callorhinchus milii (elephant shark (30)) also has two glutaminases that are phylogenetically related to the GLS and GLS2 genes without annotated splicing regulation. However, in the GLS gene, a region homologous to the human GAC exon is for the first time observed and located downstream of an exon 14-equivalent sequence, thereby suggesting an origin for the splicing variant GAC. Zebrafish (Danio rerio (31)) and other fish species possess 5 glutaminase genes, thus suggesting subsequent autapomorphic duplication events for both GLS and GLS2. Interestingly, the GAC isoform was maintained in both copies of the GLS gene, thus supporting the hypothesis that the GAC exon appeared before this duplication; a new GLS-like (GLSL) sequence was identified in species within this branch, such as zebrafish, elephant shark, and others.

Of note, the amphibian Xenopus tropicalis (Western clawed frog (32)), with only one copy of both GLS and GLS2, points to a compaction of the GLS2 introns and exons against the spread of the GLS across a larger genomic region. Finally, the human glutaminase gene structures retained the same architecture observed in the amphibian genes, although the sequence lengths were smaller.

The identification of several transposable elements such as Alu and L2 (Fig. 2B), within the human GLS intron 15, strongly suggests that the insertion of the GAC exon was due to an early retrotransposition event; however, no consensus matching elements were found in the rapid evolving intron 14 . Nevertheless, a thorough tblastn analysis failed to identify a region homologous to the GAC exon (exon 15) within the human genome, preventing us from proposing an original location for this sequence.

\section{Crystal structures of the human glutaminase ankyrin repeats}

We next determined the crystal structures of the ANK-containing C-terminal regions of both human KGA (KGA.ANK: $\mathrm{Val}^{551}-\mathrm{Leu}^{669}$ ) and GLS2 (GLS2.ANK: Lys ${ }^{485}-\mathrm{Val}^{602}$ ). Both proteins were subjected to limited proteolysis with trypsin (for KGA.ANK) or chymotrypsin (for GLS2.ANK) during purification to remove the likely intrinsically flexible regions and obtain well diffracting crystals. X-ray diffraction datasets were obtained for KGA.ANK crystals belonging to two different space groups, namely the tetragonal $\mathrm{P}_{3} 2_{1} 2$ and a monoclinic $\mathrm{P} 12{ }_{1}$ 1. Sulfur single-wavelength anomalous dispersion (SAD) phasing was used to produce a higher resolution molecular model (at $1.41 \AA$ maximum) from the tetragonal crystals. The obtained structure was then used as a search model for molecular replacement of the monoclinic crystals, which diffracted up to 1.74- $\AA$ maximum resolution. Finally, the structure, which was collected at 2.55 - $\AA$ maximum resolution, of the GLS2.ANK hexagonal crystals (space group $\mathrm{P}_{5}$ ) was solved by molecular replacement using the KGA.ANK structure. The statistics of the data collection, processing, phasing, and model refinement data for all the structures are shown in Table 1. Because of the high structural similarity observed for both KGA.ANK structures (backbone r.m.s. deviations of $0.4 \AA$ ), only the higher resolution model was used for the subsequent detailed analysis and comparison to the GLS2.ANK structure.

Overall, the C-terminal domains of KGA and GLS2 each contain three ANK repeats (labeled ANK1 to ANK3) and are very similar, both in sequence composition (80\% identical) and overall structure (r.m.s. deviation of $0.5 \AA$ over 89 equivalent $\mathrm{C} \alpha$ positions; Fig. $3 A$ ). The largest structural variation (a shift between 1.3 and $1.8 \AA$ of the $\mathrm{C} \alpha$ atom positions) occurs in the $\beta$-hairpin that links ANK1 to ANK2 ( $\beta$-hairpin 2$)$, whereas the minimal deviations $(\sim 0.1 \AA)$ are observed in the inner and outer $\alpha$-helices of ANK2. The primary sequences of ANK1 and ANK3 repeats in both KGA and GLS2 diverge from the canonical ANK repeats at the TPLH tetrapeptide motif, which is located at the beginning of the inner $\alpha$-helices and is responsible for the stabilization of ANK repeats through reciprocal hydrogen bonding between the threonine hydroxyl and histidine imidazole groups $(33,34)$ (Fig. 3B). The ANK1 inner helix of both KGA and GLS2 is a half-turn longer and lacks the $\beta 1$ turn compared with the typical inner helix observed in ANK repeats (Fig. $3 B$ ), whereas in the ANK3 inner helix, the histidine is replaced with an aspartate, thus preventing the formation of the conserved hydroxyl-imidazole hydrogen bond. Moreover, in both structures, ANK2 contains an extra residue, a surfaceexposed lysine (Lys ${ }^{611}$ at KGA and Lys ${ }^{543}$ at GLS2, indicated by a plus sign in Fig. $3 B$ ), at the $C$ terminus of the outer helix. Finally, the GLS2 ANK3 outer helix is one turn longer than the canonical ANK repeats (Fig. 3B).

\section{Glutaminase ankyrin repeats assemble into atypical dimers}

A search for the biologically relevant assembly of the KGA and GLS2 ANK domains was performed using the PISA (protein interfaces, surfaces and assemblies) server (35). The program identified a thermodynamically stable interface involving a crystallographic homodimer, with a solvation free energy gain of $-5.4 \mathrm{kcal} / \mathrm{M}$ upon formation (Fig. $3 \mathrm{C}$ ). The identified interface occludes an area of $800 \AA^{2}$ and corresponds to a symmetric groove-to-groove interaction in both structures. Twelve hydrogen bonds and 12 salt bridges are formed between the short loops present in the $\beta$-hairpins 1 (linking ANK1 to ANK2) and 


\section{The multidomain architecture of human glutaminases}

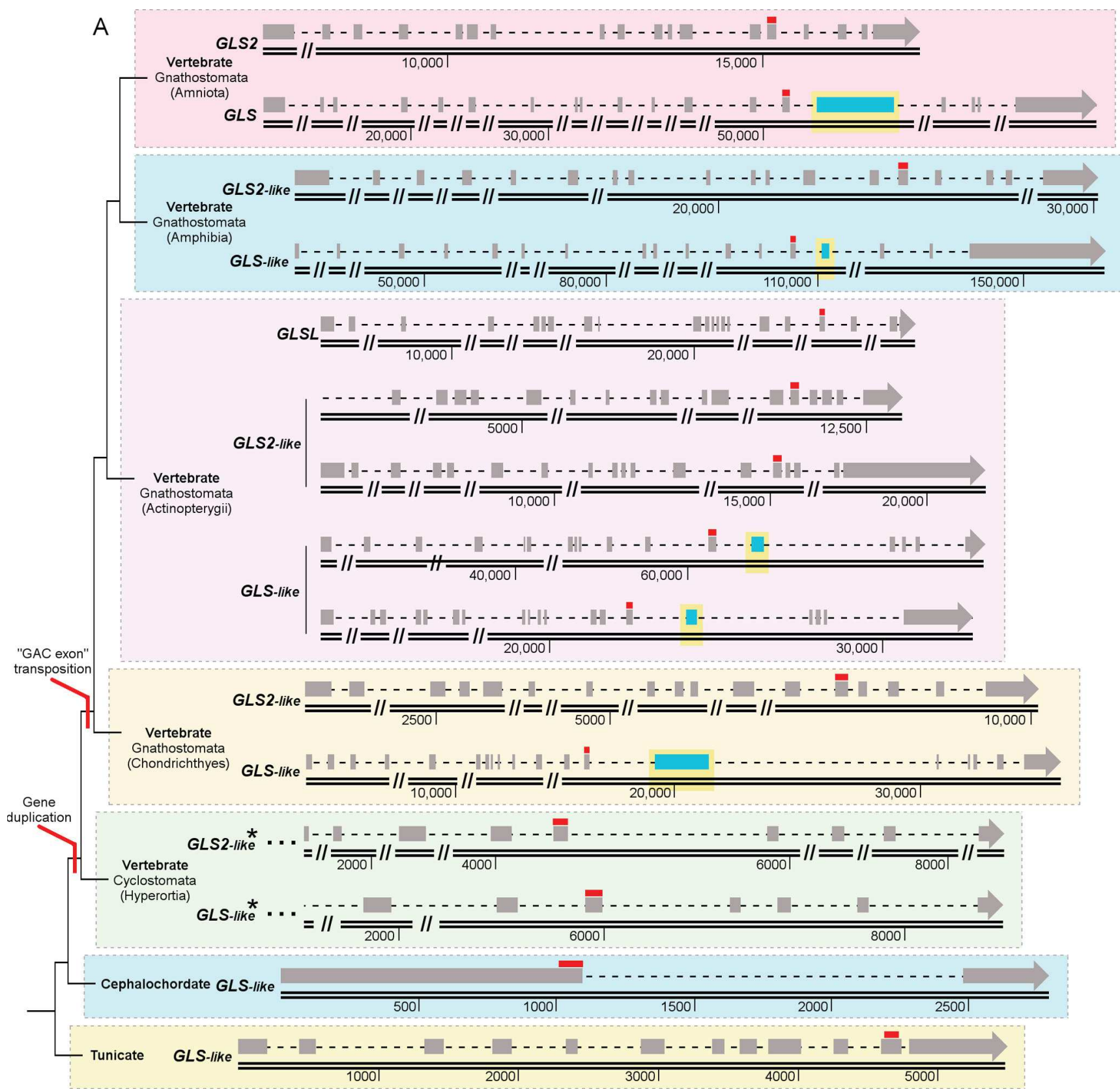

B

Human GLS (2q32.2)

CR1 MER1 L2 Alu $\square$ Mir/Other

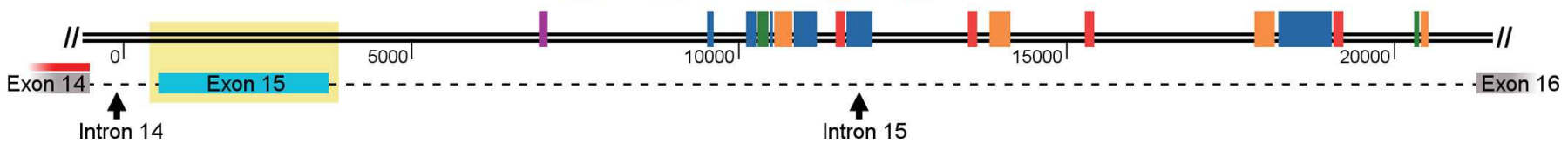

Figure 2. Evolution of glutaminase intron-exon structure. $A$, protein sequence corresponding to human GLS exon 14 was used as a query of translated blast (tblastn) searches against available genomes from C. intestinalis (Tunicate), B. floridae (Cephalochordate), P. marinus (Cyclostomata), C. milii (Chondrichthyes), D. rerio (Actinopterygii), and X. tropicalis (Amphibia). After an initial Reciprocal Best Hit region was found, the correct position of the exon was determined by pairwise LALIGN between sequences. Region downstream genomic sequence homologous to exon 14 were also evaluated by LALIGN against human GAC-exclusive exon (exon 15). As both P. marinus glutaminases are incomplete, available exons were found in contig using LALIGN approach. The human genes are represented at the top branch (Amniota). The thin red bars represent the homologous region to the GLS exon 14 and the light blue boxes indicate homologous regions to the exon 15 of human GLS. The introns, represented as dashed lines, are not drawn to scale and the omitted sections are indicated by two bars $(\|)$. The asterisk $(*)$ indicates that the deposited sequences are incomplete. $B$, a search for retrotransposition evidences in the genomic region comprehending exon 15 and introns 14 and 15 of human GLS using TranspoGene resulted in the identification of various transposable elements in the intron 15; however, no consensus matching elements were found in the intron 14. 
The multidomain architecture of human glutaminases

Table 1

X-ray crystallography data collection parameters and structure refinement statistics

Data for the outer shell are shown in parentheses.

\begin{tabular}{|c|c|c|c|c|}
\hline \multicolumn{5}{|l|}{ Data collection and processing } \\
\hline Beamline & $12-2$ at SSRL, USA & $12-2$ at SSRL, USA & $12-2$ at SSRL, USA & I03 at DLS, UK \\
\hline Wavelength $(\AA)$ & 0.9795 & 0.9795 & 0.9795 & 0.9762 \\
\hline Space group & P 43212 & P 1211 & P 65 & P 42212 \\
\hline Cell parameters $(\AA)$ & $a=b=75.3, c=88.3$ & $a=76.5, b=47.2, c=115.7\left(\beta=90.1^{\circ}\right)$ & $a=b=85.2, c=336.8$ & $a=b=144.1, c=615.2$ \\
\hline Resolution range (§) & $75.0-1.42(1.45-1.42)$ & $64.0-1.72(1.75-1.72)$ & $84.0-2.55(2.64-2.55)$ & $50.0-3.6(3.67-3.60)$ \\
\hline Unique reflections & $48,262(2,342)$ & $82,659(4,303)$ & $45,005(4,413)$ & $76,934(4,463)$ \\
\hline Multiplicity & $22.7(23.2)$ & $6.4(6.3)$ & $8.1(8.1)$ & $23.4(20.8)$ \\
\hline$R_{\mathrm{pim}}(\%)$ & $2.6(30.9)$ & $2.4(31.8)$ & $3.5(25.2)$ & $7.4(49.4)$ \\
\hline CC $(1 / 2)$ & $0.994(0.441)$ & $0.999(0.902)$ & $0.999(0.860)$ & $0.998(0.716)$ \\
\hline Completeness (\%) & $100(100)$ & $94.1(92.1)$ & $99.9(99.8)$ & $100(100)$ \\
\hline$\langle I / \sigma(I)\rangle$ & $17.1(2.9)$ & $15.7(2.1)$ & $14.1(3.4)$ & $8.8(1.9)$ \\
\hline Average mosaicity $\left(^{\circ}\right)$ & 0.62 & 0.55 & 0.49 & 0.30 \\
\hline Wilson B-factor $\left(\AA^{2}\right)$ & 13.6 & 25.7 & 48.5 & 104.6 \\
\hline Monomers/AU & 2 & $4^{*}$ & 10 & 5 \\
\hline Solvent content (\%) & 46.7 & $36.4 \%$ & 53.0 & 77.1 \\
\hline Matthews coefficient $\left(\mathrm{A}^{3} \mathrm{Da}^{-1}\right)$ & 2.32 & $1.93^{a}$ & 2.62 & 5.37 \\
\hline \multicolumn{5}{|l|}{ Model refinement } \\
\hline Resolution range $(\AA)$ & $57.3-1.42$ & $64.0-1.72$ & $73.8-2.55$ & $50.0-3.6$ \\
\hline Test set reflections (\%) & $2500(5.2)$ & $4285(5.2)$ & $2366(5.3)$ & $7160(5.0)$ \\
\hline$R_{\text {factor }} / R_{\text {free }}(\%)$ & $14.4 / 17.9$ & $18.3 / 22.2$ & $21.8 / 25.7$ & $27.4 / 31.2$ \\
\hline Clashscore & 2 & 2 & 5 & 3 \\
\hline Side chain outliers (\%) & 0.6 & 0.7 & 2.4 & 2.6 \\
\hline RSRZ outliers (\%) & 1.6 & 0.6 & 2.8 & 5.7 \\
\hline Average $B$, all atoms $\left(\AA^{2}\right)$ & 22.0 & 34.0 & 53.0 & 137.0 \\
\hline Number of protein atoms & 1,506 & 2,943 & 6,860 & 18,905 \\
\hline Solvent molecules & 285 & 640 & 110 & \\
\hline Inorganic atoms & $1 \mathrm{Cl}^{-}, 3 \mathrm{Na}^{+}$ & $6 \mathrm{Na}^{+}$ & & \\
\hline Ligand molecules & & & & 3 BPTES \\
\hline \multicolumn{5}{|l|}{$\begin{array}{l}\text { R.m.s. deviations from standard } \\
\text { geometry }\end{array}$} \\
\hline Bond length $(\AA ̊)$ & 0.015 & 0.019 & 0.002 & 0.003 \\
\hline Bond angles $\left({ }^{\circ}\right)$ & 1.313 & 1.454 & 0.479 & 0.566 \\
\hline \multicolumn{5}{|l|}{ Ramachandran plot (\%) } \\
\hline Most favorable & 98.0 & 98.6 & 95.9 & 87.5 \\
\hline Outliers & 0 & 0 & 0.2 & 2.1 \\
\hline PDB ID & $5 \mathrm{u} 0 \mathrm{i}$ & $5 \mathrm{u} 0 \mathrm{j}$ & $5 \mathrm{u} 0 \mathrm{k}$ & 5uqe \\
\hline
\end{tabular}

2 (linking ANK2 to ANK3, Fig. 3B) in chain A with their respective equivalents in chain B (Fig. 3C, left panel, for $\beta$-hairpin 1 loop interactions and right panel for $\beta$-hairpin 2 loop interactions). The short loops of $\beta$-hairpins 1 and 2 contain the motifs Asp-Tyr-Asp (DYD, residues 583-585 in KGA and 516-518 in GLS2) and Asp-Arg-Trp (DRW, residues 617-619 in KGA and $550-552$ in GLS2), respectively (Fig. 3C). Despite the overall relatively low sequence identity of the eukaryotic and bacterial glutaminase ANK repeats, both the DYD and DRW motifs are highly conserved (Fig. 3, $D$ and $E$, respectively). Finally, additional polar interactions are observed between the $\beta$-hairpin 1 loop and the ANK3 inner helix and between the $\beta$-hairpin 2 loop and the ANK2 inner helix, complementing the identified symmetrical interface (data not shown).

\section{Crystal structure of full-length human KGA}

In addition to the determination of the crystal structures of the isolated C-terminal ANK dimers, we also solved the novel crystal structure of KGA containing the $\mathrm{C}$ terminus, which was bound to the inhibitor bis-2[5-phenylacetamido-1,2,4-thiadiazol-2-yl] ethyl sulfide (BPTES) (36). The diffraction dataset was collected at a 3.6- $\AA$ maximum resolution (space group $\mathrm{P}_{2} 2_{1} 2$ ) with lengthy cell parameters and a high solvent content of $\sim 78 \%$ (Table 1). Phasing was achieved by molecular replacement using the coordinates of the previously solved N-terminal and glutaminase domains from GAC bound to BPTES (PDB code 4jkt) and the KGA.ANK dimer described here as search models. The $\mathrm{P}_{2} 2_{1} 2$ asymmetric unit contains five KGA monomers; accordingly, one canonical tetramer (a dimer of dimers) is formed within the asymmetric unit by four monomers and, the fifth monomer is related to another tetramer by the crystal 2-fold screw axis. The final model obtained (Fig. $4 A$ ) was refined to $R_{\text {factor }}$ and $R_{\text {free }}$ of 27.3 and $31.8 \%$, respectively.

The ANK dimers in the KGA structure (green surface in Fig. $4 B$ ) are spatially located between the N-terminal EF-hand-like domains (blue surfaces in Fig. 4B). Notably, both ANK dimers of a tetramer lie on the same side of a sectional plane defined by the two longest axes of the protein (Fig. $4 B$ ), breaking the previously established 2-fold dihedral symmetry of the glutaminase structures lacking the $\mathrm{C}$ terminus (20).

The low-resolution model did not allow us to provide a detailed description of the side chain interactions between the ANK dimers and the N-terminal domain. However, the close contact between the ANK1 outer helix of chain A with the EFhand-like domain helix $\mathrm{H} 1$ of chain B is unmistakable (Fig. 4C). The interface contains large, exposed polar residues, such as glutamic acid and arginine, which are likely to be responsible for the contact. An equivalent arrangement was also observed for the ANK1 outer helix of chain $C$ with the EF-hand-like domain helix $\mathrm{H} 1$ of chain $\mathrm{D}$ (data not shown). The majority of the C-terminal region of KGA adjacent to the ANK repeats (residues $\mathrm{Thr}^{647}$-Leu ${ }^{669}$ ) is likely heterogeneous in conforma- 


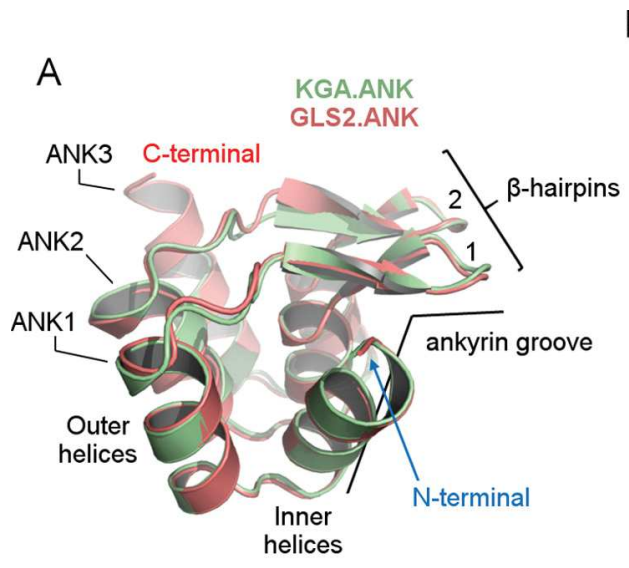

B

Consensus ankyrin: $1-\stackrel{-G-T P L H \Psi A---G-1 \text { WV }-\Psi L L--G . A-V-a k---}{-G}-33$

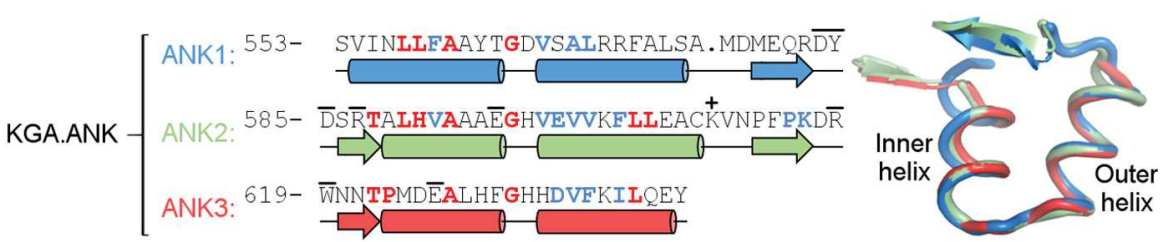

GLS2.ANK-

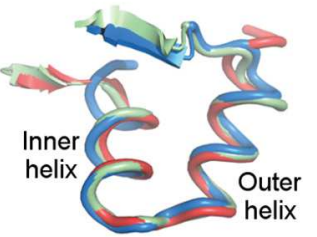

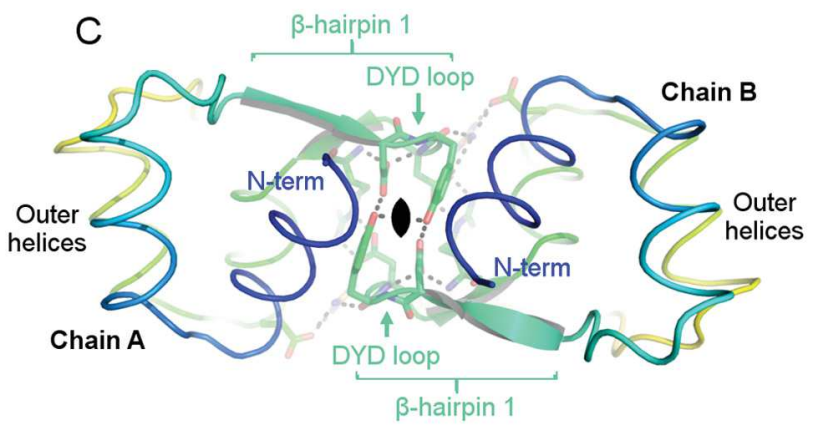
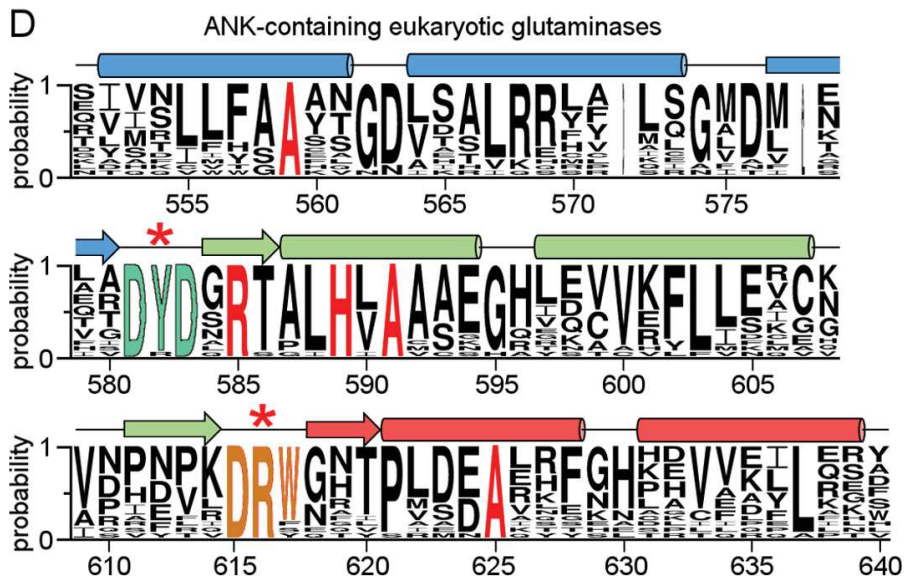

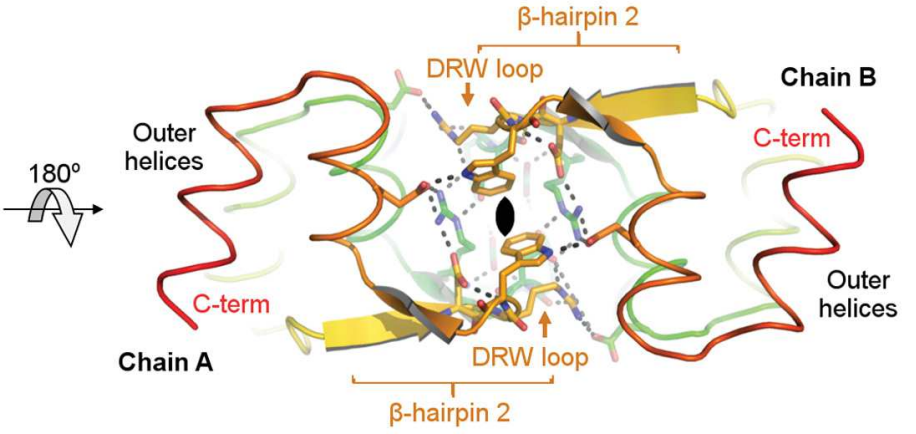

E
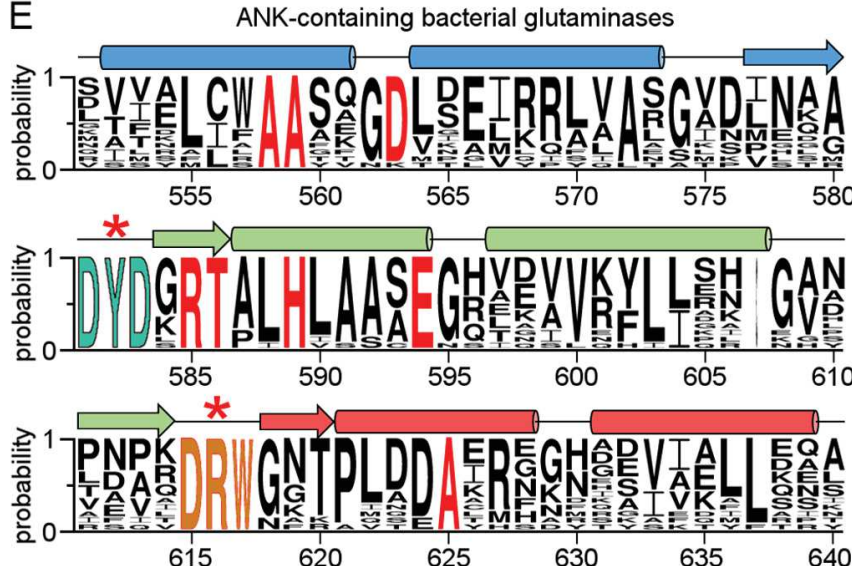

Figure 3. Overall structural features of ANK domain of glutaminases. $A$, schematic representation of three ANK repeats (ANK1 to ANK3) present as a C-terminal domain of KGA and GLS2. Both ANK repeats are very similar in sequence as well as in the overall structure. B, alignment of the glutaminase ANK repeats and the consensus sequence (shown on top), proposed in Ref. 39. Highly conserved residues are capitalized and in red, semiconserved residues are colored cyan and not capitalized. Residues involved in the dimer interface are indicated by a bar. ANK2 in both KGA and GLS2 contains an extra surface-exposed lysine, which is indicated by the + signal. On the right, the superposition of ANK1, ANK2, and ANK3 is represented. C, dimer interface and associated interaction of ANK repeats. The side chains of the motifs DYD (left) and DRW (right) are represented in sticks. D, representation of sequence conservation of glutaminases ANK from eukaryotes and $E$, bacteria. The size of the letters is proportional to the degree of conservation of residues. The motifs DYD and DRW are highlighted. The residues in red shows the $100 \%$ conservation throughout the alignment. Residues are numbered according to human KGA.

tion and therefore could not be modeled. According to secondary structure predictions by the JPred4 server (37), this region is mostly unstructured. This information, added to the fact that such region is present in a KEN box involved on KGA degradation (8), suggest that this segment is likely functionally independent from the ankyrin domain.

As shown in our previous study (23), the phosphate-dependent enzymatic activity of the GLS isoforms is directly related to their ability of self-assembling into supra-tetrameric helical filaments; GAC is the most active isoform and forms longer filaments. Moreover, we previously demonstrated that this assembly was generated by end-to-end associations via the $\mathrm{N}$-terminal domains; the KGA assembly was always shorter, although it formed the same structure. Based on the KGA crystal structure presented here, we hypothesized that the ANK repeats located between the $\mathrm{N}$-terminal domains prevent KGA from forming longer higher active filaments due to the fact that it destabilizes the polymerization. More specifically, the ANK dimers limit the association of the KGA tetramers into long polymers (23) because they limit the formation and availability of the filamentation interface (Fig. 4D). This interface is the groove region by which the single strand filaments of the GAC 

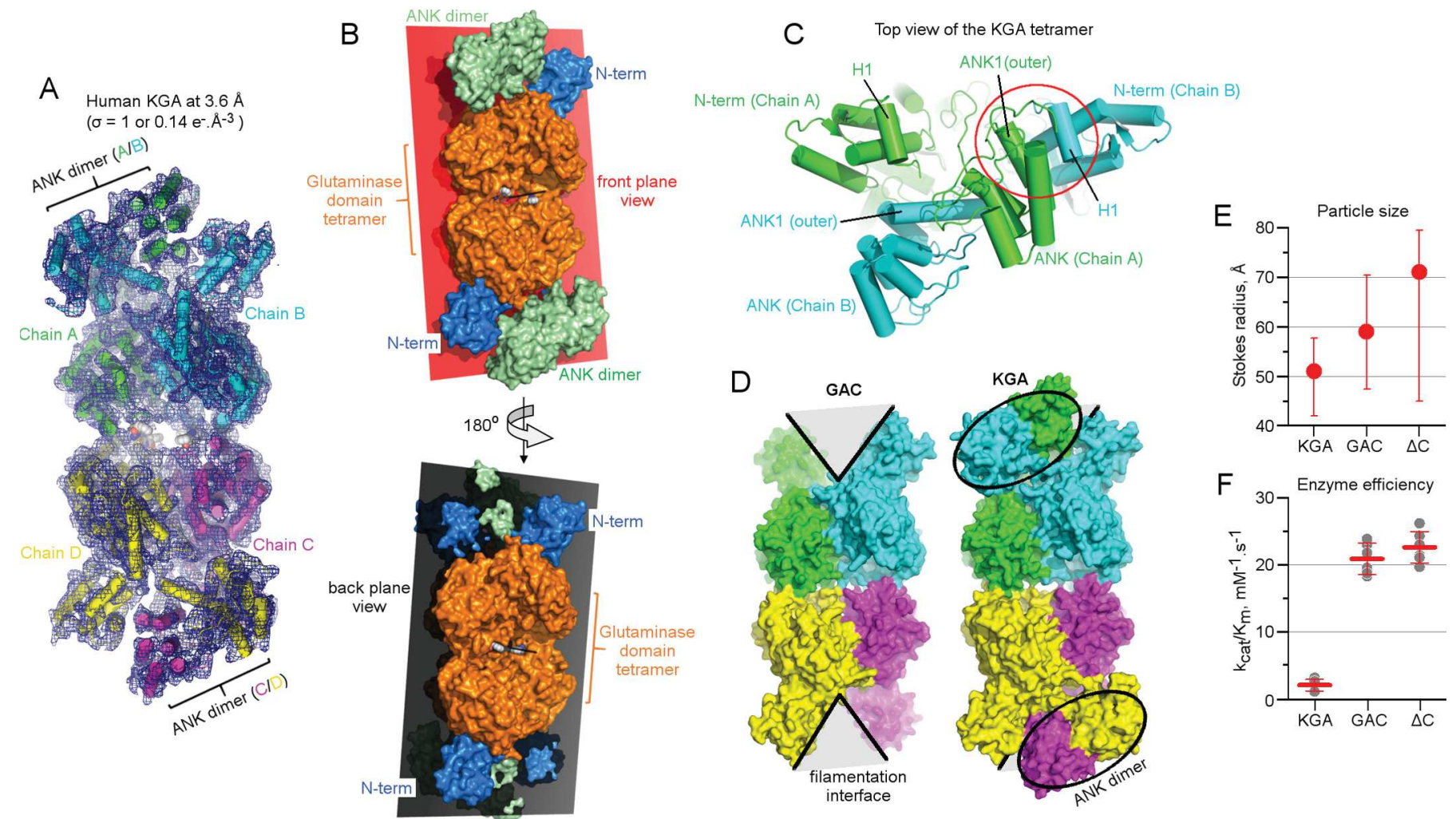

Figure 4. Multidomain structure of KGA and biophysical characterization of KGA, GAC, and $\triangle \mathrm{C}$. A, electron density and final model for the complete tetramer of KGA. B, planar representation, dividing the tetramer into front and back halves to show the position of two ANK dimers at the same side of the plane. $C$, upper view of the tetramer, indicating the close contact between the ANK1 outer helix and the helix $\mathrm{H} 1$ of the N-terminal EF-hand like domain. D, the filament interface between two N-terminal domains (region delimited by gray), and by which the single strand polymer of GAC (PDB code 4jkt) grows (23), is occluded in KGA because of the presence of the ankyrin dimers. $E$, the Stokes radii calculated from the size exclusion chromatographic profiles of KGA, GAC, and $\triangle C$ (KGA lacking the ANK repeats), indicating that ANK repeats prevent the self-assembly of glutaminases into the higher supra-tetrameric filament forms. $F$, the comparative enzymatic efficiency of KGA, GAC, and $\Delta C$ toward glutamine in the presence of $20 \mathrm{~mm}$ phosphate. The lack of ANK repeats enhances the catalytic efficiency of KGA. Red lines indicate mean \pm S.D.

isoform grows indefinitely, via end to end interaction between pairs of N-terminal domains (23).

To further confirm this hypothesis, we generated a C terminally truncated GLS construct containing the common sequence between KGA and GAC ( $\mathrm{N}$ terminus and glutaminase domains, called $\Delta \mathrm{C}$ ), but lacking the ANK repeats. Accordingly, the construct had a larger Stokes radius in comparison to KGA and GAC and was more heterogeneous in size (Fig. 4E). Moreover, as expected, the $\Delta \mathrm{C}$ construct was as active as GAC, possibly due to its increased ability to form extended filaments (Fig. 4F).

\section{Low resolution structure of GLS2}

Last, the availability of the crystal structure of individual domains of GAB/LGA, such as the C-terminal ANK dimers reported here and the glutaminase domain tetramer (PDB code 4bqm), allowed for a proposition of the full-length structure based on small-angle X-ray scattering data (Fig. 5, $A$ and $B$ ) for the multidomain portion common to both isoforms. The C-terminal ANK domains are expected to be spatially located between the $\mathrm{N}$-terminal domains, in an organization similar to that observed for KGA. Consequently, this protein is also expected not to assemble in filament-like higher order oligomers, being stable at the tetramer form. This has been previously observed by our group (23) and is here corroborated by measurements on cryo-electron microscopy images (Fig. 5C).

\section{Discussion}

The human genome has two copies of glutaminase-coding genes, which are known to produce at least four isoforms through alternative splicing or transcription at alternative initiation sites (4). Genetic evolutionary models often predict an increase in the gene copy number prior to the specialization or gain of new functions, with a momentary intermediate state of specialization with an overlap of functions (38). In addition, this apparent redundancy in glutaminase isoforms can be explained by differential tissue expression patterns, as well as the cell proliferation state. In this regard, KGA is expressed in kidney tubule epithelial cells, in which ammonia production is key to renal acid-base regulation (16); LGA is expressed in periportal hepatocytes, where it participates in urea synthesis (17). In addition, although GAC meets the glutamine-dependent metabolic demands of several types of cancer (20), GAB has tumorsuppressing activity in hepatocarcinomas and gliomas (40).

Despite this functional diversity, the human glutaminase isoforms converge into a conserved multidomain structure. Based on a combination of computational predictions and experimental evidence mainly produced by X-ray crystallography studies, we found that all four isoforms contain an N-terminal EF-hand-like domain, followed by a glutaminase domain in the middle and three ANK repeats at the $C$ terminus. The only exception is GAC, in which the $C$ terminus is a short 


\section{The multidomain architecture of human glutaminases}
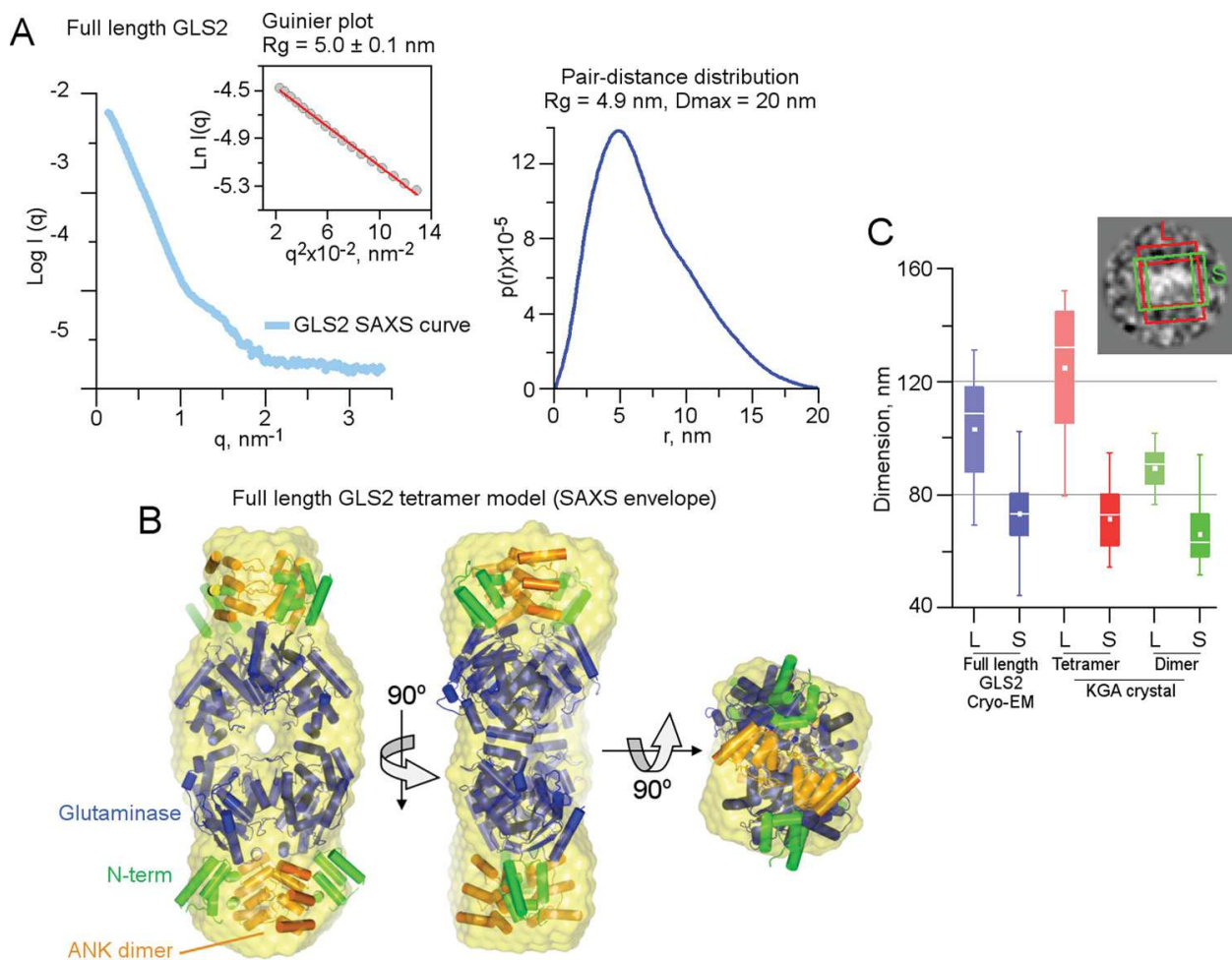

Figure 5. Low-resolution solution model for full-length GLS2 (GAB/LGA). Intensity (left panel) and pair-distance (right panel) distribution functions, obtained for GAB/LGA subject to SAXS experiments. B, orthogonal views of the superposition between the SAXS envelope and the collection of X-ray crystal structures from GLS2 glutaminase domain (PDB code 4BOM), N-terminal portion of human GLS (PDB code 3CZD) and GAB/LGA.ANK. C, box plot of the two perpendicular dimensions for GAB/LGA, large $(L)$ and short $(S)$ as taken from the cryo-EM micrographs (inset). KGA dimer and tetramer crystal structures projections were used as a reference for the dimensions of these two oligomeric states.

unstructured region, because of alternative splicing of the GLS gene.

In this work, the multidomain architecture was shown to be shared by all chordates, including fishes, reptiles, birds, and amphibians, as well as by arthropods and nematodes. By surveying the database-deposited glutaminase protein sequences, we observed similar organizational characteristics in free-living proteo- and cyanobacteria, but not fungi. From our data, we propose that the multidomain glutaminase structure has a very ancient origin. In addition, we verified that multiple GLS genes and isoforms are present in a wide range of vertebrates. By further analyzing the genomes of representative species of the phylum Chordata, we were able to identify early events of exon repositioning among tunicates and cephalochordates, followed by gene duplication in Hyperoartia and exon retrotransposition in Chondrichthyes, concomitant with the change from a simple kidney structure pronephros to a more complex mesonephros with tubules (41). Together, all these features are likely the basis of the isozyme diversity observed in vertebrates. We also identified a glutaminase ancestor that was more similar to the human kidney-type glutaminase and gave rise to the liver-type glutaminase, whereas the appearance of GAC-like glutaminases, with shorter $\mathrm{C}$ termini, was a late event in glutaminase evolution. GAC is the most active isoform compared with KGA and LGA, a feature linked to its capacity to assemble into long filament-like superstructures (23). In the present study, we found that this feature is possible only because GAC lacks the original C-terminal bulky ANK repeats of parental KGA, because the $\Delta C$-terminal construct assembles in longer fila- ments and is as active as GAC. Therefore, we propose that filament formation is a gain-of-function characteristic of vertebrate glutaminases, which has been positively selected to create a more active enzyme due to the substrate channeling effect.

Our group and others have previously published the structure of the N-terminal EF-hand-like and glutaminase domains of GLS $(20,42)$, but the structure of the C-terminal ANK repeats remained unsolved. Here, we provide novel crystal structures for the ANK domains of KGA and GLS2, which surprisingly form an atypical dimer. ANK repeats usually mediate the interaction of a protein with a different partner. However, KGA.ANK and GLS2.ANK mediated the formation of homooligomers, a rare feature. A survey of structures in the Protein Data Bank revealed 68 unique crystal structures of ANK-containing proteins, containing between 2 to 24 ANK repeats (supplemental Table S1). Of these crystal structures, only 5 displayed an ANK-to-ANK association (supplemental Fig. S1). However, none contained an interface that resembles the glutaminase ANK dimer (contact between the DYD and DRW motifs). Therefore, we propose that the ANK dimer association described here is structurally unique to glutaminases and was selected as a conserved feature throughout glutaminase evolution. The explanation for this positive selection remains elusive.

The short regions located immediately after the ANK repeats in KGA and GLS2 (KEN and ESMV motif, respectively) are involved in E3 ubiquitin ligase-dependent degradation (8) and direct interactions with PDZ domain-containing proteins (43), respectively. An analysis of protein complexes including ANKcontaining proteins and their interaction partners $(44-47)$ 


\section{The multidomain architecture of human glutaminases}

showed that most of the contacts necessary for ANK-to-ANK interaction involves the ANK grove (the concave surface). Although most of the known cases involve the concave surface, some ANK repeats mediate protein-protein contacts through the convex face. One example is the human oncoprotein g-ankyrin, which was crystallized in complex with an antibody fragment. In this structure, the interaction occurred through the outer $\alpha$-helices of the ANK4-ANK6 repeats (48). The vaccinia virus K1 protein consists entirely of ANK repeats that are involved in interactions mediated by the convex surface (49). In addition, the VPS9-domain ANK repeat protein binds to Rab32 through the convex side of its ANK repeat (50).

In this regard, although the concave faces of the ANK repeats of KGA and GLS2 make contacts within the glutaminase, we predict that the ANK repeats may still mediate protein-protein interactions through the convex surface. Recently, GAB has been shown to bind and inhibit the small GTPase Rac1 by preventing its interaction with a guanine-nucleotide exchange factor, an interaction that involves the $\mathrm{C}$ terminus of GLS2 (residues 464 to 602) (40). Because the region contains the ANK repeats of $\mathrm{GAB}$, we predict that the contact involves the ANK concave face. Considering the long list of partners that were shown to interact with glutaminases using mass spectrometrybased approaches (51), further investigations are required to confirm the mechanism by which the ANK repeats in glutaminases mediate protein-protein interactions.

Last, although at low resolution, the novel ANK-containing structure of human KGA confirms our previous hypothesis that the long-range propagation of filaments for this isoform was thwarted by the presence of the ankyrin repeats themselves (23). As observed in the crystallographic model, the ANK dimer occludes the formation of the filamentation groove, by which the single strand filament of the GAC isoform grows indefinitely, via end to end interaction between pairs of $\mathrm{N}$-terminal domains. Because GAC possesses a shorter unstructured C-terminal sequence, this hypothesis is confirmed when the ANK domain is completely deleted in a mutant construct, which can form longer polymeric species, and therefore, resulting in a more active protein.

\section{Experimental procedures \\ Phylogenetic reconstruction}

726 Glutaminase protein sequences obtained from GenBank $^{\text {TM }}$ (52), by performing a BLAST search with human glutaminase domain sequence from GLS as the query, were aligned using kalign (53). Maximum likelihood phylogenetic reconstruction was performed with RaxML (54) with 260 bootstrap pseudoreplicates and using automated model search. Replicates were summarized with sumtrees from DendroPy (55). The generated phylogenetic tree and respective alignment were used to reconstruct ancestral states for specific nodes using maximum parsimony, as implemented in phangorn (56). Heatmaps from pairwise distances were constructed in SDT (57) using MUSCLE (58) alignment.

\section{Evolution of glutaminase exon structure}

Protein sequence corresponding to human GLS exon 14 was used as input of translated blast (tblastn) searches against avail- able genomes from C. intestinalis (27), B. floridae (28), P. marinus (29), C. milii (30), D. rerio (31), and X. tropicalis (32). After an initial Reciprocal Best Hit (59) region was found, the correct position of the exon was determined by pairwise LALIGN between sequences (60). Regions downstream from the genomic sequence homologous to exon 14 were also evaluated by LALIGN against human GAC-exclusive exon (exon 15). As both $P$. marinus glutaminases are incomplete, available exons were found in contig using the LALIGN approach. The GLS region comprising intron 14 , exon 15 , and intron 15 was used as input of TranspoGene (61) retrotransposon searching.

\section{Protein expression and purification}

The constructs of human KGA Val ${ }^{124}-\mathrm{Leu}^{669}$ and $\mathrm{Val}^{551}$ Leu $^{669}$ were amplified from the pcDNA3.1/hKGA-V5 clone, kindly provided by Dr. Richard Cerione (Cornell University, Ithaca, NY), and subcloned into the pET28a plasmid (Novagen) using the NdeI and XhoI restriction sites with $\mathrm{N}$-terminal $\mathrm{His}_{6}$ tag. KGA Val ${ }^{124}$ - Arg $^{550}$ was generated from the pET28a KGA $\mathrm{Val}^{124}$-Leu ${ }^{669}$ construct by site-directed mutagenesis of the $\mathrm{Val}^{551}$ residue into a stop codon (TAA) using the QuikChange II XL Site-directed Mutagenesis Kit (Agilent Technologies). The construct of human GAB Lys ${ }^{485}-\mathrm{Val}^{602}$ was cloned into pNIC28-Bsa4 plasmid. The construct of GAC Met ${ }^{128}-\mathrm{Ser}^{603}$ was amplified from a mouse fetal brain tissue cDNA library and cloned into the pET28a plasmid. The four constructs were transformed into Escherichia coli Rosetta-2 thermocompetent cells (Merck). Overnight cultures, grown in LB medium in the presence of $50 \mu \mathrm{g} \mathrm{ml}^{-1}$ of kanamycin and $50 \mu \mathrm{g} \mathrm{ml}^{-1}$ of cloramphenicol, were inoculated in a ratio of 1:100 in 3-liter cultures supplemented with the same antibiotics and left shaking at $200 \mathrm{rpm}$ for $5 \mathrm{~h}$ at $37^{\circ} \mathrm{C}$. The cultures were then downtempered to $18^{\circ} \mathrm{C}$ for $1 \mathrm{~h}$ before induction with $200 \mathrm{nM}$ isopropyl $\beta$-D-1-thiogalactopyranoside for $16 \mathrm{~h}$ at $18^{\circ} \mathrm{C}$. Cells were collected by rapid centrifugation and resuspended in $500 \mathrm{~mm}$ $\mathrm{NaCl}, 50 \mathrm{~mm}$ Tris $\mathrm{HCl}$, pH 8.5 (or 50 mm HEPES, pH 7.5, for GAB construct), $10 \%$ glycerol, and $2 \mathrm{~mm} \beta$-mercaptoethanol and $1 \mathrm{~mm}$ PMSF (phenylmethylsulfonyl fluoride). Cell lysis was performed chemically, by incubation with hen egg white lysozyme, DNase I, and deoxycholate (all three reagents from Sigma) for about $1 \mathrm{~h}$, incubated on ice. The soluble fractions were separated from the debris by high speed centrifugation and subsequently loaded, by gravity and in a cold room, on immobilized metal affinity column, $\mathrm{Co}^{2+}$-charged TALON (Clontech) for the GLS constructs and nickel-nitrilotriacetic acid Superflow (Qiagen) for the GAB construct, previously equilibrated with the running buffer $10 \mathrm{~mm} \mathrm{NaCl}$ and $50 \mathrm{~mm}$ Tris- $\mathrm{HCl}, \mathrm{pH} 8.5$, HEPES, $\mathrm{pH}$ 7.5. The constructs were eluted stepwise using running buffer to which up to $500 \mathrm{~mm}$ imidazole (v/v) had been added. For the GLS constructs, the tag was removed by overnight digestion with bovine thrombin (Sigma) and the samples loaded into a HiTrap Q HP anion exchange chromatography column (GE Healthcare). Elution was done by performing a linear gradient with a buffer containing $1 \mathrm{M} \mathrm{NaCl}$, $50 \mathrm{~mm}$ Tris- $\mathrm{HCl}, \mathrm{pH} 8.5$, and $2 \mathrm{~mm} \beta$-mercaptoethanol. The fractions containing the GLS constructs were loaded in a HiLoad 16/600 Superdex 200 (for KGA Val ${ }^{124}$-Leu ${ }^{669}$, KGA $\mathrm{Val}^{124}-\mathrm{Arg}^{550}$, and GAC Met ${ }^{128}-\mathrm{Ser}^{603}$ constructs) or 75 pg (GE 


\section{The multidomain architecture of human glutaminases}

Healthcare) (for $\mathrm{KGA} \mathrm{Val}^{551}-\mathrm{Leu}^{669}$ ). The final buffer conditions were $150 \mathrm{~mm} \mathrm{NaCl}, 30 \mathrm{~mm}$ HEPES, $\mathrm{pH} 8$, and $0.5 \mathrm{~mm}$ tris(2-carboxyethyl)phosphine). For the GAB construct, the eluate from the affinity chromatography was directly loaded in a HiLoad 16/600 75 pg. Protein concentration was determined by UV $280 \mathrm{~nm}$ using calculated extinction coefficients. The hydrodynamic parameters (Stokes radii, Rh) of human KGA, GAC, and the deletion mutant $\Delta \mathrm{C}$ were determined by gel filtration chromatography using a prepacked Superdex $200 \mathrm{HR}$ 10/30 column (GE Healthcare) in 25 mm Tris- $\mathrm{HCl}, \mathrm{pH}$ 8.0, 150 $\mathrm{mm} \mathrm{NaCl}, 0.5 \mathrm{~mm}$ tris(2-carboxyethyl)phosphine). For each purified protein, $\sim 1 \mathrm{mg} \mathrm{ml}^{-1}$ concentration in a $500-\mu \mathrm{l}$ volume was injected into the column. To induce the formation of the higher-order oligomeric species, $20 \mathrm{mM} \mathrm{K}_{2} \mathrm{HPO}_{4}$ as a final concentration was added in the protein solution before loading it onto the column. The gel filtration buffer was also supplemented with $20 \mathrm{~mm} \mathrm{~K}_{2} \mathrm{HPO}_{4}$. The flow rate was maintained at $0.5 \mathrm{ml} \mathrm{min}^{-1}$. To establish the hydrodynamic radius $(\mathrm{Rh})$ and elution volume relationship of the protein, proteins of known $\mathrm{Rh}$ were run on the same column. The proteins used as standards were ferritin $(440 \mathrm{kDa}, \mathrm{Rh}=60.8 \AA)$, aldolase $(158 \mathrm{kDa}$, $\mathrm{Rh}=48.1 \AA)$, conalbumin $(75 \mathrm{kDa}, \mathrm{Rh}=36.4 \AA)$, ovalbumin $(44 \mathrm{kDa}, \mathrm{Rh}=30.5 \AA)$, and ribonuclease A (13.7 kDa, $\mathrm{Rh}=15.9$ $\AA$ ).

\section{Crystallization}

Following size-exclusion purification, KGA Val ${ }^{124}$-Leu ${ }^{669}$ was concentrated using an Amicon 30-kDa cutoff concentrator (Millipore) to a final concentration of $\sim 7.5 \mathrm{mg} \mathrm{ml}^{-1}$. Crystallization experiments were performed at $277 \mathrm{~K}$ using the conventional sitting drop vapor diffusion technique. Drops were made by mixing two parts of protein previously incubated with 1.2 $\mathrm{mM}$ BPTES to one part of the well solution, containing $1.8 \mathrm{M}$ sodium formate, $0.5 \mathrm{M} \mathrm{NaCl}$, and $0.1 \mathrm{~m}$ BIS-TRIS propane, $\mathrm{pH}$ 6.8. Before data collection at cryogenic temperature (100 K), harvested crystals were cryoprotected with $10 \%$ ethylene glycol added to the mother liquor.

For large-scale limited proteolysis, KGA Val ${ }^{551}$-Leu ${ }^{669}$ after a size-exclusion purification step was incubated with 1:100 tryp$\sin$ (Sigma) at $23^{\circ} \mathrm{C}$ for $20 \mathrm{~min}$. The proteolysis was stopped by the addition of $1.5 \mathrm{~mm}$ PMSF. For limited proteolysis of GAB Lys $^{485}-\mathrm{Val}^{602}$, purified protein was incubated overnight with 1:1000 $\alpha$-chymotrypsin at $23^{\circ} \mathrm{C}$. The digested fragments were immediately purified by size-exclusion chromatography. For crystallization trials, digested KGA Val ${ }^{551}$-Leu ${ }^{669}$ and GAB Lys $^{485}-\mathrm{Val}^{602}$ were concentrated, respectively, to 25 and $50 \mathrm{mg}$ $\mathrm{ml}^{-1}$ using Amicon 10-kDa cutoff concentrators.

Both constructs were crystallized by sitting drop vapor diffusion, by mixing equal parts of protein solution and mother liquor. KGA Val ${ }^{551}$-Leu ${ }^{669}$ crystals were grown in (a) $3.2 \mathrm{M} \mathrm{NaCl}$, $0.1 \mathrm{M}$ Tris, $\mathrm{pH} 8.5$ and (b) $3.8 \mathrm{M} \mathrm{NH}_{4} \mathrm{Cl}, 0.1 \mathrm{M}$ BIS-TRIS propane, $\mathrm{pH}$ 7. GAB Lys ${ }^{485}-\mathrm{Val}^{602}$ crystals were grown in $1.1 \mathrm{M}$ trisodium citrate, $0.1 \mathrm{~m}$ imidazole, $\mathrm{pH} 8,20 \mathrm{~mm}$ L-glutamine.

\section{X-ray crystallography}

Diffraction data were collected at beamlines I03 at the Diamond Light Source (UK) and 12-2 at the Stanford Synchrotron Radiation Lightsource, respectively, for KGA Val ${ }^{124}-\mathrm{Leu}^{669}$ and for KGA/GAB ANK crystals. Datasets were integrated using Mosflm (62) (for native datasets) and XDS (63) (for sulfur-SAD dataset) and scaled with Aimless (64). The first set of phases of $\mathrm{KGA} \mathrm{Val}^{124}$-Leu ${ }^{669}$ was obtained by the molecular replacement technique as implemented in the program Phaser (65), using the coordinates of the mouse GAC isoform (PDB code 3SS3). KGA ANK was solved by sulfur-SAD using SHELX (66) and the model was refined using higher resolution native datasets. The model obtained for KGA was employed as a search model for solving the GAB ANK structure by molecular replacement (Table 1). Positional and $B$-factor refinement cycles, as well as solvent modeling, were performed with Refmac (67) and Phenix (68), followed by visual inspection using COOT (69).

\section{Glutaminase activity assay}

To obtain the kinetic parameters for KGA Val ${ }^{124}$-Leu ${ }^{669}$, KGA Val ${ }^{124}-\mathrm{Arg}^{550}$, and GAC $\mathrm{Met}^{128}$-Ser ${ }^{603}$, a mixture containing $10 \mathrm{~nm}$ glutaminase, $50 \mathrm{~mm}$ Tris acetate, $\mathrm{pH}$ 8.6, 3 units of bovine L-glutamate dehydrogenase (Sigma), 2 mM NAD (Sigma) was pipetted into 96-well plates previously filled with 6 or 12 serial dilutions of L-glutamine, to achieve a range of concentrations from 60 to $0.15 \mathrm{~mm}$. $\mathrm{K}_{2} \mathrm{HPO}_{4}$ (2 M stock, $\mathrm{pH} 9.4$ ) was added to the mixture at a final concentration of $20 \mathrm{mM}$. The formation of NADH was tracked by absorbance readings at 340 $\mathrm{nm}$, for up to five consecutive minutes, at room temperature. Measurements were done in triplicate. The initial velocities, in picomoles of $\mathrm{NADH}$ produced per second, were calculated using an extinction coefficient for NADH of $6,220 \mathrm{M}^{-1} \mathrm{~cm}^{-1}$ at $340 \mathrm{~nm}$ and $0.5 \mathrm{~cm}$ of path length. The total volume per reaction was $200 \mu$ l. Plate-reader used was an EnSpire (PerkinElmer Life Sciences). Measurements were done in triplicates and analyzed using GraphPad Prism 5.00 (GraphPad Software, San Diego, CA).

\section{Small-angle X-ray scattering}

Scattering data were collected at $\lambda=1.488 \AA$, for sampledetector distances of $1.1 \mathrm{~m}$ covering the momentum transfer ranges $0.015<\mathrm{s}<0.442 \AA^{-1}(\mathrm{~s}=4 \pi \sin \theta / \lambda$, where $2 \theta$ is the scattering angle). The data were normalized to the intensity of the incident beam and corrected for the detector response using an in-house program. Two frames of $250 \mathrm{~s}$ were collected and compared for radiation damage using the program PRIMUS (70). The same program was used to average the frames and subtract the buffer. The different protein concentrations were evaluated for aggregation by following increases in the measured $R_{g}$ (radius of gyration) as calculated by auto $R_{g}$. The $R_{g}$ was confirmed by using the indirect Fourier transform program GNOM (71), which was also used to calculate the distribution function $P(r)$ and $D_{\max }$. The data were analyzed and processed, including ab initio construction and model averaging, using the programs contained in the ATSAS package (72).

\section{Cryo-electron microscopy}

For visualization of cryogrids, purified GAB samples were frozen onto a Gatan 626 sample holder, prepared with FEI Vitrobot Mark II (force of -5 for $2 \mathrm{~s}$ ). Images were acquired using a JEM $2100(200 \mathrm{kV})$ electron microscope with a LaB6 filament Gatan $4 \mathrm{k} \times 4 \mathrm{k}$ slow scan CCD camera (US4000). Exposure time 


\section{The multidomain architecture of human glutaminases}

was $1 \mathrm{~s} /$ frame, with a dose of $20 e \AA^{-2} \mathrm{~s}^{-1}$. The micrographs were processed using IMAGIC (73) and EMAN 2.1 (74). Iterative stable alignment and clustering (ISAC) (75) was used to generate reference-free class-averages from both the IMAGIC stack (25,000 particles) and the EMAN2.1 stack (33,608 particles). Using IMAGIC and UCSF Chimera (76), 10,000 projection images in random orientations of the GAC crystallographic model (PDB code 3SS3) were generated, in both dimer and tetramer configurations. The bounding rectangle dimensions of 200 particles randomly extracted from the IMAGIC, EMAN2.1, ISAC/IMAGIC, and ISAC/EMAN2.1 datasets (50 from each) were classified according to longer (L) and shorter (S) dimensions. Images were low-pass filtered to reduce noise. Only the particles contained in the 50 "best" class averages generated by each program were considered (total: 200 particles). Measurements were performed in Digital Micrograph based on the integration profile across each perpendicular direction, as shown in Fig. 5C. Measurements were taken as the distance, in pixels, between the valleys confining the particle signal. For comparison, we also measured 200 randomly selected projections of the GAC atomic model in dimer and also in tetramer configuration.

Author contributions-S. M. G. D. and A. L. B. A. conceived and initiated the research; C. C. P., Z. I., D. A., I. M. F., R. D. R., J. B., R. V. P., and A. G. conducted the research; all authors analyzed and discussed the data; C. C. P., Z. I., D. A., S. M. G. D., and A. L. B. A. wrote the manuscript. All authors revised and approved the final manuscript.

Acknowledgments - We thank LNBio for accessibility to core facilities as well as for financial support. We are very grateful to Dr. Alessandra Girasole for expert technical support. We thank the Biotechnology group at the SGC Oxford for cloning and expression testing of glutaminase constructs. We thank Dr. Artur T. Cordeiro and Américo T. Ranzani for help with crystallographic data collection. We thank Dr. Wah Chiu for access to the cryo-electron microscopy facility at Baylor College of Medicine. We acknowledge the staff of all the beamlines used in this work. The KGA.ANK and GLS2.ANK data were collected during the RapiData 2015 Course for Data Collection and Structure Solving. Use of the Stanford Synchrotron Radiation Lightsource, SLAC National Accelerator Laboratory, is supported by the United States Department of Energy, Office of Science, Office of Basic Energy Sciences under Contract No. DE-AC02-76SF00515. The SSRL Structural Molecular Biology Program is supported by the DOE Office of Biological and Environmental Research, and National Institutes of Health, National Institute of General Medical Sciences Grant P41GM103393.

\section{References}

1. Bergström, J., Fürst, P., Norée, L. O., and Vinnars, E. (1974) Intracellular free amino acid concentration in human muscle tissue. J. Appl. Physiol. 36, 693-697

2. DeBerardinis, R. J., and Cheng, T. (2010) Q's next: the diverse functions of glutamine in metabolism, cell biology and cancer. Oncogene 29, 313-324

3. Levine, A. J., and Puzio-Kuter, A. M. (2010) The control of the metabolic switch in cancers by oncogenes and tumor suppressor genes. Science 330, $1340-1344$

4. Altman, B. J., Stine, Z. E., and Dang, C. V. (2016) From Krebs to clinic: glutamine metabolism to cancer therapy. Nat. Rev. Cancer 16, 619-634.

5. Wise, D. R., DeBerardinis, R. J., Mancuso, A., Sayed, N., Zhang, X.-Y., Pfeiffer, H. K., Nissim, I., Daikhin, E., Yudkoff, M., McMahon, S. B., and
Thompson, C. B. (2008) Myc regulates a transcriptional program that stimulates mitochondrial glutaminolysis and leads to glutamine addiction. Proc. Natl. Acad. Sci. U.S.A. 105, 18782-18787

6. Rathore, M. G., Saumet, A., Rossi, J.-F., de Bettignies, C., Tempé, D., Lecellier, C.-H., and Villalba, M. (2012) The NF- $\kappa$ B member p65 controls glutamine metabolism through miR-23a. Int. J. Biochem. Cell Biol. 44, $1448-1456$

7. Wang J. B., Erickson, J. W., Fuji, R., Ramachandran, S., Gao, P., Dinavahi, R., Wilson, K. F., Ambrosio, A. L., Dias, S. M., Dang, C. V., and Cerione, R. A. (2010) Targeting mitochondrial glutaminase activity inhibits oncogenic transformation. Cancer Cell. 18, 207-219

8. Colombo, S. L., Palacios-Callender, M., Frakich, N., De Leon, J., Schmitt, C. A., Boorn, L., Davis, N., and Moncada, S. (2010) Anaphase-promoting complex/cyclosome-Cdh1 coordinates glycolysis and glutaminolysis with transition to $S$ phase in human T lymphocytes. Proc. Natl. Acad. Sci. U.S.A. 107, 18868-18873

9. Lukey, M. J., Greene, K. S., Erickson, J. W., Wilson, K. F., and Cerione, R. A. (2016) The oncogenic transcription factor c-Jun regulates glutaminase expression and sensitizes cells to glutaminase-targeted therapy. Nat. Commun. 7, 11321

10. Suzuki, S., Tanaka, T., Poyurovsky, M. V., Nagano, H., Mayama, T., Ohkubo, S., Lokshin, M., Hosokawa, H., Nakayama, T., Suzuki, Y., Sugano, S., Sato, E., Nagao, T., Yokote, K., Tatsuno, I., and Prives, C. (2010) Phosphate-activated glutaminase (GLS2), a p53-inducible regulator of glutamine metabolism and reactive oxygen species. Proc. Natl. Acad. Sci. U.S.A. 107, 7461-7466

11. Hu, W., Zhang, C., Wu, R., Sun, Y., Levine, A., and Feng, Z. (2010) Glutaminase 2, a novel p53 target gene regulating energy metabolism and antioxidant function. Proc. Natl. Acad. Sci. U.S.A. 107, 7455-7460

12. Szeliga, M., and Albrecht, J. (2015) Opposing roles of glutaminase isoforms in determining glioblastoma cell phenotype. Neurochem. Int. 88, $6-9$

13. Szeliga, M., Bogacińska-Karaś M., Różycka, A., Hilgier, W., Marquez, J., and Albrecht, J. (2014) Silencing of GLS and overexpression of GLS2 genes cooperate in decreasing the proliferation and viability of glioblastoma cells. Tumour Biol. 35, 1855-1862

14. Liu, J., Zhang, C., Lin, M., Zhu, W., Liang, Y., Hong, X., Zhao, Y., Young, K. H., Hu, W., and Feng, Z. (2014) Glutaminase 2 negatively regulates the PI3K/AKT signaling and shows tumor suppression activity in human hepatocellular carcinoma. Oncotarget 5, 2635-2647

15. Krebs, H. (1935) Metabolism of amino-acids: The synthesis of glutamine from glutamic acid and ammonia, and the enzymic hydrolysis of glutamine in animal tissues. Biochem. J. 29, 1951-1969

16. Curthoys, N. P., Kuhlenschmidt, T., Weiss, R. F., and Godfrey, S. S. (1976) Phosphate-dependent activity glutaminase from rat kidney and identity with glutaminase in response to acidosis from other tissues. Arch. Biochem. Biophys. 172, 162-167

17. Curthoys, N. P., and Watford, M. (1995) Regulation of glutaminase activity and glutamine metabolism. Annu. Rev. Nutr. 15, 133-159

18. Elgadi, K. M., Meguid, R. A., Qian, M., Souba, W. W., and Abcouwer, S. F. (1999) Cloning and analysis of unique human glutaminase isoforms generated by tissue-specific alternative splicing. Physiol. Genomics 1, 51-62

19. Martín-Rufián, M., Tosina, M., Campos-Sandoval, J. A., Manzanares, E., Lobo, C., Segura, J. A., Alonso, F. J., Matés, J. M., and Márquez, J. (2012) Mammalian glutaminase Gls2 gene encodes two functional alternative transcripts by a surrogate promoter usage mechanism. PLoS ONE 7, e38380

20. Cassago, A., Ferreira, A. P., Ferreira, I. M., Fornezari, C., Gomes, E. R., Greene, K. S., Pereira, H. M., Garratt, R. C., Dias, S. M., and Ambrosio, A. L. (2012) Mitochondrial localization and structure-based phosphate activation mechanism of glutaminase $\mathrm{C}$ with implications for cancer metabolism. Proc. Natl. Acad. Sci. U.S.A. 109, 1092-1097

21. Campos-Sandoval, J. A., López de la Oliva, A. R., Lobo, C., Segura, J. A., Matés, J. M., Alonso, F. J., and Márquez, J. (2007) Expression of functional human glutaminase in baculovirus system: affinity purification, kinetic and molecular characterization. Int. J. Biochem. Cell Biol. 39, 765-773 


\section{The multidomain architecture of human glutaminases}

22. Olalla, L., Gutiérrez, A., Campos, J. A., Khan, Z. U., Alonso, F. J., Segura, J. A., Márquez, J., and Aledo, J. C. (2002) Nuclear localization of L-type glutaminase in mammalian brain. J. Biol. Chem. 277, 38939-38944.

23. Ferreira, A. P., Cassago, A., Gonçalves Kde, A., Dias, M. M., Adamoski, D., Ascenção, C. F., Honorato, R. V., de Oliveira, J. F., Ferreira, I. M. Fornezari, C., Bettini, J., Oliveira, P. S., Paes Leme, A. F., Portugal, R. V., Ambrosio, A. L., and Dias, S. M. (2013) Active glutaminase C self-assembles into a supratetrameric oligomer that can be disrupted by an allosteric inhibitor. J. Biol. Chem. 288, 28009-28020

24. Brown, G., Singer, A., Proudfoot, M., Skarina, T., Kim, Y., Chang, C., Dementieva, I., Kuznetsova, E., Gonzalez, C. F., Joachimiak, A., Savchenko, A., and Yakunin, A. F. (2008) Functional and structural characterization of four glutaminases from Escherichia coli and Bacillus subtilis. Biochemistry 47, 5724-5735

25. de Beer, T., Carter, R. E., Lobel-Rice, K. E., Sorkin, A., and Overduin, M. (1998) Structure and Asn-Pro-Phe binding pocket of the Eps15 homology domain. Science 281, 1357-1360

26. Pace, N. R. (2009) Mapping the tree of life: progress and prospects. Microbiol. Mol. Biol. Rev. 73, 565-576

27. Dehal, P., Satou, Y., Campbell, R. K., Chapman, J., Degnan, B., De Tomaso, A., Davidson, B., Di Gregorio, A., Gelpke, M., Goodstein, D. M., Harafuji, N., Hastings, K. E., Ho, I., Hotta, K., Huang, W., et al. (2002) The draft genome of Ciona intestinalis: insights into chordate and vertebrate origins. Science 298, 2157-2167

28. Putnam, N. H., Butts, T., Ferrier, D. E., Furlong, R. F., Hellsten, U., Kawashima, T., Robinson-Rechavi, M., Shoguchi, E., Terry, A., Yu, J.-K. Benito-Gutiérrez, E. L., Dubchak, I., Garcia-Fernàndez, J., Gibson-Brown, J. J., Grigoriev, I. V., et al. (2008) The amphioxus genome and the evolution of the chordate karyotype. Nature 453, 1064-1071

29. Smith, J. J., Kuraku, S., Holt, C., Sauka-Spengler, T., Jiang, N., Campbell, M. S., Yandell, M. D., Manousaki, T., Meyer, A., Bloom, O. E., Morgan, J. R., Buxbaum, J. D., Sachidanandam, R., Sims, C., Garruss, A. S., et al. (2013) Sequencing of the sea lamprey (Petromyzon marinus) genome provides insights into vertebrate evolution. Nat. Genet. 45, 415-421

30. Venkatesh, B., Lee, A. P., Ravi, V., Maurya, A. K., Lian, M. M., Swann, J. B. Ohta, Y., Flajnik, M. F., Sutoh, Y., Kasahara, M., Hoon, S., Gangu, V., Roy, S. W., Irimia, M., Korzh, V., et al. (2014) Elephant shark genome provides unique insights into gnathostome evolution. Nature 505, 174-179

31. Howe, K., Clark, M. D., Torroja, C. F., Torrance, J., Berthelot, C., Muffato, M., Collins, J. E., Humphray, S., McLaren, K., Matthews, L., McLaren, S. Sealy, I., Caccamo, M., Churcher, C., Scott, C., et al. (2013) The zebrafish reference genome sequence and its relationship to the human genome. Nature 496, 498-503

32. Hellsten, U., Harland, R. M., Gilchrist, M. J., Hendrix, D., Jurka, J., Kapitonov, V., Ovcharenko, I., Putnam, N. H., Shu, S., Taher, L., Blitz, I. L., Blumberg, B., Dichmann, D. S., Dubchak, I., Amaya, E., et al. (2010) The genome of the Western clawed frog Xenopus tropicalis. Science 328, 633-636

33. Sedgwick, S. G. and Smerdon, S. J. (1999) The ankyrin repeat: a diversity of interactions on a common structural framework. Trends Biochem. Sci. 24, 311-316

34. Mosavi, L. K., Cammett, T. J., Desrosiers, D. C., and Peng, Z.-Y. (2004) The ankyrin repeat as molecular architecture for protein recognition. Protein Sci. 13, 1435-1448

35. Krissinel, E., and Henrick, K. (2007) Inference of macromolecular assemblies from crystalline state. J. Mol. Biol. 372, 774-797

36. Robinson, M. M., McBryant, S. J., Tsukamoto, T., Rojas, C., Ferraris, D. V., Hamilton, S. K., Hansen, J. C., and Curthoys, N. P. (2007) Novel mechanism of inhibition of rat kidney-type glutaminase by bis-2-(5-phenylacetamido-1,2,4-thiadiazol-2-yl)ethyl sulfide (BPTES). Biochem. J. 406 $407-414$

37. Drozdetskiy, A., Cole, C., Procter, J., and Barton, G. J. (2015) JPred4: a protein secondary structure prediction server. Nucleic Acids Res. 43, W389-W394

38. Bergthorsson, U., Andersson, D. I., and Roth, J. R. (2007) Ohno's dilemma: evolution of new genes under continuous selection. Proc. Natl. Acad. Sci. 104, 17004-17009
39. Mosavi, L. K., Minor, D. L., Jr., and Peng, Z-Y. (2002) Consensus-derived structural determinants of the ankyrin repeat motif. Proc. Natl. Acad. Sci. 99, 16029-16034

40. Zhang, C., Liu, J., Zhao, Y., Yue, X., Zhu, Y., Wang, X., Wu, H., Blanco, F., Li, S., Haffty, B. G., Hu, W., and Feng, Z. (2016) Glutaminase 2 is a novel negative regulator of small GTPase Rac1 and mediates p53 function in suppressing metastasis. Elife 5, e10727

41. Scott, A. P. (1987) Reproductive endocrionology of fish. In Fundamentals of Comparative Vertebrate Endocrinology (Chester-Jones, I., Ingleton, P. M., Philips, and J. G., eds), pp. 223-256, Springer US, New York, NY

42. DeLaBarre, B., Gross, S., Fang, C., Gao, Y., Jha, A., Jiang, F., Song, J. J., Wei, W., and Hurov, J. B. (2011) Full-length human glutaminase in complex with an allosteric inhibitor. Biochemistry. 50, 10764-10770

43. Olalla, L., Gutiérrez, A., Jiménez, A. J., López-Téllez, J. F., Khan, Z. U., Pérez, J., Alonso, F. J., de la Rosa, V., Campos-Sandoval, J. A., Segura, J. A., Aledo, J. C., and Márquez, J. (2008) Expression of the scaffolding PDZ protein glutaminase-interacting protein in mammalian brain. J. Neurosci. Res. 86, 281-292

44. Russo, A. A., Tong, L., Lee, J.-O., Jeffrey, P. D., and Pavletich, N. P. (1998) Structural basis for inhibition of the cyclin-dependent kinase Cdk6 by the tumour suppressor p16INK4a. Nature 395, 237-243

45. Chiswell, B. P., Zhang, R., Murphy, J. W., Boggon, T. J., and Calderwood, D. A. (2008) The structural basis of integrin-linked kinase-PINCH interactions. Proc. Natl. Acad. Sci. U.S.A. 105, 20677-20682

46. Takeda, S., Minakata, S., Koike, R., Kawahata, I., Narita, A., Kitazawa, M., Ota, M., Yamakuni, T., Maéda, Y., and Nitanai, Y. (2010) Two distinct mechanisms for actin capping protein regulation: steric and allosteric inhibition. PLos Biol. 8, e1000416

47. Holzer, S., Ban, N., and Klinge, S. (2013) Crystal structure of the yeast ribosomal protein rpS3 in complex with its chaperone Yar1. J. Mol. Biol. 425, $4154-4160$

48. Robin, G., Sato, Y., Desplancq, D., Rochel, N., Weiss, E., and Martineau, P. (2014) Restricted diversity of antigen binding residues of antibodies revealed by computational alanine scanning of 227 antibody-antigen complexes. J. Mol. Biol. 426, 3729-3743

49. Li, Y., Meng, X., Xiang, Y., and Deng, J. (2010) Structure function studies of vaccinia virus host range protein $\mathrm{k} 1$ reveal a novel functional surface for ankyrin repeat proteins. J. Virol. 84, 3331-3338

50. Hesketh, G. G., Pérez-Dorado, I., Jackson, L. P., Wartosch, L., Schäfer, I. B., Gray, S. R., McCoy, A. J., Zeldin, O. B., Garman, E. F., Harbour, M. E., Evans, P. R., Seaman, M. N., Luzio, J. P., and Owen, D. J. (2014) VARP is recruited on to endosomes by direct interaction with retromer, where together they function in export to the cell surface. Dev. Cell. 29, 591-606

51. Huttlin, E. L., Ting, L., Bruckner, R. J., Gebreab, F., Gygi, M. P., Szpyt, J., Tam, S., Zarraga, G., Colby, G., Baltier, K., Dong, R., Guarani, V., Vaites, L. P., Ordureau, A., Rad, R., et al. (2015) The BioPlex network: a systematic exploration of the human interactome. Cell 162, 425-440

52. Clark, K., Karsch-Mizrachi, I., Lipman, D. J., Ostell, J., and Sayers, E. W. (2016) GenBank. Nucleic Acids Res. 44, D67-D72

53. Lassmann, T., and Sonnhammer, E. L. (2005) Kalign: an accurate and fast multiple sequence alignment algorithm. BMC Bioinformatics 6, 298

54. Stamatakis, A. (2014) RAxML version 8: a tool for phylogenetic analysis and post-analysis of large phylogenies. Bioinformatics 30, 1312-1313

55. Sukumaran, J., and Holder, M. T. (2010) DendroPy: a Python library for phylogenetic computing. Bioinformatics 26, 1569-1571

56. Schliep, K. P. (2011) phangorn: phylogenetic analysis in R. Bioinformatics 27, 592-593

57. Muhire, B. M., Varsani, A., and Martin, D. P. (2014) SDT: a virus classification tool based on pairwise sequence alignment and identity calculation. PLOS ONE 9, e108277

58. Edgar, R. C. (2004) MUSCLE: multiple sequence alignment with high accuracy and high throughput. Nucleic Acids Res. 32, 1792-1797

59. Tatusov, R. L., Koonin, E. V., and Lipman, D. J. (1997) A genomic perspective on protein families. Science 278, 631-637

60. Huang, X., and Miller, W. (1991) A time-efficient, linear-space local similarity algorithm. Adv. Appl. Math. 12, 337-357 
The multidomain architecture of human glutaminases

61. Levy, A., Sela, N., and Ast, G. (2008) TranspoGene and microTranspoGene: transposed elements influence on the transcriptome of seven vertebrates and invertebrates. Nucleic Acids Res. 36, D47-D52

62. Leslie, A. G. W., and Powell H. R. (2007) Processing diffraction data with mosflm. In Evolving methods for macromolecular crystallography (Read, R. J., and Sussman, J. L., eds), pp. 41-51, Springer, Dordrecht, Netherlands

63. Kabsch, W. (2010) XDS. Acta Crystallogr. D Biol. Crystallogr. 66, 125-132

64. Evans, P. R., and Murshudov, G. N. (2013) How good are my data and what is the resolution? Acta Crystallogr. D Biol. Crystallogr. 69, 1204-1214

65. McCoy, A. J., Grosse-Kunstleve, R. W., Adams, P. D., Winn, M. D., Storoni, L. C., and Read, R. J. (2007) Phaser crystallographic software. J. Appl. Crystallogr. 40, 658-674

66. Sheldrick, G. M. (2010) Experimental phasing with SHELXC/D/E: combining chain tracing with density modification. Acta Crystallogr. D Biol. Crystallogr. 66, 479-485

67. Vagin, A. A., Steiner, R. A., Lebedev, A. A., Potterton, L., McNicholas, S. Long, F., and Murshudov, G. N. (2004) REFMAC5 dictionary: organization of prior chemical knowledge and guidelines for its use. Acta Crystallogr. D Biol. Crystallogr. 60, 2184-2195

68. Adams, P. D., Afonine, P. V., Bunkóczi, G., Chen, V. B., Davis, I. W., Echols, N., Headd, J. J., Hung, L.-W., Kapral, G. J., Grosse-Kunstleve, R. W., McCoy, A. J., Moriarty, N. W., Oeffner, R., Read, R. J., Richardson, D. C., Richardson, J. S., Terwilliger, T. C., and Zwart, P. H. (2010) PHENIX: a comprehensive Python-based system for macromolecular structure solution. Acta Crystallogr. D Biol. Crystallogr. 66, 213-221
69. Emsley, P., Lohkamp, B., Scott, W. G., and Cowtan, K. (2010) Features and development of Coot. Acta Crystallogr. D. Biol. Crystallogr. 66, 486-501

70. Konarev, P. V., Volkov, V. V., Sokolova, A. V., Koch, M. H. J., and Svergun, D. I. (2003) PRIMUS: a Windows PC-based system for small-angle scattering data analysis. J. Appl. Crystallogr. 36, 1277-1282

71. Svergun, D. I. (1992) Determination of the regularization parameter in indirect-transform methods using perceptual criteria. J. Appl. Crystallogr. 25, 495-503

72. Petoukhov, M. V., Konarev, P. V., Kikhney, A. G., and Svergun, D. I. (2007) ATSAS 2.1: towards automated and web-supported small-angle scattering data analysis. J. Appl. Crystallogr. 40, s223-s228

73. van Heel, M., Portugal, R., Rohou, A., Linnemayr, C., Bebeacua, C., Schmidt, R., Grant, T., and Schatz, M. (2012) Four-dimensional cryoelectron microscopy at quasi-atomic resolution: IMAGIC 4D. Int. Tables. Acta Crystallogr. Vol. F, ch. 19.9, 624-628

74. Tang, G., Peng, L., Baldwin, P. R., Mann, D. S., Jiang, W., Rees, I., and Ludtke, S. J. (2007) EMAN2: An extensible image processing suite for electron microscopy. J. Struct. Biol. 157, $38-46$

75. Yang, Z., Fang, J., Chittuluru, J., Asturias, F. J., and Penczek, P. A. (2012) Iterative stable alignment and clustering of $2 \mathrm{D}$ transmission electron microscope images. Structure 20, 237-247

76. Pettersen, E. F., Goddard, T. D., Huang, C. C., Couch, G. S., Greenblatt, D. M., Meng, E. C., and Ferrin, T. E. (2004) UCSF Chimera: a visualization system for exploratory research and analysis. J. Comput. Chem. 25, 1605-1612 
Received: 26 March 2015

Accepted: 07 July 2015

Published: 03 August 2015

\section{Hypoxia-inducible factor $3 \alpha$}

Angela M. Fala ${ }^{1,{ }^{*}}$, Juliana F. Oliveira ${ }^{1,{ }^{*}}$, Douglas Adamoski ${ }^{1}$, Juliana A. Aricetti ${ }^{2}$, Marilia M. Dias ${ }^{1}$, Marcio V. B. Dias ${ }^{1, *}$, Maurício L. Sforça ${ }^{1}$, Paulo S. Lopes-de-Oliveira ${ }^{1}$, Silvana A. Rocco ${ }^{1}$, Camila Caldana ${ }^{2,3}$, Sandra M. G. Dias $^{1,+}$ \& Andre L. B. Ambrosio ${ }^{1,+}$

Hypoxia-inducible transcription factors (HIF) form heterodimeric complexes that mediate cell responses to hypoxia. The oxygen-dependent stability and activity of the HIF- $\alpha$ subunits is traditionally associated to post-translational modifications such as hydroxylation, acetylation, ubiquitination, and phosphorylation. Here we report novel evidence showing that unsaturated fatty acids are naturally occurring, non-covalent structural ligands of HIF- $3 \alpha$, thus providing the initial framework for exploring its exceptional role as a lipid sensor under hypoxia.

HIF, closely linked to disorders of the circulatory system and cancer progression ${ }^{1}$, consists of two multidomain subunits including the constitutively expressed HIF-1 $\beta$ and an oxygen-labile HIF- $1 \alpha$ (or paralogs HIF- $2 \alpha$ and $-3 \alpha$ ). The gene encoding for HIF- $3 \alpha$ (HIF3A) is exclusively susceptible to post-transcriptional processing in humans, with six isoforms shown to exist at mRNA levels and three already confirmed as functional protein ${ }^{2,3}$. HIF-3 $\alpha 9$, the longest (669 aa) and canonical isoform ${ }^{3}$, is a potent oxygen-labile transcription factor, tightly regulating the expression of a unique set of genes ${ }^{4}$. HIF- $3 \alpha 4$ ( $\left.363 \mathrm{aa}\right)$, on the other hand, while insensitive to intracellular oxygen levels and incapable of transactivation, is a dominant-negative regulator of HIF- $1 \alpha^{5}$. Due to the use of different transcription initiation sites and a combination of splicing events in HIF3A, the C-terminal Per-Arnt-Sim sensor domain (PASb) is the only common architectural feature among the HIF- $3 \alpha$ isoforms ${ }^{3}$. The PASb domains in both HIF- $\alpha$ and $-\beta$ subunits have a crucial role in forming active HIF heterodimers and recruiting co-regulators ${ }^{6,7}$.

PAS members are versatile sensory modules of stimuli such as oxygen tension, redox state and light intensity through binding to cofactors such as heme, flavin adenine dinucleotide and even divalent metal ions ${ }^{8}$. In the case of the HIF proteins, PAS domains-mediated protein-protein interactions have been shown independently of a cofactor and simply based on the presence of the partner PAS 9,10 . However, recently, the identification of a $290 \AA^{3}$ polar cavity in HIF- $2 \alpha$ PASb domain led to the proposition that endogenous ligands may exist ${ }^{11}$; this cavity was later exploited for the selection of artificial small molecules that disrupt the full-length HIF-2 heterodimer ${ }^{10-12}$.

Hereby, we present the crystal structure of the recombinant human HIF-3 $\alpha$ PASb, or PASb-3 $\alpha$, at $1.15 \AA$ maximum resolution (Table 1 and Supplementary Fig. 1). Although with a backbone virtually identical to that of the PASb domains of both HIF- $1 \alpha^{9}$ and HIF- $2 \alpha^{10}$ (Fig. 1a), PASb- $3 \alpha$ has a unique extensive C-shaped hydrophobic cavity of $510 \AA^{3}$ (Fig. 1b). We identified a 1-(11Z-octadecenoyl)-sn-

${ }^{1}$ Laboratório Nacional de Biociências and '2Laboratório Nacional de Ciência e Tecnologia do Bioetanol, Centro Nacional de Pesquisa em Energia e Materiais, Campinas, SP, Brazil, 13083-100. 3Max Plack-partner group at the Laboratório Nacional de Ciência e Tecnologia do Bioetanol. " Current address: Institute of Biomedical Science, University of São Paulo, São Paulo, SP, 05508-000, Brazil. *These authors contributed equally to this work. 'These authors jointly supervised this work. Correspondence and requests for materials should be addressed to S.M.G.D. (email: sandra.dias@Inbio.cnpem.br) or A.L.B.A. (email: andre.ambrosio@Inbio.cnpem.br) 


\begin{tabular}{|c|c|c|c|}
\hline \multicolumn{4}{|c|}{ The C-terminal Per-Arnt-Sim (PASb) domain of human HIF-3 $\alpha 9$ bound to 18:1-1-monoacylglycerol, PDB ID 4wn } \\
\hline \multicolumn{2}{|c|}{ Data Collection } & \multicolumn{2}{|c|}{ Model Refinement } \\
\hline Beamline & P13 at PETRA III & Resolution range $(\AA)$ & $28.5-1.15$ \\
\hline Wavelength $(\AA)$ & 0.9770 & Reflections (cross-validation) & $68777(5952)$ \\
\hline Space group & $\mathrm{P} 2_{1} 22_{1}$ & $\mathrm{R}_{\text {factor }} / \mathrm{R}_{\text {free }}(\%)$ & $12.2 / 14.1$ \\
\hline Cell parameters a, b, c $(\AA)$ & $52.7,53.9,67.8$ & \multicolumn{2}{|l|}{ Average B-factor $\left(\AA^{2}\right)$} \\
\hline Resolution range $(\AA)$ & $28.5-1.15(1.17-1.15)$ & main chain (no. of atoms) & $8.8(870)$ \\
\hline Unique reflections & $68827(3381)$ & side chain (no. of atoms) & $13.2(812)$ \\
\hline Multiplicity & $9.8(9.1)$ & ligands (no. of atoms) & $19.9(155)$ \\
\hline $\mathrm{R}_{\mathrm{pim}}(\%)$ & $1.9(5.2)$ & solvent (no. of atoms) & $28.0(295)$ \\
\hline CC $(1 / 2)$ & $0.998(0.987)$ & & \\
\hline Completeness (\%) & $99.3(99.4)$ & \multicolumn{2}{|l|}{ R.m.s.d. from standard geometry } \\
\hline$<\mathrm{I} / \sigma(\mathrm{I})>$ & $22.8(11.5)$ & bond length $(\AA)$ & 0.01 \\
\hline Average mosaicity $\left(^{\circ}\right)$ & 0.5 & bond angles $\left({ }^{\circ}\right)$ & 1.36 \\
\hline B-factor Wilson Plot $\left(\AA^{2}\right)$ & 6.7 & & \\
\hline Monomers/AU & 2 & Ramachandran plot, & \\
\hline Solvent content (\%) & 36.1 & favored $(\%)$ & 100 \\
\hline Matthews coeff. $\left(\mathrm{A}^{3} / \mathrm{Da}\right)$ & 1.92 & & \\
\hline
\end{tabular}

Table 1. X-ray crystallography data collection parameters and structure refinement statistics. Data for outer shell are shown in parentheses.

glycerol molecule of bacterial nature buried in this cavity, as clearly suggested by the size and geometrical features of the electron density map (Fig. 1c, left panel). As such, the aliphatic tail of the fatty acid extended to eighteen carbons in length (maximum length limited by the cavity size), with a cis double bond between $\mathrm{C} 11$ and $\mathrm{C} 12$, interspersed by four gauche configurations (at positions C5, C7, C9 and C13, (Fig. 1c, right panel)). The ester group at the glycerol sn-1 position makes polar contact with the main chain carboxyl group of His339 and main chain amino group of Leu340. The sn-2 position is not substituted, also sharing a hydrogen bond with the Leu340 main chain amino group (Fig. 1d). Based solely on the electron density map, we could not tell whether the glycerol sn-3 position was substituted, due to absence of well-structured atoms beyond its remaining hydroxyl group. However, the presence of a well-coordinate sulfate ion (abundant in the crystallization solution), $6 \AA$ apart from the glycerol sn-3 hydroxyl, suggested that PASb- $3 \alpha$ could also bind to phospholipids (Fig. 1d).

Aiming at experimental confirmation of the identity of the proposed monoacylglycerol, the hydrophobic fraction was carefully isolated from pure protein samples in solution and analyzed by thin-layer chromatography (TLC). By applying two mobile phases distinct in polarity, as well as dual staining to allow for differential detection of neutral and phosphorous-containing lipids ${ }^{13}$, we surprisingly observed the dominant presence of two neutral lipids and two phospholipids as ligands of PASb-3 $\alpha$ (Fig. 2a).

Accordingly, mass spectrometry analysis on the isolated hydrophobic fraction readily identified two differential peaks with $\mathrm{m} / \mathrm{z}$ of 478.40 and 509.36 (Supplementary Fig. 2a,b), subsequently determined to be the lyso-phospholipids 1-(11Z-octadecenoyl)-2-hydroxy-sn-glycero-3-phosphoethanolamine, or 18:1-LPE, and 1-(11Z-octadecenoyl)-2-hydroxy-sn-glycero-3-phospho-(1'-sn-glycerol), or 18:1-LPG, respectively (Fig. 2a), in accordance with the TLC analysis. Experimental limitations related to the ionization of the neutral lipids kept us from identifying the precise nature of such.

Collectively, all complex lipids identified as PASb-3 $\alpha$ ligands include the 18-carbon unsaturated 11Z-octadecenoic acid (or cis-vaccenic acid; 18:1, cis-11) and an unmodified sn-2 glycerol position as common structural denominators. Given the heterologous nature of the expression system used for human PASb- $3 \alpha$ production, it is key to mention that cis-vaccenic is the sole 18-carbon unsaturated fatty acid found in E. coli $i^{14}$.

Next, in order to quantitatively check whether the degree of unsaturation influenced the binding of 18-carbon fatty acids to PASb- $3 \alpha$, we performed a fluorescence-based assay in the presence of the hydrophobic probe 1,8-ANS, upon the titration of fatty acids to the delipidated protein. Intriguingly, upon fatty acid titration, no clear dose-response curve was observed for stearic acid (18:0), while sigmoid curves could be fitted in response to both oleic (18:1; cis-9) and linoleic acids (18:2; cis-9,12) (Fig. 2b). An apparent $K_{d}$ of $39 \mathrm{~nm}$ for the monounsaturated oleic acid was determined, which improved 50 -fold (up to $0.8 \mathrm{nM}$ ) for the polyunsaturated linoleic acid. Therefore, in addition to showing that 18-carbon fatty acids that occur in human cells, such as oleic and linoleic acids, are high-affinity ligands of PASb-3 $\alpha$, we also establish that unsaturation is a required feature for fatty acid binding and the greater the degree of unsaturation, the stronger the interaction with the protein becomes. 


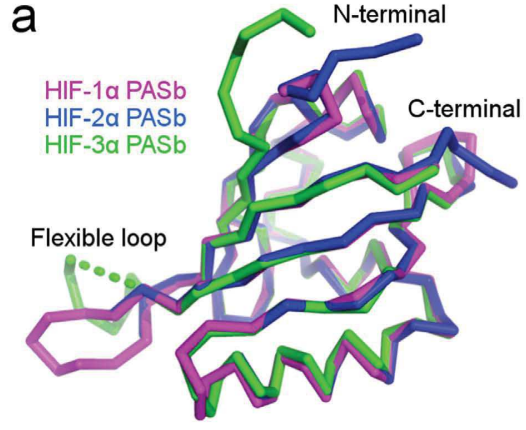

Fourier difference omit map

C contoured at $3 \sigma\left(0.7 \mathrm{e} / \AA^{3}\right)$

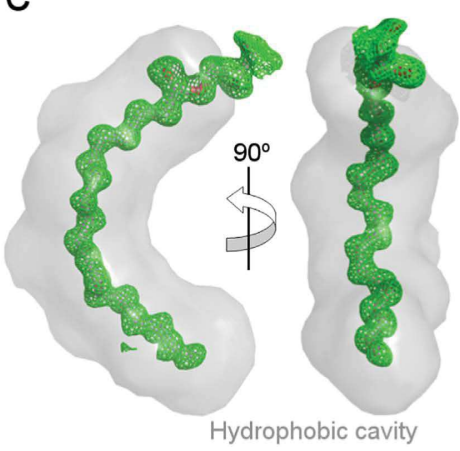

Electron density map, 2D projection

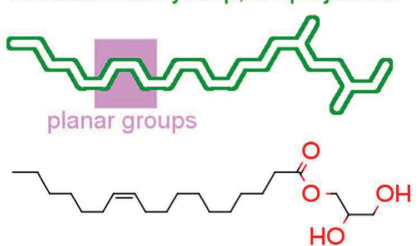

1-(11Z-octadecenoyl)-sn-glycerol
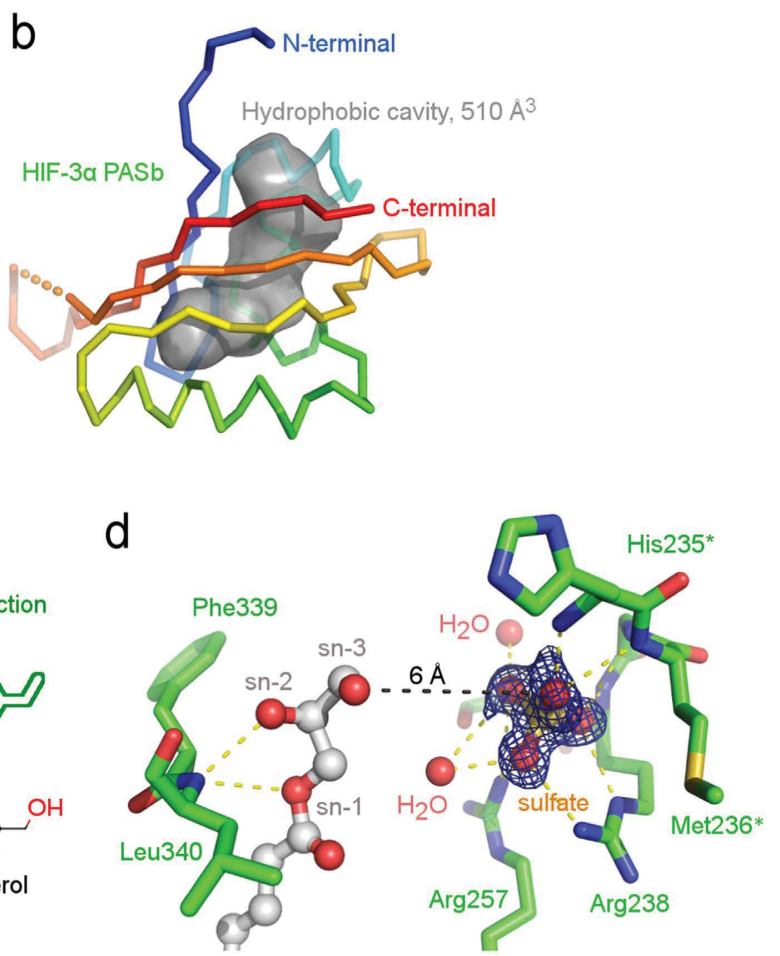

Figure 1. Structure of lipid-bound PASb-3 $\alpha$. (a) High structural identity between the main chain tracing of PASb- $3 \alpha$ and the PASb domains of both HIF- $1 \alpha$ and HIF- $2 \alpha$ (similar core r.m.s.d. of $0.6 \AA$ ).

(b) However, a $510 \AA^{3}$ hydrophobic cavity was exclusively identified in the core of PASb-3 $\alpha$ (delimited by gray surface), and (c) found to enclose a monoacylglycerol molecule. (d) Extensive network of polar contacts (yellow dashed lines) shared by specific residues in PASb-3 $\alpha$ with the lipid and a neighbor sulfate ion, suggesting that minor rearrangements in the protein may allow for binding of phospholipids.

The mechanism by which the lipid molecule enters the PASb- $3 \alpha$ pocket is unclear. However, the outcomes of the binding assay above can be reasoned from the perspective of the free fatty acids, since the ligand conformations in the bound state are dependent on the frequency of such microstates as part of the unbound ensemble in vacuum (thus simulating lipid desolvation). Upon ensemble recapitulation, it is curious to observe that, while the putative bound conformation of stearic acid has the lowest conformational enthalpy inside the pocket $(-3 \mathrm{kcal} / \mathrm{mol})$, such a conformation has very low probability of happening upon desolvation (Fig. 2c). On the other hand, the bound conformations of oleic and linoleic acids, although with higher enthalpies ( 4 and $37 \mathrm{kcal} / \mathrm{mol}$, respectively), are more frequent and easily achieved since the estimated ensemble entropies are significantly smaller than that of stearic acid (Fig. 2c).

NMR and fluorescence polarization data showed that purified, lipid-associated PASb-3 $\alpha$, has stronger association with HIF-1 $\beta$ PASb, albeit with slower binding kinetics, when compared to the well-characterized HIF-1 $\alpha$ :HIF-1 $\beta$ PASb dimer (Supplementary Fig. 3a-e). In hopes of characterizing exactly how the absence of lipids could affect the heterodimerization of PASb-3 $\alpha$ to HIF-1 $\beta$ PASb, we performed extensive attempts to remove the accompanying bacterial lipids from the purified protein by conventional hydrophobic interaction chromatography, reversible unfolding and detergents, all of which failed. Limited success was attained after treatment with the LIPIDEX-1000 matrix allowing, however, the recovery of only minor amounts of protein ${ }^{15}$. This observation may point to the role of the lipids as a structural cofactors for PASb-3 $\alpha$, which is not without precedents, since some ligand-free PAS have already been shown to be predominantly unstructured in solution and prone to precipitation ${ }^{16,17}$. A fitting example is the association between the ligand-free PASb domain of the Aryl Hydrocarbon Receptor (AHR), with a predicted similarly large hydrophobic cavity $\left(500 \AA^{3}\right)$ used for ligand binding, and the chaperone Heat shock protein 90 (Hsp90). The presence of compounds known to activate the AHR response pathway displaces Hsp90 from this complex, suggesting that these chemicals stabilize a folded form of the PASb domain ${ }^{18}$. Therefore, we suggest that the binding of lipids to PASb is mandatory for the proper folding and stability of HIF- $3 \alpha$, inducing its translocation to the nucleus and subsequent activation of HIF function. This hypothesis is strongly supported by the direct observation that HIF- $3 \alpha$ 


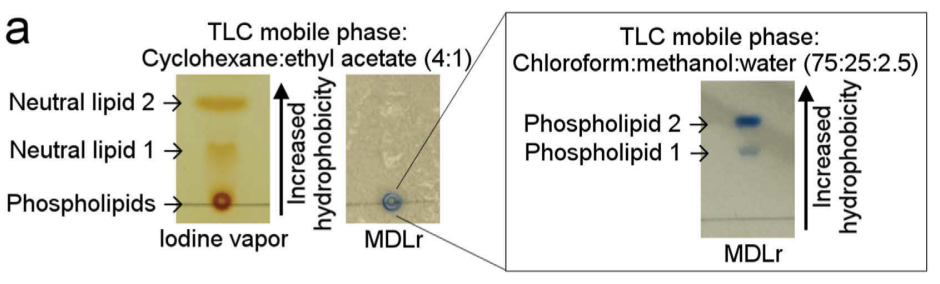

Phospholipid $2 \rightarrow 18: 1-$ LPG, $\mathrm{m} / \mathrm{z}=509.36$
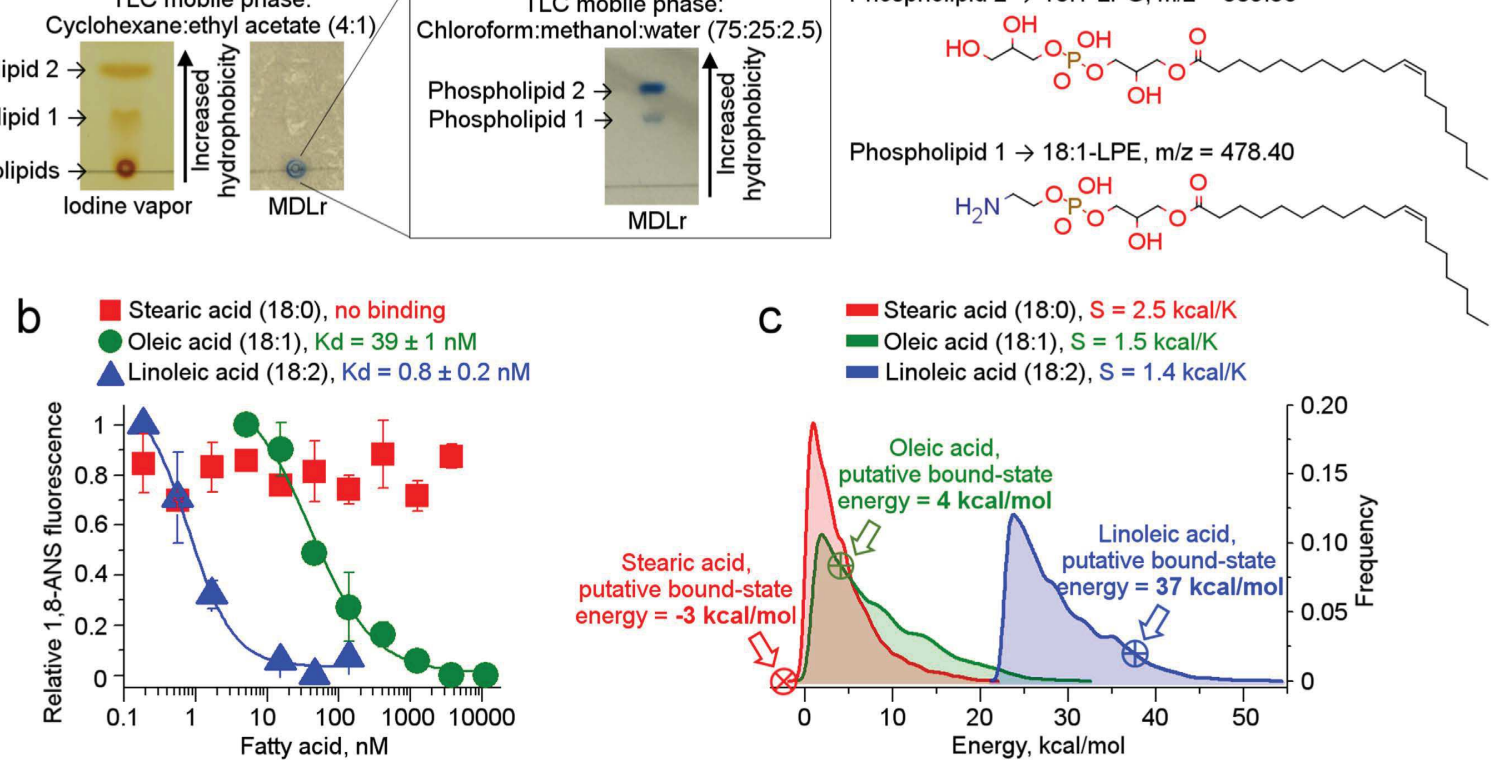

Figure 2. Characterization of the lipids bound to PASb-3 $\alpha$. (a) Two neutral lipids (yellow bands on the iodine vapor stained plate) and two phosphorous-containing lipids (blue bands over white background) were carried over by the purified protein samples. The two phospholipids were identified as 18:1-lysophospholipds. (b) Free oleic and linoleic acids bind with low-nanomolar affinity to delipidated PASb-3 $\alpha$, suggesting that unsaturation is a mandatory feature for the partner fatty acid and, as unsaturation accumulates, the higher the affinity for the protein. (c) Boltzmann distributions representing the canonical ensembles of fatty acid desolvation. The estimated entropies decrease as the degree of unsaturation increase. Crossed-circles over the curves point out the frequency of putative bound-state enthalpy into the distribution.

indeed co-precipitates with HSP90 in cell models, likely via its PASb domain ${ }^{19}$. However, the dependence of this interaction on the presence of lipids has yet to be tested.

Curiously, the splicing event that gives rise to the HIF-3 34 isoform completely changes the amino acid sequence for the second half of its PASb domain ${ }^{3}$ (Supplementary Fig. 4a). Ab initio homology modelling of PASb-3 $\alpha 4$ strongly suggest that amino acid changes relative to PASb-3 $\alpha$ (Supplementary Fig. 4a), result in substantial deformation of the topography of the hydrophobic cavity as a consequence of the presence of longer, bulkier and polar side chains inside the cavity (Supplementary Fig. 4b). These observations strongly suggest that, out of all HIF-3 $\alpha$ isoforms, the splicing variant HIF-3 $\alpha 4$ - which is uniquely insensitive to cellular oxygen levels ${ }^{5}$ - may as well be exclusively insensitive to lipids. Of note, HIF-3 $\alpha 4$ is a negative regulator of HIF- $1^{5}$. Extensive attempts to produce PASb-3 $\alpha 4$ domain in bacterial system only resulted in insoluble protein products, hindering the testing of our hypothesis.

With all the possible scenarios described above several outstanding questions arise. These include the identification of which lipids may in fact regulate HIF-3 $\alpha$ function, for instance in cancer (Supplementary Figs. $5 \mathrm{a}-\mathrm{b}$ and $6 \mathrm{a}-\mathrm{d}$ ) or obesity ${ }^{20}$, under what exact circumstances lipids must be sensed and what are the possible outcomes of lipid binding. However, by defining PASb-3 $\alpha$ as a lipid-binding domain, our findings lay the groundwork to explore the role of HIF- $3 \alpha$ as a link coupling lipid sensing under hypoxia, thus adding an unanticipated layer of complexity to the already intricate mechanism for HIF-mediated gene expression. Finally, similarly to HIF-2 $\alpha$, the description of an exclusive hydrophobic pocket yield unique implications for the future development of small molecule-oriented therapeutics targeting specifically HIF-3 $\alpha$.

Collectively, our structural and biochemical observations also carry implications for the overall molecular aspects of the PAS fold. For the first time, we document that a eukaryotic PAS domain may have lipids as high-affinity cofactors, thus introducing a new class of PAS ligands and expanding its already vast functional portfolio ${ }^{8}$.

\section{Methods}

Cloning. PASb-1 $\alpha$ (Asp238-His348, UniProt Q16665), PASb-1 $\beta$ (Pro349-Ser467, UniProt P27540) and PASb-3 $\alpha$ (Gly237-Thr345, UniProt Q9Y2N7-1) coding sequences were amplified by Polimerase Chain Reaction from a cDNA library from the breast cancer cell line SKBR3. PASb-1 $\alpha$ and PASb-3 $\alpha$ constructs were cloned into the pET28a plasmid (Novagen) using the NdeI and XhoI restriction sites. PASb- $1 \beta$ was cloned into a modified version of pETSUMO vector (Invitrogen) using BamHI and HindIII 
restriction sites. The following pairs of oligonucleotides were used: PASb- $1 \alpha$ - Forward: $5^{\prime}$-AGTCTCA TATGGATAGCAAGACTTTCCTCAGTCGA- ${ }^{\prime}$ and Reverse: $5^{\prime}$-CGTACCTCGAGTTAGTGCTGAATA ATACCACTCAC-3'; PASb-1 $\beta$ - Forward: 5' -TTGGTGGATCCCCCAACTGTACAGACATGAGTAAT$3^{\prime}$ and Reverse: 5' -GCCGCAAGCTTTTAAGAGTTCTTCACATTGGTGTT-3'; PASb-3 $\alpha$ - Forward: $5^{\prime}$ AGTCTCATATGGGCCGAGGGGCCTTCCTCAGCCGC- $3^{\prime}$ and Reverse: $5^{\prime}$-CGTACCTCGAGTTAGG TCTCTTCCACCTGGCTGAT-3'.

Expression and purification of recombinant proteins. The following expression and purification protocol was applied to the three Pasb constructs, transformed into Escherichia coli Rosetta-2 thermocompent cells (Merck). Overnight cultures, grown in LB medium supplemented by $50 \mu \mathrm{g} \cdot \mathrm{ml}^{-1}$ kanamycin and $50 \mu \mathrm{g} . \mathrm{ml}^{-1}$ cloramphenicol, were inoculated in a ratio of 1:100 in 5 liter cultures supplemented with the same antibiotics and left shaking at $200 \mathrm{rpm}$ for 5 hours at $37^{\circ} \mathrm{C}$. The cultures were then down-tempered to $18^{\circ} \mathrm{C}$ for 1 hour before induction with $0.2 \mathrm{mM}$ IPTG (isopropyl $\beta$-D-1-thiogalactopyranoside) for additional 16 hours at $18^{\circ} \mathrm{C}$. Cells were harvested by centrifugation $(5,000 \times \mathrm{g})$ for $10 \mathrm{~min}$ at $4{ }^{\circ} \mathrm{C}$ and resuspended in buffer containing $50 \mathrm{mM}$ Tris- $\mathrm{HCl} \mathrm{pH} 7.5,150 \mathrm{mM} \mathrm{NaCl}, 10 \%$ glycerol, $2 \mathrm{mM}$ BME ( $\beta$-mercaptoethanol) and $1 \mathrm{mM}$ phenylmethylsulfonyl fluoride. Cell lysis was performed chemically by incubation with hen egg-white lysozyme, DNAse I and deoxycholate (all three reagents from Sigma-Aldrich) for about 1 hour, incubated on ice. The soluble fractions were separated from the debris by high speed centrifugation $(23,000 \times \mathrm{g})$ and subsequently loaded, by gravity, on $\mathrm{Co}^{2+}$-charged resin TALON (Clontech), previously equilibrated with the running buffer $50 \mathrm{mM}$ Tris- $\mathrm{HCl} \mathrm{pH} 7.5,30 \mathrm{mM}$ $\mathrm{NaCl}$ and $2 \mathrm{mM}$ BME. The constructs, bearing a $6 \mathrm{xHis}$-tag fused to their N-terminus, were eluted stepwise using running buffer to which up to $500 \mathrm{mM}$ imidazole $(\mathrm{v} / \mathrm{v})$ was added. The tags were removed by overnight digestion with either bovine thrombin (Sigma-Aldrich) or ULP-1 protease and the samples loaded into a MonoQ 5/50 GL anion exchange chromatography column (GE Healthcare). Elution was done by performing a linear gradient with a buffer containing $1 \mathrm{M} \mathrm{NaCl}, 30 \mathrm{mM}$ Tris- $\mathrm{HCl} \mathrm{pH} 7.5$ and $2 \mathrm{mM}$ BME. The fractions containing the protein of interest were loaded into a HiLoad 16/600 Superdex 75 size-exclusion column (GE Healthcare), equilibrated with $30 \mathrm{mM}$ Tris- $\mathrm{HCl}, \mathrm{pH} 7.5,150 \mathrm{mM} \mathrm{NaCl}$ and $0.5 \mathrm{mM}$ TCEP (tris(2-carboxyethyl)phosphine). Protein concentrations were determined by UV $280 \mathrm{~nm}$ using calculated extinction coefficients.

Crystallization. Size-exclusion purified PASb-3 $\alpha$ was concentrated down with an Amicon ultrafiltration device (10 KDa cutoff; Millipore) to a final concentration of approximately $300 \mu \mathrm{M}$. Crystallization experiments were performed at $291 \mathrm{~K}$ using the conventional sitting drop vapor diffusion technique. Drops were made by mixing equal parts of protein and well solution, containing 3\% PEG 400, $1.9 \mathrm{M}$ Amonium Sulphate, 0.1 M Sodium Acetate pH 5.7. Small bar-shaped crystals started growing two days after the setting up of the crystallization drops, reaching about $50 \mu \mathrm{M}$ in longest dimension on average usually after 5 days. Before data collection at cryogenic temperature $(100 \mathrm{~K})$, harvested crystals were cryoprotected with $10 \%$ ethylene glycol added to the mother liquor (v/v).

X-ray crystallography. X-ray diffraction data sets were obtained at the P13 beamline at PETRA III, Hamburg, Germany. Data was processed using Mosflm ${ }^{21}$ and merged and scaled with Aimless ${ }^{22}$. The first set of phases was obtained by the molecular replacement as implemented in the program Phaser ${ }^{23}$, using the PASb domain of HIF-1 $\alpha$ (PDB ID $4 \mathrm{~h} \mathrm{j}^{9}$ ) as a search model. Positional and anisotropic B-factor refinement cycles were carried out with Phenix ${ }^{24}$. Manual building of the extra portions and real space refinement, including Fourier electron density map inspection, were performed with $\operatorname{Coot}^{25}$. Solvent water molecules, treated as oxygen atoms, were added using the appropriate Coot routine. The survey for cavities was done using KVFinder ${ }^{26}$. During model refinement, the inspection of Fourier difference maps indicated the presence of very strong non-protein electron densities (over $3 \sigma$ in height in the $\mathrm{F}_{\mathrm{obs}}-\mathrm{F}_{\text {calc }}$ Fourier maps) that were interpreted - due to their sizes and shapes and in respect with the crystallization condition - as two 1-11Z-vaccenoyl-sn-glycerol molecules, five PEG 400 molecules and two sulfate ions, all subsequently refined as such. Two additional strong electron density distributions also resembling PEG400 molecules were found on the vicinities of Tyr264 in chain A and Trp315 in chain B. The refinement of such molecules, however, did not converge after many modeling configurations and the densities were then left as unexplained. The overall stereochemical quality of the final models and the agreements between them and experimental data were assessed by the program Molprobit ${ }^{27}$ and the appropriate Phaser and Coot routines.

Thin-layer chromatography. Chromatographic separations were carried out on $4 \times 2 \mathrm{~cm}$ TLC Silica gel $60 \mathrm{~F}_{254}$ aluminum plates (Merck). The complex lipid mixture was applied on the edge of the plates (at the sample spotting line) using a glass capillary. The samples were allowed to run for $4 \mathrm{~cm}$ in a $8 \times 4 \mathrm{~cm}$ glass chamber, previously saturated with the mobile phase. Two distinct mobile phases were used cyclohexane:ethyl acetate (4:1) and chloroform:methanol:water (75:25:2.5) - which respectively allow for the separation of neutral lipids and the separation of phospholipids by head group polarity. The plates were then left exposed to air to allow for evaporation of the mobile phase residual. For differential detection of neutral lipids and phosphorous-containing lipids, iodine vapor and a modified Dittmer-Lester reagent ${ }^{13}$ were employed for dual staining. The plates were scanned immediately after drying. 
Mass spectrometry. Lipids were extracted from $400 \mu \mathrm{L}$ of purified protein $\left(\sim 1 \mathrm{mg} \cdot \mathrm{ml}^{-1}\right)$ using $1 \mathrm{~mL}$ of a precooled $\left(-15^{\circ} \mathrm{C}\right)$ mixture of MTBE: methanol: water 3:1:1 (v/v/v) as previously described ${ }^{28,29}$. Five hundred microliters of the upper phase, containing the lipids, were transferred to a fresh $1.5 \mathrm{ml}$ Eppendorf tube and dried down in a speed-vac. The extracts that were reconstituted in acetonitrile: isopropanol $7: 3(\mathrm{v} / \mathrm{v})$ (final concentration $25 \mu \mathrm{g} \cdot \mathrm{ml}^{-1}$ ) were gradient-eluted on an UPLC-system (Accela, Thermo) using a reverse phase C8 column ACQUITY UPLC BEH $1.7 \mu \mathrm{m}, 2.1 \times 150 \mathrm{~mm}$ (Waters, 186003377). The gradient of separation was done at $400 \mu \mathrm{L} \cdot \mathrm{min}^{-1}$ using (A) $0.1 \%$ acetic acid in water and (B) $0.1 \%$ acetic acid in methanol (60\% B during $4 \mathrm{~min}, 60 \% \mathrm{~B}$ to $80 \%$ B in $4 \mathrm{~min}, 80-99 \%$ B in $0.5 \mathrm{~min}, 99 \% \mathrm{~B}$ for $3.5 \mathrm{~min}$ ). The samples were measured in negative ion mode and mass spectra were acquired using an LTQXL mass spectrometer (MS) (ThermoFisher Corporation) with electrospray ionization (ESI). The MS interface capillary was maintained at $325^{\circ} \mathrm{C}$, with a sheath gas flow of 45 (arbitrary units) and auxiliary gas flow of 2 (arbitrary units) for negative injections. The spray voltage ion injection was $4 \mathrm{kV}$, and the instrument scanned 350-600 m/z. MS/MS normalized collision energy was set to 41 , activation Q 0.25 , activation time $30 \mathrm{~ms}$, and a $2 \mathrm{~m} / \mathrm{z}$ isolation window. MS/MS scans were collected using dynamic exclusion with an exclusion time of $30 \mathrm{~s}$. Obtained raw-chromatograms were further processed using Excalibur software version 2.10 (Thermo Fisher). The MS/MS scores are based on a comparison of the ions present in the experimental spectrum to the ions present in the standard library spectrum from the Lipid Mass Database ${ }^{30,31}$.

Fluorescence polarization. Purified PASb-1 $\beta$ was labeled with the FITC fluorophore (fluorescein isothiocyanate, Thermo Scientific) by mixing $1 \mathrm{mg}$ of protein with 20 -fold molar excess of FITC in $50 \mathrm{mM}$ borate buffer $\mathrm{pH} 8.5$ for 1 hour at room temperature on the dark. The excess FITC was removed by overnight dialysis at $4{ }^{\circ} \mathrm{C}$ with $30 \mathrm{mM}$ Hepes $\mathrm{pH} 7.5,150 \mathrm{mM} \mathrm{NaCl}$ and $0.5 \mathrm{mM}$ TCEP. Unlabeled PASb- $1 \alpha$ and PASb-3 $\alpha$, initially at a concentration of approximately $1 \mathrm{mM}$, were serially diluted $1: 2$ nineteen consecutive times into buffer $30 \mathrm{mM}$ Hepes $\mathrm{pH} 7.5,150 \mathrm{mM} \mathrm{NaCl}$ and $0.5 \mathrm{mM}$ TCEP. Then, $18.75 \mu \mathrm{L}$ from each protein dilution was mixed with $6.25 \mu \mathrm{L}$ of PASb- $1 \beta$ labeled with FITC at $80 \mathrm{nM}$ (final concentration of labeled protein was fixed at $20 \mathrm{nM}$ ). A final reaction volume of $25 \mu \mathrm{L}$ was pipetted into a 384-well black-walled microplate (Greiner Bio-one), in triplicate. Protein:protein complex samples were incubated at room temperature in the dark and fluorescence polarization (FP) was measured in a CLARIOstar microplate reader (BMG Labtech) with excitation and emission wavelengths of $480 \mathrm{~nm}$ and $520 \mathrm{~nm}$, respectively. Experimental values were output as mean \pm standard deviation and logistic sigmoidal curves fitted to determine dissociation constants $\left(\mathrm{K}_{\mathrm{d}}\right)$ for each protein:protein complex interaction.

Lipid binding assay. Removal of bacterial lipids from purified PASb- $3 \alpha$ was reached by protein incubation $\left(1.7 \mathrm{~mL}\right.$ at $10 \mathrm{uM}$ ) with $100 \mathrm{mg}$ of LIPIDEX 1000 (Sigma Aldrich) for $1 \mathrm{~h}$ at $37^{\circ} \mathrm{C}$ in buffer containing $30 \mathrm{mM}$ Tris $\mathrm{pH} 7.5,150 \mathrm{mM} \mathrm{NaCl}$ and $0.5 \mathrm{mM}$ TCEP, for three to five consecutive times. After delipidation the protein was incubated with different fatty acids for binding assay using the fluorescent probe 8-Anilino-1-naphthalenesulfonic acid (1,8-ANS). The final protein concentration used in the measurements was around $1 \mu \mathrm{M}$, with $10 \mu \mathrm{M}$ of ANS. The fatty acid solutions, at initial concentration of $33 \mu \mathrm{M}$ in pure ethanol, were diluted in ethanol by serially diluted 1:3 twelve consecutive times. The concentration of ethanol in the final reaction never exceeded $1 \%$. The fluorescence measurements were recorded on a EnSpire multimode plate reader (Perkin Elmer) using a 96-well black-walled plate (Perkin Elmer), with excitation wavelength of $380 \mathrm{~nm}$ and emission wavelength range of $400-600 \mathrm{~nm}$, at $25^{\circ} \mathrm{C}$.

Isotopic labeling of PASb-1 $\beta$. To prepare ${ }^{15} \mathrm{~N}$ - and ${ }^{13} \mathrm{C} /{ }^{15} \mathrm{~N}$-labelled PASb-1 $\beta$, Escherichia coli Rosetta II cells were allowed to grow in a modified M9 minimal medium ${ }^{32}$ supplemented with $1 \mathrm{~g}$. $\mathrm{L}^{-1}{ }^{15} \mathrm{NH}_{4} \mathrm{Cl}$ (Cambridge Isotope Laboratories) combined with $4 \mathrm{~g} . \mathrm{L}^{-1} \mathrm{D}(+)$-glucose (Sigma) to obtain only ${ }^{15} \mathrm{~N}$-labelled proteins or with $\left[{ }^{13} \mathrm{C} 6\right]-\mathrm{D}(+)$-glucose (Cambridge Isotope Laboratories) to obtain double-labeled proteins. Expression and purification of labeled PASb-1 $\beta$ was performed using the same procedure as described for the unlabeled protein.

NMR spectroscopy. ${ }^{15} \mathrm{~N}$ - and ${ }^{13} \mathrm{C} /{ }^{15} \mathrm{~N}$-labeled PASb- $1 \beta$ was produced and purified in a final buffer containing $30 \mathrm{mM} \mathrm{Na}_{2} \mathrm{HPO}_{4}-\mathrm{NaH}_{2} \mathrm{PO}_{4} \mathrm{pH} 7.2,70 \mathrm{mM} \mathrm{NaCl}, 0.5 \mathrm{mM}$ TCEP and $10 \% \mathrm{D}_{2} \mathrm{O}$. NMR experiments were performed using an Agilent Inova spectrometer, operating at a ${ }^{1} \mathrm{H}$ Larmor frequency of $599.887 \mathrm{MHz}$ and temperature of $298 \mathrm{~K}$. The spectrometer is equipped with a triple resonance cryogenic probe and a $\mathrm{Z}$ pulse-field gradient unit. The spectra were processed with NMRPipe/NMRDraw ${ }^{33}$ and analyzed with NMRView ${ }^{34}$. The ${ }^{15} \mathrm{NHSQC}$ spectra of PASb-1 $\beta$ was collected and analyzed based on a previously deposited set of assigned chemical shifts into a public database at BioMagResBank (BMRB Entry 6597 ) and confirmed using the three-dimensional experiments HNCACB, CBCA $(\mathrm{CO}) \mathrm{NH}, \mathrm{HNCO}$, and $\mathrm{HN}(\mathrm{CA}) \mathrm{CO}^{35-38}$. PASb- $1 \alpha$ and PASb- $3 \alpha$, both initially at $900 \mu \mathrm{M}$, were titrated in ${ }^{15} \mathrm{~N}$-labeled PASb- $1 \beta$ $(200 \mu \mathrm{M})$, followed by the recording of the two-dimensional ${ }^{15}$ NHSQC spectra. Binding of proteins was characterized by changes in ${ }^{15}$ NHSQC signals, intensities and chemical shift values, as a function of the concentration of unlabeled protein. The chemical shift perturbation of the ${ }^{15} \mathrm{~N}-\mathrm{HSQC}$ spectra was normalized according to the equation $\Delta \delta\left({ }^{15} \mathrm{~N}+{ }^{1} \mathrm{H}\right)=\left[\left(\Delta \delta^{15} \mathrm{~N} / 10\right)^{2}+\left(\Delta \delta^{1} \mathrm{H}\right)^{2}\right]^{1 / 2}$, in ppm units ${ }^{39}$ and the relative peak intensity changes calculated using the equation $\left(\mathrm{I}-\mathrm{I}_{0}\right) / \mathrm{I}_{0}$, where $\mathrm{I}$ is the peak intensity 
measured in the presence of the maximum amount of unlabeled protein and $\mathrm{I}_{0}$ is the peak intensity measured in the free labeled protein.

Molecular Modelling of PASb-304. Ab initio homology modelling of PASb domain of HIF-3 $\alpha 4$, or PASb-3 44 (Gly237-Pro351, Uniprot Q9Y2N7-4) was done using methodology implemented by I-TASSER $^{40}$. The top output model was used for comparison against the crystallographic model of lipid-bound PASb-3 $\alpha$.

Tissue array. Human normal and tumor tissue arrays containing 78 normal tissue spots (FDA805-1, U.S. Biomax) or 18 normal tissues and 54 tumors (FDA805-2, U.S. Biomax) from multiple organs were subjected to immunohystochemical analysis with Anti-HIF3 alpha antibody (ab10134, Abcam). The tissue array slides were deparaffinized by two xylene washes $(10 \mathrm{~min}$ each) and then rehydrated in ethanol series. After washing with water, the slides were microwaved for 10 rounds of $1 \mathrm{~min}$ in $10 \mathrm{mM}$ sodium citrate buffer ( $\mathrm{pH}$ 6.0) and allowed to cool to room temperature to retrieve antigens. Endogenous peroxidase activity was extinguished after $30 \mathrm{~min}$ incubation in $0.3 \% \mathrm{H}_{2} \mathrm{O}_{2}$ in PBS. The slides were then blocked with Avidin and Biotin blocking solutions (Avidin/Biotin Blocking Kit; Vector Labs) and 1\% goat serum in PBS (Vectastain Elite ABC Kit, Vector Labs). The tissue arrays were incubated overnight with the primary antibody (1:100 dilution in $1 \mathrm{X}$ PBS, $0.2 \%$ BSA, $0.02 \%$ Triton X-100, $10 \mathrm{mM}$ Glycine), washed in same buffer, incubated with biotinylated secondary antibody 1:200 and treated for $30 \mathrm{~min}$ with the Elite $\mathrm{ABC}$ reagent (Universal R.T.U. Vectastain Elite ABC Kit; Vector Labs). After washing with PBS, the slides were processed with chromogen solution (ImmPACT DAB Substrate; Vector Labs). The slides were then dehydrated by ethanol series and mounted using Entellan New (Merck). The resulting staining obtained were captured using Operetta (PerkinElmer) 2X magnification objective, stitched by Harmony software (PerkinElmer) and quantified using ImageJ software. To allow comparison between slides, all data was normalized first to Skin Malignant melanoma spot (present in both slides). A second normalization was done to the highest expression in each specific tissue type. Samples were selected based on $n \geq 2$ and the simultaneous presence of both normal and cancer representatives. Statistical significance was tested using Two-sample t-test, considering $\mathrm{p}<0.1$.

TCGA data analysis. All the gene-expression data derived from RNA-seq were downloaded from The Cancer Genome Atlas data portal (http://tcga-data.nci.nih.gov/tcga/dataAccessMatrix.htm). For the evaluation of HIF- $3 \alpha 9$ expression levels across tumor types, the normalized RSEM count from uc002peh.2 were used. For tumors with mean expression above 5, the 2-component Gaussian mixture distribution model with fixed variance for definition of expressing and non-expressing patients ${ }^{41,42}$ was implemented using mclust ${ }^{43}$ package ( $\mathrm{R}$ statistical software ${ }^{44}$ ) and fitted independently for each tumor dataset using the uc002peh.2 expression levels. Patients were categorized in each class and gene differential expression analysis was performed using $\mathrm{EBSeq}^{45}$ package ( $\mathrm{R}$ statistical software) using as input raw RSEM values and performing a $75 \mathrm{~h}$ quantile normalization ${ }^{46}$. Genes up- $(>1)$ and down- regulated $(<1)$ with posterior probability of being differentially expressed above 0.95 were used as input for KOBAS2. $0^{47}$ pathway enrichment analysis for REACTOME database. The Venn plot were made with VennDiagram ${ }^{48}$ package ( $\mathrm{R}$ statistical software).

Canonical ensemble simulation of lipid in vacuum. A Metropolis-Monte Carlo simulation was performed to recapitulate a canonical ensemble for the free stearic, oleic and linoleic acids. One-million-steps simulation, as implemented in Python, was performed, with temperature set to $300 \mathrm{~K}$. The associated energies of randomly generated microstates was calculated using YASARA's function Energy("All”) ${ }^{49}$ and the AMBER03 force field ${ }^{50}$ for the parametrization of the lipid molecules. Probability of micro-states $\mathrm{P}(\mathrm{s})$ were calculated by discretization of Boltzmann distributions using hist(Energy)\$density function of the statistical software $\mathrm{R}^{44}$. Entropy was estimated with $\mathrm{S}($ lipid,vacuum $)=\mathrm{P}(\mathrm{s}) \cdot \log (\mathrm{P}(\mathrm{s}))$.

\section{References}

1. Semenza, G. L. Oxygen sensing, hypoxia-inducible factors, and disease pathophysiology. Annu Rev Pathol 9, 47-71 (2014).

2. Maynard, M. A. et al. Multiple splice variants of the human HIF-3 $\alpha$ locus are targets of the von Hippel-Lindau E3 ubiquitin ligase complex. J Biol Chem 278, 11032-11040 (2003).

3. Pasanen, A. et al. Hypoxia-inducible factor (HIF)-3 $\alpha$ is subject to extensive alternative splicing in human tissues and cancer cells and is regulated by HIF-1 but not HIF-2. Int J Biochem Cell Biol 42, 1189-1200 (2010).

4. Zhang, P. et al. Hypoxia-inducible factor 3 is an oxygen-dependent transcription activator and regulates a distinct transcriptional response to hypoxia. Cell Rep 6, 1110-1121 (2014)

5. Maynard, M. A. et al. Human HIF-3 $\alpha 4$ is a dominant-negative regulator of HIF-1 and is down-regulated in renal cell carcinoma. FASEB J 19, 1396-1406 (2005).

6. Partch, C. L., Card, P. B., Amezcua, C. A. \& Gardner, K. H. Molecular basis of coiled coil coactivator recruitment by the aryl hydrocarbon receptor nuclear translocator (ARNT). J Biol Chem 284, 15184-15192 (2009).

7. Partch, C. L. \& Gardner, K. H. Coactivators necessary for transcriptional output of the hypoxia inducible factor, HIF, are directly recruited by ARNT PAS-B. Proc Natl Acad Sci USA 108, 7739-7744 (2011).

8. Henry, J. T. \& Crosson, S. Ligand-binding PAS domains in a genomic, cellular, and structural context. Annu Rev Microbiol 65 , 261-286 (2011).

9. Cardoso, R. et al. Identification of Cys255 in HIF-1 $\alpha$ as a novel site for development of covalent inhibitors of HIF-1 $\alpha /$ ARNT PasB domain protein-protein interaction. Protein Sci 21, 1885-1896 (2012). 
10. Scheuermann, T. H. et al. Artificial ligand binding within the HIF2alpha PAS-B domain of the HIF2 transcription factor. Proc Natl Acad Sci USA 106, 450-455 (2009).

11. Rogers, J. L. et al. Development of inhibitors of the PAS-B domain of the HIF-2 $\alpha$ transcription factor J. Med. Chem. 56, 1739-1747 (2013).

12. Scheuermann, T. H. et al. Allosteric inhibition of hypoxia inducible factor-2 with small molecules. Nat Chem Biol 9, 271-276 (2013).

13. Dyńska-Kukulska, K., Ciesielski, W. \& Zakrzewski, R. The use of a new, modified Dittmer-Lester spray reagent for phospholipid determination by the TLC image analysis technique. Biomed Chromatogr 27, 458-465 (2013).

14. Cronan, J. E. \& Vagelos, P. R. Metabolism and function of the membrane phospholipids of Escherichia coli. Biochim Biophys Acta 265, 25-60 (1972).

15. Glatz, J. F. \& Veerkamp, J. H. Removal of fatty acids from serum albumin by Lipidex 1000 chromatography. J Biochem Biophys Methods 8, 57-61 (1983).

16. Hoff, W. D. et al. Global conformational changes upon receptor stimulation in photoactive yellow protein. Biochemistry $\mathbf{3 8}$, 1009-1017 (1999).

17. Kroon, A. R. et al. Spectral tuning, fluorescence, and photoactivity in hybrids of photoactive yellow protein, reconstituted with native or modified chromophores. J Biol Chem 271, 31949-31956 (1996).

18. Pandini, A., Denison, M. S., Song, Y., Soshilov, A. A. \& Bonati, L. Structural and functional characterization of the aryl hydrocarbon receptor ligand binding domain by homology modeling and mutational analysis. Biochemistry 46, 696-708 (2007).

19. Katschinski, D. M. et al. Interaction of the PAS B domain with HSP90 accelerates hypoxia-inducible factor-1alpha stabilization. Cell Physiol Biochem. 15, 351-360 (2004).

20. Dick, K. J. et al. DNA methylation and body-mass index: a genome-wide analysis. Lancet 383, 1990-1998 (2014).

21. Leslie, A. G. Recent changes to the MOSFLM package for processing film and image plate data. Joint CCP4+ESF-EAMCB Newsletter on Protein Crystallography 26, 27-33 (1992).

22. Evans, P. R. \& Murshudov, G. N. How good are my data and what is the resolution? Acta Crystallogr D Biol Crystallogr 69, 1204-1214 (2013)

23. McCoy, A. J. et al. Phaser Crystallographic software. J Appl Cryst 40, 658-674 (2007).

24. Adams, P. D. et al. PHENIX: a comprehensive Python-based system for macromolecular structure solution. Acta Crystallogr D Biol Crystallogr 66, 213-221 (2010).

25. Emsley, P., Lohkamp, B., Scott, W. G. \& Cowtan, K. P. Features and development of Coot. Acta Crystallogr D Biol Crystallogr 66, 486-501 (2010).

26. Oliveira, S. H. et al. KVFinder: steered identification of protein cavities as a PyMOL plugin. BMC Bioinformatics Jun 15, 197 (2014).

27. Chen, V. B. et al. MolProbity: all-atom structure validation for macromolecular crystallography. Acta Crystallogr D Biol Crystallogr 66, 12-21 (2010).

28. Giavalisco, P. et al. Elemental formula annotation of polar and lipophilic metabolites using (13)C, (15)N and (34)S isotope labelling, in combination with high-resolution mass spectrometry. Plant J 68, 364-376 (2011).

29. Hummel, J. et al. Ultra performance liquid chromatography and high resolution mass spectrometry for the analysis of plant lipids. Front Plant Sci 2, 54 (2011).

30. Fahy, E., Sud, M., Cotter, D. \& Subramaniam S. LIPID MAPS online tools for lipid research. Nucleic Acids Res 35, W606-12 (2007).

31. Fahy, E. et al. LIPID MAPS comprehensive classification system for lipids. J Lipid Res 50, S9-S14 (2009).

32. Li, M. X., Corson, D. C. \& Sykes B. D. Structure determination by NMR: isotope labeling. Methods Mol Biol 173, 255-265 (2002).

33. Delaglio, F. et al. NMRPipe: A multidimensional spectral processing system based on UNIX pipes. J Biomol NMR 6, 277-293 (1995).

34. Johnson, B. \& Blevins, R. NMR View: A computer program for the visualization and analysis of NMR data. J Biomol NMR 4, 603-614 (1994).

35. Ikura, M., Kay, L. \& Bax, A. A novel approach for sequential assignment of $1 \mathrm{H}, 13 \mathrm{C}$, and $15 \mathrm{~N}$ spectra of larger proteins: Heteronuclear triple-resonance three-dimensional NMR spectroscopy. Application to calmodulin. Biochemistry 29, 4659-4667 (1990).

36. Grzesiek, S. \& Bax, A. Amino acid type determination in the sequential assignment procedure of uniformly $13 \mathrm{C} / 15 \mathrm{~N}$-enriched proteins. J Biomol NMR 3, 185-204 (1993).

37. Wittekind, M. \& Mueller, L. HNCACB, a high-sensitivity 3D NMR experiment to correlate amide-proton and nitrogen resonances with the alpha- and beta-carbon resonances in proteins. J Magn Reson Ser B 101, 201-205 (1993).

38. Yamazaki, T., Lee, W., Arrowsmith, C., Muhandiram, D. R. \& Kay, L. E. A suite of triple resonance NMR experiments for the backbone assignment of 15N, 13C, 2H labeled proteins with high sensitivity. I Am Chem Soc 116, 11655-11666 (1994).

39. Cavanagh, J., Fairbrother, W., Palmer, A., III, Rance, M. \& Skelton, N. Protein NMR Spectroscopy: Principles and Practice (Academic Press, San Diego, 2007).

40. Roy, A., Kucukural, A. \& Zhang, Y. I-TASSER: a unified platform for automated protein structure and function prediction. Nat Prot 5, 725-738 (2010).

41. Lehmann, B. D. et al. Identification of human triple-negative breast cancer subtypes and preclinical models for selection of targeted therapies. J Clin Invest 121, 2750-2767 (2011).

42. Curtis, C. et al. The genomic and transcriptomic architecture of 2,000 breast tumours reveals novel subgroups. Nature 486, 346-52 (2012).

43. Fraley, C. \& Raftery, A. E. Model-based Clustering, Discriminant Analysis and Density Estimation. J Am Stat Assoc 97, 611-631 (2002).

44. Ihaka, R. \& Gentleman, R. R: A language for data analysis and graphics. J Comput Graph Stat 5, 299-314 (1996).

45. Anders, S. \& Huber, W. Differential expression analysis for sequence count data. Genome Biol. 11, R106 (2010) Genome Biol 11, R106 (2010).

46. Bullard, J. H., Purdom, E., Hansen, K. D. \& Dudoit, S. Evaluation of statistical methods for normalization and differential expression in mRNA-Seq experiments. BMC Bioinformatics 11, 94 (2010). BMC Bioinformatics 11, 94 (2010).

47. Xie, C. et al. KOBAS 2.0: A web server for annotation and identification of enriched pathways and diseases. Nucleic Acids Res 39, 316-322 (2011).

48. Chen, H. \& Boutros, P. C. VennDiagram: a package for the generation of highly-customizable Venn and Euler diagrams in R. BMC Bioinformatics 12, 35 (2011).

49. Krieger, E., Darden, T., Nabuurs, S., Finkelstein, A. \& Vriend, G. Making optimal use of empirical energy functions: force-field parameterization in crystal space. Proteins 57, 678-683 (2004).

50. Duan, Y. et al. Point-Charge Force Field for Molecular Mechanics Simulations of Proteins. J Comput Chem 24, 1999-2012 (2003). 


\section{Acknowledgements}

This work was supported by the São Paulo State Research Foundation, FAPESP, under grants 2012/14298-9 and 2014/20673-2 (to ALBA) and 2014/15968-3 (to SMGD), and fellowships 2010/13739-6 and 2014/04927-4 (to AMF). We thank LNBio for financial support and access to facilities (LPP, MAS, LBE, NMR and Robolab). We thank Dr. Alessandra Girasole for expert technical and secretarial support. We are very grateful to Dr. Chi Van Dang and Zandra Walton (Abramson Cancer Center, University of Pennsylvania, USA) for expert comments and suggestions as well as stimulating discussions. We are also grateful to Dr. Richard Charles Garratt (IFSC/USP, Brazil) for detailed and critical reading of the manuscript. The results published here are part based upon data generated by the TCGA Research Network: http://cancergenome.nih.gov/.

\section{Author Contributions}

A.M.F., J.F.O., S.M.G.D. and A.L.B.A. designed research; A.M.F., J.F.O., D.A., J.A., S.A.R., M.M.D., M.V.B.D., M.L.S. and P.S.L.O. performed research; A.M.F., J.F.O., D.A., J.A., S.A.R., M.M.D., M.V.B.D., M.L.S., P.S.L.O., C.C., S.M.G.D. and A.L.B.A. analyzed and discussed data; S.M.G.D. and A.L.B.A. wrote the paper.

\section{Additional Information}

Supplementary information accompanies this paper at http://www.nature.com/srep

Competing financial interests: The authors declare no competing financial interests.

How to cite this article: Fala, A.M. et al. Unsaturated fatty acids as high-affinity ligands of the C-terminal Per-ARNT-Sim domain from the Hypoxia-inducible factor 3a. Sci. Rep. 5, 12698; doi: 10.1038/srep12698 (2015).

(c) (i) This work is licensed under a Creative Commons Attribution 4.0 International License. The images or other third party material in this article are included in the article's Creative Commons license, unless indicated otherwise in the credit line; if the material is not included under the Creative Commons license, users will need to obtain permission from the license holder to reproduce the material. To view a copy of this license, visit http://creativecommons.org/licenses/by/4.0/ 
Human mitochondrial pyruvate carrier 2 as an autonomous and selective transporter

Raghavendra Sashi Krishna Nagampalli ${ }^{1 * *}$, José Edwin Neciosup Quesñay ${ }^{1, *}$, Douglas Adamoski ${ }^{1, *}$, Zeyaul Islam ${ }^{1}$, James Birch ${ }^{2,3}$, Heitor Gobbi Sebinelli ${ }^{4}$, Carolline Fernanda Rodrigues Ascenção ${ }^{1}$, Angela Maria Fala ${ }^{1}$, Bianca Alves Pauletti ${ }^{1}$, Sílvio Roberto Consonni ${ }^{1 \ddagger}$, Juliana Ferreira Oliveira ${ }^{1}$, Amanda Cristina Teixeira Silva ${ }^{1}$, Kleber Gomes Franchini ${ }^{1}$, Adriana Franco Paes Leme ${ }^{1}$, Pietro Ciancaglini $^{4}$, Isabel Moraes ${ }^{2,3}$, Sandra Martha Gomes Dias ${ }^{1} \uparrow \&$ Andre Luis Berteli Ambrosio ${ }^{1} \uparrow$

From the ${ }^{1}$ Laboratório Nacional de Biociências, Centro Nacional de Pesquisa em Energia e Materiais, Campinas, SP, 13083-970, Brazil; the ${ }^{2}$ Membrane Protein Laboratory, Diamond Light Source, Harwell

Science and Innovation Campus, Didcot, Oxfordshire OX11 0DE, England; ${ }^{3}$ Research Complex at Harwell, Rutherford Appleton Laboratory, Harwell, Didcot, Oxfordshire OX11 0FA, England; the ${ }^{4}$ Departamento de Química, Faculdade de Filosofia, Ciências e Letras de Ribeirão Preto, Universidade de São Paulo, Ribeirão Preto, SP, 14040-901, Brazil.

*RSKN, JENQ and DA contributed equally to this work.

*current address: Departamento de Bioquímica e Biologia Tecidual, Instituto de Biologia, Universidade Estadual de Campinas, Campinas, SP, 13083-862, Brazil.

$\uparrow$ To whom correspondence may be addressed: Sandra MG Dias or Andre LB Ambrosio, Laboratório Nacional de Biociências (LNBio), Centro Nacional de Pesquisa em Energia e Materiais (CNPEM), Rua Giuseppe Máximo Scolfaro, 10.000, Pólo II de Alta Tecnologia, Campinas, SP, 13083-970, Brazil. Tel: +55 193512 1115/Fax: +55 193512 1004; e-mail: andre.ambrosio@Inbio.cnpem.br

KEYWORDS: membrane protein, mitochondria, transporter, pyruvate carrier, MPC1, MPC2.

The active transport of glycolytic pyruvate across the human inner mitochondrial membrane is thought to involve two mitochondrial pyruvate carrier subunits, MPC1 and MPC2, assembled as a $150 \mathrm{kDa}$ oligomeric heterotypic structure. Here, the recombinant production of human MPC subunits through a co-expression strategy is described; however, substantial complex formation was not observed, and predominantly individual subunits were purified. In contrast to MPC1, which co-purifies with a host chaperone, we demonstrated that MPC2 promotes efficient pyruvate transport into reconstituted proteoliposomes. The derived functional requirements, kinetics and inhibition features of MPC2 resemble those previously demonstrated for pyruvate transport in mitochondrial extracts. Importantly, the ectopic expression of human MPC2 in yeast lacking endogenous MPC stimulated growth in culture media lacking valine and increased the consumption of oxygen, thus validating an autonomous role for MPC 2 in yeast cells. The presence of multiple oligomeric species of MPC2 in mitochondrial isolates, purified protein and in artificial lipid bilayers suggest functional dimers or high-order complexes. Significant changes in the secondary structure content of MPC2, as probed by synchrotron radiation circular dichroism, further supports the interaction between the protein and ligands. Our results provide the initial framework for exploring the independent role of MPC2 in homeostasis and diseases related to dysregulated pyruvate metabolism.

Nearly four decades after the demonstration of the protein-mediated transport of pyruvate across the inner mitochondrial membrane (IMM) (1), two concurrent studies identified the oligomeric complex formed by MPC1 and MPC2 as necessary and sufficient for this task $(2,3)$; MPC1 and MPC2 were proposed to function 
together via the formation of an oligomeric structure of approximately $150 \mathrm{kDa}(2)$. These original findings inspired many subsequent investigations that have further characterized MPCdependent pyruvate transport in the cellular context (4-6), with multiple groups showing that either the loss of MPC1 or MPC2 in mitochondria is sufficient to confer similar loss of function phenotypes (6-10). However, to date, the isolation and reconstitution of MPC1:MPC2 into proteoliposomes is still considered necessary to perform the ultimate proof-of-concept experiment to measure pyruvate transport $(10-12)$.

In this context, we report the first successful, large-scale, recombinant production and functional reconstitution of this family of carriers in an artificial lipid bilayer. We provide an unprecedented in vitro demonstration that human MPC2 functions independently of MPC1 to induce pyruvate transport, possibly as high-order oligomers. In cells, the ectopic expression of human MPC2 improved oxygen consumption and stimulated growth compared to yeast cells lacking endogenous MPC. Most importantly, these observations are consistent with those of early and recent publications, suggesting that mitochondrial pyruvate transport by MPC is a rapid and specific process that depends on co-proton import and redox balance and is sensitive to inhibition by a small molecule (13-16). Our findings open a discussion concerning pyruvate import regulation by at least two different molecular entities in human mitochondria: heterotypic MPC1:MPC2 and homotypic MPC2:MPC2. Our work also has immediate implications for the development of small-molecule-oriented therapeutics that specifically target MPC2 in pyruvate-related diseases such as cancer, Alzheimer's disease, and diabetes $(10,12,17-20)$.

\section{RESULTS}

Purification of recombinant MPC. Human MPC1 and MPC2 proteins were co-expressed from codonoptimized genes in a heterologous yeast system (Saccharomyces cerevisiae JRY472) that was modified to lack endogenous MPC $(\Delta m p c 1 / 2 / 3)$. This mutant strain is hereafter referred to as $3 \Delta(2)$. A bi-directional expression plasmid was initially engineered to contain MPC1 fused to an $8 \mathrm{xHis}$ tag and MPC2 linked to a cleavable monomeric GFP (Fig. 1A). This system enabled the detection of inducible expression levels and cellular compartmentalization as well as subsequent purification via cobalt-based immobilized metal affinity chromatography (Co-IMAC) of the target complex. Controlled expression (Supp. Fig. 1A) and proper mitochondrial localization of MPC were confirmed (Fig. 1A, left panel and Supp. Fig. 1B). n-Dodecyl- $\beta$-D-maltoside (DDM, at $1 \%$ ) was identified as a suitable detergent for the extraction of proteins from membrane pellets. The target proteins were purified via Co-IMAC, followed by gel-filtration chromatography (GF), both of which were carried out in the presence of $0.03 \%$ DDM (Fig. 1A, center panel). A sharp monodisperse peak was obtained after GF, which corresponded to a molecular weight of $64 \mathrm{kDa}$ for the proteindetergent complex (Fig. 1A, right panel). Surprisingly, the peak sample derived from human MPC1 was strongly associated with the yeast $60 \mathrm{~S}$ ribosomal protein L28 (both proteins and were further identified using mass spectrometry, Supplementary Table 1). In addition, traces of copurified, GFP-fused MPC2 were confirmed via silver staining and in-gel fluorescence (Fig. 1A, inset).

Intrigued by the trace amounts of human MPC2 isolated during the complete purification of MPC1, as well as the lower-than-expected molecular weight, we generated an alternative plasmid construct. In this new construct, the polyhistidine tag from MPC1 was transferred to the Cterminus of the MPC2-GFP fusion (Fig. 1B), similar to a previously successful approach employed for other eukaryotic membrane proteins expressed in yeast (21). Upon confirmation of proper mitochondrial localization of the new construct (Fig. 1B, left panel), the recombinant proteins were successfully extracted with $1 \%$ C12E8 (octaethylene glycol monododecyl ether) and purified in the presence of $0.03 \%$ DDM via CoIMAC, followed by GFP-10xHis removal and GF (Fig. 1B, center panel). Again, a single monodisperse protein-detergent peak was obtained, which corresponded to a molecular weight of 70 $\mathrm{kDa}$ (Fig. 1B, right panel). This sample was shown to exclusively contain MPC2, which was then purified to homogeneity (Fig. 1B, center panel). 
Functional reconstitution of MPC in lipid vesicles. To evaluate the pyruvate transport activity of recombinant purified MPC in vitro, we reconstituted both purified protein products, individually and in combination, into asolectin liposomes (Supp. Fig. 2A-B) (22). Substrate uptake was quantified based on the observed decrease in extraliposomal pyruvate content, as indicated by the enzymatic activity of lactate dehydrogenase A (LDHA) (Supp. Fig. 2C). A pH gradient-dependent assay $(\Delta \mathrm{pH}=1.5)$ was derived in accordance with the chemical conditions recently established for mouse MPC (13). Notably, successful pyruvate transport activity was not observed for proteoliposomes reconstituted with MPC1 copurified with RPL28 and traces of MPC2 (termed MPC1*, Fig. 2A). By contrast, compared to protein-free liposomes, which were used as a control, proteoliposomes containing MPC2 alone showed significant pyruvate uptake $(47 \pm 2 \%)$ (Fig. 2A). Similarly, vesicles co-reconstituted with comparable levels of MPC1* and MPC2 (Supp. Fig. 2D) also induced the uptake of extraliposomal pyruvate; however, the corresponding transport levels were similar $(45 \pm 2 \%)$ to those obtained with MPC2 alone (Fig. 2A).

Most importantly, the self-sufficient role of human MPC2 in pyruvate transport was further supported when this protein was overexpressed and purified from a plasmid construct lacking the MPC1 coding sequence (Fig. 1C). As such, when reconstituted into proteoliposomes, this new construct (termed $\mathrm{MPC} 2^{* *}$ ) induced pyruvate transport across the bilayer at levels statistically similar (44 $\pm 2 \%$; Fig. $2 \mathrm{~A}$ ) to those mentioned above.

In vitro pyruvate transport is dependent on time and electrochemical gradient. Within a $\mathrm{pH}$ gradient of 1.5 units, MPC2 proteoliposomes induced rapid pyruvate transport. Pyruvate intake, which exhibited saturation kinetics, was proficient during the first $5 \mathrm{~min}$ of incubation, presenting halfmaximum efficiency after 1.3 min (Fig. 2B). Upon saturation, approximately $53 \pm 2 \%$ of the external substrate was incorporated into the proteoliposomes (Fig. 2B, given by the asymptote of the exponential decay model in blue).

The dependence of MPC2 activity on a proton electrochemical gradient was further confirmed upon proper calibration of LDHA activity (Supp. Fig. 2C). In a shallower $\mathrm{pH}$ gradient ( $\triangle \mathrm{pH} 0.8$ units), pyruvate transport reached $34 \pm 2$ $\%$ (Fig. 2C) compared with the $53 \pm 1 \%$ transported at a $\Delta \mathrm{pH}$ of 1.5 units. However, when the $\mathrm{pH}$ gradient collapsed $(\Delta \mathrm{pH}=0), 14 \pm 4 \%$ pyruvate transport was still measured (Fig. 2C), likely reflecting the chemical potential of pyruvate moving down its own concentration gradient.

In vitro pyruvate transport is sensitive to chemical inhibition, redox modification and substrate type. The previous landmark demonstration of the carrier-dependent transport of pyruvate across the IMM involved the identification of monocarboxylate mimetic cinnamates as effective and specific MPC inhibitors (1). In the present study, compared to the vehicle control (DMSO, 50 $\pm 2 \%)$, UK-5099, a potent cyanocinnamate $\left(K_{i} \approx 10\right.$ $\mathrm{nM}$ in mitochondrial extracts (23)), did not exert any significant inhibitory effect on in vitro MPC2dependent pyruvate transport ( $47 \pm 2 \%)$ when used at a final concentration of $50 \mu \mathrm{M}$, as shown in Fig. $3 \mathrm{~A}$.

Nevertheless, the inhibitory mechanism of cinnamates was originally shown to rely on a reversible Michael addition to a cysteine thiol group in MPC; loss of conjugation was achieved by the addition of reducing agents such as $\beta$ mercaptoethanol $(14,24)$. Here, although the complete elimination of TCEP (TRIS(2carboxyethyl)phosphine) from the early steps of membrane preparation up to proteoliposome reconstitution still permitted the standard purification of MPC2 (Supp. Fig. 3A), complete functional inactivation was observed (Fig. 3B). Reincubating MPC2 with TCEP at the stage of proteoliposome reconstitution resulted in the recovery of approximately three quarters $(32 \pm 2 \%)$ of the original activity ( $48 \pm 2 \%$, Fig. $3 \mathrm{~B})$.

To further explore the importance of redox modification on human MPC2 function, we generated a point mutant by replacing the single cysteine residue at position 54 with serine (Supp. Fig. 3B). Although the overall activity of the isosteric mutant (termed MPC2.C54S) was compromised ( $31 \pm 2 \%$ total transport), it was distinctly insensitive to TCEP (32 $\pm 2 \%$ total transport; Fig. 3C). Due to the lack of detectable MPC2 activity in the absence of TCEP $(2 \pm 2 \%$ 
total transport; Fig. 3B), combined with the observation that UK-5099 had no significant effect on the activity of proteoliposomes supplemented with TCEP (Fig. 3A), the true in vitro effects of cinnamates on MPC2 activity cannot be conclusively established. Noteworthily, MPC1, but not MPC2, was recently demonstrated to be the true target of cinnamates $(2,16)$. Together, however, these findings suggest that competent pyruvate transport also relies on a sulfhydryl-sensitive site on MPC2.

Thiazolidinedione (TZD) insulin sensitizers, such as rosiglitazone and pioglitazone, are commonly used to treat type 2 diabetes mellitus. This class of small molecules was also recently shown to inhibit pyruvate transport in cells at clinically relevant concentrations by directly and specifically targeting the MPC2 subunit $(16,18)$. In the present study, when compared to the vehicle control (DMSO, $50 \pm 2 \%$ ), rosiglitazone, at $50 \mu \mathrm{M}$, significantly decreased the MPC2-dependent internalization of pyruvate down to $28 \pm 2 \%$, as shown in Fig. 3A. The finding that a TZD derivative can decrease MPC2 activity has been substantiated by previous studies, further confirming the proteinmediated component of in vitro pyruvate transport $(16,18)$.

Finally, among all of the many carboxylates metabolized in the cell, lactate and pyruvate are directly linked and structurally similar. However, MPC2 is selective for pyruvate over lactate, as no detectable transport of the latter was observed over the range of concentrations tested and under the chemical conditions shown to be successful for pyruvate (Fig. 3D).

Ectopic human MPC2 expression stimulated growth and induced glucose-dependent respiration in yeast. The yeast strain JRY472 $(3 \Delta)$ used in the present study to produce recombinant human MPC, carries a mutation in the leu 2 gene and is therefore dependent on external leucine to grow. When cultured on synthetic dropout medium lacking valine but supplemented with leucine and threonine, this mutant strain grows with a doubling time of $53 \pm 1 \mathrm{~min}$ (Fig. 4A, filled green circles). Ectopic expression of human MPC2 in this strain, however, decreased the doubling time necessary by $16 \%$ (45 \pm 1 min; Fig. 4A, filled blue squares).
Accordingly, expression of the MPC2 isosteric mutant (C54S), with expected intermediary transport activity compared with wild-type MPC2, showed a $7 \%$ decrease in the doubling time of the same strain (50 $\pm 1 \mathrm{~min}$; filled red triangles in Fig. 4A). When cultured in synthetic medium supplemented with external valine, cells from all three groups (shown as open shapes in Fig. 4A) grew at similar levels to those for $3 \Delta+\mathrm{MPC} 2$ in the absence of valine. Therefore, the improved growth rates of $3 \Delta$ cells expressing human MPC2 might reflect the use of glycolytic pyruvate for biosynthetic purposes in the mitochondria, particularly for the production of valine.

The ability of human MPC2 to stimulate pyruvate-dependent respiration in yeast cells was also evaluated by quantifying oxygen consumption in response to the addition of $0.08 \%$ glucose to basal media. Whereas the mutant strain $3 \Delta$ responded to glucose addition with a slight, $10 \%$ increase in oxygen consumption over basal respiration $(1.1 \pm 0.1$-fold; filled green circles in Fig. 4), the same cells expressing human MPC2 responded to glucose addition with a $60 \%$ increase in oxygen consumption over basal respiration (1.6 \pm 0.1 -fold; filled blue squares in Fig. 4). Again, as expected, the ectopic expression of MPC2.C54S led to a reduced increase in oxygen consumption over basal levels $(1.3 \pm 0.1$-fold $)$ in response to glucose addition (filled red triangles in Fig. 4). To provide further evidence that all the added glucose was being oxidized via respiration, ethanol addition, which blocks residual fermentation, produced nearly the same response under all three test conditions (Fig. 4, open shapes). Taken together, these results further support the in vitro findings using artificial vesicles and, most importantly, confirm an autonomous role for MPC2 in promoting pyruvate transport.

Oligomeric nature and secondary structure composition of human MPC2. The lower-thanexpected molecular weight of the purified proteindetergent complex that was obtained above (Fig. $1 \mathrm{~B}-\mathrm{C})$, led us to further investigate the oligomeric assembly of the functional MPC2. First, by isolating the mitochondrial extracts (25), followed 
by short-range chemical cross-linking using disuccinimidyl suberate (DSS, $11.4 \AA$ linker), we observed the formation of MPC2 oligomers in its native lipid environment, starting from dimers up to higher-order molecular species, according to electrophoretic separation (Fig. 5A, left panel). When such experiment was performed with purified protein, only the presence of dimeric species was resolved, probably due to the association between the protein and the detergent (Fig. 5A, middle panel) (26). However, the subsequent reconstitution of purified MPC2 into proteoliposomes displayed the similar high-order, multi-species pattern that was observed in the mitochondrial extracts (Fig. 5A, right panel). This suggests that recombinant MPC2 in artificial lipid bilayer, which was proven functional for pyruvate transport, shares oligomeric similarities to the native mitochondrial membrane environment.

Lastly, in order to investigate the secondary structure composition of human MPC2, and to gauge the conformational changes due to binding of substrate and inhibitor, we performed synchrotron radiation circular dichroism (SRCD) analysis. SRCD indicated that this protein, in the absence of any ligands, is predominantly helical in nature (Fig. $5 \mathrm{~B}$, top left panel). The binding of pyruvate leads to improved structural stability, since the helical content is increased from $44 \%$ in the ligand-free control sample up to $56 \%$ when the substrate is present (Fig. 5B, top right panel); this might due to the fact that pyruvate needs to be transported across the channel of MPC2, by means of opening up or rearranging the structure. Conversely, the absence of TCEP lead to an overall increased disorder (Fig. $5 \mathrm{~B}$, bottom left panel), which is in agreement with the lack of in vitro transport activity under a similar condition (Fig. 3B). Notably, the addition of rosiglitazone had minor impact on the secondary structure composition of MPC2 (45\% versus $44 \%$ helices, respectively; Fig. 5B, bottom right panel), which could probably be associated with weak binding and thereby explaining its limited inhibitory effects on in vitro transport (Fig. 3B).

\section{DISCUSSION}

A rich body of evidence has established MPC1 and MPC2 as mandatory components for the mitochondrial uptake of pyruvate in both intact cells and mitochondrial isolates $(2,3,5,6,9,10$, 18). Co-immunoprecipitation from purified mitochondria, followed by electrophoretic separation, suggested that MPC1 and MPC2 form an oligomeric complex of approximately $150 \mathrm{kDa}$ (2). Here, we developed an experimental setup aimed at the co-expression and purification of recombinant human MPC as a heterocomplex. To this end, we used a bi-directional expression plasmid with inducible promoters that respond to galactose, such that both isoforms could be expressed simultaneously at high and similar levels. Moreover, we used a mutant yeast strain lacking the endogenous $m p c 1, m p c 2$ and $m p c 3$ genes (2) to avoid cross-contamination with yeast MPC.

Regardless, only the human MPC2 subunit was purified to homogeneity and shown to function in both in vitro and in vivo pyruvate transport. This finding was further confirmed when MPC2 was expressed without MPC1 and shown to be similarly functional. MPC1 co-purified with the yeast $60 \mathrm{~S}$ RPL28 protein and only traces of MPC2. In contrast to MPC2, MPC1 associated with 60S RPL28 was not active. These results suggest that yeast may lack some critical and yet unidentified protein component for stable complex formation of human MPC1:MPC2, as previously suggested (11). The existence of novel and direct interacting partners for MPC has been experimentally postulated $(27,28)$; moreover, a host non-membrane protein contaminant (60S RPL28) may act as a chaperone for human MPC1, potentially preventing detectable in vitro transport activity.

Collectively, the functional observations described above are consistent with previous and recent reports, suggesting that mitochondrial pyruvate transport by MPC is a rapid and specific process that depends on co-proton import and redox balance (13-15). Here, the finding that the in vitro MPC2 activity can be inhibited by a TZD derivative, albeit partially, is also substantiated by previous studies $(16,18)$. Of note, these functional parameters, which were proven essential for the demonstration of the protein-dependent pyruvate transport, are further reinforced by the circular dichroism studies using synchrotron radiation. 
However, the same purification and functional findings that indicate an autonomous role for MPC2 in pyruvate transport raise major questions about the need for a mandatory twocomponent heterotypic interaction for efficient pyruvate transport, as previously proposed. Notably, the dynamic stoichiometry of MPC subunits was recently shown to shift between hetero- and homo-oligomers in cells due to variations in both metabolic and tissue-related conditions $(6,10,29)$.

Here, the study of the oligomeric composition of recombinant MPC2 by chemical cross-linking in native (mitochondrial extracts) and native-like (asolectin vesicles) environments, further support the formation of large homotypic assemblies as the functional components, ranging hundreds of kilodaltons, as previously proposed for the heterotypic MPC1:MPC2 complex (2). The true size of the MPC2 oligomers, however, are yet to be determined.

Given all the potential scenarios described above, a major question remains: which physiological conditions promote MPC2-mediated pyruvate transport? Recently, MPC2 was shown to be strictly regulated by acetylation, which can critically determine the active or inactive states of this protein $(7,30-32)$; indeed, acetylation has been directly linked to decreased cellular oxygen consumption rates and deficient pyruvate transport activity (30). Deletion of MPC2 causes embryonic lethality in mice, indicating that this carrier subunit is particularly important for cell survival (33). We showed that human MPC2 alone can increase oxygen consumption in yeast cells driven by glucose addition and can rescue cell growth when valine is absent, suggesting that, in cells, human MPC2 facilitates mitochondrial pyruvate intake. This finding was further confirmed using the isosteric mutant. Curiously, MPC2 significantly increased oxygen consumption in the $3 \Delta$ mutant strain by $60 \%$; yet, compared with the control, MPC2 stimulated cell growth rates (measured as doubling time) by $16 \%$ in this strain. These results suggest that MPC2 may play a particular role in the distinct energetic and biosynthetic fates of pyruvate, which should be further investigated, perhaps in association to regulation by posttranslational modifications.
In conclusion, although the heterotypic MPC1:MPC2 component for transport was proposed based on a co-immunoprecipitation assay and yeast-based functional complementation assays (2), and despite the rapid increase in the literature regarding MPC pyruvate transport in the last 4-5 years, evidence regarding the direct interaction of these molecules has been lacking at the level of the isolated protein. Our work provides the first demonstration of the heterologous expression and purification of human MPC1 and MPC2. MPC2, but not MPC1, was purified to homogeneity and found to be active and sufficient for pyruvate transport in artificial liposomes and in cells.

\section{EXPERIMENTAL PROCEDURES}

Construct design and cloning. pBEVY-GU (34) (bi-directional expression vector for yeast, galactose inducible, URA3 selection) was a generous gift from Graham D. Pavitt (University of Manchester, UK). Standard molecular biology techniques were used to modify the original pBEVY-GU plasmid to add (i) the coding sequence for an $8 \mathrm{xHis}$ tag (with a four-amino acid spacer, VDGS) to the $3^{\prime}$ end of multiple cloning site 1 and (ii) a PreScission Protease recognition sequence, followed by EGFP at the 3 ' end of multiple cloning site 2. Codon-optimized, synthetic genes encoding human MPC1 (NCBI Reference Sequence: NP_057182.1) and MPC2 (NCBI Reference Sequence: NP_001137146.1) were acquired from GenScript, USA. The restriction sites Sall/BamHI and $\mathrm{XmaI} / \mathrm{EcoRI}$ were used to subclone $\mathrm{MPCl}$ and $M P C 2$, respectively. Standard techniques were also used to transfer the poly-histidine tag from the Cterminus of MPC1 to the C-terminus of EGFP. The additional constructs MPC1-mTFP+MPC2-GFP10xHis, MPC2 alone (plasmid construct devoid of the coding sequence for MPC1), and MPC2.C54S were generated using standard molecular biology techniques. The plasmids were propagated in TOP10 chemically competent bacteria (Thermo Fisher, USA).

Preparation of competent cells and transformation into yeast. The expression plasmids were transformed into a triple deletion mutant yeast strain (JRY2242, W303 mpc14mpc2Ampc34, his3 lys 2 met 15 trpl ura3) (2), kindly provided by Jared Rutter (University of Utah, USA). The procedure 
for transformation was adapted from a previously published protocol (35). Briefly, one yeast colony was inoculated into $5 \mathrm{~mL}$ of yeast peptone dextrose medium (YPD) and cultured overnight in an orbital shaker at $200 \mathrm{rpm}, 30{ }^{\circ} \mathrm{C}$. The following day, 0.8 $\mathrm{mL}$ of overnight culture was diluted into $30 \mathrm{~mL}$ of YPD in a 250-ml flask and grown as above until reaching an $\mathrm{OD}_{600}$ of 0.8 . The cells were centrifuged at $4,000 \mathrm{~g}$ for $10 \mathrm{~min}$ at $4{ }^{\circ} \mathrm{C}$, and the pellet was resuspended in $25 \mathrm{~mL}$ of sterile water. The centrifugation process was repeated, and the competent cells were initially resuspended in $1 \mathrm{~mL}$ and then $0.4 \mathrm{~mL}$ of $100 \mathrm{mM}$ lithium acetate. Subsequently, transformation was performed on ice, unless otherwise mentioned. To the $50 \mu \mathrm{L}$ of competent cells $240 \mu \mathrm{L}$ of $50 \%$ (w/v) PEG 3350 was added for each transformation. A total of $25 \mu \mathrm{l}$ of $2 \mathrm{mg} \cdot \mathrm{mL}^{-1}$ single-stranded carrier DNA was added to each tube and incubated for $5 \mathrm{~s}$. Subsequently, $50 \mu \mathrm{L}$ of DNA encoding human pyruvate carrier (100-150 ng) diluted in sterile water was added to each tube and incubated for $5 \mathrm{~s}$, followed by heat shock for $45 \mathrm{~min}$ at $42{ }^{\circ} \mathrm{C}$. The cells were centrifuged at $8,000 \mathrm{~g}$ for $1 \mathrm{~min}$ at RT, and the pellet was resuspended in $100 \mu \mathrm{L}$ of sterile water. The cell suspension was plated onto SDURA plates and incubated for 3 days at $30^{\circ} \mathrm{C}$.

Protein expression and purification. Typically, for large-scale overexpression of recombinant MPC, colonies from the SD-URA plates with the highest fluorescence levels were selected and used as preinoculum, with large-scale cultures (typically $4 \mathrm{~L}$ ) grown in shake flasks. Two hundred-milliliter cell cultures (in $500 \mathrm{~mL}$ flaks) transformed with MPC plasmids were grown overnight in YPD (2\% glucose) with shaking at $200 \mathrm{rpm}$ at $30{ }^{\circ} \mathrm{C}$. The following morning, $10 \mathrm{~mL}$ of overnight culture was added to $500 \mathrm{~mL}$ of YPD ( $0.2 \%$ glucose $)$ in a $2 \mathrm{~L}$ flask and cultured as above until the $\mathrm{OD}_{600}$ reached 0.8 . Then, $2 \%$ galactose (from a $20 \%$ stock) was added to the culture. After $22 \mathrm{~h}$, the cells were harvested via centrifugation at $4,000 \mathrm{~g}$ for $10 \mathrm{~min}$. The pellets were suspended in $400 \mathrm{~mL}$ of buffer containing 1X PBS, supplemented with $150 \mathrm{mM}$ $\mathrm{NaCl}, 10 \%$ glycerol, $2 \mathrm{mM} \beta$-mercaptoethanol and a protease inhibitor mix. Cell lysis was performed using a benchtop cell disruptor (Constant Systems) at increasing pressures $(25,28,30,32,35$ and 38 $\mathrm{kPsi})$. After lysis, the cell suspension was centrifuged at $10,000 \mathrm{~g}$ for $10 \mathrm{~min}$ at $4{ }^{\circ} \mathrm{C}$. The supernatant was retained and further ultracentrifuged at $150,000 \mathrm{~g}$ for $2 \mathrm{~h}$ to pellet the membranes. Isolated membranes of MPC1-8xHis or MPC2-10xHis were resuspended in similar solubilization buffer (SB) containing 1X PBS, $\mathrm{pH}$ 8.0, and $150 \mathrm{mM} \mathrm{NaCl} ; 0.5 \mathrm{mM}$ TCEP: $1 \%(\mathrm{w} / \mathrm{v})$ C12E8 was used for MPC2-10xHis, and $1 \%(\mathrm{w} / \mathrm{v})$ DDM was used for MPC1-8xHis. Membranedetergent mixtures at a 2:1 ratio were rotated for 1 $\mathrm{h}$ at $4{ }^{\circ} \mathrm{C}$. The suspension was cleared via ultracentrifugation at $100,000 \mathrm{~g}$ for $45 \mathrm{~min}$, and $10 \mathrm{mM}$ imidazole was added to the solubilized solution. The solubilized samples were incubated for $3 \mathrm{~h}$ at 4 - $\mathrm{C}$ with TALON beads (Clontech) preequilibrated with SB (supplemented with $0.1 \%$ (w/v) C12E8 + $0.1 \%$ (w/v) DDM for MPC2-GFP$10 x$ His and with $0.1 \%(\mathrm{w} / \mathrm{v})$ DDM for MPC1$8 \mathrm{xHis}$ ). Following incubation, the sample was loaded onto a glass column (Bio-Rad) and washed with 20 column volumes (CVs) of SB containing $0.1 \%(\mathrm{w} / \mathrm{v}) \mathrm{DDM}$ and $15 \mathrm{mM}$ imidazole. The column was subsequently washed with another 20 $\mathrm{CVs}$ of the same buffer containing $30 \mathrm{mM}$ imidazole. Bound proteins were eluted with SB containing $0.1 \%$ (w/v) DDM and $300 \mathrm{mM}$ imidazole. A similar procedure of column washing and elution was followed for both MPC2-10xHis and MPC1-8xHis. The eluted protein from the MPC1-8xHis construct was collected, concentrated to $5 \mathrm{mg} \cdot \mathrm{mL}^{-1}$ and immediately loaded onto a Superdex 200 PG 16/30 column (GE Healthcare, Sweden) pre-equilibrated in $20 \mathrm{mM}$ TRIS, $\mathrm{pH} 8.0$, $150 \mathrm{mM} \mathrm{NaCl}, 0.5 \mathrm{mM}$ TCEP and $0.03 \%$ DDM. The protein eluted from MPC2-10xHis construct was dialyzed overnight against $20 \mathrm{mM}$ TRIS, $\mathrm{pH}$ 8.0, $300 \mathrm{mM} \mathrm{NaCl}, 5 \%$ glycerol, $0.05 \mathrm{mM}$ TCEP and $0.03 \%$ DDM in a 6,000-Da MWCO dialysis bag (Spectrum Laboratories, USA) in the presence of 10:1 (GFP fused pyruvate carrier: protease) GST-tagged PreScission Protease at $4{ }^{\circ} \mathrm{C}$. After dialysis, the digest was passed through TALON (Clontech, USA) and GST (GE Healthcare, USA) beads equilibrated in dialysis buffer. The flowthrough containing the membrane protein was collected and concentrated to $5 \mathrm{mg} . \mathrm{mL}^{-1}$ and loaded directly onto a Superdex 200 PG 16/30 column previously equilibrated with $20 \mathrm{mM}$ TRIS, $\mathrm{pH} 8.0$, $300 \mathrm{mM} \mathrm{NaCl}, 5 \%$ glycerol, $0.05 \mathrm{mM}$ TCEP and $0.03 \%$ DDM. MPC2-10xHis in the absence of TCEP, and additional constructs, such as MPC2 
alone (plasmid construct devoid of the coding sequence for MPC1) and the MPC2.C54S mutant, were similarly purified as described above. For all MPC constructs used in the present study, a typical purification preparation starting with inducible expression from four liters of yeast culture, resulted in approximately $1 \mathrm{mg}$ of pure protein sample after full purification. Electrophoretic analysis was performed using Tricine-SDS-PAGE.

Confocal Microscopy. The Mito-mCherry plasmid for yeast expression used for mitochondrial labeling was kindly provided by Jean-Claude Martinou (Université de Genève, Switzerland). Yeast cotransformed with either of the MPC-expression plasmids or Mito-mCherry were cultured under the same conditions described above to facilitate the expression of GFP-labeled MPC. Subsequently, 10 $\mathrm{mL}$ of 22-h induced cells (at $\mathrm{OD}_{600}$ of 1) was centrifuged at $250 \mathrm{rpm}$ for $5 \mathrm{~min}$. The pellet was resuspended in $1 \mathrm{~mL}$ of YPD. From this, $7 \mu \mathrm{L}$ of cells were added to a slide and sealed with a cover slip. Samples were examined in the Biological Imaging Facility (LIB) at LNBio, using a Leica TCS SP8 confocal on a Leica DMI 6000 equipped with an HCX PL APO 63x/1.40 CS2 objective.

Quantitative PCR. Total RNA was extracted using the TRIzol reagent (Invitrogen Corporation), and 5 $\mu \mathrm{g}$ of total RNA was used for retrotranscription using GoScript ${ }^{\mathrm{TM}}$ Reverse Transcription System (Promega). Real-time quantitative PCR for MPC1 and $M P C 2$ was performed using the SYBR Green PCR Master Mix (Applied Biosystems). The threshold cycle (CT) values of the target genes were normalized to the actin gene, and relative expression ratios were calculated using the $2-\Delta \Delta \mathrm{CT}$ $\mathrm{Ct}$ method (36). Next, the readings were normalized to the URA3 transcripts to calculate the levels of transformed plasmids. The primer sequences were as follows: (1) Actin: ACT1.qPCR.For: 5' ATTCTGAGGTTGCTGCTTTGG - $3^{\prime}$ and ACT1.qPCR.Rev: $5^{\prime} \quad-$ TGTCTTGGTCTACCGACGATAG - 3'; (2) URA3: URA3.qPCR.For: $5^{\prime}{ }^{\prime}$; TGGCAGCAACAGGACTAGGATG - $3^{\prime}$ and URA3.qPCR.Rev: $5^{\prime}$ CGAACAGAAGGAAGAACGAAGGAAG - 3'; (3) Human MPC1: hMPC1.qPCR.For: 5' TGACCTTTGCTTTGTGTTGC - 3' and hMPC1.qPCR.Rev: $5^{\prime}$ CACCTTGGATCAATTGTGCT - 3'; (4) Human

$\begin{array}{lrrr}\text { MPC2: hMPC2.qPCR.For: } & 5^{\prime} & - \\ \text { CGATATGGCTAGACCAGCAG } & - & 3^{\prime} & \text { and } \\ \text { hMPC2.qPCR.Rev: } 5 & & { }^{\prime}- \\ \text { ACAGCGAACAAAGACCAATTT }-3^{\prime} \text {. } & \end{array}$

Fluorescence size-exclusion chromatography (FSEC). The appropriate detergent for protein extraction from membrane pellets was determined by FSEC analysis (35). A total of $250 \mu \mathrm{L}$ of solubilized membranes containing the overexpressed EGFP-fused pyruvate carrier in DDM (Anatrace, OH, USA) for MPC1 and C12E8 (Anatrace, OH, USA) for MPC2 was loaded onto a Superdex 200 PG 16/30 column. The column was pre-equilibrated with $20 \mathrm{mM}$ TRIS, $\mathrm{pH} 8.0,150$ $\mathrm{mM} \mathrm{NaCl}, 0.5 \mathrm{mM}$ TCEP and $0.03 \%$ DDM for MPC1-8xHis and $20 \mathrm{mM}$ TRIS, $\mathrm{pH} 8.0,300 \mathrm{mM}$ $\mathrm{NaCl}, 5 \%$ glycerol, $0.5 \mathrm{mM}$ TCEP and $0.03 \%$ DDM for MPC2- and connected to an AKTA start FPLC system at $4{ }^{\circ} \mathrm{C}$. The flow rate was set at 1 $\mathrm{mL} \cdot \mathrm{min}^{-1}$. Fractions of $200 \mu \mathrm{L}$ were drawn from the elution into 96-well optical plate. GFP emission was measured at $512 \mathrm{~nm}$ on bottom read, with an excitation wavelength of $488 \mathrm{~nm}$, using an EnSpire microplate reader (Perkin Elmer, Massachusetts, USA).

Calibration of gel filtration columns. Standard proteins from the low and high molecular weight Gel Filtration calibration kits (GE Healthcare, USA) were used. Protein resuspension buffer and running buffer were $20 \mathrm{mM}$ TRIS, $\mathrm{pH} 8.0,300 \mathrm{mM}$ $\mathrm{NaCl}, 5 \%$ Glycerol, $0.5 \mathrm{mM}$ TCEP and $0.03 \%$ DDM.

Mass spectrometry. The protein bands from gelfiltration-purified samples were extracted from tricine-SDS-PAGE gels. The gels were first stained with Coomassie dye for band identification and excision. Bands were then isolated and destained in methanol (50\%)/acetic acid (2.5\%) solution, and the samples were reduced, alkylated and digested with trypsin (37). Peptides $(4.5 \mu \mathrm{L})$ were separated by a C18 $(75 \mu \mathrm{m} \times 100 \mathrm{~mm}, 1.7 \mu \mathrm{m}$ particle size $)$ nanoUPLC (nanoAcquity, Waters) coupled with a Q-Tof Premier mass spectrometer (Waters) with a nanoelectrospray source at a flow rate of 0.6 $\mu \mathrm{L} . \mathrm{min}^{-1}$. The gradient was $2-35 \%$ acetonitrile in $0.1 \%$ formic acid over $31.6 \mathrm{~min}$ for the digested proteins. The nanoelectrospray voltage was set to $3.5 \mathrm{kV}$, with a cone voltage of $30 \mathrm{~V}$, and the source temperature was $80{ }^{\circ} \mathrm{C}$. The instrument was 
operated in the 'top three' mode, in which one MS spectrum is acquired, followed by MS/MS of the top three most-intense peaks detected. After MS/MS fragmentation, the ion was placed on an exclusion list for $60 \mathrm{~s}$. The spectra were acquired using MassLynx v.4.1 software, and the raw data files were converted to a peak list format (mgf) using Mascot Distiller v.2.4.0.0 software 2011 (Matrix Science Ltd.) and were searched against the Human UniProt-SwissProt database $(92,180$ sequences; 36,693,332 residues; release date March 2016) and the Yeast UniProt-SwissProt database (550,299 sequences; 196,347,838 residues; release date March 2016), with Saccharomyces cerevisiae taxonomy (7,743 sequences) using Mascot engine v.2.3.2 (Matrix Science Ltd.) with carbamidomethylation as a fixed modification, oxidation of methionine as a variable modification, one trypsin missed cleavage and a tolerance of 0.1 Da for both precursor and fragment ions.

Preparation of liposomes and proteoliposomes. The purified MPC protein samples were reconstituted into liposomes using previously described procedures $(38,39)$ with minor modifications. Briefly, asolectin from soybean extract (Sigma Aldrich) was dissolved in chloroform and dried into a thin film by blowing gaseous $\mathrm{N}_{2}$. This film was then resuspended to a final concentration of $4 \mathrm{mg} \cdot \mathrm{mL}^{-1}$ in buffer containing $20 \mathrm{mM}$ TRIS, $\mathrm{pH} 8.0,300 \mathrm{mM} \mathrm{NaCl}, 5$ $\%$ glycerol, $0.5 \mathrm{mM}$ TCEP and $0.03 \%$ (w/v) DDM and heated at $70{ }^{\circ} \mathrm{C}$ for $1 \mathrm{~h}$ with vortexing every 10 min. This suspension was sonicated in a water-bath sonicator at $40 \mathrm{kHz}$ for $1 \mathrm{~min}$ to obtain the homogenized lipid-detergent solution. The purified proteins were added to the solution at a lipid-toprotein ratio of 10:1 (w/w), along with $0.05 \%(\mathrm{w} / \mathrm{v})$ DDM to avoid protein denaturation. The ternary protein-lipid-detergent mixture was freeze-thawed three times for full reconstitution and then sonicated for 1 min under the aforementioned conditions. To remove the detergent and allow proteoliposome formation, Bio-Beads SM-2 resin (Bio-Rad) was added at a ratio of 1:0.2 (w/w) and incubated at 4 ${ }^{\circ} \mathrm{C}$ with exchange after 5, 10 and $40 \mathrm{~min}$, followed by ultra-centrifugation of the suspension at 100,000 $g$ for $45 \mathrm{~min}$, and the final proteoliposome pellet was resuspended in $20 \mathrm{mM}$ TRIS, $\mathrm{pH} 8.0,300 \mathrm{mM}$ $\mathrm{NaCl}, 5 \%$ glycerol, and $0.5 \mathrm{mM}$ TCEP. Proteinfree liposomes (small unilamellar vesicles, or
SUVs) were prepared following a similar procedure, except that the protein solution was replaced with the gel filtration buffer. Purified MPC2-10xHis in the absence of TCEP, as well as the purified proteins from the additional constructs, such as MPC2 alone (plasmid construct devoid of the coding sequence for MPC1) and the MPC2.C54S mutant, were reconstituted into liposomes following the above protocol. The size and homogeneity of the liposomes and proteoliposomes were assessed via dynamic light scattering and Nanoparticle Tracking Analysis (NTA, Supp. Fig. 2A) as described below. To check for unwanted bursting or swelling of the liposomes and proteoliposomes upon incubation with the pyruvate solution, dynamic light scattering analysis was performed (Supp. Fig. 2B).

Nanoparticle Tracking Analysis. The size, homogeneity and concentration of the liposomes and proteoliposomes were assessed via NTA, as available on the NanoSight instrument (Malvern) Dynamic light scattering measurements were performed on a NanoSight NS300 (Malvern Instruments Ltd., United Kingdom). Fifty microliters of total proteoliposomes was diluted in $1 \mathrm{~mL}$ of filtered buffer (20 mM TRIS, pH 8.0, 300 $\mathrm{mM} \mathrm{NaCl}, 5 \%$ glycerol, $0.5 \mathrm{mM}$ TCEP); $500 \mu \mathrm{L}$ of this suspension was injected into the sample chamber using a sterile syringe. All measurements were performed at $18{ }^{\circ} \mathrm{C}$, and the average of quintuple readings was determined.

In vitro pyruvate transport. Transport analysis was performed at room temperature and initiated by mixing $50 \mu \mathrm{L}$ of the liposome/proteoliposome samples with $100 \mu \mathrm{L}$ of $50 \mu \mathrm{M}$ sodium pyruvate in a 96-well flat bottom Greiner plate. To induce a $\mathrm{pH}$ gradient of 1.5 units between the inner and outer vesicle environments, sodium pyruvate (Sigma, USA) was resuspended at the desired concentration in transport buffer containing $120 \mathrm{mM} \mathrm{KCl}$ and 100 $\mathrm{mM}$ MES, $\mathrm{pH}$ 6.5. Upon incubation for the desired times $(1,3,5,15$ and $30 \mathrm{~min})$ at room temperature, $50 \mu \mathrm{L}$ of stop buffer ( $2 \mathrm{nM}$ LDHA, $0.5 \mathrm{mM} \mathrm{NADH}$, $50 \mathrm{mM}$ TRIS, $\mathrm{pH}$ 8.0) was added. The mixture was immediately subjected to quantification of absorbance at $340 \mathrm{~nm}$ on an EnSpire plate reader (Perkin Elmer, USA) to track the oxidation of NADH. In addition, the necessity of various proton electrochemical gradients was measured as described above with minor modifications. Briefly, 
sodium pyruvate was also dissolved in transport buffers containing $120 \mathrm{mM} \mathrm{KCl}, 100 \mathrm{mM}$ HEPES, $\mathrm{pH} 7.2$ (to achieve $\Delta \mathrm{pH}$ of 0.8 ) and $120 \mathrm{mM} \mathrm{KCl}$, $100 \mathrm{mM}$ TRIS, $\mathrm{pH} 8.0$ (for $\Delta \mathrm{pH}=0$ ). Raw absorption readings were converted to amounts of NADH using an extinction coefficient of 6,220 $\mathrm{M}^{-1} \cdot \mathrm{cm}^{-1}$. Initial velocities for LDHA under all conditions were obtained using linear regression, keeping unrestrained intercepts. When appropriate, analysis of covariance (ANCOVA) was performed to determine whether the difference between two similar slopes was statistically non-significant (indicated as n.s. in the figures and respective legends). Velocities were rounded up to the first significant digit. The obtained enzyme velocities for each transport condition were compared with an LDHA standard curve (Supp. Fig. 2C) generated under the same chemical conditions used in the assay but in the absence of liposomes or proteoliposomes, termed Ctrl (-L/PL). Spontaneous oxidation of NADH was shown not to occur during the experimental timeframe (Supp. Fig. 2E). The plasmid for bacterial expression of human LDHA was a kind gift from Anne Le (Johns Hopkins Medicine, USA). The experiments were repeated four to six times, and the means \pm standard deviations obtained were graphically represented.

Inhibition of MPC2-dependent in vitro pyruvate transport. Experiments to demonstrate the MPC2 pyruvate transport inhibition were performed at room temperature. Fifty microliters of liposome/proteoliposome samples was preincubated for $30 \mathrm{~min}$ with UK5099 and rosiglitazone dissolved in $0.1 \% \mathrm{DMSO}$ at a final concentration of $50 \mu \mathrm{M}$. As a control, liposome/proteoliposome samples were also similarly incubated with $0.1 \%$ DMSO. After incubation for $30 \mathrm{~min}, 100 \mu \mathrm{L}$ of $50 \mu \mathrm{M}$ sodium pyruvate was added to the inhibitor-treated liposome/proteoliposome samples in a 96-well flatbottom Greiner plate. Upon incubation for an additional $30 \mathrm{~min}$ at room temperature, $50 \mu \mathrm{L}$ of stop buffer ( $2 \mathrm{nM}$ LDHA, $0.5 \mathrm{mM}$ NADH, $50 \mathrm{mM}$ TRIS, pH 8.0) was added. The mixture was immediately subjected to quantification of absorbance at $340 \mathrm{~nm}$ on an EnSpire plate reader (Perkin Elmer, USA) to track the oxidation of NADH. The obtained enzyme velocities for transport in the presence of inhibitor were compared with an LDHA standard curve (Supp.
Fig. 2C) generated under the same conditions used in the assay, but in the absence of liposomes or proteoliposomes, termed Ctrl (-L/PL). Data processing and analysis were performed as described above. The experiments were repeated four to six times, and the means \pm standard deviations obtained were graphically represented.

Substrate specificity assay. Lactate was assessed using the L-lactate colorimetric assay kit from Abcam, Inc. (ab65331) according to the manufacturer's instructions, with minor modifications. Substrate specificity analysis was performed at room temperature and initiated by mixing $50 \mu \mathrm{L}$ of the liposome/proteoliposome samples with $100 \mu \mathrm{L}$ of $50 \mu \mathrm{M}$ sodium lactate (Sigma, USA) in a 96-well flat-bottom Greiner plate. Sodium lactate (Sigma, USA) was suspended to the desired final concentrations of 30,60 and 120 $\mu \mathrm{M}$ in transport buffer containing $120 \mathrm{mM} \mathrm{KCl}$, $100 \mathrm{mM}$ MES, $\mathrm{pH}$ 6.5, which was also used to dissolve sodium pyruvate. Upon incubation for 30 min at room temperature, $50 \mu \mathrm{L}$ of the lactate enzyme mix provided with the kit was added, and the plate was measured at $450 \mathrm{~nm}$. Data processing and analysis were performed as described above for pyruvate transport. The obtained enzyme velocities for each transport condition were compared with a lactate standard curve obtained in a vesicle-free solution, termed Ctrl (-L/PL). The experiments were repeated four to six times, and the means \pm standard deviations obtained were graphically represented.

Chemical cross-linking of MPC2. Cross-linking of MPC2 in mitochondrial extracts was performed according as previously published (6), but using DSS instead. For crosslinking of purified protein and protein reconstituted in proteoliposomes, MPC2 was prepared as described above, except that HEPES was used instead of TRIS in the final gel filtration buffer (20 mM HEPES, pH 8.0, $300 \mathrm{mM}$ $\mathrm{NaCl}, 5 \%$ glycerol, $0.05 \mathrm{mM}$ TCEP and $0.03 \%$ DDM). Approximately $10 \mu \mathrm{g}$ of protein was used in each reaction and incubated with DSS at 0.2, 0.4, 2 and $4 \mathrm{mM}$ for $30 \mathrm{~min}$ at room temperature. The reactions were stopped using $50 \mathrm{mM}$ TRIS, $\mathrm{pH}$ 8.0.

Growth assays. Yeast cells were grown overnight and inoculated in $5 \mathrm{~mL}$ of SD-URA medium supplemented with $0.2 \%$ glucose for $22 \mathrm{~h}$ at $30^{\circ} \mathrm{C}$, $200 \mathrm{rpm}$. Cells were recovered by centrifugation for 
$5 \mathrm{~min}$ at $3000 \mathrm{~g}, 4{ }^{\circ} \mathrm{C}$, washed twice and then resuspended in $2.5 \mathrm{~mL}$ of SD-URA-VAL supplemented with $0.2 \%$ glucose. $\mathrm{OD}_{600}$ was adjusted to 0.034 (approximately 0.23 at $10 \mathrm{~mm}$ path-length) for all conditions using an EnSpire Plate Reader (Perkin-Elmer). Then, $10 \mu \mathrm{L}$ of each cell culture was added to a 96-well plate containing $200 \mu \mathrm{L}$ of SD-URA (supplemented with $0.2 \%$ glucose) in the presence and absence of valine. Optical density was measured every $5 \mathrm{~min}$, while cells were left to grow inside the EnSpire Plate Reader, with shaking at $200 \mathrm{rpm}$, at $30^{\circ} \mathrm{C}$.

Yeast cells were grown overnight and inoculated in $10 \mathrm{~mL}$ of SD-URA medium supplemented with 0.2 $\%$ glucose for $22 \mathrm{~h}$ at $30{ }^{\circ} \mathrm{C}, 200 \mathrm{rpm}$. Cells were recovered by centrifugation for $5 \mathrm{~min}$ at $3000 \mathrm{~g}, 4$ ${ }^{\circ} \mathrm{C}$, and resuspended in $1 \mathrm{~mL}$ of SD-URA-VAL. $\mathrm{OD}_{600}$ was adjusted to 0.3 for all conditions using an EnSpire Plate Reader (Perkin-Elmer), and cells were centrifuged and resuspended again in the same culture medium.

Oxygen consumption measurements. Yeast cells were grown overnight and inoculated on $10 \mathrm{~mL}$ of SD-URA medium supplemented with $0.2 \%$ glucose for $22 \mathrm{~h}$ at $30{ }^{\circ} \mathrm{C}, 200 \mathrm{rpm}$. Cells were recovered via centrifugation for $5 \mathrm{~min}, 3.000 \mathrm{~g}$ at 4 ${ }^{\circ} \mathrm{C}$ and resuspended in $1 \mathrm{~mL}$ of $25 \mathrm{mM}$ HEPESBuffered DMEM, pH 7.1 (Sigma, D5030). OD 600 was adjusted to 0.034 (approximately 0.23 at 10$\mathrm{mm}$ path-length) for all conditions using an EnSpire
Plate Reader (Perkin-Elmer), and cells were centrifuged and resuspended again in the same buffer to remove any residual glucose. Measurements were performed using an Oxytherm (Hansatech, Norfolk, UK). Briefly, $970 \mu \mathrm{L}$ of buffered DMEM was pre-warmed to $30^{\circ} \mathrm{C}$ with shaking at $100 \mathrm{rpm}$ in a reaction chamber. Next, 30 $\mu \mathrm{L}$ of OD-standardized cells was added, and the chamber was equilibrated open for $1 \mathrm{~min}$. The chamber was then closed and incubated for $8 \mathrm{~min}$ to measure the basal respiration, followed by another $8 \mathrm{~min}$ for glucose $(0.08 \%$ final concentration to induce mitochondrial oxidation of pyruvate and not fermentation to ethanol (40)), and the final 8 min for ethanol ( $2 \%$ final concentration to inhibit any residual fermentation $(41,42))$. The raw oxygen concentration in the chamber collected every second was used to calculate multiple linear regressions of $150 \mathrm{~s}$ in length and average the oxygen consumption rate using the $\mathrm{R}$ software package.

Circular Dichroism. Synchrotron Radiation Circular Dichroism experiments were performed using a nitrogen-flushed Module X end-station spectrophotometer at B23 Beamline at the Diamond Light Source, Oxfordshire, UK (43), under proposal SM16289-2.

\section{ACKNOWLEDGEMENTS}

This work was supported by FAPESP under grants 2014/20673-2 (to ALBA) and 2015/25832-4 (to SMGD), fellowships 2014/06954-9 and 2017/02391-8 (to RSKN), 2014/12663-7 (to ZI), and scholarships 2015/02734-7 (to JENQ) and 2014/17820-3 (to DA). We thank LNBio for accessibility to core facilities as well as for financial support. We are very grateful to Dr. Alessandra Girasole for expert technical support and to Prof. Eneida de Paula (Unicamp, Brazil) for help in devising the in vitro pyruvate transport assay. The authors are also grateful for the use of the Membrane Protein Laboratory funded by the Wellcome Trust (099165/Z/12/Z and 202892/Z/16/Z) at the Diamond Light Source, UK. We acknowledge the support by the staff of the B23 Synchrotron Radiation Circular Dichroism beamline at the Diamond Light Source, UK.

\section{COMPETING INTERESTS}

The authors declare no competing financial interests.

\section{AUTHOR CONTRIBUTIONS}


S.M.G.D. and A.L.B.A. conceived and initiated the research; R.S.K.N, J.E.N.Q, D.A., Z.I., J.B., H.G.S., C.F.R.A., A.M.F., B.A.P., S.R.C., J.F.O., A.C.T.S. and A.L.B.A. conducted the research; R.S.K.N, J.E.N.Q, D.A., Z.I., J.B., H.G.S., C.F.R.A., A.M.F., B.A.P., S.R.C., K.G.F., A.F.P.L., P.C., I.M., S.M.G.D and A.L.B.A. discussed and analyzed the data; R.S.K.N, J.E.N.Q, D.A, Z.I., S.M.G.D and A.L.B.A. wrote the manuscript. All authors revised and approved the final manuscript.

\section{REFERENCES}

1. Halestrap, A. P., and Denton, R. M. (1974) Specific inhibition of pyruvate transport in rat liver mitochondria and human erythrocytes by alpha-cyano-4-hydroxycinnamate. Biochem. J. 138, 313316

2. Bricker, D. K., Taylor, E. B., Schell, J. C., Orsak, T., Boutron, A., Chen, Y.-C., Cox, J. E., Cardon, C. M., Van Vranken, J. G., Dephoure, N., Redin, C., Boudina, S., Gygi, S. P., Brivet, M., Thummel, C. S., and Rutter, J. (2012) A mitochondrial pyruvate carrier required for pyruvate uptake in yeast, Drosophila, and humans. Science. 337, 96-100

3. Herzig, S., Raemy, E., Montessuit, S., Veuthey, J.-L., Zamboni, N., Westermann, B., Kunji, E. R. S., and Martinou, J.-C. (2012) Identification and functional expression of the mitochondrial pyruvate carrier. Science. 337, 93-96

4. Schell, J. C., Olson, K. A., Jiang, L., Hawkins, A. J., Van Vranken, J. G., Xie, J., Egnatchik, R. A., Earl, E. G., DeBerardinis, R. J., and Rutter, J. (2014) A Role for the Mitochondrial Pyruvate Carrier as a Repressor of the Warburg Effect and Colon Cancer Cell Growth. Mol. Cell. 56, 400413

5. Vacanti, N. M., Divakaruni, A. S., Green, C. R., Parker, S. J., Henry, R. R., Ciaraldi, T. P., Murphy, A. N., and Metallo, C. M. (2014) Regulation of Substrate Utilization by the Mitochondrial Pyruvate Carrier. Mol. Cell. 56, 425-435

6. Bender, T., Pena, G., and Martinou, J. J.-C. (2015) Regulation of mitochondrial pyruvate uptake by alternative pyruvate carrier complexes. EMBO J. 34, 1-14

7. Liang, L., Li, Q., Huang, L., Li, D., and Li, X. (2015) Sirt3 binds to and deacetylates mitochondrial pyruvate carrier 1 to enhance its activity. Biochem. Biophys. Res. Commun. 468, $807-812$

8. Kortüm, G., Vogel, W., and Andrussow, K. (1960) Dissociation constants of organic acids in aqueous solution. Pure Appl. Chem. 1, 187-536

9. Compan, V., Pierredon, S., Vanderperre, B., Krznar, P., Marchiq, I., Zamboni, N., Pouyssegur, J., and Martinou, J. C. (2015) Monitoring Mitochondrial Pyruvate Carrier Activity in Real Time Using a BRET-Based Biosensor: Investigation of the Warburg Effect. Mol. Cell. 59, 491-501

10. Vanderperre, B., Bender, T., Kunji, E. R. S., and Martinou, J. C. (2015) Mitochondrial pyruvate import and its effects on homeostasis. Curr. Opin. Cell Biol. 33, 35-41

11. Halestrap, A. P. (2012) The mitochondrial pyruvate carrier: Has it been unearthed at last? Cell Metab. 16, 141-143

12. McCommis, K. S., and Finck, B. N. (2015) Mitochondrial pyruvate transport: a historical perspective and future research directions. Biochem. J. 466, 443-454

13. Gray, L. R., Rauckhorst, A. J., and Taylor, E. B. (2016) A Method for Multiplexed Measurement of Mitochondrial Pyruvate Carrier Activity. J. Biol. Chem. 291, jbc.M115.711663 
14. Halestrap, A. P. (1975) The mitochondrial pyruvate carrier. Kinetics and specificity for substrates and inhibitors. Biochem. J. 148, 85-96

15. Halestrap, A. P. (1978) Pyruvate and Ketone-Body Transport across the Mitochondrial Membrane. Biochem. J. 172, 377-387

16. Colca, J. R., McDonald, W. G., Cavey, G. S., Cole, S. L., Holewa, D. D., Brightwell-Conrad, A. S., Wolfe, C. L., Wheeler, J. S., Coulter, K. R., Kilkuskie, P. M., Gracheva, E., Korshunova, Y., Trusgnich, M., Karr, R., Wiley, S. E., Divakaruni, A. S., Murphy, A. N., Vigueira, P. A., Finck, B. N., and Kletzien, R. F. (2013) Identification of a Mitochondrial Target of Thiazolidinedione Insulin Sensitizers (mTOT)-Relationship to Newly Identified Mitochondrial Pyruvate Carrier Proteins. PLoS One. 8, 1-10

17. Divakaruni, A. S., Wallace, M., Buren, C., Martyniuk, K., Andreyev, A. Y., Li, E., Fields, J. A., Cordes, T., Reynolds, I. J., Bloodgood, B. L., Raymond, L. A., Metallo, C. M., and Murphy, A. N. (2017) Inhibition of the mitochondrial pyruvate carrier protects from excitotoxic neuronal death. $J$. Cell Biol. 216, 1091-1105

18. Divakaruni, A. S., Wiley, S. E., Rogers, G. W., Andreyev, A. Y., Petrosyan, S., Loviscach, M., Wall, E. a, Yadava, N., Heuck, A. P., Ferrick, D. a, Henry, R. R., McDonald, W. G., Colca, J. R., Simon, M. I., Ciaraldi, T. P., and Murphy, A. N. (2013) Thiazolidinediones are acute, specific inhibitors of the mitochondrial pyruvate carrier. Proc. Natl. Acad. Sci. U. S. A. 110, 5422-7

19. Patterson, J. N., Cousteils, K., Lou, J. W., Fox, J. E. M., MacDonald, P. E., and Joseph, J. W. (2014) Mitochondrial metabolism of pyruvate is essential for regulating glucose-stimulated insulin secretion. J. Biol. Chem. 289, 13335-13346

20. Rampelt, H., and Laan, M. Van Der (2015) Metabolic remodeling : a pyruvate transport affair. EMBO J. 34, 835-7

21. Newstead, S., Kim, H., von Heijne, G., Iwata, S., and Drew, D. (2007) High-throughput fluorescent-based optimization of eukaryotic membrane protein overexpression and purification in Saccharomyces cerevisiae. Proc. Natl. Acad. Sci. U. S. A. 104, 13936-13941

22. Nałecz, M. J., Nałecz, K. a, Broger, C., Bolli, R., Wojtczak, L., and Azzi, a (1986) Extraction, partial purification and functional reconstitution of two mitochondrial carriers transporting keto acids: 2-oxoglutarate and pyruvate. FEBS Lett. 196, 331-336

23. Hildyard, J. C. W., Ämmälä, C., Dukes, I. D., Thomson, S. A., and Halestrap, A. P. (2005) Identification and characterisation of a new class of highly specific and potent inhibitors of the mitochondrial pyruvate carrier. Biochim. Biophys. Acta - Bioenerg. 1707, 221-230

24. Halestrap, A. P. (1976) The mechanism of the inhibition of the mitochondrial pyruvate transportater by alpha-cyanocinnamate derivatives. Biochem. J. 156, 181-3

25. Diekert, K., de Kroon, a I., Kispal, G., and Lill, R. (2001) Isolation and subfractionation of mitochondria from the yeast Saccharomyces cerevisiae. Methods Cell Biol. 65, 37-51

26. Seddon, A. M., Curnow, P., and Booth, P. J. (2004) Membrane proteins, lipids and detergents: not just a soap opera. Biochim. Biophys. Acta. 1666, 105-17

27. Floyd, B. J., Wilkerson, E. M., Veling, M. T., Minogue, C. E., Xia, C., Beebe, E. T., Wrobel, R. L., Cho, H., Kremer, L. S., Alston, C. L., Gromek, K. A., Dolan, B. K., Ulbrich, A., Stefely, J. A., Bohl, S. L., Werner, K. M., Jochem, A., Westphall, M. S., Rensvold, J. W., Taylor, R. W., Prokisch, H., Kim, J. J. P., Coon, J. J., and Pagliarini, D. J. (2016) Mitochondrial Protein Interaction Mapping Identifies Regulators of Respiratory Chain Function. Mol. Cell. 63, 621-632

28. Huttlin, E. L., Ting, L., Bruckner, R. J., Gebreab, F., Gygi, M. P., Szpyt, J., Tam, S., Zarraga, G., 
Colby, G., Baltier, K., Dong, R., Guarani, V., Vaites, L. P., Ordureau, A., Rad, R., Erickson, B. K., Wühr, M., Chick, J., Zhai, B., Kolippakkam, D., Mintseris, J., Obar, R. A., Harris, T., ArtavanisTsakonas, S., Sowa, M. E., De Camilli, P., Paulo, J. A., Harper, J. W., and Gygi, S. P. (2015) The BioPlex Network: A Systematic Exploration of the Human Interactome. Cell. 162, 425-440

29. Timoń-Gómez, A., Proft, M., and Pascual-Ahuir, A. (2013) Differential regulation of mitochondrial pyruvate carrier genes modulates respiratory capacity and stress tolerance in yeast. PLoS One. 8, 1-9

30. Vadvalkar, S. S., Matsuzaki, S., Eyster, C. A., Giorgione, J. R., Bockus, L. B., Kinter, C. S., Kinter, M., and Humphries, K. M. (2017) Decreased Mitochondrial Pyruvate Transport Activity in the Diabetic Heart: Role of Mitochondrial Pyruvate Carrier 2 (MPC2) Acetylation. J. Biol. Chem. 292, 4423-4433

31. Lundby, A., Lage, K., Weinert, B. T., Bekker-Jensen, D. B., Secher, A., Skovgaard, T., Kelstrup, C. D., Dmytriyev, A., Choudhary, C., Lundby, C., and Olsen, J. V. (2012) Proteomic Analysis of Lysine Acetylation Sites in Rat Tissues Reveals Organ Specificity and Subcellular Patterns. Cell Rep. 2, 419-431

32. Hornbeck, P. V., Zhang, B., Murray, B., Kornhauser, J. M., Latham, V., and Skrzypek, E. (2015) PhosphoSitePlus, 2014: mutations, PTMs and recalibrations. Nucleic Acids Res. 43, D512-D520

33. Vigueira, P. A., McCommis, K. S., Schweitzer, G. G., Remedi, M. S., Chambers, K. T., Fu, X., McDonald, W. G., Cole, S. L., Colca, J. R., Kletzien, R. F., Burgess, S. C., and Finck, B. N. (2014) Mitochondrial Pyruvate Carrier 2 Hypomorphism in Mice Leads to Defects in GlucoseStimulated Insulin Secretion. Cell Rep. 7, 2042-2053

34. Miller, C. A., Martinat, M. A., and Hyman, L. E. (1998) Assessment of aryl hydrocarbon receptor complex interactions using pBEVY plasmids: expressionvectors with bi-directional promoters for use in Saccharomyces cerevisiae. Nucleic Acids Res. 26, 3577-83

35. Drew, D., Newstead, S., Sonoda, Y., Kim, H., von Heijne, G., and Iwata, S. (2008) GFP-based optimization scheme for the overexpression and purification of eukaryotic membrane proteins in Saccharomyces cerevisiae. Nat. Protoc. 3, 784-798

36. Livak, K. J., and Schmittgen, T. D. (2001) Analysis of relative gene expression data using realtime quantitative PCR and. Methods. 25, 402-408

37. Shevchenko, A., Wilm, M., Vorm, O., and Mann, M. (1996) Mass spectrometric sequencing of proteins silver-stained polyacrylamide gels. Anal. Chem. 68, 850-8

38. Xu, Y., Tao, Y., Cheung, L. S., Fan, C., Chen, L.-Q., Xu, S., Perry, K., Frommer, W. B., and Feng, L. (2014) Structures of bacterial homologues of SWEET transporters in two distinct conformations. Nature. 515, 448-452

39. Yoneda, J. S., Rigos, C. F., De Lourenço, T. F. A., Sebinelli, H. G., and Ciancaglini, P. (2014) $\mathrm{Na}, \mathrm{K}-\mathrm{ATP}$ ase reconstituted in ternary liposome: The presence of cholesterol affects protein activity and thermal stability. Arch. Biochem. Biophys. 564, 136-141

40. Takeda, K., Starzynski, C., Mori, A., and Yanagida, M. (2015) The critical glucose concentration for respiration-independent proliferation of fission yeast, Schizosaccharomyces pombe.

Mitochondrion. 22, 91-95

41. Fernandes, L., Côrte-Real, M., Loureiro, V., Loureiro-Dias, M. C., and Leão, C. (1997) Glucose respiration and fermentation in Zygosaccharomyces bailii and Saccharomyces cerevisiae express different sensitivity patterns to ethanol and acetic acid. Lett. Appl. Microbiol. 25, 249-253

42. Brown, S. W., Oliver, S. G., Harrison, D. E. F., and Righelato, R. C. (1981) Ethanol inhibition of 
yeast growth and fermentation: Differences in the magnitude and complexity of the effect. Eur. $J$. Appl. Microbiol. Biotechnol. 11, 151-155

43. Hussain, R., Jávorfi, T., and Siligardi, G. (2012) Circular dichroism beamline B23 at the Diamond Light Source. J. Synchrotron Radiat. 19, 132-5 


\section{FIGURE LEGENDS}

Fig. 1. Recombinant expression and purification of human MPC. (A) A schematic of the initial human MPC protein constructs expressed in yeast (co-expression set 1). Left panel: Proper localization to the mitochondria was confirmed via confocal microscopy. DIC: Differential interference contrast. Middle panel: Electrophoretic analysis of MPC1-8xHis samples purified using Co-IMAC and GF. *N-terminally truncated portion of 60S RPL28. The inset displays the silver staining and in-gel fluorescence detection of trace amounts of MPC2-GFP, which co-purified with MPC1. Right panel: The corresponding GF trace showed a predominant protein-detergent monodisperse peak at approximately $64 \mathrm{kDa}$. (B) Diagram of the alternative MPC constructs (co-expression set 2) and corresponding confocal microscopy (left panel). Middle panel: Electrophoretic (Tricine-SDS-PAGE) analysis of representative chromatography steps. PP: PreScission Protease. Right panel: GF peak analysis revealed that pure monodisperse MPC2 (associated with DDM) was obtained at an equivalent molecular weight of $70 \mathrm{kDa}$. (C) Diagram of the single expressed MPC2 construct and corresponding confocal microscopy (left panel). Middle panel: Electrophoretic (Tricine-SDS-PAGE) analysis of representative chromatography steps. PP: PreScission Protease. Right panel: GF peak analysis revealed that pure monodisperse MPC2 (associated with DDM) was obtained at an equivalent molecular weight of $70 \mathrm{kDa}$. In all GF profiles above, $\mathrm{v}_{\mathrm{o}}$ indicates void volume, and $\mathrm{v}_{\mathrm{t}}$ indicates the total liquid volume of the GF column. The corresponding elution volumes for calibration standards are shown in red.

Fig. 2. In vitro MPC activity and its dependence on time and electrochemical gradient. (A) Quantification of extraliposomal pyruvate, as detected based on LDHA activity, in liposomes (L) and proteoliposomes (PL) reconstituted with MPC1 and MPC2 and a control condition free of lipid vesicles (Ctrl (-L/PL)). The inset indicates the $\mathrm{pH}$ gradient across the outer and inner vesicle environments. Left panel: Initial velocities of LDHA for which the differences are not statistically significant (n.s.; ANCOVA $P>0.01 ;$ ) are indicated. An asterisk $(*)$ indicates that MPC1 co-purified with yeast RPL28. MPC2 expressed and purified in the complete absence of MPC1 is indicated with two asterisks $\left({ }^{* *}\right)$. Right panel: Using the experimental Michaelian parameters for LDHA (Supp. Fig. 2C), the corresponding external pyruvate concentrations were calculated and plotted for each condition. The extent of transport for a given proteoliposome sample was quantified based on the loss of pyruvate from the extraliposomal medium with respect to the protein-free liposome and expressed as percentages. (B) Quantification of external pyruvate in the liposome and MPC2-proteoliposome as a function of different incubation times with a $\triangle \mathrm{pH}$ of 1.5 units. An exponential decay model curve was fitted (solid blue line, $\mathrm{R}^{2}=0.96$ ). (C) First to third panels depict the quantification of external pyruvate after $30 \mathrm{~min}$ of incubation for $\Delta \mathrm{pH}=1.5,0.8$ and 0 . Right panel: Using the appropriate experimental Michaelian parameters for LDHA for each external $\mathrm{pH}$ applied (Supp. Fig. 2C), the corresponding external pyruvate concentrations were calculated and plotted for each condition to demonstrate the dependence of pyruvate transport on the electrochemical gradient according to the respective insets. In all bar graphs above, the protein components of proteoliposomes are indicated inside the respective bars.

Fig. 3. Evaluation of the effect of small-molecule inhibition, redox balance and substrate type on MPC2-dependent transport. (A) Left panel: Quantification of extraliposomal pyruvate in liposomes and MPC2-proteoliposmes in the presence of DMSO (vehicle control) and the well-established MPC inhibitors UK-5099 and rosiglitazone (Rgz). The inset indicates the $\mathrm{pH}$ gradient across the outer and inner vesicle environments. Statistically comparable initial velocities are indicated (n.s.; ANCOVA $P>0.01$ ). Right panel: The corresponding extraliposomal substrate levels were calculated based on corresponding LDHA activity. The extent of transport for a given proteoliposome sample was quantified based on the loss of pyruvate from the extraliposomal medium with respect to the protein-free liposome and expressed as percentages. (B) Left panel: Quantification of extraliposomal pyruvate in proteoliposomes reconstituted with wild-type MPC2 in the presence and absence of TCEP as well as supplemented TCEP. The inset indicates the $\mathrm{pH}$ gradient across the outer and inner vesicle environments. The comparison between the blue and black curves indicates that LDHA activity was not affected by the absence of TCEP. Right panel: 
Quantification of external pyruvate and corresponding transport levels (as percentages). (C) Similar analyses performed for the point mutant MPC2.C54S. (D) Under the same chemical conditions used for pyruvate transport, MPC2 displays selectivity for this substrate, as no apparent transport of lactate was observed over a range of extraliposomal concentrations $(30,60$ and $120 \mu \mathrm{M})$. As such, the enzymatic quantification of lactate at the beginning of the reaction and after a 30-min incubation (at equilibrium) are statistically indistinguishable (n.s.) between liposomes (L, gray) and proteoliposomes (PL, light gray) compared with a liposome/proteoliposome-free control (black, Ctrl (-L/PL)).

Figure 4. Autonomous transport function of MPC2 in vivo. (A) Differential growth rates of $3 \Delta$ cells or JRY472 (green circles) expressing either wild-type MPC2 (blues squares) or MPC2.C54S in the absence and presence of external valine. (B) Differential respiration rates of $3 \Delta$ cells or JRY472 (green circles) expressing either wild-type MPC2 (blues squares) or MPC2.C54S when exposed to glucose (filled geometric shapes) and ethanol (empty geometric shapes). Lines indicate the mean \pm standard error. The inset displays the statistical significance of the differences according to the Benjamini-Hochberg multiple testing correction.

Fig. 5. Oligomeric state and secondary structure composition of MPC2. (A) Chemical cross-linking suggested that MPC2 assembled into higher oligomers in a lipid environment. Left panel: Cross-linking of human MPC2 from isolated yeast mitochondrial extracts by $0.2 \mathrm{mM}$ DSS. Middle panel: Cross-linking, using increasing DSS concentrations $(0.2-4 \mathrm{mM})$, of purified MPC2-detergent (DDM) complex. Right panel: Cross-linking, using increasing DSS concentrations $(0.2-4 \mathrm{mM})$, of purified MPC2 reconstituted in asolectin-derived lipid vesicles. (B) Secondary structure analysis of MPC2 in presence and absence of ligands, as probed by Circular Dichroism. Far-UV CD spectra, as well as calculated percentage of secondary structure content in the form of pie-chart, for MPC2 alone (Ctrl; top left), in the presence of 25 $\mu \mathrm{M}$ pyruvate (+Pyr; top right), in the absence of TCEP (-TCEP; bottom left), and in the presence of $50 \mu \mathrm{M}$ rosiglitazone ( $+\mathrm{Rgz}$; bottom right). 
FIGURE 1.

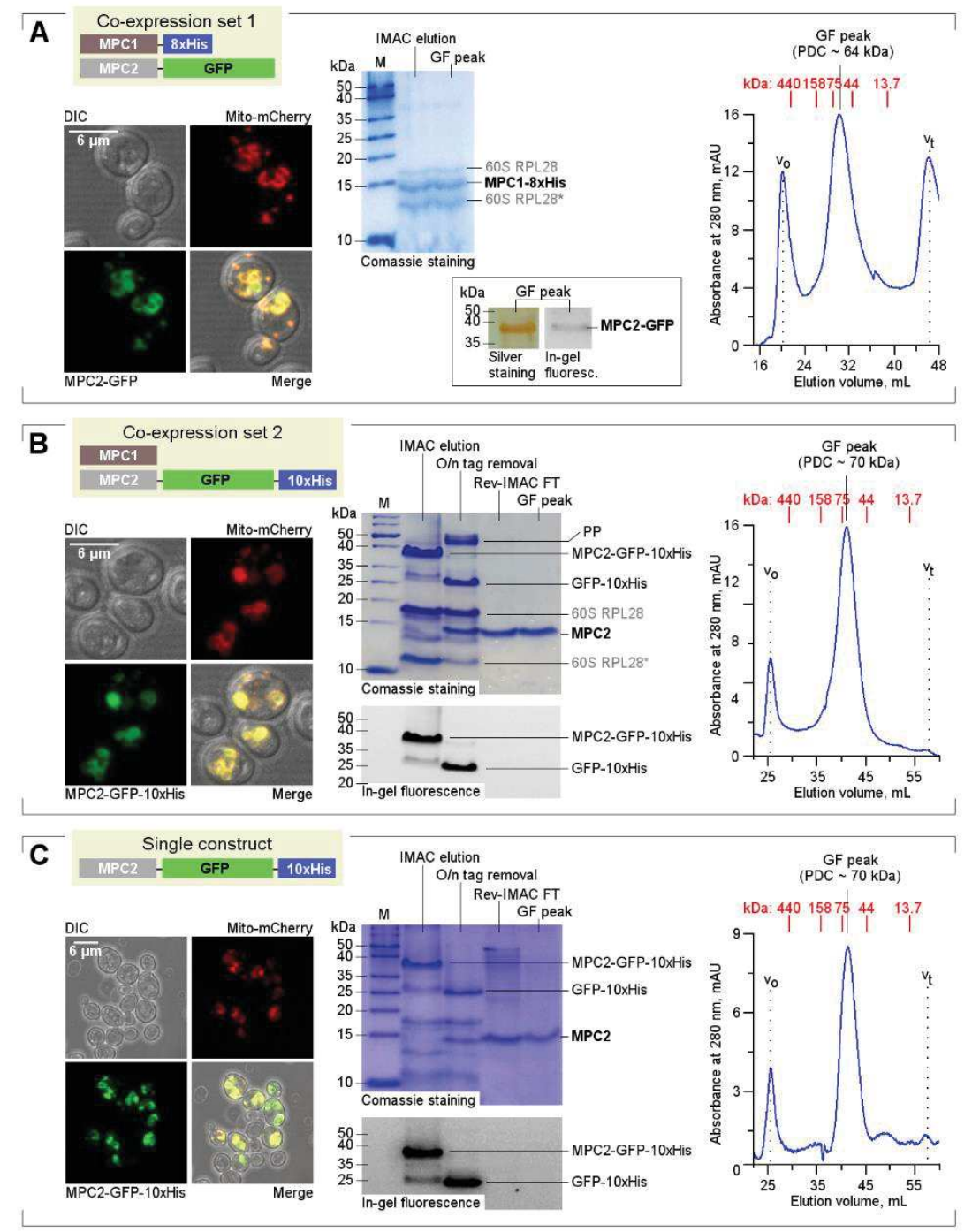


FIGURE 2.
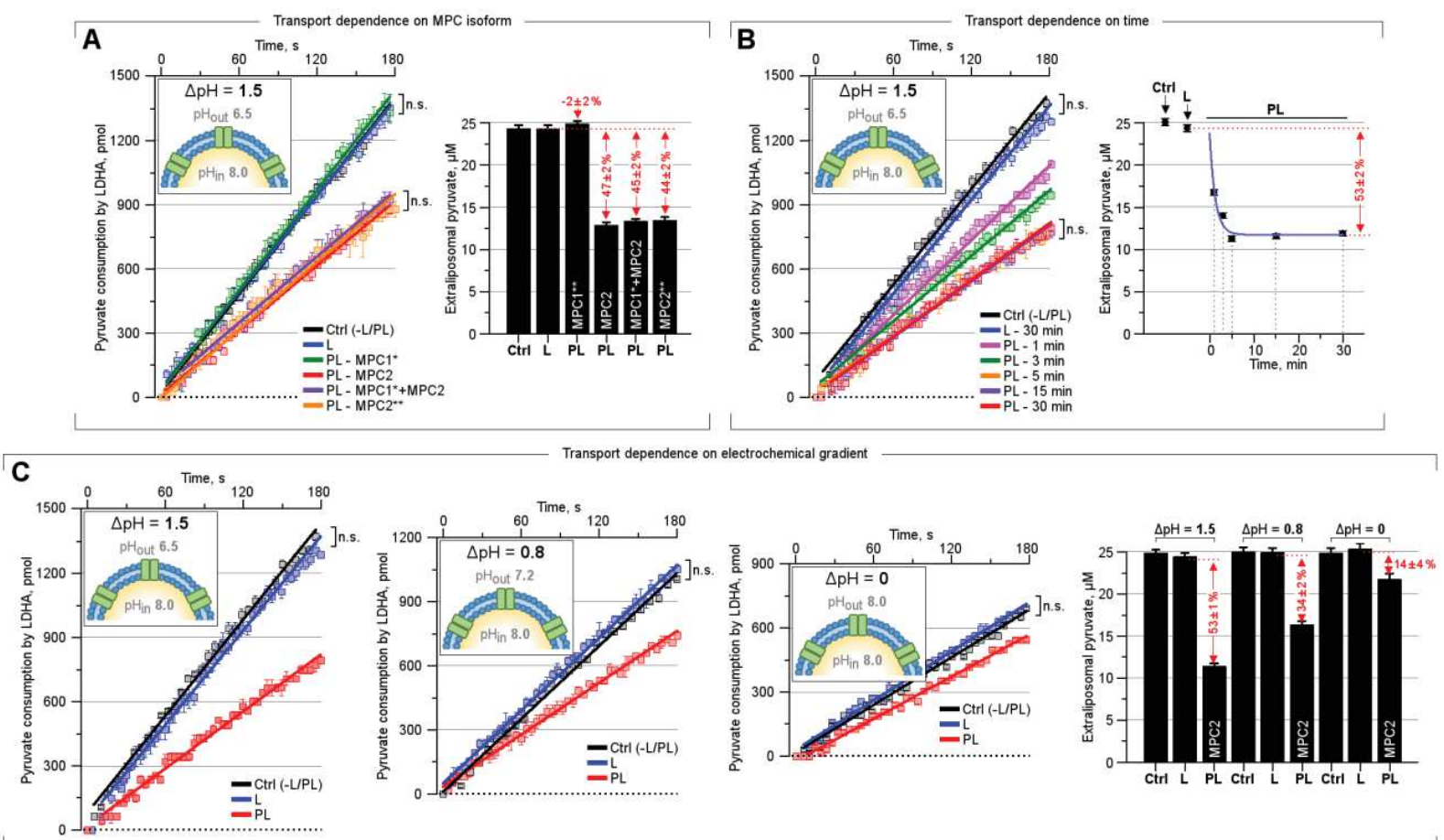
FIGURE 3.
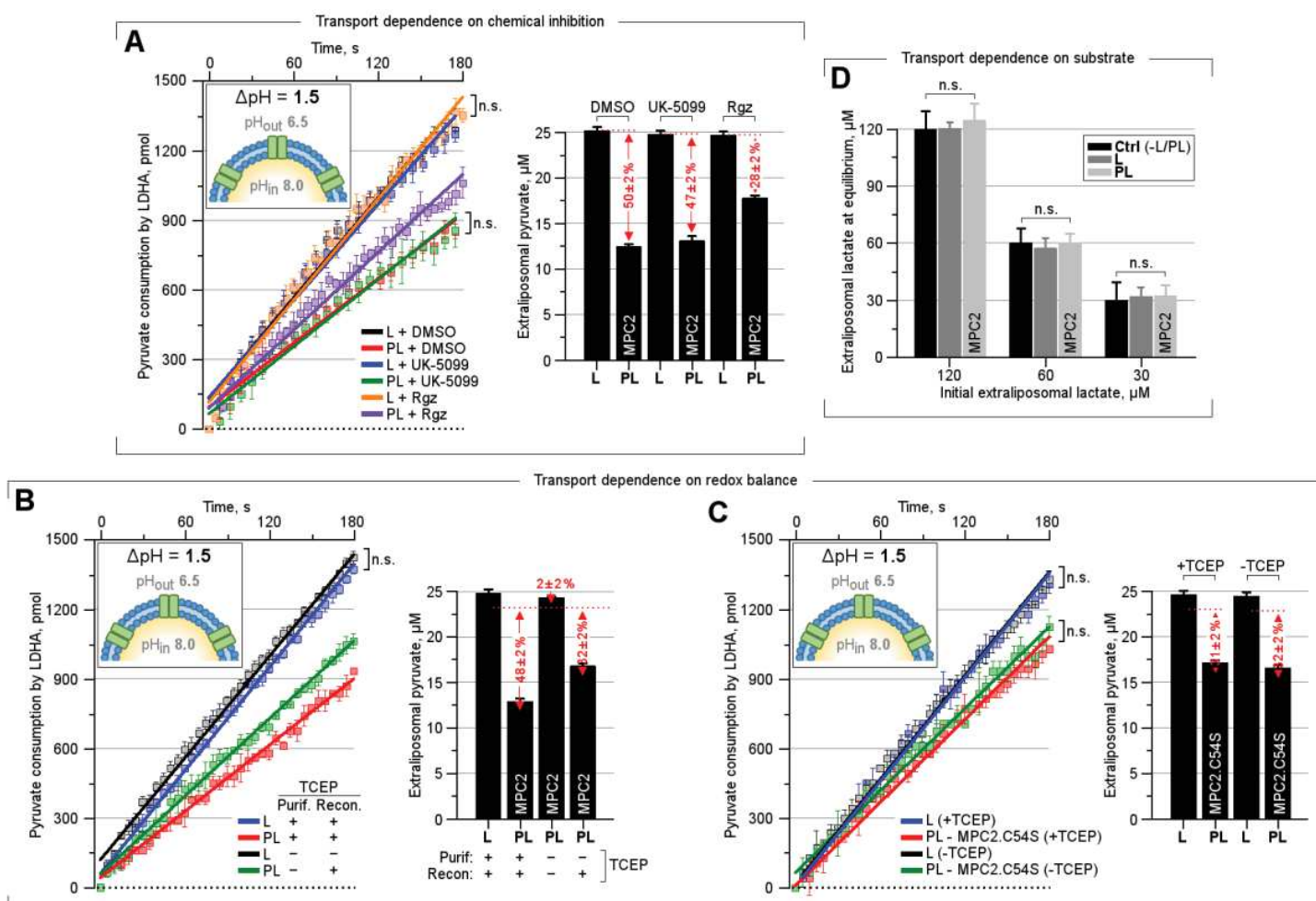
FIGURE 4.
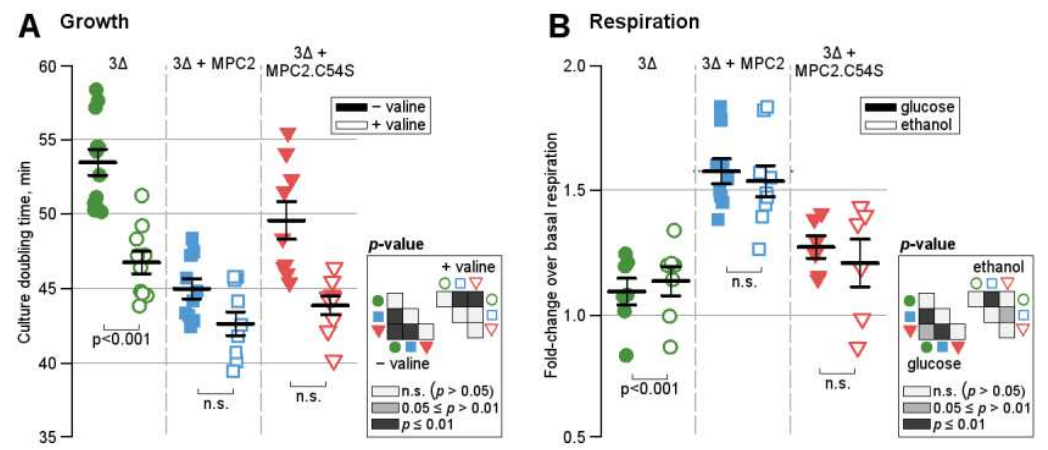
FIGURE 5.
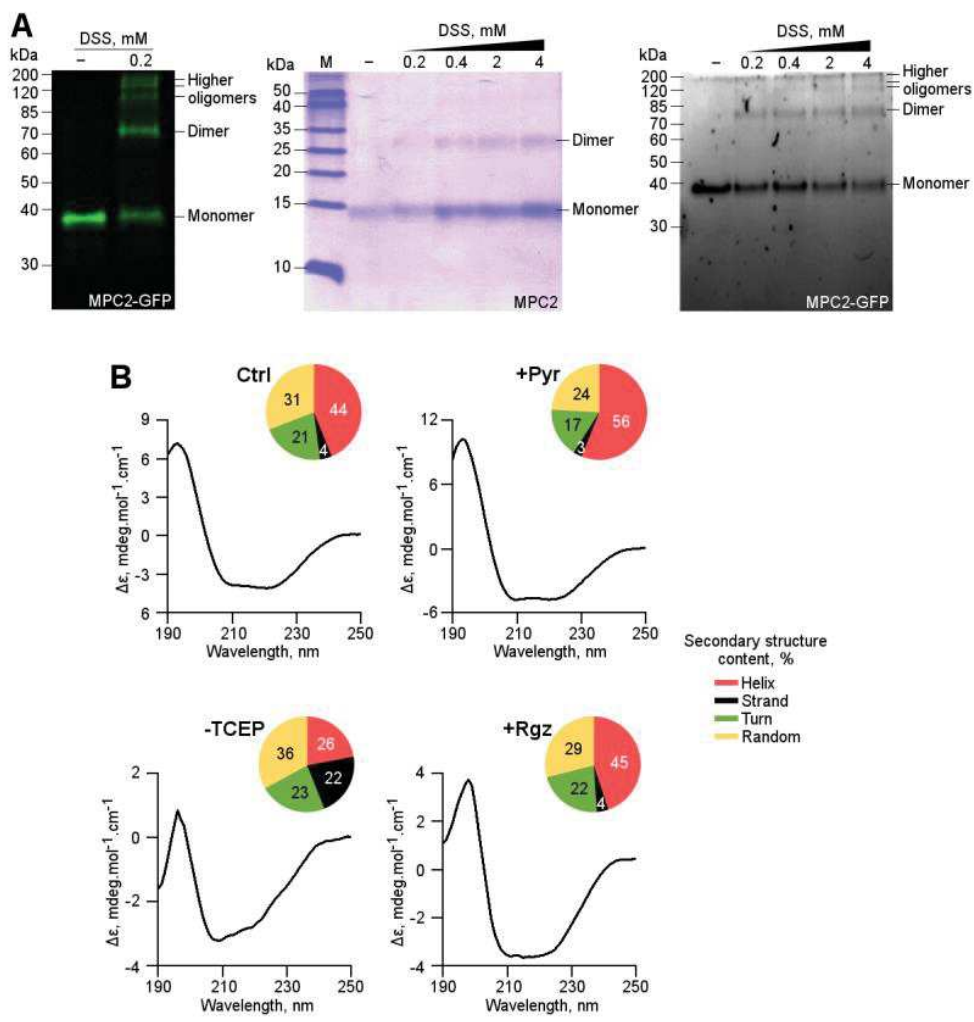

Secondary structure 